Flavia Igliori Gonsales

\title{
A Cor no Branding: um estudo sobre design de marca e comunicação visual estratégica
}

Programa de Pós-Graduação em Ciências da Comunicação da ECA-USP Área de concentração II: Estudos Dos Meios e da Produção Mediática Linha de pesquisa: Consumo e Usos Midiáticos nas Práticas Sociais 

Flavia Igliori Gonsales

\section{A Cor no Branding: \\ um estudo sobre design de marca e comunicação visual estratégica}

Tese apresentada ao Programa de Pós-Graduação em Ciências da Comunicação da Escola de Comunicações e

Artes da Universidade de São Paulo, como parte dos requisitos para a obtenção do título de Doutora em Ciências da Comunicação.

Área de Concentração II: Estudo dos Meios e da Produção Mediática

Linha de pesquisa: Consumo e Usos Midiáticos nas Práticas Sociais

Orientadora: Profa. Dra. Sandra Maria Ribeiro de Souza 
Autorizo a reprodução e divulgação total ou parcial deste trabalho, por qualquer meio convencional ou eletrônico, para fins de estudo e pesquisa, desde que citada a fonte.

Gonsales, Flavia Igliori

A Cor no Branding: um estudo sobre design de marca e comunicação visual estratégica / Flavia Igliori Gonsales. -São Paulo: F. I. Gonsales, 2018.

214 p.: il.

Tese (Doutorado) - Programa de Pós-Graduação em Ciências da Comunicação - Escola de Comunicações e Artes / Universidade de São Paulo.

Orientadora: Sandra Maria Ribeiro de Souza Bibliografia

1. Cor 2. Branding 3. Design de marca 4. Comunicação estratégica visual 5. Semiótica I. Souza, Sandra Maria Ribeiro de II. Título.

CDD 21.ed. - 302.2

Elaborado por Sarah Lorenzon Ferreira - CRB-8/6888 
Gonsales, Flavia Igliori.

A Cor no Branding: um estudo sobre design de marca e comunicação visual estratégica.

Tese apresentada à Escola de Comunicações e Artes da Universidade de São Paulo para obtenção do título de Doutora em Ciências da Comunicação.

Aprovada em:

\section{Banca Examinadora:}

1. $\operatorname{Prof}(\mathrm{a})$. Dr.(a):

Instituição: Julgamento:

Assinatura:

2. $\operatorname{Prof}(\mathrm{a}) . \operatorname{Dr} .(\mathrm{a})$ :

Instituição: Julgamento:

Assinatura:

3. $\operatorname{Prof}(a)$. Dr.(a):

Instituição: Julgamento:

Assinatura:

4. Prof(a). Dr.(a):

Instituição: Julgamento:

Assinatura:

5. $\operatorname{Prof}(a)$. Dr.(a):

Instituição: Julgamento:

Assinatura:

6. $\operatorname{Prof}(a)$. Dr.(a):

Instituição: Julgamento:

Assinatura: 



\section{Dedicatória}

A Thereza e Gladys, Martina, Neyde e Rosalina,

Fernanda e Paula: as mulheres da minha vida. 



\section{Agradecimentos}

À Profa. Dra. Sandra Souza, por me acolher e orientar. Você me reabriu as portas da academia, acreditou nos meus projetos e sonhos.

À Profa. Dra. Élide Monzeglio (in memorium), minha eterna mestra das cores.

À USP, onde obtive minha graduação, mestrado e, agora, defendo meu doutorado. Sou uma privilegiada em ter acesso ao ensino superior gratuito e de qualidade em um país extremamente desigual e injusto socialmente: que eu possa retornar, de algum modo, os recursos que me foram concedidos. À CAPES (Coordenação de Aperfeiçoamento de Pessoal de Nível Superior) pela concessão da bolsa de doutorado que viabilizou esta pesquisa. À Comissão Fulbright e, novamente, à CAPES, pela bolsa-prêmio de doutorado sanduíche, por meio da qual tive a incrível experiência de pesquisadora visitante no Lundquist College of Business, University of Oregon, USA. Thank you Aparna Sundar, Assistant Professor of Marketing, for accepting me with open arms.

Aos professores e funcionários do Programa de Pós-Graduação em Ciências da Comunicação da USP, em especial ao Prof. Dr. Eneus Trindade pelos ensinamentos e indicações nas disciplinas e na qualificação, e por todo o apoio durante sua gestão como Coordenador do PPGCOM/USP.

Aos amigos do PPGCOM que fizeram o meu doutorado mais proveitoso e divertido: Alhen ("faça a prova, mulher, faça a prova"), Silvio (que, além de tudo, me apresentou a Sandra), Lívia (rica, porque sabe viver), Cinira, Rosana, Diogo, Cris, Janiene, Bruno, Rafael. Sem vocês, não seria tão legal.

Aos meus pais, Gladys e Francisco, que incentivaram e investiram em meus estudos, desde sempre. Cheguei até aqui, e foi graças a vocês.

Ao Luis, professor, doutor e cúmplice. Sonhamos e realizamos juntos, de perto e de longe... a vida fica mais colorida com você, meu amor.

Obrigada. 



\section{Observações Iniciais}

Nos múltiplos campos de estudo desta pesquisa, vários dos termos utilizados são originais da língua inglesa. A Academia Brasileira de Letras recomenda que vocábulos ou expressões pertencentes a outro idioma devem vir entre aspas, ou em negrito, itálico ou outro sinal indicador. Porém, vários termos estrangeiros já foram incorporados à língua portuguesa na sua forma original e são usados sem alteração por importantes instituições brasileiras, como o Ministério da Educação ${ }^{1}$ e o Senado Federal brasileiro. Este último possui um Manual de Redação $^{2}$ disponível para consulta pública, onde demostra as palavras que são usadas pelo Senado sem grafia diferenciada. Alguns dos termos são utilizados com frequência neste relatório e serão grafados sem itálico (o diferenciador usado nos demais casos de estrangeirismo). Os termos são: design, designer, marketing, hardware, software, download, site, ranking e status. Além desses, o termo branding, cada vez mais utilizado no Brasil, também não será destacado.

Esta tese segue a padronização atualizada, em 2016, do documento "Diretrizes para apresentação de dissertações e teses da USP" - Sistema APA (American Psychological Association), disponível em < http://dx.doi.org/10.11606/9788573140576>.

\footnotetext{
${ }^{1}$ Os cursos de Design e de Marketing, por exemplo, são grafados sem itálico ou qualquer outra alteração, no site do Ministério. Disponível em < http://emec.mec.gov.br >. Acesso em 5 fev. 2016.

2 Manual que aborda a comunicação legislativa tal como é desempenhada pela Secretaria de Comunicação Social do Senado (Secom), para que seja referência em comunicação pública. Disponível em < www12.senado.leg.br/manualdecomunicacao/redacao-e-estilo/estilo/estrangeirismo > Acesso em 5 fev. 2016.
} 



\section{Resumo}

Gonsales, Flavia I. (2018). A Cor no Branding: um estudo sobre design de marca e comunicação visual estratégica. (Tese de Doutorado). Escola de Comunicações e Artes, Universidade de São Paulo, São Paulo.

Esta tese investiga a relação simbólica entre cor e marca, manifestada na comunicação visual estratégica marcária, e os vínculos de sentido que (co)produz junto aos públicos. Os objetivos são: identificar, analisar e classificar os modos em que as cores significam marcas (os potenciais efeitos da cor sobre os indivíduos-consumidores) e os usos estratégicos da cor, pelas marcas (as funções para as quais as marcas utilizam as cores) e, relacionando os modos e os usos, propor uma tipologia dos discursos cromáticos de marca, inspirada na tipologia semiótica do discurso, de Charles W. Morris (1946). A literatura transdisciplinar acadêmica e de prática de mercado foi combinada com os achados da pesquisa de campo - entrevistas em profundidade (com especialistas em comunicação, gestão e design de marcas), visitas de observação e coleta de artefatos físicos e digitais. Foram delimitados cinco modos da cor significar uma marca (atentivo, designativo, apreciativo, prescritivo e transformativo) e quatro principais usos que as marcas fazem das cores (informativo, avaliativo, incitivo e sistêmico). Ao final, foram distinguidos e exemplificados 13 tipos de discursos cromáticos de marca, conforme o modo e o uso proeminentes, que se revelaram interdependentes e não excludentes.

Palavras-chave: Cor. Branding. Design de marca. Comunicação estratégica visual. Semiótica. 



\section{Abstract}

Gonsales, Flavia I. (2018). Color Branding: a study on brand design and strategic visual communication (Doctoral Thesis). Escola de Comunicações e Artes, Universidade de São Paulo, São Paulo.

This thesis investigates the symbolic relationship between colors and brands, manifested in strategic visual communication, and the signification it (co)produces with the audience. The research purposes are to identify, analyze and classify the modes in which colors signify brands (the potential effects of color on consumers) and the strategic usages of color by brands (the purposes for which brands use colors) and, relating the modes and the uses, to propose a typology of brand chromatic discourses, inspired in the semiotic typology of discourse, by Charles W. Morris (1946). The transdisciplinary academic and industry literature was combined with the field research findings - from in-depth interviews (with brand communicators, managers, and designers), participant observations, and physical and digital artifacts collection. Five color modes of signifying a brand (attentive, designative, appraisive, prescriptive and transformative) and four primary color usages by brands (informative, valuative, incitive and systemic) are distinguished. Finally, 13 types of brand chromatic discourse, interdependent and non-exclusive, are delineated and exemplified, according to their dominant signification and use.

Keywords: Color. Branding. Brand design. Strategic visual communication. Semiotics. 



\section{Lista de Figuras}

Figura 1.1: "Você sabe pela cor, você sabe de cor quem é feito pra você", sem nome ou logo. ....28

Figura 1.2: Bumbódromo, embalagens e fachada de agência: tudo em vermelho e em azul.........28

Figura 1.3: Propagandas do iMac G3 da Apple, versão (a) de 1998 e (b) de 1999.......................29

Figura 1.4: A apresentadora Ellen DeGeneres criticou a "Bic para Elas" em seu programa de auditório.

Figura 1.5: O espectro eletromagnético, em ordem crescente de comprimento de onda. ..............38

Figura 1.6: O círculo cromático de Newton, de 1704.

Figura 1.7: (a) Sistema aditivo (RGB) em simulação das luzes-cores primárias sobre fundo preto; (b) Sistema subtrativo (CMY), com as três cores primarias sobre fundo branco.

Figura 1.8: As principais estruturas do olho humano (representado em corte).

Figura 1.9: As três dimensões da cor: (a) matiz, organizado em um círculo cromático, luminosidade (eixo vertical) e chroma (eixo horizontal) - do matiz (b) vermelho e (c) azul.

Figura 2.1: Os "significado das cores" em (a) um blog de design expondo o efeito das cores no consumidor, e (b) site da Valisere, sobre a cor ideal da calcinha, para o reveillon 2016.

Figura 2.2: Os diferentes efeitos da combinação do millennial pink, a cor da moda de 2017, com

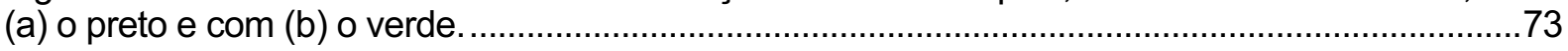

Figura 2.3: Logotipos dos cinco bancos de varejo do Brasil com atuação nacional..........................76

Figura 2.4: As cores designadoras da marca Vivo. ...................................................................7

Figura 2.5: (a) Antigos (2011) e (b) novos (2016) logotipos da Oi...................................................77

Figura 2.6: O verde como designador de avelã na categoria chocolate, na Europa.........................78

Figura 2.7: Interação cromática designando (a) o portfólio de quatro submarcas, até 2016; e (b) um novo portfólio com uma marca-mãe e quatro versões de adoçante. .......................................80

Figura 2.8:(a) Latas das versões Clássica, Diet e Zero; (b) Latas Artic Home, versão Clássica.....80

Figura 2.9: As "viciadas" em esmalte exibem suas coleções e unhas em blogs e redes sociais....93

Figura 2.10: O vermelho como signo que designa, aprecia e prescreve a Louboutin. ...................94

Figura 2.11: Tutoriais sobre como pintar as solas à la Louboutin..................................................95

Figura 2.12: Embalagem e cenas do filme de lançamento da Pepsi Crystal................................100

Figura 2.13: As embalagens e o ketchup colorido da Heinz. ...................................................100

Figura 2.14: Site (a) antes e (b) depois da alteração; Telas do (c) Instagram e (d) WhatsApp....101

Figura 3.1: A cor laranja permeia as manifestações visuais e identifica o Itaú.

Figura 3.2: Identificação visual da Nubank no (a) cartão de crédito; (b) site; (c) Facebook; (d)

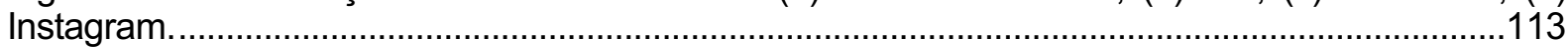

Figura 3.3: Propostas de logos responsivos para a Coca-Cola e Heineken.................................113

Figura 3.4: Latinhas das marcas de cerveja da (a) Ambev e da (b) Itaipava..................................115

Figura 3.5: Escarpin da Louboutin e sandálias da YSL, coleção Tribute Patent Leather. .............115

Figura 3.6: Menino e menina com seus brinquedos e roupas, rosas e azuis. ...............................118

Figura 3.7: Desde 1845, a Tiffany utiliza seu azul para construir associações entre a cor e amor, casamento, sofisticação, conceitos positivos no contexto da marca.............................................120

Figura 3.8: A volt (a) nos pés do vencedor e finalistas (b) dos 5mil metros em Londres, 2012 ....121

Figura 3.9: Anúncio digital da Gol e anúncio impresso da Azul, provocando-se mutualmente.....122

Figura 3.10: Exemplos de logotipos alterados na cor (a) no Twitter e (b) no Facebook. ..............123 
Figura 3.11: (a) Logotipo da BP e (b) sátiras visuais feitas após o vazamento de óleo. 124

Figura 3.12: (a, b) KFC e Campbell's usam a cor rosa para comunicar apoio à luta contra o câncer de mama; (c, d) Reações negativas da sociedade contra o pinkwashing. 125

Figura 3.13: Postagens de um vitrinista/vendedor da Glassybaby, exibindo (a) variedade de cores; (b) uma consumidora que encontrou sua cor preferida; (c) um arranjo cromático especial de Natal. 129

Figura 3.14: Os consumidores escolhem as cores das pastilhas M\&Ms na loja conceito e no site. 134 Figura 3.15: (a) Edição especial da Copa do Mundo do Brasil, e (b) edição limitada de 2012......134

Figura 3.16: (a) Lançamento e primeiras extensões da marca Dove no Brasil (1992-2002).........138

Figura 3.17: Algumas das ofertas atuais da Dove, o branco em combinação com várias cores. .139

Figura 3.18: Extensões da Dove, em sub-marcas: (a) Dove men + Care; (b) Baby Dove. ...........140

Figura 3.19: Extensões da Louboutin: bolsa, batom, chaveiro, lápis de olho e esmaltes. .............141

Figura 3.20: Pirâmide de segmentação do Itaú, organizada com o auxílio da cor. .........................142

Figura 3.21: Portfólio de marcas majoritariamente endossadas da Danone, no Brasil..................142

Figura 3.22: Portfólio de marcas independentes da P\&G, no Brasil............................................143

Figura 3.23: (a) Logotipo da marca-mãe nas cores corporativas vermelho, branco e azul; (b) Fachada com do Carrefour Express, em laranja; (c) Fachada do Carrefour Bairro, em verde. ....144 Figura 3.24: As cores organizando, nas latas (a) regulares e (b) promocionais da Coca-Cola.....145

Discurso (1) da Cor-Assinatura: Tiffany, em discurso designativo-informativo...............................151

Discurso (2) da Cor-Mito: M\&M's, em discurso apreciativo-informativo. ........................................153

Discurso (3) do Manual-da-Cor: Heineken, em discurso prescritivo-informativo. ............................155

Discurso (4) da Cor-Disruptiva: Renova, em discurso transformativo-informativo. ........................158

Discurso (5) do Arco-Íris: Telstra, em discurso designativo-avaliativo..........................................161

Discurso (6) da Cor-Alegoria: Skol, em discurso apreciativo-avaliativo. ........................................163

Discurso (7) da Cor-do-Ano: Pantone, em discurso prescritivo-avaliativo. ...................................165

Discurso (8) da Cor-Dialógica: KFC, em discurso transformativo-avaliativo...................................167

Discurso (9) da Cor-Código: Coca-Cola, em discurso designativo-incitivo. ..................................171

Discurso (10) da Cor-da-Moda: Glamurama e Impala, em discurso apreciativo-incitivo. ...............173

Discurso (11) da Cor-Mania: Chandon, em discurso prescritivo-incitivo. ......................................176

Discurso (12) da Cor-Criação: Skype, em discurso transformativo-incitivo. ....................................178

Discurso (13) da Cor-Estrutura: American Airlines, em discurso multimodal sistêmico.................183 


\section{Lista de Quadros e Tabela}

Quadro 1.1: Os principais tipos de discurso, segundo Morris.

Quadro 1.2: Entrelaçamento do teórico-experimental com o empírico-interpretativo, na tese. .......59

Quadro 1.3: Os principais tipos de discursos cromáticos de marca.

Quadro 2.1: Questões de pesquisa sobre os modos de significação das cores. .............................67

Quadro 2.2: Proposição dos modos das cores significarem marcas. ...........................................102

Quadro 2.3: Os três principais modos de significação Morrisianos comparados com vários modelos de hierarquia de respostas do consumidor, relativamente contemporâneos a Morris....105

Quadro 3.1: Questões de pesquisa sobre os modos de significação das cores. 107

Quadro 3.2: Proposição dos usos do signo-cor pelas marcas, com benefícios e riscos.

Quadro 4.1: Os principais tipos de discursos semióticos, segundo Morris. 147

Quadro 4.2: Os principais tipos de discursos cromáticos das marcas. 148

Quadro 4.3: Os quatro tipos de discursos voltados para a identidade de marca. 150

Quadro 4.4: Os quatro tipos de discursos voltados para a preferência de marca. 159

Quadro 4.5: Os quatro tipos de discursos voltados ao engajameto do público com a marca.......169

Quadro 4.6: O discurso cromático sistêmico, abarcando os quatro modos de significação 180

Tabela 1.1: Visão geral do perfil dos entrevistados. 62 



\section{Sumário}

1 Introdução à tese ......................................... 27

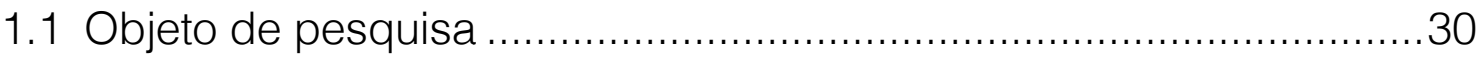

1.1.1 A Comunicação visual estratégica de marca ..........................................................30

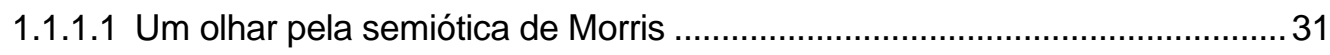

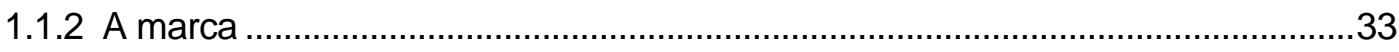

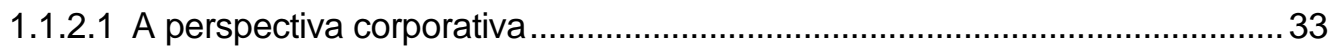

1.1.2.2 A perspectiva do consumidor ............................................................... 34

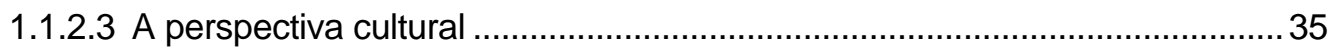

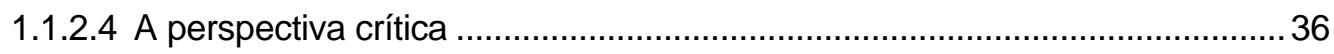

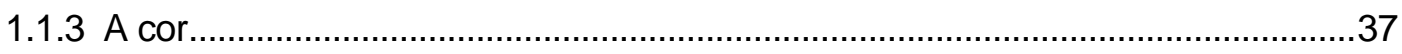

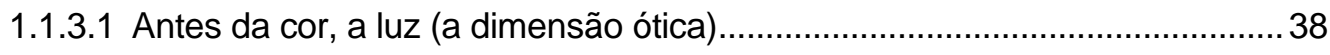

1.1.3.2 O aparato visual humano (a dimensão anatômica) ...................................... 41

1.1.3.3 A cor está na sua mente (a dimensão psicofísiológica)................................ 42

1.1.3.4 O entendimento moderno de cor ............................................................... 44

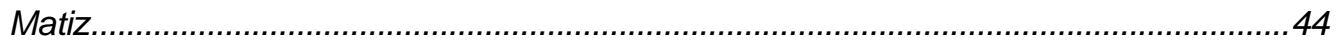

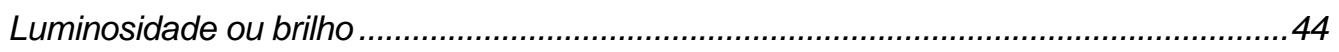

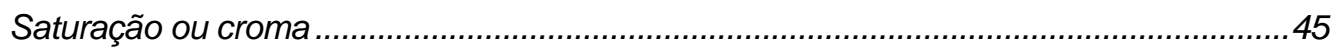

1.2 Problema, hipótese e justificativa ........................................ 47

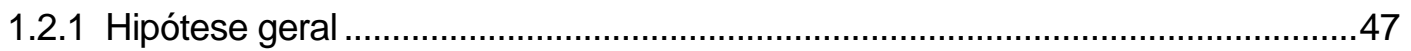

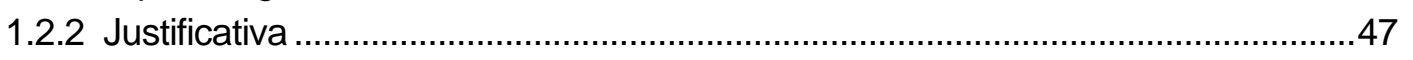

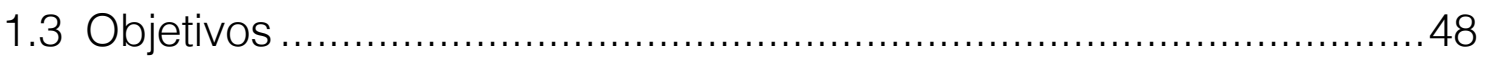

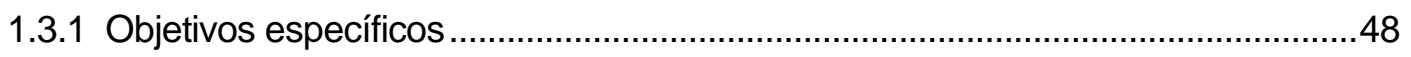

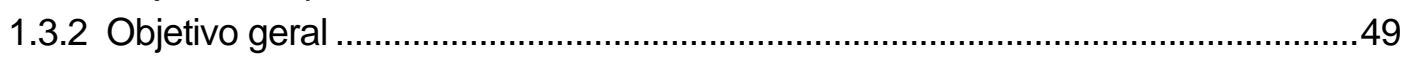

1.4 Abordagem teórico-metodológica ................................... 49

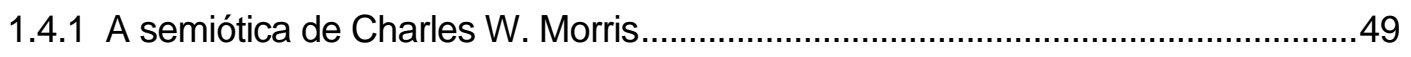

1.4.1.1 A teoria geral do signo e as dimensões da semiose..................................50

A sintaxe: o estudo da dimensão sintática da semiose .................................................

A semântica: o estudo da dimensão semântica da semiose ...........................................51

A pragmática: o estudo da dimensão pragmática da semiose............................................52

1.4.1.2 O eixo-estruturante da tese: a tipologia dos discursos sígnicos....................52

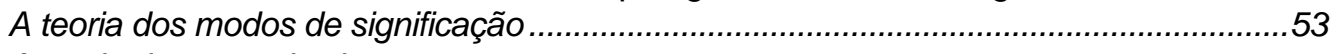

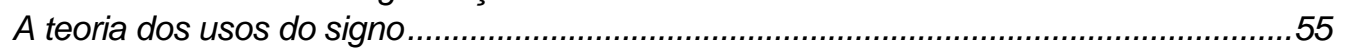

Os 16 principais tipos de discursos do cotidiano ........................................................56

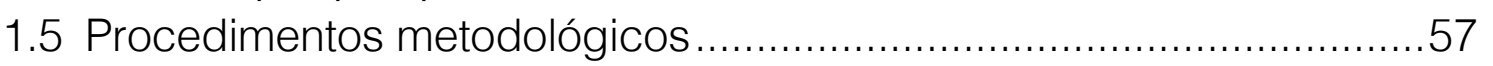

1.5.1 Entrelaçamento da base teórica com o trabalho de campo..................................58

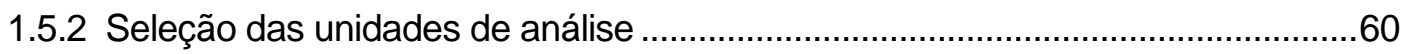

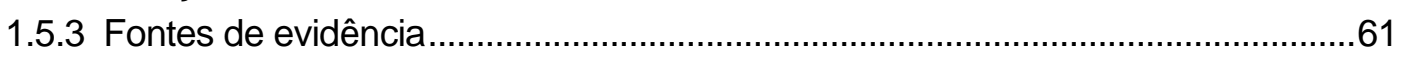

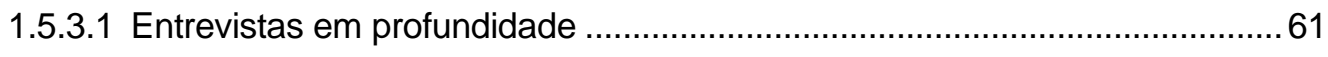

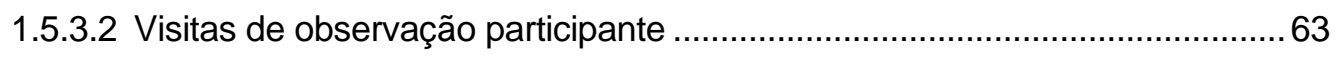

1.5.3.3 Coleta de artefatos físicos e documentação fotográfica ............................... 63

1.5.4 Análise dos dados e resultado final ...............................................................64 


\section{Modos de significação da cor para a marca ........ 67}

2.1 A cor localiza uma marca em um tempo/espaço específico?............70

Proposição 1: a cor significa a marca no modo atentivo (attentive mode) .....................70

2.2 A cor caracteriza uma marca? ...................................... 74

Proposição 2: a cor significa a marca no modo designativo (designative mode) ..............74

O signo-cor como designador-de-marca ............................................................. 75

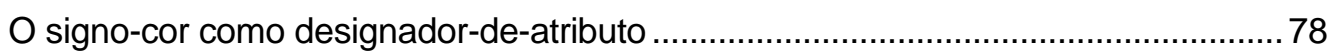

A interação entre as cores, designando a marca e seu atributos................................79

2.3 A cor induz apreciações em relação a uma marca? ....................... 81

Proposição 3: a cor significa a marca no modo apreciativo (appraisive mode) ..............82

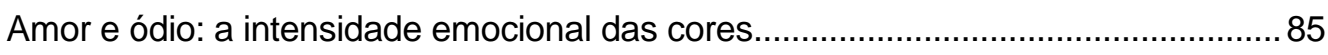

Positivo ou negativo? Valências e ambiguidades culturalmente construídas ..................86 86

2.4 A cor provoca uma ação em relação a uma marca?......................89

Proposição 4: a cor significa a marca no modo prescritivo (prescriptive mode) .............89

O ritual e o cotidiano da cor na prescrição do consumo marcário................................92

2.5 A cor altera disposições prévias sobre uma marca? .......................96

Proposição 5: a cor significa a marca no modo transformativo (transformative mode) ........97

Mudança e disrupção: a cor que inova................................................................98

2.6 Síntese dos modos de significação do signo-cor ....................... 102

Modos de significação e os estudos atuais do comportamento humano ................103

\section{Usos da cor como signo de marca .................. 107}

3.1 Por que e como a cor é usada para informar sobre a marca? .........108

Proposição 6: o adequado uso informativo da cor promove a identificação da marca108

Consistência: condição essencial para a cor identificar uma marca ........................109

Diferenciação: o uso exclusivo da cor, pela marca ................................................111

Confusão e imitação: a cor informando falsamente sobre a marca .........................113

Depreciação: o excesso cromático que desvaloriza a marca..................................116

3.2 Por que e como a cor é usada para induzir um status preferencial pela marca? 117

Proposição 7: o adequado uso avaliativo da cor promove a preferência pela marca .117

Originalidade: para marcas únicas, associações cromáticas únicas ......................119

Relevância: cores para avaliar positivamente, no aqui e agora ...............................123

Desconfiança e rejeição: o uso hipócrita das cores ..........................................123

3.3 Por que e como a cor é usada para incitar ações para a marca? ...126

Proposição 8: o adequado uso incitivo da cor provoca o engajamento de marca.......126

Versatilidade: variedade de cores, tudo para todos ..............................................128

Normatização: cores prescritas e o consumo conspícuo ........................................130

Cocriação: o engajamento criando valor, pela cor .............................................133

Inércia e boicote: a não persuasão e a persuasão cromática inadequada...............135 
3.4 Por que e como a cor é usada para organizar prévias disposições sobre

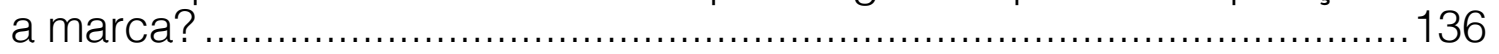

Proposição 9: o adequado uso sistêmico da cor organiza visualmente a marca ........136

Categorização: a cor apoiando as extensões de marca........................................... 137

Classificação: a cor expressando a arquitetura do portfólio de marcas ....................140

Bagunça: quando a cor desorganiza a marca.........................................................144

3.5 Síntese dos usos do signo-cor pelas marcas ................................145

\section{Tipologia semiótica dos discursos cromáticos de} marca ......................................................... 147

4.1 Os discursos cromáticos para identidade de marca ......................150 A Cor-Assinatura (discurso cromático designativo-informativo) ...................................150

A Cor-Mito (discurso cromático apreciativo-informativo) .............................................152

O Manual-da-Cor (discurso cromático prescritivo-informativo) .....................................154

A Cor-Disruptiva (discurso cromático transformativo-informativo) ...............................157

4.2 Os discursos cromáticos para preferência de marca ......................159

O Arco-Íris (discurso cromático designativo-avaliativo) ................................................160

A Cor-Alegoria (discurso cromático apreciativo-avaliativo) ........................................162

A Cor-do-Ano (discurso cromático prescritivo-avaliativo) ...........................................164

A Cor-Dialógica (discurso cromático transformativo-avaliativo) ...................................167

4.3 Os discursos cromáticos para engajamento de marca...................169

A Cor-Código (discurso cromático designativo-incitivo) …………..............................170

A Cor-da-Moda (discurso cromático apreciativo-incitivo) ..........................................172

A Cor-Mania (discurso cromático prescritivo-incitivo) …………………………….....174

A Cor-Criação (discurso cromático transformativo-incitivo) .........................................177

4.4 O discurso cromático para organizar as marcas............................180

O discurso cosmológico Morrisiano (designativo-sistêmico) .....................................181

O discurso crítico Morrisiano (apreciativo-sistêmico) ................................................ 181

O discurso propagandístico Morrisiano (prescritivo-sistêmico) ................................. 181

O discurso metafísico Morrisiano (formativo-sistêmico) .............................................181

A Cor-Estrutura (discurso cromático multimodal sistêmico) .........................................182

5 Considerações finais.......................................... 185

Referências bibliográficas .................................. 187

Apêndices ........................................................ 209

Apêndice A: Roteiro das entrevistas em profundidade, em inglês.................................209

Apêndice B: Roteiro das entrevistas em profundidade, em português..........................211

Apêndice C: Roteiro das visitas de observação participativa........................................213 

"Nossas cores são categorias abstratas sobre as quais a técnica não tem muita influência. Eu acho bom saber seus sentidos, porque eles condicionam nossos comportamentos e nossa maneira de pensar. Mas, uma vez que estamos conscientes de tudo o que implicam, podemos esquecê-los. Olhemos as cores como especialistas, mas saibamos também vivê-las com espontaneidade e uma certa inocência". ${ }^{3}$

Michel Pastoureau

\footnotetext{
${ }^{3}$ Nos couleurs sont des catégories abstraites sur lesquelles la technique n'a pas de prise. Je crois qu'il est bon de connaître leurs significations, car elles conditionnent nos comportements et notre manière de penser. Mais, une fois que l'on est conscient de tout ce dont elles sont chargées, on peut l'oublier. Regardons les couleurs en connaisseur, mais sachons aussi les vivre avec spontanéité et une certaine innocence. (Pastoureau \& Simonnet, 2005, pp. 124-125)
} 



\section{Introdução à tese}

Quantas marcas um indivíduo encontra por dia, do momento em que acorda até voltar a fechar seus olhos, para dormir? E cores, quantas é capaz de discernir, nessa jornada?

Os números impressionam na mesma grandeza em que variam. Especula-se que somos expostos, diariamente, a cerca de 4 mil a 10 mil mensagens de marca (Forbes Agency Concil, 2017). Outra fonte, mais "parcimoniosa", indicou que a caminho do trabalho, em uma viagem de 45 minutos de ônibus em Londres, uma pessoa foi exposta a 130 mensagens, mas se lembrou espontaneamente de apenas uma delas (Daily Mail, 2012). Quanto a cores, pesquisas demostram que o ser humano (de visão considerada normal) pode distinguir, idealmente, até 10 milhões de cores, embora as experiências cromáticas do mundo natural sejam, na prática, 30\% do limite máximo teórico. Ou seja, distinguimos cerca de 2.3 milhões de cores (Linhares, Pinto, \& Nascimento, 2008).

Mesmo nas previsões mais modestas, são muitas marcas e cores, diariamente. Ser exposto a elas não implica, porém, que o individuo as "percebeu" visualmente. E se percebeu, vai se lembrar? Reconheceu as marcas (que usam as cores)? Gostou? Fotografou? Postou? Comprou? Para os comunicadores, designers e gestores, a única resposta que interessa é "sim" e para obtê-la, a cor pode ser usada como recurso estratégico da comunicação visual de marca.

$\mathrm{Na}$ literatura acadêmica mercadológica, a cor é tratada majoritariamente como um elemento de identificação, um recurso estético que deve ser utilizado de maneira fixa, consistentemente, a partir do logotipo para os demais pontos-de-contato. É o caso do Itaú, da Louboutin, da Tiffany: o laranja, o vermelho e o azul-esverdeado, respectivamente, "significam" as marcas de modo quase autônomo (Figura 1.1). Esses exemplos foram a inspiração inicial desta tese - as cores como protagonistas da manifestação marcária.

A palavra "protagonista" tem origem na língua grega, protagonistes ( $\pi \rho \omega \tau \alpha \gamma \omega v \imath \sigma \tau \varepsilon ́ \varsigma)$, de proto (primeiro em importância) e agonistes (ator, competidor de uma agon, luta, batalha, jogo), aquele que "combate na primeira fila, que desempenha o papel principal em uma peça 


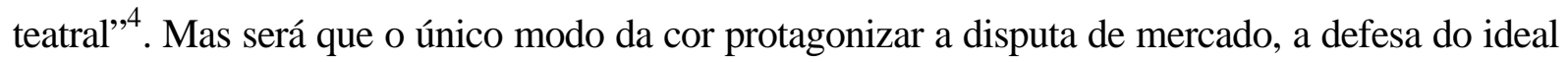
marcário, é ser aplicada imutavelmente, reiteradamente, ubiquamente?

Figura 1.1: "Você sabe pela cor, você sabe de cor quem é feito pra você", sem nome ou logo.
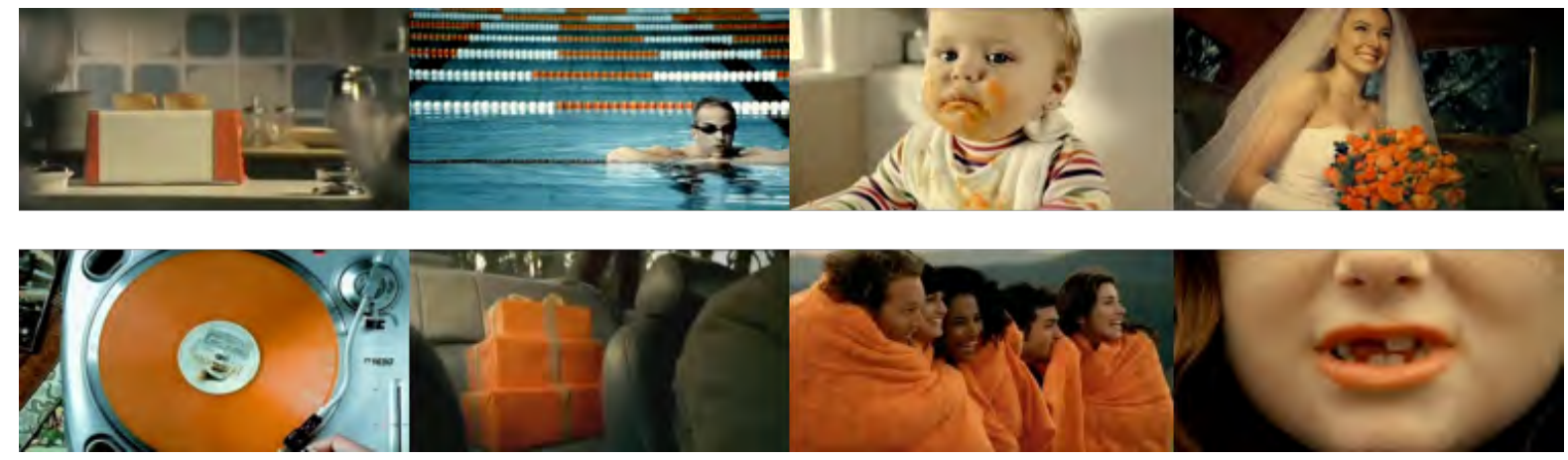

Fonte: Frames do filme "Inconfundível" (Itaú, 2006), criado pela agência África..

O que dizer da Coca-Cola e do Bradesco (Figura 1.2), que trocaram regionalmente o original vermelho protagonista pela cor azul? Patrocinadoras do festival folclórico de Parintins, essas marcas alteraram seus logos, propagandas, sinalização e embalagem para se adequarem à rivalidade entre o Boi Garantido (vermelho) e o Boi Caprichoso (azul). Na cidade amazonense, metade da população e dos turistas não consome marcas vermelhas, enquanto a outra não consome as azuis.

Figura 1.2: Bumbódromo, embalagens e fachada de agência: tudo em vermelho e em azul. (a)

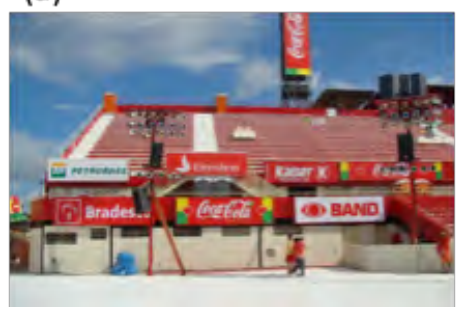

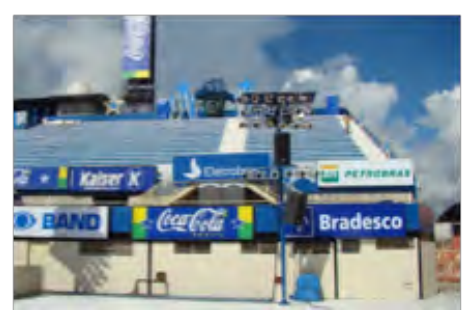

(b)

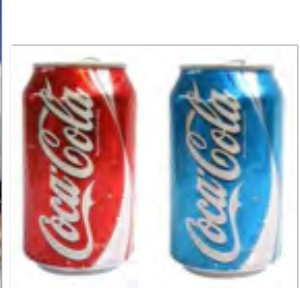

(b)

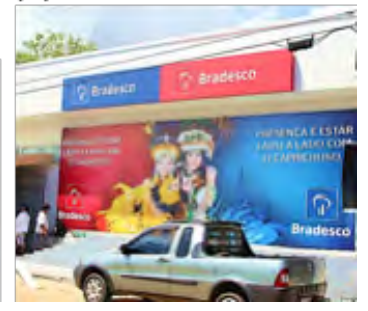

Fontes: (a) Portal No Amazonas é Assim (2013); (b) Portal iG (Dezan, 2010).

O que dizer da Apple que em 1998, uma época de computadores beges ou cinzas, lançou o iMac G3 em azul-esverdeado ${ }^{5}$ e, no ano seguinte, em outras cinco cores (de uva, limão, tangerina, mirtilo e morango)? A inovação da variedade cromática no produto (Figura 1.3) conquistaram o público, enquanto expressavam os valores centrais da marca: criatividade,

\footnotetext{
${ }^{4}$ Dicionário Português Oxford University Press (C 2012 Editora Objetiva. Versão eletrônica para Macintosh.

${ }^{5}$ A cor oficial é denominada "Bondi blue", azul da cor do mar de Bondi, praia de Sydney, Austrália.
} 
simplicidade e convivência (Kapferer, 2012, p. 252). Segundo Steve Jobs, "para a maioria dos consumidores, a cor é muito mais importante do que mega-hertz, gigabytes e outros jargões associados à compra de um PC típico” (Johnson, 1999).

Figura 1.3: Propagandas do iMac G3 da Apple, versão (a) de 1998 e (b) de 1999.

(a)

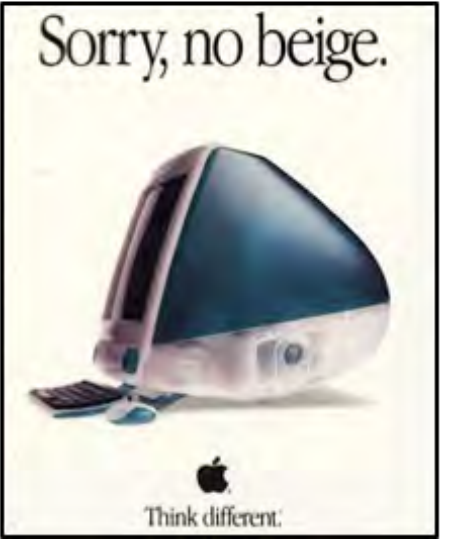

(b)

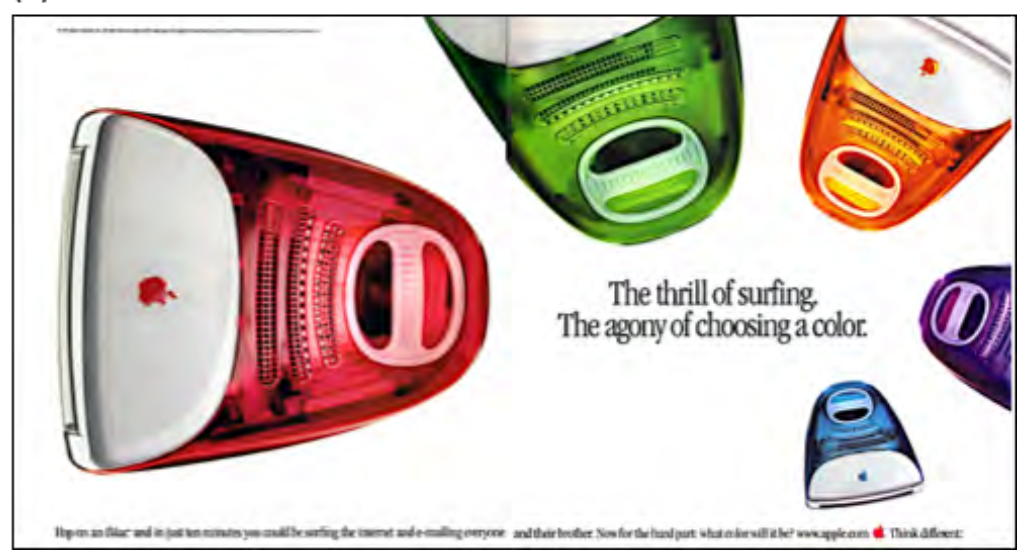

Fontes: (a) Blog Material Designs (2009); (b) Portal Webdesigner Depot (2009).

Muitas vezes pensada para ser a protagonista, a cor pode ser uma poderosa antagonista da manifestação marcária, como no caso da "Bic for Her" (Figura 1.4). Conforme a embalagem, uma "caneta elegante, desenhada somente para ela", mas que foi rejeitada por consumidoras (e celebridades) engajadas contra a pink tax ("taxa rosa"): o preço mais caro de um produto, pelo simples fato da versão ser posicionada para o público feminino - e frequentemente pintada de rosa.

Figura 1.4: A apresentadora Ellen DeGeneres criticou a "Bic para Elas" em seu programa de auditório.

(a)

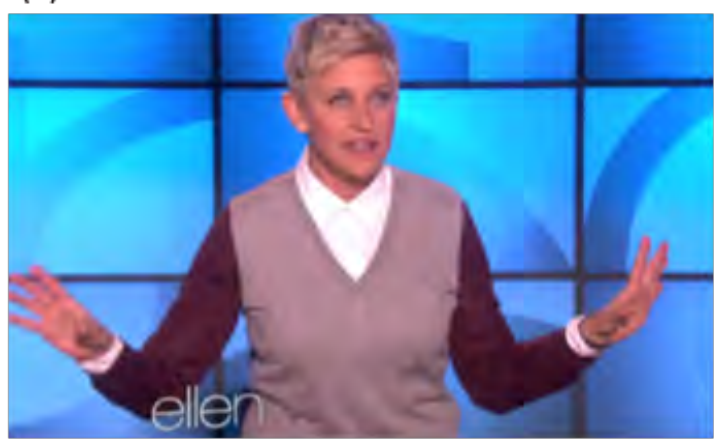

(b)

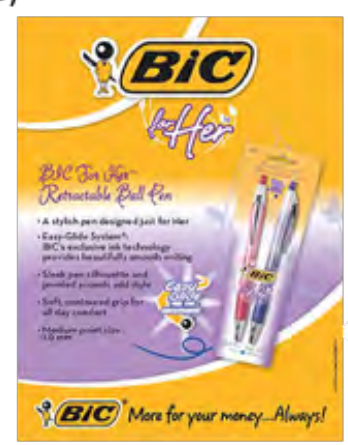

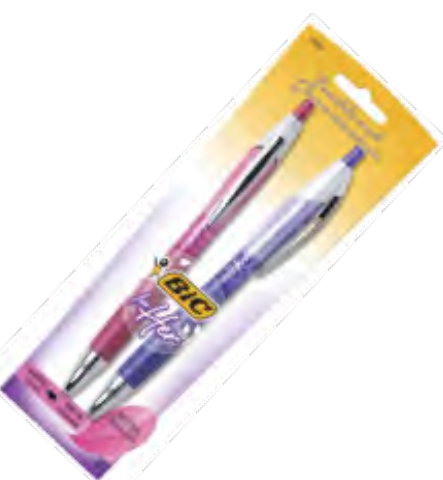

Fontes: (a) Programa The Ellen Show (2012); (b) Site de compras Amazon.com. Último acesso em 10/01/2018.

Você acredita? Nós temos usado canetas para homens durante todos esses anos! Arrggh. [A Bic for Her] vem nas cores de uma dama, rosa e roxo. Elas são canetas normais, exceto que são rosas e custam duas vezes mais. [...] A pior parte é que elas não vêm com 
instruções. Então, como eles esperam que eu saiba escrever com elas?.... É tão ridículo! (DeGeneres, 2012)

Fixa ou mutável, no longo ou no curto prazo, global ou localmente, no logotipo, no produto, na embalagem, na propaganda, nas redes sociais... em que modos a cor impacta os indivíduos-consumidores da sociedade contemporânea, do espetáculo (das imagens), da informação, conectada em rede? Como os comunicadores, designers e gestores, na era dos monitores de 16.7 milhões de cores, das TVs de 100 e smartphones de 4 polegadas, exploram a capacidade sígnica das cores?

\subsection{Objeto de pesquisa}

O objeto ampliado desta pesquisa é a relação simbólica entre cor e marca, manifestada na comunicação visual estratégica marcária, e os vínculos de sentido que (co)produz junto aos públicos, “consumidores visuais”. Especificamente, o objeto de estudo são os modos em que as cores significam marcas (modos de significação) e os usos estratégicos que as marcas fazem das cores (usos sígnicos) ao aplicá-las em seus pontos-decontato. Os conceitos básicos que integram o objeto de pesquisa são apresentados a seguir.

\subsubsection{A Comunicação visual estratégica de marca}

Ao investigar os modos e os usos da cor nas manifestações visuais de marca, esta tese se insere nos estudos da comunicação visual, subdivisão das ciências da comunicação considerada em expansão. Enraizada nas ciências sociais, a comunicação visual enfrenta suas questões de pesquisa por uma abordagem crítica, a fim de "explicar os processos de produção, distribuição e recepção", e os fenômenos visuais contemporâneos em seus contextos sociais, culturais, econômicos e políticos (Müller, 2007, p. 24). A comunicação visual é a "troca de informações, ideias, sentimentos e ordens” por meio de recursos visuais (S. Souza, 1995, p. 175), na qual, diferentemente da simples exibição, o produtor da mensagem/estímulo visual intenciona que "a audiência entenda pelo menos alguns dos significados pretendidos" (Kenney, 2010, p. 1).

Esses efeitos comunicativos pretendidos são, na tese, os objetivos almejados pelas marcas ao emitirem seus discursos visuais cromáticos por meio do logotipo, produto, embalagens, logos, produtos, uniformes, ambientação interna dos escritórios e das lojas, material de assessoria de imprensa, propaganda, etc. Assim, o presente trabalho também se insere no subcampo da comunicação organizacional: a visão abrangente da "comunicação nas e das organizações", que 
abarca a comunicação institucional, a interna, a administrativa e a mercadológica, sob uma filosofia da comunicação integrada e estratégica (Kunsch, 2009, pp. 79-80).

A natureza estratégica refere-se à função comunicacional de valorizar as pessoas e agregar valor às organizações, apoiando-as no cumprimento de sua missão e objetivos globais, fixando seus valores seguindo princípios éticos. Por integrada, entende-se que as ações comunicativas organizacionais devem incorporar "as demandas, os interesses da sociedade e as exigências dos públicos e da sociedade", sob um olhar holístico, não fragmentado" (Kunsch, 2014, p. 46).

Dentro do amplo espectro da comunicação organizacional, o foco da tese é a comunicação de marcas (de produto, serviço, empresa, organizações civis, grupo de ativistas, celebridade, pessoal [personal branding], cidades, estados, países [place branding], etc.), voltada para um público externo específico: o consumidor efetivo (e/ou comprador, usuário, cliente), em prospecção ou o aspiracional - que, ao desejar consumir, participa ativamente da produção de sentido das marcas (e das cores das marcas).

Além disso, o presente trabalho considera a intenção estratégica de influenciar seus públicos de interesse como a principal função da comunicação das organizações a ser investigada e, por isso, adota "comunicação visual estratégica" como definição do seu subcampo de pesquisa. Apesar das eventuais acepções negativas, limitantes ou contraditórias de "estratégica", o termo inclui a atuação das relações públicas, publicidade e marketing (e outros agentes organizacionais), as práticas participativas das partes interessadas (para além da organização emissora) e reforça a atenção crítica necessária sobre as relações de poder na comunicação (Hallahan, Holtzhausen, van Ruler, Verčič, \& Sriramesh, 2007).

\subsubsection{Um olhar pela semiótica de Morris}

Para responder às problematizações de pesquisa, a tese emprega o olhar da semiótica: uma doutrina transdisciplinar e multi-tradicional, que incorpora um amplo conjunto de conceitos, princípios e ferramentas para explicar a comunicação e a produção sentido, aplicadas em várias disciplinas, desde a zoosemiótica à semiótica do direito e do marketing (Mick, 1997, p. 252). São muitas as tradições de estudo dos signos, com percursos, visões metodológicas e aplicações distintas, sendo as três matrizes principais: a semiologia de Ferdinand Saussure, a semiótica de Charles Sanders Peirce e a semiótica da cultura, de origem russa (Trindade, 2006).

A semiótica utilizada aqui é a de Charles Williams Morris (1901-1979), um dos primeiros e dos mais notáveis a seguir a vertente Peirceana (Nöth, 1990, p. 40). Mais 
especificamente, o eixo teórico-metodológico da tese é a tipologia semiótica dos discursos cotidianos, que Morris (1946) apresentou no livro Signs, language and behavior, e que será detalhada mais adiante (na seção 1.4.1.2).

Nessa obra, para definir as teorias de modo, de uso sígnico e uma tipologia discursiva, Morris restringe o amplo conceito de comunicação para o "uso de signos a fim de estabelecer uma significação comum" (Morris, 1946, p. 118). O usuário do signo, que efetua a comunicação, é o comunicador (communicator), que neste trabalho é frequentemente referido como a própria entidade "marca", mas que, na realidade, são os gestores, comunicadores, designers, etc., contratados pela empresa que a detém. Ainda sobre os termos de Morris, o organismo impactado pelo processo sígnico é o "comunicado" (communicatee), na tese frequentemente denominado como indivíduo, consumidor, intérprete, stakeholders, ou públicos de interesse da marca.

Um ponto importante nessa obra Morrisiana, e adotado aqui pela pesquisadora, é a ideia de "adequação de comunicação": se a comunicação, em quaisquer dos modos ou usos sígnicos, estabelecer a significação intencionada pelo comunicador, ela foi adequada. Morris enfatiza que os intérpretes têm a tendência a responderem de uma ou outra maneira, conforme sua teoria propõe, mas se essa tendência irá tomar forma (ou não) depende de muitos fatores. Como por exemplo, as necessidades do indivíduo comunicado, a confiabilidade dos signos utilizados, a atitude de confiança ou de suspeição que o comunicador possui frente ao comunicado, entre outros aspectos. "O fato da comunicação ser estabelecida não assegura em nenhuma maneira automática que os propósitos, para os quais a comunicação foi efetuada, serão alcançados" (Morris, 1946, p. 119).

Aplicando a declaração de Morris para o estudo das cores e marcas, as manifestações visuais produzidas e difundidas, nas quais as cores são estrategicamente aplicadas, podem ou não atingir os objetivos desejados - e nesse aspecto serão, ou não, consideradas adequadas. A preferência de cores dos consumidores, a cor da moda atual, as cores da marca concorrente, a iluminação do supermercado, a imagem da marca na mente dos públicos de interesse são alguns dos inúmeros fatores que influenciam as respostas dos indivíduos às cores de uma marca, discutidas ao longo do trabalho. 


\subsubsection{A marca}

Para estudar a cor como signo marcário e como elemento da comunicação visual estratégica, a tese encara a marca sob um conceito alargado:

De um ponto de vista amplo, as marcas e o branding não são apenas ferramentas corporativas ou conceitos de marketing; eles representam objetos ideológicos, gerenciais e acadêmicos complexos. As marcas não são apenas mediadoras do significado cultural; elas se tornaram referentes ideológicos que moldam rituais culturais, atividades econômicas e normas sociais. ${ }^{6}$ (Schroeder, 2009, p. 124)

Nesse amplo olhar do fenômeno marcário, ainda que o "branding" seja aqui investigado principalmente nas pertinências do gerenciamento (perspectiva corporativa) e do consumo (perspectiva do consumidor), são incluídos também os aspectos socioculturais: a marca como cultura (perspectiva cultural) e as implicações éticas e políticas da lógica de marca (perspectiva crítica). Configura-se, assim, uma investigação abrangente das quatro perspectivas indissociáveis da marca, os “4 C’s do branding” (Schroeder, 2017).

\subsubsection{A perspectiva corporativa}

A perspectiva corporativa aborda a marca sob o ponto de vista estratégico, como um ativo intangível gerenciável, visando o lucro de quem a detém. Os conceitos fundamentais de identidade, imagem e patrimônio (equity) de marca são a base para o entendimento da essência e do valor financeiro marcário (Schroeder, 2017, p. 2). Na abordagem gerencial, a definição de uma identidade coerente e relevante para os públicos interessados é "pré-requisito essencial para uma gestão de marca eficiente" (Kapferer, 2012, p. 149), tornando-a forte, valiosa, capaz de enfrentar as "forças de mercado que enfatizam produtos não-diferenciados e a competição de preços" (Aaker \& Joachimsthaler, 2007, p. 49).

O grande desafio dos gestores de marcas é corporificar a faceta abstrata da identidade, tornar tangíveis os seus valores centrais para que sejam acessíveis aos sentidos humanos e que possam proporcionar experiências pertinentes aos seus stakeholders. Na literatura, essas manifestações identitárias são denominadas por diferentes termos, como por exemplo,

\footnotetext{
6 "From a broad viewpoint, brands and branding are not just corporate tools or marketing concepts; they represent complex ideological, managerial, and scholarly objects. Brands are not only mediators of cultural meaning; they themselves have become ideological referents that shape cultural rituals, economic activities, and social norms".
} 
elementos de marca (K. L. Keller, 1998), indicadores de marca (Aaker, 1998) ou fontes de identidade ou DNA da marca (Kapferer, 2012).

Os elementos da identidade, via de regra, são materializações centrais, verbais e visuais (e auditivas, etc.) da marca: nome, logotipo (e outros símbolos gráficos), o produto ou serviços em si (incluindo as lojas-conceito e demais ambientes proprietários, físicos ou virtuais), embalagem, mascote e personagem, propaganda (incluindo slogan e jingle), o domínio na internet $\left(\mathrm{URL}^{7}\right.$ e o site em si). Em uma concepção mais abrangedora e atualizada, os aplicativos (apps) e perfis nas redes sociais (Facebook, Instagram, Twitter, etc.) podem também ser pensados elementos da identidade - em muitos e cada vez mais frequentes casos, são os principais pontos-de-contato entre a marca e seus públicos.

Sob a estrutura teórica-metodológica da tese, os elementos de identidade são considerados os elementos sintáticos da marca, componentes básicos de sua manifestação, nos quais são aplicadas as cores, denominados como pontos-de-contato, materiais de identidade, expressão ou comunicação de marca. Os materiais são criados e produzidos por equipes internas ou externas, para cumprir funções estratégicas: gerar conhecimento (memorização, apreensão, identificação, diferenciação dos concorrentes), associações (remeter os públicos a sensações, atributos, personalidades e valores culturais específicos, singulares); avaliações positivas (apreciação das qualidades, simpatia, preferência) e engajamento dos públicos da marca. Por meio desses materiais, as marcas emitem seus discursos que são o foco de investigação do presente trabalho, especificamente os discursos visuais cromáticos.

... as marcas têm o dom da fala. As marcas só podem existir se comunicarem. Na verdade, ficam obsoletas se permanecerem silenciosas ou não utilizadas durante muito tempo. Uma vez que uma marca é um discurso em si (na medida em que fala dos produtos que cria e endossa os produtos que a encarnam), pode ser analisada como qualquer outro discurso ou forma de comunicação. (Kapferer, 2012, p. 187)

\subsubsection{A perspectiva do consumidor}

A perspectiva do consumidor investiga os papéis das marcas e do branding na vida cotidiana dos consumidores e na cultura do consumo contemporâneo, discutindo as múltiplas

\footnotetext{
${ }^{7}$ Sigla de Uniform Resource Locator, a forma padronizada de representação de diferentes documentos, mídias e serviços de rede na internet, capaz de fornecer a cada documento um endereço único. Fonte: Dicionário Português Oxford University Press @ 2012 Editora Objetiva. Versão eletrônica para Macintosh.
} 
maneiras pelas quais os indivíduos interpretam as mensagens marcárias, criando e vivendo identidades e novos conceitos de si, em colaboração com marcas (Schroeder, 2017, p. 5). Na tese, esse olhar examina as cores aplicadas às marcas para além do aspecto estético-funcional da cor que tinge ou ilumina produtos e serviços: como signo-cor de individualidades, personalidades, estilos e valores de vida, para o próprio indivíduo que compra e usa marcas, e para os outros.

\begin{abstract}
Se é dito que a função essencial da linguagem é a sua capacidade de poesia, devemos assumir que a função essencial do consumo é a sua capacidade de fazer sentido. Esqueça a ideia de irracionalidade do consumidor... tente, em vez disso, a ideia de que as mercadorias são boas para pensar; trate-as como um meio não-verbal para a faculdade criativa humana. ${ }^{8}$ (Douglas \& Isherwood, 1979/1996, pp. 40-41)
\end{abstract}

Assumindo que as cores formam e fortalecem vínculos de sentido entre as pessoas e entre as marcas e as pessoas, quando compartilham suas cores, a tese participa da conceituação do "consumidor visual": "uma maneira de ser um consumidor e de "fazer' consumo", exercitando ou experimentando as facetas, capacidades e habilidades visuais, "pelas quais os indivíduos ‘fazem sentido' de si mesmos e de seus ambientes sociais e de mercado" (Peñaloza \& Thompson, 2014, pp. 81-82).

\title{
1.1.2.3 A perspectiva cultural
}

A perspectiva cultural considera a marca primeiramente como parte da cultura, investigando o papel dos mitos e histórias das marcas em influenciar e refletir as ideologias, os estilos de vida e os valores culturais dos indivíduos, em um contexto espaço-temporal específico (Schroeder, 2017, p. 7). As marcas são repositório de conceitos e valores culturais de uma sociedade, transferidos do mundo culturalmente constituído por meio da "propaganda e outros mecanismos do marketing” (McCracken, 1993, p. 126), e das marcas para os indivíduos, por meio dos rituais de consumo (McCracken, 1986).

A tese encara a cor como um vetor potencial de transferência de significado: as cores carregam associações diversas, que podem ou não ser transferidas para a marca que as aplica

\footnotetext{
8 "If it is said that the essential function of language is its capacity for poetry, we shall assume that the essential function of consumption is its capacity to make sense. Forget the idea of consumer irrationality. [...] try instead the idea that commodities are good for thinking; treat them as a nonverbal medium for the human creative faculty".
} 
em seus pontos-de-contato. Do mesmo modo, essas associações (valores, ideias, etc.) podem ser transferidas para os consumidores, ao se engajarem em atividades de posse, uso, arrumação ou descarte da marca. Esse processo, longe de ser determinístico ou assegurado, é uma negociação simbólica entre consumidores e marcas:

\begin{abstract}
A cultura do consumidor é a infraestrutura ideológica que sustenta o que e como as pessoas consomem, e estabelece as regras básicas das atividades do branding. O paradigma da marca é o conjunto de princípios que estruturam como as empresas buscam construir suas marcas. Esses princípios funcionam dentro dos pressupostos axiomáticos da cultura de consumo existente. À medida que as empresas competem e experimentam dentro do universo de possibilidades definidas por esses princípios, elas emanam uma variedade de técnicas de branding. Como parte de um tênue consenso mantido pelas ações coletivas de consumidores e comerciantes, a cultura do consumo enganosamente conota um equilíbrio para o que é, na verdade, um relacionamento dialético e dinâmico. Contradições entre a cultura do consumo e o paradigma de branding levam a mudanças, de ambos. ${ }^{9}$ (Holt, 2002, p. 80)
\end{abstract}

Ao analisar como as marcas usam as cores estrategicamente e como os indivíduosconsumidores agem e reagem frente a esse uso, a tese colabora para um entendimento do processo dialético de cocriação de sentidos entre indivíduos e marcas, mediado pelas cores.

\title{
1.1.2.4 A perspectiva crítica
}

A perspectiva crítica do branding investiga as funções éticas, ideológicas e políticas da marca, sua influência na vida dos consumidores e funcionários, e a invasão da lógica marcária sobre a esfera pública e a individual. (Schroeder, 2017, p. 8). Os ativistas "antibranding" argumentam que a expansão por domínios de marca coincidiu com o abandono da esfera pública pelos governos, disponibilizando ideias, instituições e espaços até então comunitários - como nações e cidades, hospitais, escolas, bibliotecas e festivais - a se tornarem "uma colcha de retalhos de significados de marca" (N. Klein, 2004, p. 177).

\footnotetext{
9 "Consumer culture is the ideological infrastructure that undergirds what and how people consume and sets the ground rules for marketers' branding activities. The branding paradigm is the set of principles that structures how firms seek to build their brands. These principles work within the axiomatic assumptions of the extant consumer culture. As firms compete and experiment within the universe of possibilities defined by these principles, they derive a variety of branding techniques. As part of a tenuous consensus maintained by the collective actions of consumers and marketers, consumer culture deceptively connotes an equilibrium for what is actually a dynamic dialectical relationship. Contradictions between consumer culture and the branding paradigm propel institutional shifts in both".
} 
Em um extremo da visão crítica, além de interferirem nas estruturas econômicas e socioculturais, a exacerbação do consumo de marcas e o processo de globalização influenciam, direta ou indiretamente, as relações interpessoais e a subjetividade humana, fazendo esquecer "a oposição fundamental entre a figura do consumidor e a figura do cidadão", minando a solidariedade da vida social (M. Santos, 2008, p. 45). Porém, refutando a ideia de uma relação unilateral entre produtores-emissores coercitivos e consumidores-receptores passivos, o consumo é visto também como um lugar de disputa, onde os indivíduos distinguem-se uns dos outros, demandam o que valorizam e interagem ativamente: "o consumo serve para pensar" e pode ser repensado em uma necessária reconquista criativa do que é público (Canclini, 1999).

$\mathrm{Na}$ tese, a perspectiva crítica é trazida com a investigação dos discursos de empresas e governos sobre pertinentes embates sociais da atualidade, nos quais a cor foi usada estrategicamente. Por exemplo, as questões do gênero e dos diretos LGBT (o arco-íris ou o rosa-choque como marcadores de ativistas e simpatizantes), o combate ao racismo (repensando o uso das cores e dos termos "branco" e "preto"), a defesa do meio-ambiente (o verde marcando instituições e ofertas amigas da natureza ou da saúde humana), e campanhas de saúde pública (outubro-rosa para prevenir e combater o câncer de mama, novembro-azul para o de próstata, dezembro-laranja para o câncer de pele, etc.).

Conforme será discutido neste trabalho, nem todas as marcas verdes são saudáveis e nem todas as marcas cor-de-rosa colaboram na prevenção do câncer mamário ou na igualdade entre homens, mulheres e indivíduos intersexuais. Se por um lado muitos consumidores compram o discurso "colorido", por outro ele provoca reações negativas de cidadãos-comuns, de celebridades e de instâncias coletivas, públicas ou privadas. O olhar crítico é parte imprescindível para entender dialética entre a cultura do consumidor e o paradigma de branding: a cor serve para pensar.

\subsubsection{A cor}

Dos primeiros registros da história da humanidade, os desenhos ocre-avermelhados do homem-das-cavernas, até as atuais telas multicoloridas dos tablets e celulares repletos de apps ${ }^{10}$ (marcas!), muito se criou e se descobriu com e sobre a cor. Apesar das cores não serem há

\footnotetext{
10 Softwares também conhecidos como "aplicativos móveis", desenhados para realizarem tarefas específicas em um dispositivo eletrônico móvel.
} 
tempos apenas uma questão de sobrevivência, o desenvolvimento do sentido da visão e a evolução da espécie humana são processos indissociáveis: as pessoas, quando dotadas de visão considerada normal, obtém a maior parte da informação do mundo (e da memória desse mundo) pelo que percebem visualmente, as cores incluídas.

A cor, mais do que um fato objetivo, externo ao ser humano, é uma experiência, uma percepção subjetiva, individual. Embora o foco desta tese seja a relação simbólica entre cores e marcas, é preciso falar, ainda que simplificada e resumidamente, sobre os aspectos ótico, anatômico e psicofisiológico, para se tenha uma visão geral e atualizada do fenômeno cor.

\subsubsection{Antes da cor, a luz (a dimensão ótica)}

A luz é um tipo específico de radiação eletromagnética (Figura 1.5) que, a depender do conteúdo de energia, varia de nome (Kuehni, 2012, p. 3): raios gama, raios X (que atravessam o corpo humano e podem causar danos em exposições prolongadas), ultravioleta (que pode queimar ou bronzear), luz (que proporciona informação visual), infravermelho (que esquenta o corpo), micro-ondas, ondas de rádio (transmissão de informação) ou eletricidade (utilizada como fonte de energia).

Figura 1.5: O espectro eletromagnético, em ordem crescente de comprimento de onda.

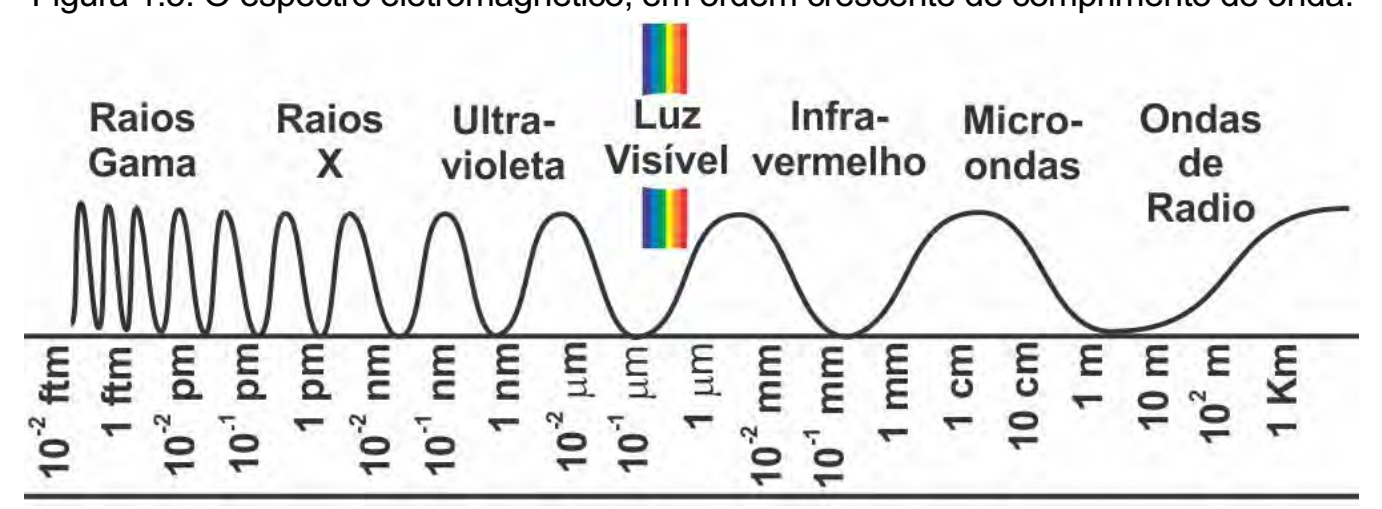

Fonte: Portal Pontociência (Paula, 2012).

O comprimento de onda da luz visível ao ser humano está situado entre 400 e 700 nanômetros ${ }^{11}$ : as ondas de 400 a 450nm aproximadamente, são percebidas como violeta; de 450 a 500nm como azul; de 500 a 540nm como verde; de 540 a 590nm, amarelo; de 590 a 650nm como laranja; e de 650 a 700nm são percebidas como vermelho (Zollinger, 1999, p. 64).

\footnotetext{
${ }^{11} \mathrm{Nm}$, bilionésimo de metro, ou $10^{-9} \mathrm{~m}$.
} 
A relação das cores com a luz foi estipulada cientificamente por Isaac Newton, com os experimentos sobre a divisão da luz solar pela refração. Com a ajuda de um prisma, Newton separou a luz branca em faixas espectrais, descoberta que é considerada a fundação da óptica moderna. Os resultados foram publicados em 1672, na "Philosophical Transactions of The Royal Society", e décadas mais tarde no livro Optika (Newton, 1704/1718), reproduzindo versões detalhadas dos experimentos, fortalecendo o empirismo e rebatendo as críticas que contestavam seus resultados anteriores (Fara, 2015).

Em Optika, o cientista organizou ineditamente as cores espectrais no perímetro de um círculo (Figura 1.6), conjugando o conceito físico da cor e seu significado perceptivo, ao aproximar o violeta e o vermelho. Deste modo, as duas cores não foram colocadas em oposição, como extremos de uma organização em linha reta, mas em proximidade perceptual (Mozeglio, 1972, pp. 89-90).

Figura 1.6: O círculo cromático de Newton, de 1704.

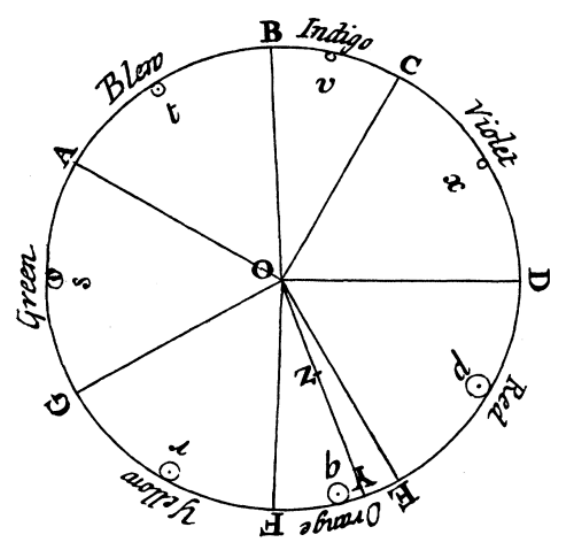

Fonte: Optika, de Newton (1704/1718, Book I, Part II, Plate III).

Efetuando a transição de um sistema linear para um bidimensional, Newton criou o primeiro reconhecido círculo cromático, sem a aplicação de cor, mas indicando uma "diluição" até o branco no ponto central. O esquema foi ponto de partida para inúmeros estudos sobre organização e harmonia cromáticas nos séculos seguintes, como por exemplo, o conceito de "cores complementares" (vermelho-verde, amarelo-violeta, azul-laranja), definido por pesquisadores alemães e franceses no início do século XIX, referente às cores dispostas em oposição, no círculo (Gage, 2012, pp. 33-35).

Ao longo de três séculos, ultrapassadas as limitações da época (e das teorias) de Newton, a luz é concebida como energia eletromagnética, de natureza dual: ora se comporta como onda, ora se comporta como energia (quantum ou fóton). Mas a dualidade onda-partícula 
não foi a única controvérsia nos estudos da cor na era moderna: a questão das cores primárias, irreduzíveis, e que dão origem a todas as outras por meio das misturas, rivalizou artistas, filósofos e cientistas por muito tempo (Riley, 1995, p. 3).

Para Newton, por exemplo, existiam sete cores primárias (Newton, 1704/1718, p. 134) - vermelho, laranja, amarelo, verde, azul, índigo e violeta - em uma referência aos sete tons da escala musical diatônica, musica mundana, a harmonia universal que regeria o mundo. Para Goethe (1810), em sua obra "Doutrina das cores" eram três as cores básicas, puras e prontas, para os pintores - amarelo, azul e vermelho (Goethe, 1810/1993, p. 106), - embora somente as duas primeiras fossem as cores básicas, para um físico (p. 124).

Apesar de equivocado do ponto-de-vista da física ótica, Goethe foi pioneiro ao levantar aspectos fisiológicos e psíquicos das cores e, de um certo modo, pressentiu os dois tipos de síntese cromática, a aditiva e a subtrativa (Figura 1.7), distinguidos cientificamente apenas em 1852, pelo cientista alemão Hermann von Helmholtz (Kuehni, 2003, p. 72).

Figura 1.7: (a) Sistema aditivo (RGB) em simulação das luzes-cores primárias sobre fundo preto; (b) Sistema subtrativo (CMY), com as três cores primarias sobre fundo branco.

(a)

(b)

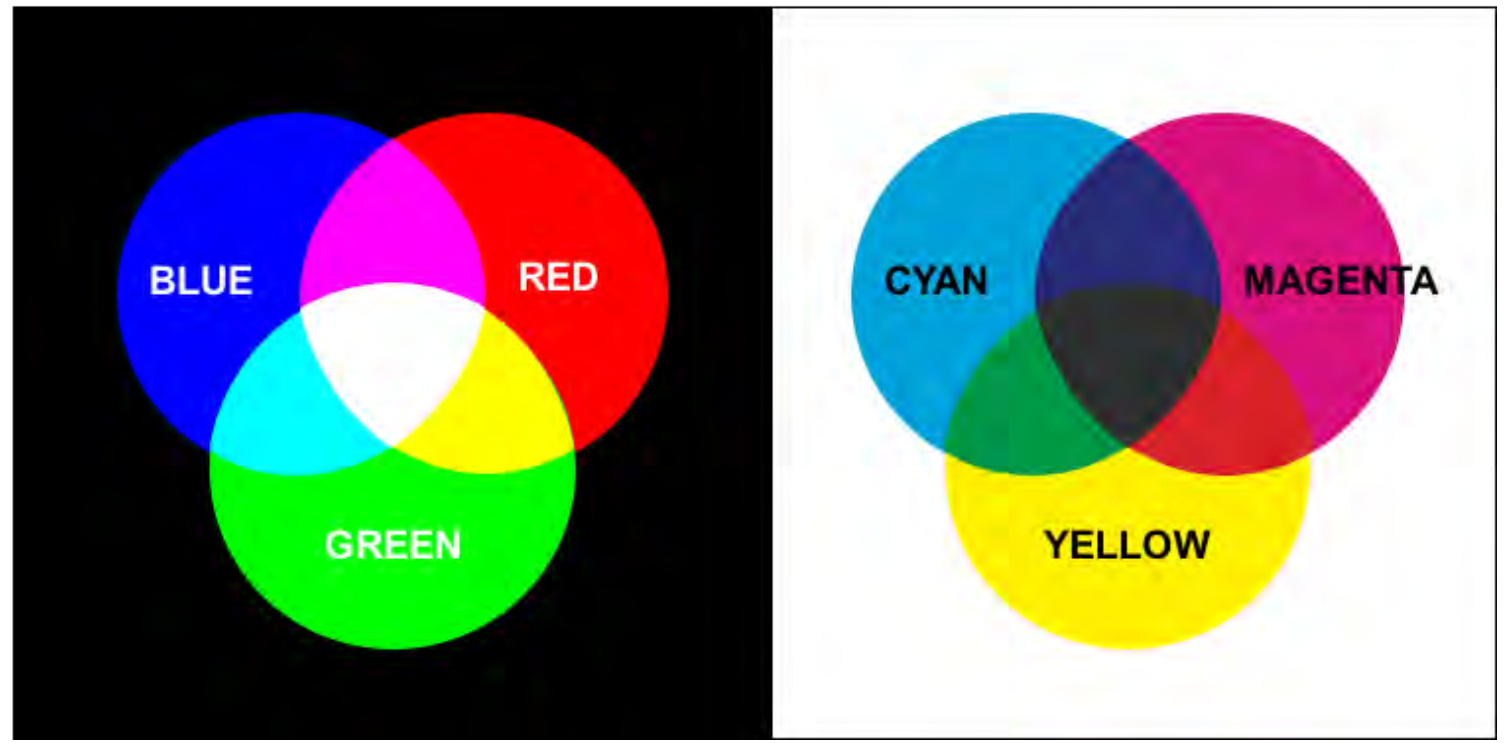

Fonte: Desenvolvido pela autora.

Na mistura aditiva, as cores são obtidas pela soma de luzes coloridas e a cada cor-luz adicionada, mais clara (próxima do branco) é a mistura final. As três primárias aditivas são o vermelho-alaranjado (red), verde (green) violeta-azulado (blue), que definem, por exemplo, o sistema RGB desenvolvido para o lançamento da TV a cores. Diferentemente, no sistema subtrativo as cores-pigmento primárias são o vermelho, azul e amarelo, que chegam (próximas) 
ao preto, na medida em que são misturadas. Adaptadas para o sistema de impressão a cores, o magenta, o ciano (cyan) e o amarelo (yellow) formam o sistema CMY, que somado ao preto (black), configura o sistema CMYK.

\subsubsection{O aparato visual humano (a dimensão anatômica)}

O ato de "ver" inicia-se no olho, o receptor da visão, órgão responsável por captar as informações luminosas e transformá-las em impulsos elétricos. O olho humano (Figura 1.8) é um globo esférico rotatório, no qual a luz entra ao atravessar a córnea, lente externa de grande poder de convergência (Lent, 2004, p. 209).

Figura 1.8: As principais estruturas do olho humano (representado em corte).

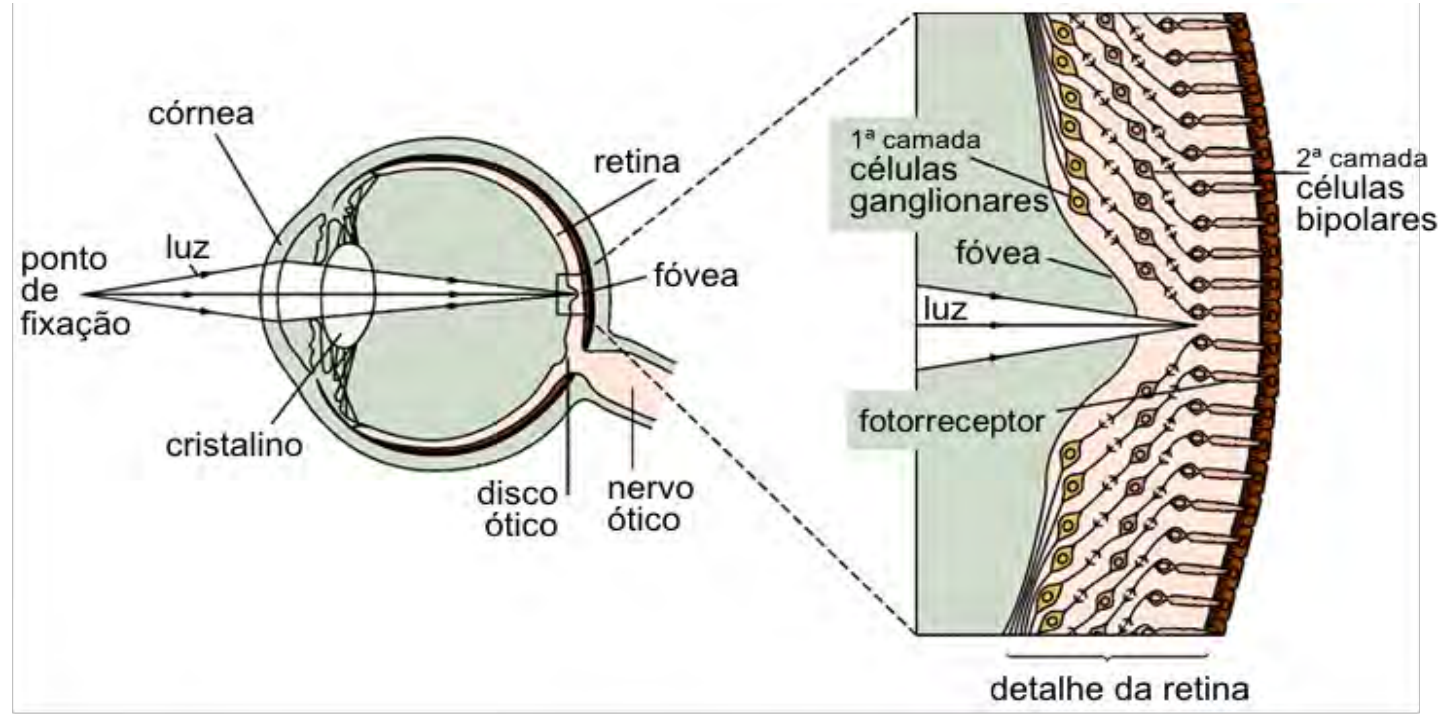

Fonte: Traduzido de Tessier-Lavigne (2000, p. 508).

Atrás da córnea está a íris, diafragma cuja estrutura circular de pigmentação variável confere a "cor dos olhos". Ao se contrair e se expandir, aumenta ou diminui o diâmetro da pupila, orifício que dá passagem à luz. A variação no diâmetro contribui para a focalização da imagem e controla a intensidade de luz que incidirá na retina, junto com o movimento das pálpebras. O cristalino é a segunda lente do olho, uma estrutura transparente biconvexa, atrás da íris. Não é tão convergente quanto a córnea, mas sua flexibilidade (comandada pelos músculos ciliares) é a maior responsável pela focalização de objetos a diferentes distâncias, na retina uma capacidade de acomodação que se reduz com a idade, doenças ou lesões (Bicas, 1997). Atrás do cristalino está a câmara vítrea, preenchida pelo humor vítreo (um gel transparente) que toca a retina, estrutura do olho que é parte do sistema nervoso central. 
A retina recobre a parte interna da câmera vítrea, e na sua parte sensorial (ao fundo do olho), é onde os raios luminosos são projetados e transformados em sinais elétricos (transdução) pelas células fotorreceptoras (cones e bastonetes). Ela tem apenas 1/4 de milímetro de espessura e é formada por três camadas de células nervosas (Hubel, 1995, p. 3). No centro da retina está a fóvea, pequena área de maior acuidade visual, onde os fotorreceptores são apenas cones (sem bastonetes): o olho humano está em constante movimento para projetar a imagem da cena de interesse exatamente sobre a ela.

Uma vez que os fotorreceptores estão nas camadas mais profundas da retina, na área da fóvea os vasos sanguíneos e outros neurônios retinais (duas camadas superiores) estão afastados para os lados. Isso ocorre para que os raios luminosos não sejam absorvidos ou dispersados antes de chegarem aos fotorreceptores, o que causaria distorção das imagens.

Realizada a transdução, os impulsos elétricos "sobem" as camadas da retina até encontrarem as fibras óticas, que se agrupam no disco ótico, de onde saem como nervos óticos (esquerdo e direito). Eles se cruzam parcialmente (no quiasma ótico), e seguem em direção córtex cerebral, onde mais processamento da informação bioelétrica será necessário para que se complete o processo de percepção visual: o "ver” (Tessier-Lavigne, 2000, p. 508).

\subsubsection{A cor está na sua mente (a dimensão psicofísiológica)}

Se a anatomia do aparato visual humano já é bem conhecia, o mesmo não se pode falar do processo da visão. Apesar dos avanços da neurofisiologia, não são totalmente abrangentes ou válidas as teorias que explicam como os sinais elétricos biologicamente produzidos (energia luminosa absorvida e transduzida pelos fotorreceptores) resultam na experiência da visão. Sabe-se que a informação sobre movimento, profundidade, forma e cor é processada em diferentes áreas e organizada por (ao menos) dois caminhos corticais distintos, não excludentes. Mas como esse distribuído processamento gera uma percepção visual única, coesa, ainda é um mistério a ser entendido (Wurtz \& Kandel, 2000, p. 566).

Sobre a visão das cores, sabe-se que existem dois tipos de fotorreceptores, os cones e os bastonetes, ambos realizadores da fototransdução - a tradução ou codificação dos parâmetros de estímulo eletromagnético (luz) para a linguagem bioelétrica. Apesar de morfologicamente semelhantes, os cones e os bastonetes possuem funcionalidades diferentes. Os bastonetes, muito mais numerosos, são extremamente sensíveis à luz e responsáveis pela visão em condição de 
baixa luminosidade (visão noturna): distinguem tons de cinza, mas não diferenciam as cores (Hubel, 1995, p. 3).

Os cones, responsáveis pela visão das cores e da visão de detalhes, são especializados para a visão diurna. São subdivididos em três tipos, definidos conforme o foto-pigmento que contém e da consequente faixa de comprimento de onda que absorvem (Lennie, 2000): os cones tipo S (small, ou "cones azuis") têm pico de absorção para comprimentos de onda curtos; os cones M (medium, "cones verdes") têm pico de absorção para as ondas do meio do espectro; e os do tipo L (large, os “cones vermelhos") têm pico com os comprimentos de onda mais longos. Assim, a mente obtém informação sobre as cores comparando as respostas dos três tipos de cones (Tessier-Lavigne, 2000, p. 509), definindo a visão humana como tricromática ${ }^{12}$.

Nem tudo o que os olhos detectam o cérebro enxerga: a atenção, o sono, as emoções, o ambiente, condicionamentos e outros mecanismos de filtro do sistema nervoso, bloqueiam informações "irrelevantes", ou as que a mente considera como tal. Dos cerca de 10 milhões de bits de informação processados por segundo, apenas 40 bits são levados à consciência ("percebidos"), enquanto as demais informações são utilizadas para processamentos não conscientes, que influenciam atividades internas do corpo ou movimentos não pensados, como os reflexos (Kuehni, 2012, p. 26)

Além disso, uma mesma informação luminosa pode ser "percebida" pelo cérebro diferentemente: a aparência cromática de um objeto não depende apenas do comprimento de onda que ele emite/reflete, mas também de variáveis do contexto. Por exemplo, o tipo de iluminação ambiente (solar, de uma lâmpada incandescente ou fluorescente), as cores do entorno (Lennie, 2000, p. 572), a textura e o tamanho da amostra colorida.

Os efeitos de contraste simultâneo e contraste sucessivo são exemplos dessa "ilusão de ótica" cromática. No contraste simultâneo, causa e efeito acontecem ao mesmo tempo: duas amostras de cor, apesar de idênticas, são percebidas como diferentes em função da cor do fundo em que estão aplicadas (Kuehni, 2003, p. 137). No contraste sucessivo, a afterimage (acromática ou cromática) é percebida durante alguns segundos, visualizada com os olhos fechados ou abertos, após uma exposição prolongada (olhar fixamente por 20 segundos ou mais) a um

\footnotetext{
12 A teoria tricromática, conhecida como Young-Helmholtz, é o resultado de estudos do séc. XIX, Thomas Young (1773-1829) James Maxwell (1831-1879) e Hermann von Helmholtz (1821-1894) (Zollinger, 1999, p. 7).
} 
relativamente forte estímulo visual (Kuehni, 2012, p. 75). Esses efeitos foram explorados por artistas e estudiosos da cor antes mesmo de serem experimentalmente demonstrados.

Michel Eugène Chevreul, por exemplo, foi contratado pela Manufatura Imperial de Gobelins nos anos 1820, para regularizar os corantes de tapeçaria: a companhia parisiense queria obter um fio de lã preto que fosse percebido como tal, e não como o preto "desbotado" que aparecia nas peças. O químico francês indicou que o problema não era o corante, mas os efeitos subjetivos provocados por algumas cores quando adjacentes aos fios de lã pretos. As descobertas de Chevreul foram descritas no livro de 1839, De la loi du contraste simultané des couleurs ("Da lei do contraste simultâneo das cores"), publicado quando ele já ministrava palestras para pintores interessados em aumentar o contraste em suas telas, por meio da justaposição de cores complementares (Gage, 1999, p. 196).

\subsubsection{O entendimento moderno de cor}

Atualmente, a cor é concebida em três dimensões (Figura 1.9), os três parâmetros fisiológicos básicos da visão de cores: matiz, luminosidade (ou brilho) e saturação (ou croma). Esses três atributos foram testados experimentalmente por Helmholtz em 1867, no livro "Manual de óptica fisiológica" (Handbuch der physiologischen Optik), mas já haviam sido sugeridos por Newton dois séculos antes (Kuehni, 2012, p. 204). Sob a estrutura teóricametodológica da tese, esses atributos são considerados como elementos sintáticos da cor.

\section{Matiz}

O matiz é entendido como o mais proeminente aspecto da cor, pois é por ele que se denominam as cores. Os quatro matizes elementares, em muitas línguas e culturas, são o amarelo, vermelho, azul e verde. A distância perceptual entre o amarelo e o vermelho forma a percepção do que é o laranja; entre vermelho e azul, o que é roxo; entre o amarelo e o verde, o amareloesverdeado; entre o azul e o verde, um azul-esverdeado (Kuehni \& Schwarz, 2008, p. 93).

\section{Luminosidade ou brilho}

Luminosidade (para superfícies refletoras) ou brilho (para superfícies emissoras de luz, como telas de computador ou TV) é tecnicamente definida pela luz percebida (refletida ou emitida) de um objeto não-branco comparado com um objeto perfeitamente branco, nas mesmas condições de iluminação (Kuehni, 2012, p. 56). Tecnicamente, a luminosidade ou brilho podem ser mensurados por um fotômetro, que indica a intensidade do feixe de fótons ao passar pelo filtro espectral, que simula a percepção de brilho da visão humana. O termo "valor" também é 
utilizado para indicar essa dimensão da cor: quanto mais clara a cor, mais "alto" o valor; quanto mais escura, mais baixo o valor.

\section{Saturação ou croma}

Esse Atributo refere-se à intensidade de uma cor. A saturação tem o branco como ponto de referência: quando a saturação é alta, a cor geralmente é chamada de "cor-viva" (Pedrosa, 2008, p. 35), enquanto as cores-pastel têm baixa saturação (mais próximas do branco). O croma, conceito desenvolvido por Albert Munsell no início do século XX, é coloquialmente usado como sinônimo de saturação, mas possui uma diferença importante: refere-se ao nível da distância de uma cor em relação ao seu cinza correspondente (e não ao branco). Quanto mais acinzentada (ou "neutra") a cor, menor é o croma; quanto mais intensa ou "pura", maior o croma (Shevell, 2003, p. 163).

Figura 1.9: As três dimensões da cor: (a) matiz, organizado em um círculo cromático, luminosidade (eixo vertical) e chroma (eixo horizontal) - do matiz (b) vermelho e (c) azul.

(a)

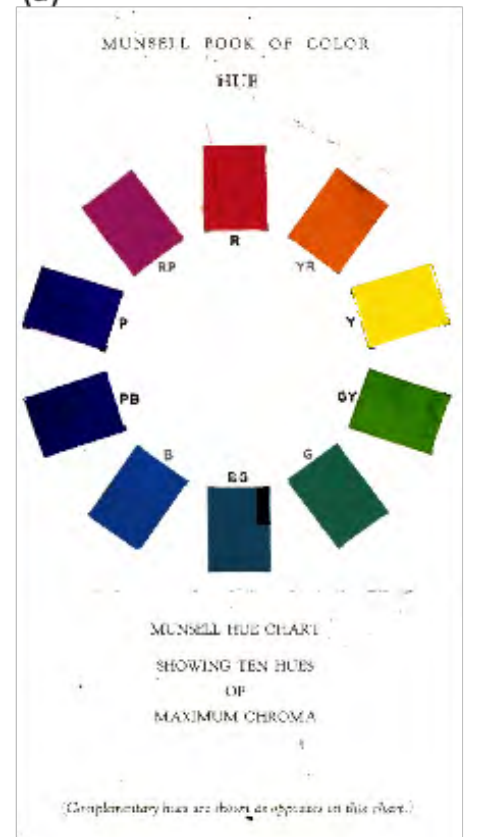

(b)

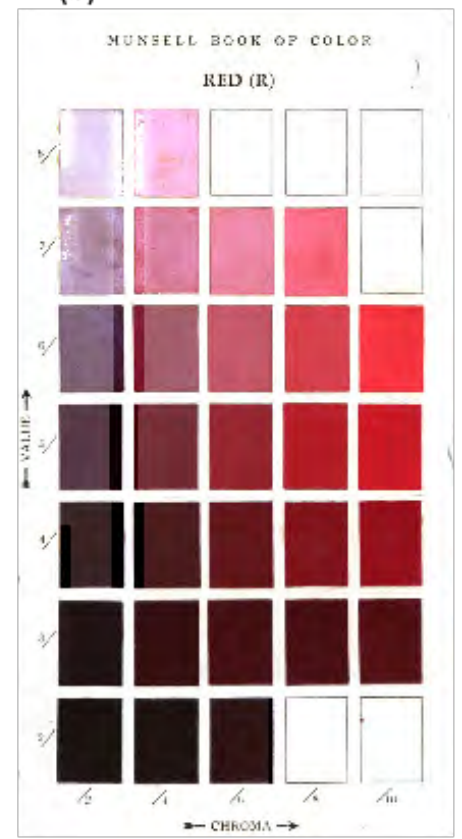

(c)

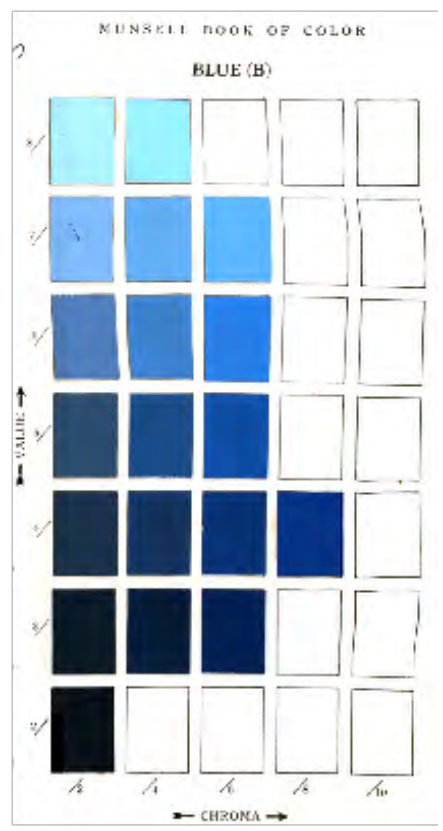

Fonte: Munsell Book of Color (Munsell, 1907/1929, pp. 8, 17, 43).

Hoje em dia, o ser humano descrimina as cores primeiramente pelo matiz, mas nem sempre foi assim: na idade média, as cores eram reconhecidas em função da luminosidade, ou seja, por sua posição entre o branco e o preto (Gage, 1999, p. 56). O que parece muito intuitivo e natural atualmente, na verdade é resultado de uma longa história de pesquisas e experimentações com as cores. 
Conforme discutido, foi a partir da descoberta de Newton que a cor passou a ser investigada como "sistema" ordenável por processamento de dados numericamente estipulados (Mozeglio, 1972, p. 88). Porém, exercícios de ordenação cromática, sob algum critério ou lógica, são numerosos e muito anteriores a Newton: Aristóteles e Leonardo da Vinci são algumas das personalidades históricas que propuseram modelos de cores, interesse de estudo há mais de dois milênios.

Do mesmo modo, são inúmeras as regras sobre combinações cromáticas. Os cientistas, artistas, designers e educadores, ao longo dos séculos da história ocidental, propuseram leis de harmonia das cores, associadas a aspectos físicos, fisiológicos e simbólicos. Porém, o que Aristóteles, da Vinci, Newton, Goethe, Chevreul, Munsell, entre muitos outros, estipularam como belo ou harmônico, foi mais ou menos relevante apenas por um período de tempo, em um local ou grupo específico. A moda, o design e as marcas são claros exemplos da efemeridade das regras e preferências de cor, definidas por doutrinas e cultura vigentes - não existem leis naturais ou princípios universais sobre uma harmonia estética-cromática (Kuehni \& Schwarz, 2008, p. 98).

Segundo a neurociência, o mundo real é diferente do mundo percebido e duas pessoas não percebem o mundo de forma igual. As distintas percepções ocorrem pelas limitações e habilidades da capacidade sensorial individual (razões genéticas e ambientais), ou devido aos estados fisiológicos e psicológicos pelos quais passa o indivíduo durante o seu dia e ao longo de sua vida, que alteram as informações sensoriais (Lent, 2004, p. 185).

Sob essa perspectiva, uma cor, ou combinação de cores, nunca é a mesma para dois consumidores diferentes. Seja ela aplicada em uma embalagem de marca (na estante do supermercado, no armário de casa), seja ela no mundo natural (em um arco-íris, junto com o cinza das nuvens de chuva e a luz quente do sol).

Com tantos mistérios e subjetividades ligados à percepção cromática, investigar a cor torna-se mais desafiador e relevante. Além de manifestar visualmente a marca e diferenciá-la dos concorrentes, a cor é signo de marca, colorindo ou desbotando valores, relações e estruturas, quando usada e consumida por pessoas, times, comunidades, políticos e partidos, países, ONGs, empresas. Após mais de 30 mil anos de práticas e estudos, as cores ainda são um enigma para os seres humanos, que esta tese ousa enfrentar em uma de suas múltiplas facetas: a dimensão semântica-pragmática da cor, no contexto do consumo. 


\subsection{Problema, hipótese e justificativa}

No contexto pós-moderno, onde o que se consome passou a ser "as ideias, as imagens, as emoções, os imaginários, as histórias" (Semprini, 2000, p. 47), qual a importância do elemento cor na expressão e comunicação visual de marca e na produção de vínculos de sentido entre a marca e seus públicos de interesse? Quais os efeitos da cor nos consumidores? Como e com quais objetivos a marca explora as cores?

\subsubsection{Hipótese geral}

Para responder a problematização acima, a tese apresenta a seguinte hipótese: a cor é um signo marcário que evoca variados efeitos de sentido nos indivíduos-consumidores e que exerce funções específicas no plano de comunicação de marca, ao ser aplicada nos pontos-de-contato por comunicadores, designers e gestores. Considerando seus efeitos e usos, o signo-cor é um elemento estratégico do discurso visual de marca.

\subsubsection{Justificativa}

As cores e demais elementos visuais são explorados há muito tempo e com sucesso na criação e comunicação de marca. Sob o ponto de vista da prática da mercado, as empresas realizam pesquisas de marketing para averiguar, entre outras coisas, os efeitos das cores aplicadas em logotipos, produtos, embalagens e propagandas, mas os resultados não são publicados por questões competitivas (Bellizzi, Crowley, \& Hasty, 1983, p. 26). As entrevistas realizadas no trabalho de campo desta tese confirmaram que a restrição, observada décadas atrás, é válida atualmente.

Sob o ponto de vista acadêmico, apesar de existirem muitos estudos sobre os aspectos físicos, fisiológicos e sobre a linguagem verbal das cores (nomenclatura cromática), ainda são poucos os trabalhos sobre a cor e o funcionamento psicológico humano (Elliot \& Maier, 2012). Escassos são também os trabalhos sobre cores aplicadas às marcas (Gorn, Chattopadhyay, Yi, \& Dahl, 1997). Além da ausência de uma teoria básica sobre a cor nos estudos mercadológicos e do consumo, a literatura existente é altamente fragmentada (Grossman \& Wisenblit, 1999).

Grande parte das pesquisas que olham para a interação entre cor, marca e consumo adotam uma abordagem pós-positivista, quantitativa, geralmente isolando/controlando o elemento cor para mensurar os efeitos sobre os indivíduos. Porém, essa abordagem do comportamento do consumidor (CB) não de dedica aos aspectos simbólicos ou interpretativos. 
Reconhecendo a importância crescente, na sociedade contemporânea, do comunicarse visualmente, seja por indivíduos como produtores-consumidores (com seus celulares e laptops, nos perfis do Facebook, Instagram, YouTube, etc.), ou como profissionais das mais diversas áreas (em seus power-points, infográficos, gifs e memes, vídeo-blogues, aulas e palestras à distância), esta tese responde à necessidade atual de se conduzir mais pesquisas sobre comunicação visual (Kenney, 2010, p. xv), em especial nos aspectos envolvidos no consumo de marca.

Assim, as justificativas deste trabalho se dão em quatro frentes, a seguir:

1. Originalidade: apesar da abrangente bibliografia sobre marca, sobre cor, e sobre consumo, não foi encontrado nenhum trabalho que explore em profundidade a interação cor-marca-consumo, configurando assim o carácter inédito deste estudo, no âmbito da comunicação visual estratégica;

2. Criatividade: a tese propõe uma releitura da tipologia semiótica Morrisiana pensada principalmente para signos verbais, tornando-a base para a elaboração de um modelo sistematizador do modo e do uso da cor na criação e comunicação marcárias, encarando a cor como um signo de marca;

3. Função social: ao colaborar para o letramento visual do cidadão-consumidor, o resultado final da tese pode instigá-lo a refletir mais criticamente sobre as ideologias e valores naturalizados por textos visuais, e capacitá-lo a tomar decisões mais conscientes sobre as imagens e marcas que consome, produz e faz circular ao longo da vida.

4. Relevância acadêmica e comercial: a tese instrumentaliza os comunicadores (publicitários, pesquisadores, professores, designers, gestores, etc.) sobre o potencial sígnico das cores aplicadas às marcas, para que assim as utilizem (e ensinem sobre a utilização) de modo mais ético e eficiente nos processos de criação e comunicação de marcas contemporâneas.

\subsection{Objetivos}

São três os objetivos específicos definidos, com os quais se alcança o objetivo geral.

\subsubsection{Objetivos específicos}

- Levantar e identificar pesquisas acadêmicas, bibliografia especializada e práticas do mercado sobre uso das cores pelas marcas, enfatizando três aspectos:

a) os efeitos da cor sobre os indivíduos-consumidores;

b) os objetivos ou funções do uso das cores;

c) como as marcas utilizam as cores, conforme os efeitos que querem causar.

- Abordar e discutir sob um olhar transdisciplinar (Comunicação, Marketing, 
Design), as aplicações de cor nos elementos de identidade e materiais de comunicação marcária, caracterizando-os conforme seus efeitos potenciais junto aos públicos e suas funções para as marcas;

- Analisar, classificar e relacionar os efeitos potenciais e as principais funções esperadas do uso das cores, em uma tipologia discursiva.

\subsubsection{Objetivo geral}

Criar uma tipologia semiótica dos discursos cromáticos da marca, inspirada na tipologia do discurso sígnico de Morris (1946), é o objetivo amplo e primeiro desta tese. O modelo gerado será um referencial teórico-metodológico para o estudos e prática da comunicação visual estratégica de marca, principalmente voltados para a comunicação e o design mercadológicos e a institucionais/ corporativos.

\subsection{Abordagem teórico-metodológica}

A transdisciplinaridade, condição fundamental para se obter uma concepção ampla do objeto de pesquisa, foi um importante desafio para a doutoranda, enfrentado por meio da articulação do conhecimento de diferentes áreas de estudo - principalmente Comunicação, Marketing e Design - que embora constituam campos específicos e autônomos, apresentam pontos de interceptação e complementação, conforme explica Souza (1997).

A fim de garantir uma unidade epistemológica à investigação, foi adotada uma estrutura-guia: a teoria semiótica de Morris, especialmente sua tipologia semiótica dos discursos cotidianos, resumidas a seguir.

\subsubsection{A semiótica de Charles W. Morris}

Filósofo, doutorado pela Universidade de Chicago, com a tese "Symbolism and reality: a study in the nature of mind" (1925/1993), Morris é considerado como um notável exemplar da escola semiótica Peirceana (Holbrook, 1987; Nöth, 1990; R. Posner, 1987). Para definir-se, Morris não gostava de nenhum tipo de rótulo, mas designou sua filosofia pluralista como "relativismo objetivo", uma teoria semiótica na qual os signos significam através da mediação do comportamento interpretativo (Fiordo, 1977, p. 14).

No livro Fundamentos da Teoria dos Signos (1938), escrito 13 anos após seu doutoramento, Morris apresentou seu trabalho baseado na semiótica de Charles S. Peirce, no 
behaviorismo social de George H. Mead e no logicismo de Rudolf Carnap (Morris, 1946, p. v). Estabelecendo conclusões sistemáticas de semelhanças entre o pragmatismo norte-americano, o empirismo anglo-americano e o positivismo lógico da Europa Central (R. Posner, 1987, p. 24), Morris separou a semiose (termo original de Peirce) em três dimensões - a sintática, a semântica e a pragmática - elementos que compõem até hoje a base fundamental desse campo de estudo (Nöth, 1990, p. 48).

Apesar de considerado um importante pensador americano por muitos desde o seu tempo (Osgood, 1966; Schepfler, 1975), Morris foi fortemente criticado devido a sua orientação behaviorista e positivista por acadêmicos das Artes (Gombrich, 1949), Biologia (Hill, 1957), Filosofia (Johnstone, 1973) e injustamente, segundo Mick (1986), acusado de ter compreendido mal a semiótica de Peirce.

\subsubsection{A teoria geral do signo e as dimensões da semiose}

Para Morris, seguindo a concepção triádica de Peirce, a semiose (semiosis) é um "processo em que algo funciona como signo para alguém", e possui três fatores que se implicam uns aos outros (Morris, 1938, p. 3):

- O veículo do signo (sign vehicle) que atua/funciona como signo;

- O designatum (aquilo a que o signo se refere), cuja eventual existência física chamou de denotatum;

- O interpretante (interpretant), o efeito sobre um intérprete para o qual a coisa em questão é um signo.

O intérprete, um organismo vivo, seria o quarto fator da semiose. O interpretante é o hábito desse organismo em responder a objetos ausentes (graças ao veículo sígnico, um mediador), mas relevantes em uma dada situação (Morris, 1938, p. 31).

A semiótica comportamental (ou behaviorista/behavioristic) de Morris (que é distinta do behaviorismo clássico da psicologia, de John B. Watson), define o comportamento como qualquer mudança em um organismo - um animal deixa de se comportar apenas quando morre (R. Posner, 1987). Um signo é um estímulo preparatório (mediador) que influencia ou desencadeia séries de respostas-sequências (de um certo comportamento-família), causando em algum organismo (o intérprete) uma disposição para responder (interpretante, ou um dar-se-conta) de uma certa maneira (Morris, 1938, p. 4). 
Para fins de estudo, é possível fazer abstrações para distinguir relações diádicas entre os três inseparáveis e interdependentes correlatos - o veículo sígnico, o designatum e o interpretante - estabelecendo as três dimensões da semiose: a sintática, a semântica e a pragmática. Deste modo, a semiótica estuda a semiose e é uma linguagem que fala sobre os signos, em suas três ramificações subordinadas (Morris, 1938, p. 8).

\section{A sintaxe: o estudo da dimensão sintática da semiose}

O termo sintaxe relaciona-se à dimensão sintática da semiose. A sintática é explicada por Morris como o estudo das relações formais de um signo com outros signos, das combinações sígnicas sujeitadas às regras sintáticas (Morris, 1938, p. 16). Na dimensão sintática, o signo pode ser classificado conforme o grau de precisão das expectativas que ele determina (Morris, 1938, p. 17):

- Indexal (indexical sign) - denota (como se apontasse) um único objeto. Restringe e especifica em grau máximo, enquanto define um mínimo de expectativas. Exemplos da linguagem verbal: "este", "essa";

- Caracterizante (characterizing sign) - denota uma pluralidade de coisas e é combinado com outros signos para explicar, especificar ou restringir seu alcance. Exemplos: "animal", "homem", "branco";

- Universal (universal sign) - denota qualquer coisa e se relaciona com qualquer outro signo, variando, conforme o grau de expectativa que é capaz de definir. É um signo amplo e pode criar muitas expectativas. Exemplos: "algo", "objeto", "entidade".

Em uma dada proposição sígnica, existe um signo caracterizante dominante e outros caracterizantes especificadores, relativos uns aos outros. São as condições de uso dos signos (a dimensão pragmática) que evidenciam qual é o signo dominante (Morris, 1938, pp. 18-19): na frase "aquele cavalo branco corre vagarosamente", o termo "branco" pode ser a referência mais específica, ou o termo "vagarosamente", a depender do contexto.

\section{A semântica: o estudo da dimensão semântica da semiose}

A semântica, enquanto ciência da semiótica, estuda as relações entre os signos e seus designata, os objetos que podem denotar ou (que realmente) denotam (Morris, 1938, p. 21), e posteriormente redefinida como o estudo da significação do signo. A dimensão semântica pressupõe a sintática e, em conjunto ou singularmente, são capazes de um relativo alto grau de autonomia (Morris, 1938, p. 29).

Nessa dimensão, e seguindo as ideias de Peirce, conforme as regras semânticas de denotação existem três tipos de signos (Morris, 1938, p. 24): 
- Índice (index) - designa o objeto para o qual direciona a atenção (com coordenadas espaço-temporais) sem caracterizá-lo, sem semelhança obrigatória com seu designatum;

- Ícone (icon) - signo que caracteriza o que pode denotar, pois mostra, nele mesmo, as propriedades ${ }^{13}$ ou um conjunto de características que seu designatum possui;

- Símbolo (symbol) - signo que designa objetos sem possuir características ou propriedades em comum, mas por regras que devem ser estabelecidas em temos de outros símbolos (cujas regras ou utilizações não estejam em questão).

\section{A pragmática: o estudo da dimensão pragmática da semiose}

A pragmática trata da relação dos signos com seus intérpretes, considerando os aspectos psicológicos, biológicos, e sociológicos envolvidos no funcionamento dos signos (Morris, 1938, p. 30). As regras pragmáticas estabelecem as condições (comportamentos, situações e hábitos) em que o veículo sígnico é um signo e desencadeia respostas dos intérpretes.

Tanto quanto a semântica pressupõe uma sintaxe bem desenvolvida, a dimensão pragmática pressupõe a sintaxe (o conhecimento das relações dos signos entre si) e a semântica (o conhecimento das relações entre signos e seus designata) para estudar a relação entre signos e seus intérpretes (Morris, 1938, p. 33).

Ao tornar a pragmática uma "disciplina moderna", Morris fez dela um campo de estudo explorado pela linguística no final da década de 1960, e que rapidamente se expandiu interdisciplinarmente. Hoje, a pragmática se dedica à "ação comunicativa em qualquer tipo de contexto", cujo paradigma de pesquisa é utilizado por investigações nas áreas das artes e humanidades, filosofia, ciências cognitivas, computacionais e ciências sociais, particularmente em economia, política e educação (Bublitz \& Norrick, 2011, p. 4).

\subsubsection{O eixo-estruturante da tese: a tipologia dos discursos sígnicos}

Em Signs, language and behavior (1946), Morris enfatizou sua inclinação comportamental ao propor a formulação de signo como um signo-comportamento (signbehavior), em função das "disposições de comportamento" que causa, influenciando os

\footnotetext{
13 "A questão da semelhança de propriedades definindo um signo icônico, definida por Peirce e seguida por Morris, é criticada por vários estudiosos, entre eles Umberto Eco, que define a iconicidade dos signos como a reprodução de equivalências perceptivas, possível por meio de códigos de reconhecimento, ou seja, não natural e sim um processo intencional" (S. Souza, 1999, p. 128).
} 
intérpretes (Morris, 1946, pp. 7-15). Na mesma obra, ele apresentou uma tipologia semiótica dos discursos, baseada em duas dimensões: um eixo semântico e um pragmático. O primeiro eixo trata da teoria de modos de significação, o segundo, da teoria sobre o uso dos signos, suas adequações, verdades e confiabilidades.

As teorias e a tipologia de Morris são utilizadas nesta tese como base teóricametodológica para a análise e classificação dos modos e dos usos das cores na marca e para propor uma tipologia semiótica dos discursos cromáticos de marca. A cor, aplicada nos logotipos, embalagens, mascotes, propaganda, ambientes e outros elementos da marca, é aqui considerada o signo, ou o "signo-cor". A marca é considerada o objeto (designatum), enquanto seus comunicadores, designers e gestores são o organismo produtor do signo (sign-producer) que usa a cor para alcançar seus objetivos: provocar determinadas disposições (interpretantes) nos públicos da marca (intérpretes).

A seguir, as duas dimensões da tipologia de Morris são detalhadas e nove questões de pesquisa são definidas. As cinco primeiras questões são referentes à dimensão semântica (modos de significação) e investigadas no capítulo 2, para a proposição de cinco modos da cor significar marcas. As quatro últimas questões, sobre a dimensão pragmática (usos sígnicos), são tratadas no capítulo 3, para a proposição de quatro principais usos da cor pelas marcas. No capítulo 4, no cruzamento dos modos e dos usos do signo-cor, surge a tipologia dos discursos cromáticos de marca, contribuição original maior e conclusiva da tese, inspirada na tipologia Morrisiana dos discursos cotidianos. Encerrando, as considerações finais brevemente reveem os questionamentos inspiradores das estratégicas discursivas cromáticas propostas, e sugerem futuros estudos sobre os demais elementos visuais de marca.

\section{A teoria dos modos de significação}

Pensando em termos comportamentais sobre os modos de significação do signo (características semânticas de qualquer signo), Morris definiu cinco categorias inter-relacionadas para mostrar as "diferentes maneiras em que algo pode ser significado" (Morris, 1946, p. 88):

- Modo identificativo - um signo (identificador) que significa algo (o objeto sígnico) por indicar a localização no espaço ou no tempo, ao intérprete;

- Modo designativo - um signo (designador) que significa algo por designar as propriedades ou características observáveis desse objeto, ao intérprete;

- Modo apreciativo - um signo (apreciador) que significa algo por provocar um status preferencial, uma apreciação negativa/positiva sobre esse objeto, ao intérprete; 
- Modo prescritivo - um signo (prescritor) que significa como o intérprete deve agir em relação a algo, ao objeto sígnico;

- Modo formativo - um signo (formador) que significa logicamente, gramaticalmente ou estruturalmente, por modificar uma significação prévia ao intérprete (dispositivos auxiliares para a combinação de signos).

Na abordagem comportamental Morrisiana, cada um dos modos de significação tem um interpretante correspondente, indicando os diferentes modos em que um signo dispõe um intérprete para responder (tendências a se comportar). Dizer que o signo está em um ou no outro modo, é dizer que ele opera para algum intérprete de uma ou outra maneira (Morris, 1946, p. 92):

- Interpretante identificativo: uma disposição em direção a uma localização espaço-temporal;

- Interpretante designativo: uma disposição para reagir ao objeto denotado como se ele tivesse certas propriedades observáveis;

- Interpretante apreciativo: uma disposição para julgar satisfatoriamente ou insatisfatoriamente o objeto denotado;

- Interpretante prescritivo: uma disposição para agir de determinada maneira em relação ao objeto (ou situação) denotado;

- Interpretante formativo: uma disposição para alterar as disposições anteriormente formadas por uma combinação de signos.

Por serem modos interdependentes e inter-relacionados, qualquer signo pode apresentar, em algum nível, aspectos de vários modos, embora seja comum definir a predominância de um deles, sempre considerando o contexto em que o signo se encontra. Por exemplo, na frase "Vamos comprar estas boas pimentas verdes?", os sinais "vamos" e “comprar" são prescritores, "nós" e "estas" são identificadores, "boas" é um signo no modo apreciativo, "verde" é designador-de-característica (character-designator). "Pimentas" é designador-de-objetos (object-designator) e “?” é um signo no modo formativo - significando a frase como uma dúvida, não uma afirmação.

Uma combinação de signos (uma inscrição, ou ascriptor) pode ser classificada de acordo com a proporção relativa de seus componentes (Morris, 1946, pp. 62-63) e conforme o contexto em que está situada (Morris, 1964, p. 5). O ascriptor exemplificado acima (a oração interrogativa sobre pimentas) pode ser classificado como predominantemente prescritivo, influenciando o intérprete a comprar (agir), ainda que a interrogação também localize, descreva e aprecie as pimentas. 
Baseadas na teoria de modos de significação de Morris, cinco questões de pesquisa foram definidas, buscando o entendimento dos modos em que cor opera como signo de marca:

A cor opera como signo de uma marca evocando em seus públicos... questão 1:

- uma disposição para localizar a marca em um tempo-espaço específico? (o signo-cor operando no modo identificativo);

questão 2:

- uma disposição para reagir como se a marca tivesse propriedades / características específicas?

(o signo-cor operando no modo designativo);

questão 3:

- uma disposição positiva/negativa em relação à marca? (o signo-cor operando no modo apreciativo);

questão 4:

- uma disposição para agir em relação à marca? (o signo-cor operando no modo prescritivo);

questão 5:

- uma disposição para alterar as disposições prévias em relação à marca? (o signo-cor operando no modo formativo).

Essas cinco perguntas originam a proposição de cinco modos da cor significar uma marca para seus públicos (capítulo 2). A classificação adapta e estende a original de Morris (1946) com embasamento na revisão de literatura acadêmica dos campos do Comportamento do Consumidor (CB), Consumer Culture Theory (CCT), Comunicação Visual e Design, de textos técnicos e jornalísticos sobre as práticas de mercado, bem como na análise dos dados obtidos pela pesquisa de campo - entrevistas em profundidade, visitas de observação participante, e coleta de artefatos.

\section{A teoria dos usos do signo}

As questões acima enfocam o interpretante - os diferentes comportamentos aos quais um signo pode dispor um intérprete. A presente seção, baseada na teoria de Morris sobre os usos sígnicos, contempla a fase de produção, "o propósito para qual um organismo produz o signo" (Morris, 1946, pp. 92-93), seja esse uso voluntário ou involuntário. Os quatro usos principais, inter-relacionados e interdependentes de qualquer signo são:

- Uso informativo: um signo cuja função principal é informar, corretamente ou incorretamente, sobre o que foi, é ou será;

- Uso avaliativo: um signo cuja função principal é conferir um status preferencial sobre algo, do menos (ou nada) ao mais preferível; 
- Uso incitivo: um signo cuja função principal é incitar uma ação particular em relação a objetos ou signos;

- Uso sistêmico: um signo cuja função principal é influenciar, reorganizar o comportamento além daquele previamente evocado pelos signos.

Morris denominou de "adequado" o uso sígnico que alcança o propósito almejado pelo produtor do signo (Morris, 1946, p. 97): o uso é convincente quando informa adequadamente sobre algo; é eficaz quando provoca uma avaliação, adequadamente; persuasivo quando incita uma ação, adequadamente; e correto quando sistematiza, adequadamente.

A fim de investigar o uso da cor pelas marcas, quatro questões foram definidas, correspondendo respectivamente a cada dimensão Morrisianas do uso de qualquer signo:

Como e por que (intenções estratégicas) a cor é usada...

questão 6:

- para informar convincentemente os públicos sobre as propriedades da marca? (uso informativo como a função principal da cor);

questão 7:

- para induzir eficazmente os públicos a estabelecerem uma preferência em relação à marca? (uso avaliativo como função principal da cor);

questão 8:

- para incitar persuasivamente seus públicos a agirem em função da marca? (uso incitivo como função principal da cor);

questão 9:

- para organizar corretamente os comportamentos dos públicos em relação à marca, previamente provocados por outros signos?

(uso sistêmico como função principal da cor).

Essas quatro perguntas, originam a proposição de quatro funções do uso da cor como signo de marca (capítulo 3). Assim como a classificação dos modos de significação, a categorização dos usos do signo-cor repensa a original de Morris (1946) com embasamento na revisão de literatura acadêmica, em textos técnicos e jornalísticos e na análise dos dados obtidos pela pesquisa de campo.

\section{Os 16 principais tipos de discursos do cotidiano}

Relacionando os modos de significação e os usos sígnicos, Morris estabeleceu 16 tipos de discursos da vida cotidiana, "especializações de linguagem" surgidas a fim de que 
certos objetivos pudessem ser adequadamente alcançados (Morris, 1946, p. 123). Os 16 tipos discursivos Morrisianos (Quadro 1.1) variam de acordo com o predomínio do modo de significação (eixo vertical) e o principal objetivo comunicativo do signo (eixo horizontal).

Quadro 1.1: Os principais tipos de discurso, segundo Morris.

\begin{tabular}{|c|c|c|c|c|}
\hline MODO USO & INFORMATIVO & AVALIATIVO & INCITIVO & SISTÊMICO \\
\hline DESIGNATIVO & $\begin{array}{c}\text { científico } \\
\text { (designativo-informativo) }\end{array}$ & $\begin{array}{c}\text { fictício } \\
\text { (designativo-avaliativo) }\end{array}$ & $\begin{array}{c}\text { legal } \\
\text { (designativo-incitivo) }\end{array}$ & $\begin{array}{c}\text { cosmológico } \\
\text { (designativo-sistêmico) }\end{array}$ \\
\hline APRECIATIVO & $\begin{array}{c}\text { mítico } \\
\text { (apreciativo-informativo) }\end{array}$ & $\begin{array}{c}\text { poético } \\
\text { (apreciativo-avaliativo) }\end{array}$ & $\begin{array}{c}\text { moral } \\
\text { (apreciativo-incitivo) }\end{array}$ & $\begin{array}{c}\text { crítico } \\
\text { (apreciativo-sistêmico) }\end{array}$ \\
\hline PRESCRITIVO & $\begin{array}{c}\text { tecnológico } \\
\text { (prescritivo-informativo) }\end{array}$ & $\begin{array}{c}\text { político } \\
\text { (prescritivo-avaliativo) }\end{array}$ & $\begin{array}{c}\text { religioso } \\
\text { (prescritivo-incitivo) }\end{array}$ & $\begin{array}{l}\text { propagandístico } \\
\text { (prescritivo-sistêmico) }\end{array}$ \\
\hline FORMATIVO & $\begin{array}{l}\text { lógico-matemático } \\
\text { (formativo-informativo) }\end{array}$ & $\begin{array}{c}\text { retórico } \\
\text { (formativo-avaliativo) }\end{array}$ & $\begin{array}{c}\text { gramatical } \\
\text { (formativo-incitivo) }\end{array}$ & $\begin{array}{c}\text { metafísico } \\
\text { (formativo-sistêmico) }\end{array}$ \\
\hline
\end{tabular}

Fonte: Traduzido de Morris (1946, p. 125).

Embora Morris tenha concebido suas teorias para qualquer tipo de signo, os nomes ilustrativos que ele criou para exemplificar os tipos discursivos ("mítico", "fictício", etc.) e o texto explicativo desses tipos (denominando o intérprete como "leitor"), evidenciam que o foco da análise Morrisiana foram os signos verbais. Entender, repensar e ampliar as teorias e a tipologia original para a comunicação visual estratégica de marca é o desafio intelectual-criativo enfrentado nesta tese (capítulo 4).

\subsection{Procedimentos metodológicos}

Os procedimentos empíricos-metodológicos foram pensados a fim embasar a confirmação/refutação e a adaptação/ampliação das teorias de modo e uso e da tipologia discursiva de Morris (1946). O enfoque qualitativo-interpretativo mostrou-se o adequado, uma vez que a investigação examina um fenômeno amplo e complexo para o qual as teorias existentes não são aplicáveis no contexto, ou são insuficientes para entendê-lo (Bonoma, 1985).

Dentro das técnicas qualitativas, o estudo de casos múltiplos (do tipo incorporado ${ }^{14}$ ), mostrou-se a mais indicada estratégia, considerando seu caráter original e a confluência de diferentes disciplinas. Por meio do estudo de caso é possível uma abordagem em triangulação

\footnotetext{
${ }^{14} \mathrm{O}$ tipo incorporado (embedded) refere-se ao estudo de caso com várias unidades de análises dentro de um mesmo caso, diferentemente do tipo holístico, com uma unidade para cada caso investigado (Yin, 2003, p. 46).
} 
metodológica, a combinação de múltiplas práticas qualitativas (hoje também quantitativa com qualitativa), cada qual com suas peculiaridades, que olha para o fenômeno de pesquisa a partir de mais de uma fonte de dados (Denzin, 2012).

As fontes de evidência mais comuns nos estudos de caso são: os documentos e arquivos, entrevistas, observação (direta ou participante) e artefatos físicos (Yin, 2003, p. 85). A triangulação de dados visuais com verbais, eletrônicos com tradicionais, etc., visa capturar aspectos mais profundos e diferentes (Flick, 2004, pp. 179-180). Nesta tese, as fontes de evidência escolhidas foram: entrevistas em profundidade com comunicadores, designers e gestores, visitas de observação em ambientes de marca e coleta de artefatos físicos e digitais.

A fim de suprir a dupla demanda de uma pesquisa entre o design exploratório e confirmatório (Miles \& Huberman, 1994, p. 20), a saída a campo foi realizada com o apoio de roteiros semiestruturados (ver Apêndices A, B e C), estipulados em função das duas teorias Morrisianas centrais da tese. Para as entrevistas, o foco foi capturar depoimentos sobre:

- Os efeitos das cores sobre os públicos de marca (relativos à teoria dos modos de significação);

- As práticas do uso das cores e os objetivos estratégicos que visavam atingir ao utilizarem as cores (relativos à teoria dos usos sígnicos).

Nas visitas de observação com coleta de artefatos, o foco de atenção voltou-se para:

- Como/o que a pesquisadora/visitante respondia (pensava, sentia, fazia) e como/o que os demais sujeitos no ambiente de marca reagiam (falavam, faziam), ao serem impactados pelas cores e demais estímulos multissensoriais (observações relativas à teoria dos modos de significação);

- Como a cor foi usada nas diferentes materializações visuais formadoras do ambiente de marca visitado (relativos à teoria dos usos sígnicos). Aqui, a experiência da pesquisadora, com mais de 20 anos atuando como consultora, designer e diretora de arte, mostrou-se um importante recurso instrumental.

$\mathrm{Na}$ medida em que os dados foram coletados e analisados sob a estrutura referencial teórica, as teorias de Morris eram refutadas, confirmadas ou repensadas em proposições sobre modos e usos do signo-cor pelas marcas.

\subsubsection{Entrelaçamento da base teórica com o trabalho de campo}

Antes e durante o trabalho de campo, foi realizada uma revisão de literatura que abarca estudos qualitativos/interpretativos sobre a cor, marca e consumo, e trabalhos sob a abordagem quantitativa/experimental, também consonantes com a semiótica comportamental de 
Morris. Deste modo, cada questão de pesquisa foi escrutinada sob o conhecimento da Comunicação Visual, do Design, da Mercadologia, da Antropologia e da História, da Psicologia Social e do Comportamento do Consumidor.

Grande parte dos trabalhos referenciados nesta tese vem dessas duas últimas áreas de estudo, em especial no capítulo 2 (modos de significação), pois investigam os efeitos da cor nos processos do raciocínio, da emoção e comportamento humanos ("psicologia das cores"), incluindo o contexto do consumo. O procedimento metodológico desses estudos isola as variáveis manipuladas (e.g. uma única cor testada de cada vez, em um mesmo elemento de identidade, por vez), e frequentemente simula o ambiente social com cores aplicadas a embalagens e logotipos de marcas irreais (e.g. uma montagem fotográfica simulando uma gôndola de supermercado ou embalagens exibidas sobre um fundo branco). O intuito dos experimentos é inferir relações causais entre cores, o pensar, o sentir e o fazer do ser humano.

O controle das variáveis e a utilização de marcas irreais obtêm resultados de alta validade interna, permitindo o avanço da construção da teoria sobre os efeitos das cores. Porém, a validade externa do experimento é diminuída, limitando a generalização dos seus achados para marcas reais e bem estabelecidas no mercado. O mesmo ocorre para a validade ecológica, uma vez que a simulação em laboratório (questões e imagens exibidas em uma tela de computador), reproduz situações diferentes da vida diária dos indivíduos-consumidores.

Quadro 1.2: Entrelaçamento do teórico-experimental com o empírico-interpretativo, na tese.

\begin{tabular}{|c|c|}
\hline $\begin{array}{c}\text { A literatura experimental (dados } \\
\text { secundários) investigou e forneceu: }\end{array}$ & $\begin{array}{c}\text { A pesquisa de campo (dados primários) } \\
\text { investigou e forneceu: }\end{array}$ \\
\hline $\begin{array}{l}\text { - Efeitos da cor aplicada especificamente em } \\
\text { um elemento de identidade de marca, ou } \\
\text { ponto-de-contato. Achados de alta validade } \\
\text { interna. }\end{array}$ & $\begin{array}{c}\text { O A cor permeando diversas manifestações da marca } \\
\text { (logo, embalagem, website, mascote, etc.), de modo } \\
\text { consistente ou não, ao longo do tempo e espaço. } \\
\text { Achados integrativos, olhar rico, holístico, do fenômeno. }\end{array}$ \\
\hline $\begin{array}{l}\text { - Os efeitos causados por uma única cor por } \\
\text { vez: efeitos do amarelo vs. do azul, ou do } \\
\text { vermelho, ou verde, etc. Relações causais } \\
\text { confiavelmente estabelecidas. }\end{array}$ & $\begin{array}{l}\text { O Considera o contexto multicolorido do consumo mesmo } \\
\text { quando a marca em questão é identificada por uma cor } \\
\text { única. Entendimento do fenômeno em ambientes } \\
\text { naturais, na "vida real". }\end{array}$ \\
\hline $\begin{array}{l}\text { - Geralmente testa cores em logotipos, } \\
\text { embalagens, etc. de marcas não existentes, } \\
\text { que não carregam associações ou } \\
\text { julgamentos prévios. Resultados replicáveis } \\
\text { para marcas a serem lançadas. }\end{array}$ & $\begin{array}{l}\text { Observa e analisa materializações marcárias } \\
\text { existentes, sob a interferência das experiências prévias } \\
\text { do público e do ambiente competitivo, com suas } \\
\text { decorrentes ressignificações. Resultados aplicáveis } \\
\text { para marcas reais e já estabelecidas no mercado. }\end{array}$ \\
\hline
\end{tabular}

Fonte: Desenvolvido pela autora.

Assim, relacionando uma base teórica fortemente experimental (embora não exclusivamente), com o trabalho de campo qualitativo-interpretativo (Quadro 1.2), a tese foi 
capaz de integrar o conhecimento das relações casuais entre cor e comportamento humano, com as inter-relações e interferências no contexto de consumo: as influências das marcas concorrentes, dos demais sentidos humanos (olfato, paladar, audição, somestesia) e da multiplicidade de cores e materializações cromáticas de marca, entre outros aspectos.

\subsubsection{Seleção das unidades de análise}

As unidades de análise da tese são manifestações visuais de marca, selecionadas inicialmente por uma amostragem por conveniência. As embalagens, lojas, propagandas, produtos, sites, etc., foram deliberadamente escolhidos pela notoriedade que alcançaram devido ao uso das cores, além de serem produzidos por marcas valiosas, do mercado brasileiro ou internacional. Assim, o corpus da pesquisa foi primeiramente pensado com materiais de expressão e comunicação das seguintes marcas:

- Coca-Cola: marca global de origem americana mundialmente reconhecida pelo vermelho, que ampliou seu portfólio com o apoio da cor prateada, preta e verde;

Itaú

- Itaú: marca de serviços financeiros, brasileira (com operações em outros países do mundo), nacionalmente reconhecida pela cor laranja;

- Louboutin: marca de moda-luxo, surgida na França e hoje global, inicialmente oferecendo sapatos femininos, reconhecidos globalmente pelas solas vermelhas;

M - McDonald's: marca de fast food americana de presença global, por décadas

$M$ reconhecida pela combinação do amarelo (cor principal) com o vermelho, e que atualmente se reposiciona com o apoio do verde como cor secundária, na Europa;

- Vanish: marca de tira-manchas da multinacional Reckitt Benckiser, líder de mercado, identificada (e frequentemente copiada) pela a cor rosa-choque;

- Telstra: marca de serviços de telecomunicação e informação australiana, por décadas reconhecida pelo laranja e azul, e recentemente reposicionada para uma identidade visual mutante na cor (em 6 opções combinatórias);

- Tiffany: marca de joalheira americana (em atuação mundial) que usa, consistentemente, a famosa e patenteada cor "Tiffany Blue" há mais de 170 anos, pela qual é mundialmente reconhecida.

Porém, após o exame de qualificação e com o início das investigações empíricas, percebeu-se que o critério de amostragem limitava a exploração do objeto de pesquisa: estavam sendo considerados apenas materiais produzidos por marcas extremamente valiosas e bem estabelecidas no mercado, que usavam as cores de maneira fixa e consistente em todos os 
pontos-de-contato, ou que passavam por um processo de reposicionamento com a alteração das cores identificadoras (McDonald's, Coca-Cola e Telstra).

Abriu-se então o olhar desta pesquisadora, não mais filtrando os materiais pelo valor da marca ou pela maneira de se utilizar a cor, mas priorizando a pluralidade de características das unidades de análise, passando a identificar como relevantes os novos exemplos e pontos-devista trazidos por cada profissional de marca entrevistado - que indicaram outros especialistas e com eles, mais material pertinente. Pesquisas qualitativas podem ter mudança na amostragem ao longo do processo, na medida em que caminhos se revelam promissores ou malsucedidos para responder as questões centrais do estudo (Kenney, 2010, p. 10).

A estratégia de amostragem foi redesenhada para uma combinação de seleção por conveniência, por busca de variedade e por bola-de-neve (Miles \& Huberman, 1994, p. 28). Assim, os materiais de marca selecionados passaram a configurar um corpus extremamente variável, nos quais as cores são aplicadas fixamente ou variavelmente, produzidas por marcas tradicionais ou recém lançadas.

Muitas das unidades do corpus foram impossíveis de se observar ou vivenciar diretamente: por exemplo, por terem sido produzidas/veiculadas no passado ou em local distante. Porém, por serem exemplos salientes, foram dignas de nota na literatura acadêmica e de mercado, ou no jornalismo especializado em propaganda, design e negócios, o que as tornou acessíveis. Ao final, as unidades de análise selecionadas explicam e ilustram as proposições da tese, concretizando a teoria sobre os modos de significação da cor (capítulo 2), a teoria sobre os usos do signo-cor pela marca (capítulo 3) e a tipologia de discursos cromáticos (capítulo 4), aqui apresentadas.

\subsubsection{Fontes de evidência}

As técnicas de coleta foram escolhidas e executadas em função das proposições de estudo, que direcionaram a atenção ao que é relevante e evitam que o pesquisador se perca na inexequível tentação de coletar "tudo" (Yin, 2003, p. 22). As fontes de evidência utilizadas na tese são descritas a seguir.

\subsubsection{Entrevistas em profundidade}

As entrevistas são "uma das mais importantes fontes de informação em estudos de caso", uma vez que podem fornecer ideias e atalhos relevantes para os pontos principais do 
tema (Yin, 2003, pp. 89-93). O objetivo geral das entrevistas foi obter o ponto-de-vista dos criadores e produtores dos materiais de identidade/comunicação de marca, sobre as práticas e estratégias envolvidas no uso das cores, assim como os efeitos desses usos nos públicos de interesse, os intérpretes.

Entre 16 de fevereiro de 2017 e 26 de janeiro de 2018, foram entrevistados 26 especialistas que trabalham, ou trabalharam, para marcas produtoras de materiais visuais pertinentes à pesquisa, há até três anos da data da entrevista. Do total, 15 entrevistas foram feitas com integrantes de equipes internas das marcas: Carrefour, Coca-Cola, Ford, Glassybaby, Louboutin, McDonald's, New Balance, Nike, Owens Corning, Purple, RED Product, Roam Fitness (2 entrevistados), University of Oregon, Whirlpool (Brastemp e Consul).

As demais 11 entrevistas foram realizadas com profissionais de consultorias nacionais e internacionais, agências criativas e de tendências: Bell Brand Advisors, Epigran-Brand Union (escritório Brasil), Frog Design, FutureBrand, Interbrand (2 entrevistados), Lippincott, Prophet, REBRAND, Siegel+Gale, WGSN (Inglaterra). A cada entrevista, novos casos relevantes de uso da cor pelas marcas eram levantados, entre eles os produzidos pela American Airlines, BP, Hermès, Lincoln, Lululemon, McCafé, NuBank, Petrobrás, T-Mobile, UPS, Vale, YMCA.

Tabela 1.1: Visão geral do perfil dos entrevistados.

\begin{tabular}{|c|c|c|c|c|}
\hline & \multicolumn{2}{|l|}{$\begin{array}{l}\text { Especialistas, gestores } \\
\text { das marcas }\end{array}$} & \multicolumn{2}{|c|}{$\begin{array}{c}\text { Especialistas de agências / consultorias } \\
\text { contratadas pelas marcas }\end{array}$} \\
\hline $\begin{array}{c}\text { ALTO ESCALÃO } \\
(8)\end{array}$ & $\begin{array}{l}\text { - VP de Comunicação; } \\
\text { - CMO - Chefe de Marketing }\end{array}$ & 4 & $\begin{array}{l}\text { - CCO - Chefe de Comunicação; } \\
\text { - CCO - Chefe de Criativo; } \\
\text { - CEO - Chefe Executivo. }\end{array}$ & 4 \\
\hline $\begin{array}{c}\text { DIRETOR }(A) \\
(11)\end{array}$ & $\begin{array}{l}\text { - Geral de Marca; } \\
\text { - De Desenvolvimento de marca; } \\
\text { - Diretor Fundador; } \\
\text { - Chefe de Design } \\
\text { - De Design e Inovação }\end{array}$ & 4 & $\begin{array}{l}\text { - De Estratégia e Naming; } \\
\text { - De Design; } \\
\text { - De Estratégia; } \\
\text { - Sócio-Diretor; } \\
\text { - De Criação; } \\
\text { - De Cor. }\end{array}$ & 7 \\
\hline $\begin{array}{l}\text { GERENTE } \\
\text { (5) }\end{array}$ & $\begin{array}{l}\text { - de Produto; } \\
\text { - de Comunicação de Marca; } \\
\text { - Líder de Marca; } \\
\text { - de Marketing; } \\
\text { - de Inteligência de Mercado }\end{array}$ & 5 & & \\
\hline $\begin{array}{l}\text { ESPECIALISTA, } \\
\text { OPERACIONAL } \\
\text { ou TÉCNICO (2) }\end{array}$ & $\begin{array}{l}\text { - Coordenador de Operações e Projetos; } \\
\text { - Vitrinista/Vendedor }\end{array}$ & 2 & & \\
\hline TOTAL (26) & Entrevistados, equipe interna & 15 & Entrevistados, equipe externa & 11 \\
\hline
\end{tabular}

Fonte: Elaborado pela autora. 
As entrevistas foram realizadas presencialmente (8) ou via Skype (18), todas gravadas em áudio. Ao total, foram aproximadamente 15 horas de gravação: a entrevista mais curta durou cerca de 12 minutos, a mais longa, 63 minutos. As conversas foram realizadas sob um roteiro semiestruturado (ver Apêndice A e B), conduzidas em português ou inglês (no idioma do respondente) e transcritas integralmente por esta pesquisadora. Foram entrevistados colaboradores de diferentes níveis hierárquicos (Tabela 1.1), a fim de se obter distintas perspectivas, desde o âmbito técnico-operacional (2), passando aos níveis de gerência (5) e diretoria (11), até o mais alto escalão executivo de vice-presidência e C-level (8).

\subsubsection{Visitas de observação participante}

Na observação participante, o pesquisador assume uma postura ativa nas situações, vivenciando e "percebendo a realidade do ponto de vista de dentro do caso estudado" (Yin, 2003, p. 94). As visitas foram realizadas em lojas-conceito e pontos-de-venda multimarcas, seguindo um protocolo de campo (ver Apêndice C), com anotações textuais e verbais (com o uso de um gravador) sobre artefatos, acontecimentos e comportamentos, e quando permitido, com levantamento fotográfico / gravação de vídeo.

No total, foram visitados 35 ambientes físicos de marca, a maioria deles um espaço exclusivo, proprietário (exceção a uma das visitas à Louboutin, realizada na loja multimarcas Saks Fifth Avenue, em Nova York). Os ambientes visitados pertencem às seguintes marcas: Carrefour (2), Glassybaby (2), Harley Davidson (1), Hermès (1), iGirl (1), Itaú (2), Lego (1), Louboutin (3), Lululemon (1), M\&Ms (1), McDonald's (3), Nespresso (2), Nike (3), RED Product (1), Sephora (2), Tiffany (2), T-Mobile (4), University of Oregon (1), Victoria's Secret (3), Victoria's Secret Pink (3). As visitas se iniciaram em setembro de 2016, nos Estados Unidos, e seguiram até final de 2017, em São Paulo.

\subsubsection{Coleta de artefatos físicos e documentação fotográfica}

A expectativa de que entrevistados fornecessem relatórios ou resultados de pesquisa de marketing foi quebrada logo nas primeiras conversas: os dados sobre comunicação e design de marca e a mensuração das respostas dos consumidores são altamente sigilosos. Deste modo, muitas das informações complementares sobre campanhas e ativações de marca discutidas pelos entrevistados, foram obtidas em revistas e jornais especializados em comunicação, design e negócios, sites e blogs de consultorias de branding. Em alguns casos, os documentos foram 
conseguidos em canais oficiais das marcas, como perfis das redes sociais ou seção especial dentro do site (com materiais de comunicação, press releases, etc.).

A coleta de artefatos físicos ${ }^{15}$ e a documentação fotográfica foi possível em visitas de observação e nas entrevistas presenciais. Ao final, os artefatos coletados - embalagens, catálogos, imagem da interface gráfica de sites e aplicativos ("foto de tela"), propagandas e fotos de lojas e de eventos - diretamente ou por via secundária, foram analisados, categorizados, e fazem parte do embasamento das teorias e da tipologia propostas.

\subsubsection{Análise dos dados e resultado final}

Na investigação qualitativa, a análise dos dados é um processo cíclico e interativo com a fase de coleta, formada pelas atividades gerais de redução dos dados (selecionar, simplificar, abstrair, transformar), organização/apresentação dos dados (montagem resumida, compacta e esclarecedora), interpretação e verificação conclusiva (encontrar regularidades e padrões, revisar os dados coletados frente às conclusões) (Miles \& Huberman, 1994, p. 12).

O caminho analítico percorrido é apresentado a seguir, desde a fase inicial de coleta até o desenvolvimento final da tipologia de discursos cromáticos de marca. Organizada em quatro etapas, a síntese de trabalho segue o esquema desenhado por Bonoma (1985) para estudos-decaso mercadológicos, com quatro estágios inter-relacionados e não hierarquizados:

1) Deriva: nessa etapa os modos de significação e os usos da cor pelas marcas foram explorados e delineados com base nas teorias de Morris (1946) e com a interligação dos conceitos teóricos da literatura interdisciplinar, dos conhecimentos da prática de mercado e da sensibilização da pesquisadora, advindos do trabalho de campo;

2) Design (ou desenho): nesse estágio definiu-se os modos e usos do signo-cor. Na medida em que eram selecionadas, as manifestações visuais do corpus foram classificadas, ilustrando, detalhando e/ou provocando uma readaptação, das categorias classificatórias estipuladas na etapa anterior. As categorias serviram como casos pré-estabelecidos (4 categorias de modo e 4 categorias de uso da cor). O desenho da tipologia dos discursos cromáticos na marca foi iniciado;

3) Previsão: nesta fase a tipologia dos discursos cromáticos foi propriamente

\footnotetext{
${ }^{15}$ Os materiais coletados estarão expostos para a banca avaliadora na cerimônia de defesa da tese.
} 
desenvolvida, pelo cruzamento dos dois eixos (4 modos x 4 usos da cor na marca). Para um melhor entendimento dos conceitos classificatórios e dos parâmetros de generalizações, as 16 variações tipológicas possíveis foram testadas por meio da análise materiais de marca já discutidos (apenas sobre o modo ou apenas sobre o uso da cor) nos capítulos anteriores;

4) Refutação e verificação final: na última etapa, quatro dos 16 possíveis tipos discursivos não confirmados foram integrados em um único (ao longo do eixo vertical do uso sistêmico). A tipologia final foi definida com 13 discursos cromáticos (Quadro 1.3). Novos materiais de marca foram analisados e classificados, servindo com exemplos ideais para os tipos discursivos - que foram tratados como um estudo-de-13-casos múltiplos. Os discursos cromáticos se comprovaram inter-relacionados e não excludentes.

Quadro 1.3: Os principais tipos de discursos cromáticos de marca.

\begin{tabular}{|c|c|c|c|c|}
\hline $\begin{array}{l}\text { USOS DO } \\
\text { SIGNO-COR } \\
\text { MODOS DO } \\
\text { SIGNO-COR }\end{array}$ & INFORMATIVO & AVALIATIVO & INCITIVO & SISTÊMICO \\
\hline DESIGNATIVO & $\begin{array}{l}\text { Cor-Assinatura } \\
\text { designativo-informativo }\end{array}$ & $\begin{array}{c}\text { Arco-Íris } \\
\text { designativo-avaliativo }\end{array}$ & $\begin{array}{c}\text { Cor-Código } \\
\text { designativo-incitivo }\end{array}$ & \multirow{4}{*}{$\begin{array}{l}\text { Cor-Estrutura } \\
\text { discurso } \\
\text { multimodal-sistêmico }\end{array}$} \\
\hline APRECIATIVO & $\begin{array}{l}\text { Cor-Mito } \\
\text { apreciativo-informativo }\end{array}$ & $\begin{array}{c}\text { Cor-Alegoria } \\
\text { apreciativo-avaliativo }\end{array}$ & $\begin{array}{l}\text { Cor-da-Moda } \\
\text { apreciativo-incitivo }\end{array}$ & \\
\hline PRESCRITIVO & $\begin{array}{l}\text { Manual-da-Cor } \\
\text { prescritivo-informativo }\end{array}$ & $\begin{array}{c}\text { Cor-do-Ano } \\
\text { prescritivo-avaliativo }\end{array}$ & $\begin{array}{l}\text { Cor-Mania } \\
\text { prescritivo-incitivo }\end{array}$ & \\
\hline $\begin{array}{l}\text { TRANS- } \\
\text { FORMATIVO }\end{array}$ & $\begin{array}{l}\text { Cor-Disruptiva } \\
\text { transformativo-informativo }\end{array}$ & $\begin{array}{l}\text { Cor-Dialógica } \\
\text { transformativo-avaliativo }\end{array}$ & $\begin{array}{l}\text { Cor-Criação } \\
\text { transformativo-incitivo }\end{array}$ & \\
\hline
\end{tabular}

Fonte: Desenvolvido pela autora.

Para cada um dos discursos cromáticos de marca foi criado um termo ilustrativo, seguindo a prática realizada por Morris na tipologia discursiva original. Os tipos podem ser agrupados em função dos quatro usos que uma marca pode fazer das cores, ao aplicá-las em suas manifestações visuais, ou podem ser olhados conforme o modo proeminente da cor significar uma marca, em uma leitura horizontal.

A tipologia foi exposta acima apenas para uma ideia geral do trabalho investigativo de quatro anos de doutoramento. Nos próximos três capítulos, as teorias dos modos e dos usos do signo-cor e a tipologia dos discursos cromáticos de marca são apresentadas e verificadas detalhadamente. 


\section{Modos de significação da cor para a marca}

Nesse capítulo, a teoria dos modos (ou dimensões) de significação dos signos, de Morris, é repensada para os domínios da cor e da marca. Aqui, o intuito é definir os modos que as cores significam as marcas, para seus públicos, por meio das cinco questões de pesquisa já apresentadas (ver seção 0 da tese) e resumidas no Quadro 2.1.

Morris (1946, pp. 60-61) estipulou cinco modos de um signo operar, ou significar um objeto ao intérprete: modo identificativo (localiza o objeto para o intérprete), modo designativo* (designa o objeto para o intérprete), modo apreciativo* (evoca apreciações sobre o objeto, no intérprete), modo prescritivo* (dispõe o intérprete a agir em relação ao objeto), e modo formativo (altera as disposições, os interpretantes previamente estipulados).

Quadro 2.1: Questões de pesquisa sobre os modos de significação das cores.

\begin{tabular}{|c|c|c|c|}
\hline \multicolumn{3}{|c|}{$\begin{array}{l}\text { QUESTÕES DE PESQUISA SOBRE OS MODOS DAS CORES } \\
\text { SIGNIFICAREM MARCAS, PARA SEUS PÚBLICOS }\end{array}$} & $\begin{array}{l}\text { MODO DE SIGNIFICAÇÃO } \\
\text { CORRESPONDENTE EM } \\
\text { MORRIS (1946) }\end{array}$ \\
\hline \multirow{5}{*}{$\begin{array}{l}\text { A cor opera } \\
\text { como signo }\end{array}$} & Q1 & $\begin{array}{l}\text {... uma disposição para localizar a marca em um } \\
\text { tempo/espaço específico? }\end{array}$ & $\begin{array}{l}\text { MODO } \\
\text { IDENTIFICATIVO }\end{array}$ \\
\hline & Q2 & $\begin{array}{l}\text {... uma disposição para reagir como se a marca } \\
\text { tivesse propriedades/ características específicas? }\end{array}$ & $\begin{array}{c}\text { MODO } \\
\text { DESIGNATIVO* }\end{array}$ \\
\hline & Q3 & $\begin{array}{l}\text {... uma disposição positiva/negativa em } \\
\text { relação à marca? }\end{array}$ & $\begin{array}{l}\text { MODO } \\
\text { APRECIATIVO* }\end{array}$ \\
\hline & Q4 & ... uma disposição para agir em relação à marca? & $\begin{array}{l}\text { MODO } \\
\text { PRESCRITIVO* }\end{array}$ \\
\hline & Q5 & $\begin{array}{l}\text {... uma disposição para alterar as disposições } \\
\text { prévias em relação à marca? }\end{array}$ & $\begin{array}{l}\text { MODO } \\
\text { FORMATIVO }\end{array}$ \\
\hline
\end{tabular}

Fonte: Desenvolvido pela autora. * Principais modos de significação, segundo Morris (1946).

Investigar os modos em que as cores significam marcas, implica que a cor opera como signo marcário, um "signo-cor". Pelo olhar da semiótica, a cor pode ser signo de um fenômeno 
físico, de um mecanismo fisiológico, de uma associação psicológica, na medida em que a cor os representa, ou os substitui em alguns aspectos, para alguém (Caivano, 1998). Essa capacidade cromática de significar é amplamente aceita em diversos contextos, desde o ambiente acadêmico, revistas de negócio, até posts do Facebook (Figura 2.1), seja embasada em pesquisas científicas, gosto pessoal, senso comum ou crendices populares (Adams \& Osgood, 1973; Adnews, 2017; Crozier, 1999; Gage, 1999; Guimarães, 2000; Heller, 2004; Kress \& Van Leeuwen, 2002; Pedrosa, 2008, entre outros).

Figura 2.1: Os "significado das cores" em (a) um blog de design expondo o efeito das cores no consumidor, e (b) site da Valisere, sobre a cor ideal da calcinha, para o reveillon 2016.

(a)

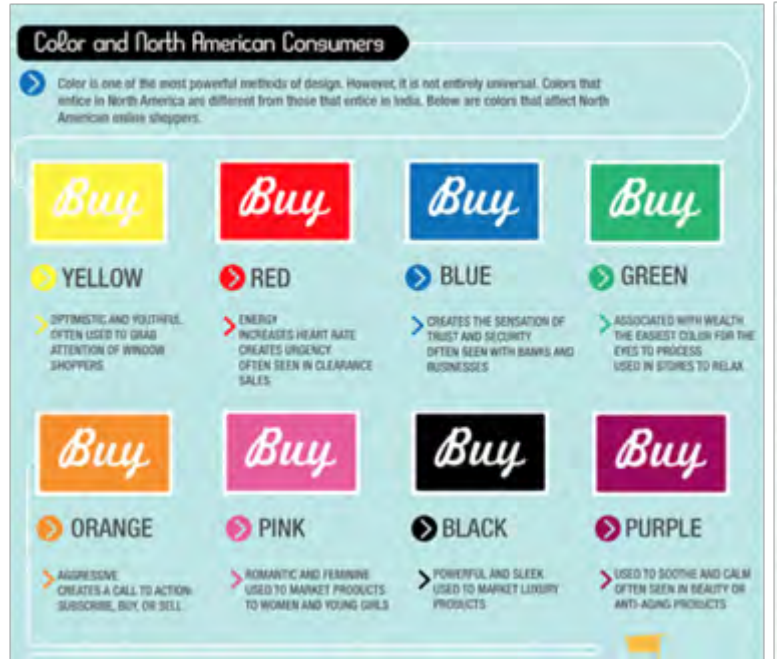

(b)

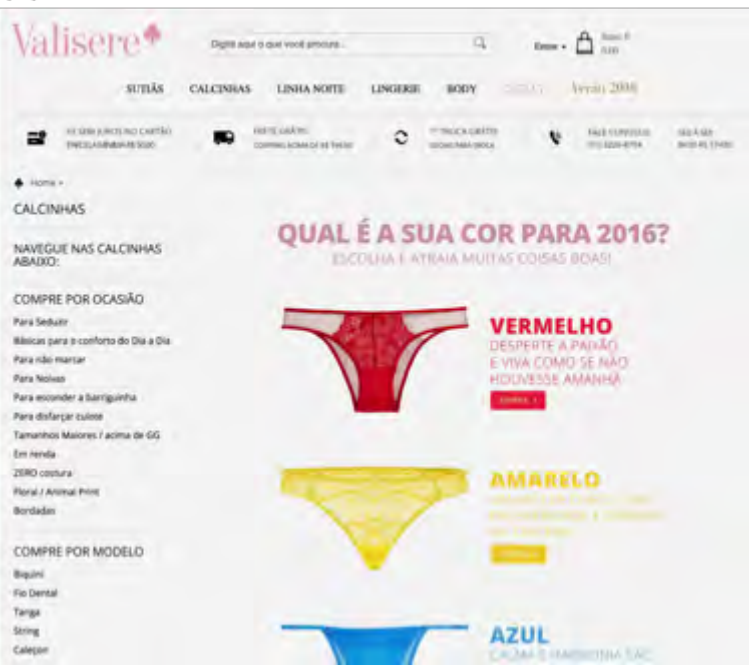

Fontes: (a) Blog Kissmetrics (Kelly, 2010); (b) Site da marca (Valisere, 2015).

Na visão comportamental Morrisiana, um animal tende a responder às evocações de um signo, de um modo ou de outro, por herança ou por aprendizado (Morris, 1946, p. 83). Em consonância, a Psicologia Social explica a formação dos significados das cores por duas fontes, não excludentes e mutualmente operantes: as inclinações biológicas e o aprendizado social (Elliot \& Maier, 2012).

O aprendizado social se dá pelo condicionamento clássico, pelo pareamento contínuo explícito e implícito, de cores com conceitos específicos. Repetido ao longo do tempo, o pareamento constrói fortes associações capazes de influenciar emoções, pensamentos e comportamentos. As predisposições biológicas às cores são as respostas fisiológicas que participaram da evolução da visão e contribuíram para a sobrevivência das espécies, como por exemplo, escolher e comer frutas maduras - e avermelhadas. Assim, enquanto as respostas fisiológicas às cores podem ser observadas em seres humanos de diferentes culturas ao redor do mundo (significados universais), os significados cromáticos aprendidos são altamente 
dependentes do contexto (Labrecque, Patrick, \& Milne, 2013). As respostas atualizadas, em contínua transformação, são derivadas da interação das tendências fisiobiológicas e dos aprendizados (práticas sociais e culturais) ao longo do tempo (Elliot \& Maier, 2012).

A universalidade dos significados das cores é uma discussão polêmica. Pastoureau, historiador da cor, explicita as contradições do tema em seus trabalhos. $\mathrm{O}$ autor sempre definiu a cor como um complexo construto cultural, um fenômeno social que resiste a generalizações (Pastoureau, 2001, p. 8), cujas respostas emocionais são dependentes do contexto e da bagagem sensorial e cultural de quem as vê (Pastoureau, 2014, p. 202). Apesar de confessadamente nunca ter acreditado em um sistema simbólico universal das cores, em qualquer época ou lugar, recentemente foi "obrigado a reconhecer que alguns referentes cromáticos são encontrados em quase todas as sociedades" (Pastoureau, 2009, p. 24), aludindo especificamente às associações entre vegetação e a cor verde, luz e o branco, noite e o preto (ambígua, porém sempre mais amedrontadora do que reconfortante), fogo e sangue para a cor vermelha (Pastoureau, 2017, pp. 22-24).

Na dimensão semântica das cores e de outros sistemas semióticos, pictogramas por exemplo, as regras e convenções simbólicas são "dinâmicas e passíveis de transformação" haja vista que são hábitos de conduta estabelecidos e modificados pelos usos sociais (S. Souza, 1992, p. 76). Por essa aproximação social, semiótica, histórica e antropológica e psicológica das cores, esta tese parte da premissa que não existem significados fixos e universais das cores para as marcas. Ao contrário, a marca (seus comunicadores, criadores e gestores) pode decidir vincularse ou não, às associações pré-determinadas ou estereotipadas, no seu contexto cultural e competitivo - decisão essa que traz implicações na significação e no uso das cores pelas marcas, tratadas neste e no próximo capítulo.

Ilustrando o dinamismo e flexibilidade sígnica das cores operando em função do contexto, Chaves (2014) discorre sobre a cor vermelha, que pode significar "perigo, fogo, paixão, sangue, comunismo, o próprio diabo, e sabe se lá quantas coisas mais" e que também é utilizada eficientemente para identificar Coca-Cola, Avis, Marlboro, o Partido Comunista, o Peru, o Canadá, ou os diabos vermelhos do clube argentino de futebol Atlético Independiente de Avellaneda, na grande Buenos Aires.

Na classificação de Morris, a nomenclatura cromática, como os termos "preto", branco", etc., são signos primariamente designativos, por significarem propriedades observáveis do objeto que denotam. Porém, explica ele, "preto" (e os demais nomes de cores) pode também operar em modo apreciativo ou prescritivo, a depender da situação, e "há evidências que certos 
termos têm significação nas três dimensões" (Morris, 1964, pp. 4-5). Seguindo essa premissa, apesar da separação dos modos de significação para fins de estudo, esta tese propõe que uma cor (ou uma combinação de cores) opera em mais de um modo simultaneamente: por exemplo, pode caracterizar, induzir a avaliações negativas ou positivas e provocar ações em relação a uma marca. Além disso, os modos de significação das cores são, como os modos de significação de outros signos, independentes (um modo pode ocorrer sem o outro), mas ao mesmo tempo interdependentes e complementares (Morris, 1946, p. 89).

A seguir, os cinco modos de significação de um signo, propostos por Morris (1946), serão discutidos e repensados - ou rejeitados - para a cor significando marcas. As discussões cotejam a teoria de Morris com estudos acadêmicos, casos do mercado e depoimentos de especialistas em marcas, comunicação, design e cor.

QUESTÃO 1 DA TESE:

\subsection{A cor localiza uma marca em um tempo/espaço específico?}

De acordo com Morris, o modo identificativo de significação é o modo mínimo, embora genuíno, em que um signo significa algo: os identificadores (identifiors) significam locais espaço-temporais (locata), como apontar com o dedo, dizer as horas ou um endereço, como os termos "isto", "agora", e as coordenadas cartesianas "x,y". (Morris, 1946, p. 76). Signos identificadores apenas localizam, não designam, apreciam, nem prescrevem comportamentos. Ajustando e renomeando o modo identificativo de Morris, tem-se a primeira proposição sobre os modos da cor significar uma marca, a seus públicos:

\section{Proposição 1: a cor significa a marca no modo atentivo (attentive mode)}

Uma cor (ou uma combinação de cores), aplicada em elementos e materiais marcários, significa uma marca no modo atentivo na medida em que torna suas materializações visualmente percebidas no espaço bi/tridimensional. É o modo mais básico e uma condição prévia para que a(s) cor(es) signifique(m) a marca nos modos consecutivos.

No atual contexto competitivo, garantir a visibilidade e chamar a atenção ao logotipo, embalagem ou material promocional, é fator crucial para as marcas, especialmente considerando o domínio visual sobre outras modalidades perceptivas (M. I. Posner, Nissen, \& 
Klein, 1976), e a era em que vivemos - da economia da atenção e da cultura da informação visual (Schroeder, 2002). Uma marca necessita ser percebida, ter uma manifestação visível e permanente no espaço e no tempo, uma vez que "o homem é um animal ótico", cuja percepção de mundo e conhecimento se dá predominantemente no visual (Costa, 2011, p. 25). Por implicar os conceitos básicos da percepção visual, como a legibilidade e contrastaste necessários para uma materialização marcária ser visível, a dimensão atentiva da cor é pensada desde os estágios mais iniciais da concepção de uma marca:

Quando a empresa começou, em 2006, o Bono [vocalista do U2] e o Bob Sheppard queriam que a marca fosse muito aparente, então o vermelho foi escolhido e aplicado nas propagandas e nos produtos. Nos últimos dois anos nós paramos com isso, porque queremos que as empresas que não usam o vermelho possam também se envolver. .... Agora não precisa ser tudo vermelho, mas as companhias querem aparecer, querem o vermelho. (Depoimento de especialista - RED)

\begin{abstract}
A maioria das pessoas pensa primeiro nas cores..., a partir do aspecto da atenção, como posso obter a maior atenção? ... . Há tantas marcas em vermelho porque acham que é uma maneira de chamar a atenção. Mas há tantas em vermelho que estão apenas seguindo uma norma. Por exemplo, onde eu moro aqui em Salt Lake City... tem na estrada um lugar com restaurantes e há uma grande sinalização com todos os 15 restaurantes. Literalmente, 14 dos logotipos são vermelhos, e todos tentam se destacar... Se uma marca não se destaca, as pessoas não clicam em seus anúncios e você não ganha dinheiro. (Depoimento de especialista - Purple)
\end{abstract}

Antes de identificarem, avaliarem ou comprarem uma marca, os consumidores filtram informação, atribuem atenção e comparam os elementos de informação visual de uma marca e entre marcas concorrentes (Pieters \& Warlop, 1999). Nas redes sociais, nas propagandas, nas lojas, entre incontáveis produtos, sons, cheiros, movimentos, ícones, alertas de mensagens, o olhar dos indivíduos-consumidores pode ser capturado por uma marca quando ela se salienta visualmente do seu contexto por meio da cor. $\mathrm{O}$ modo atentivo ${ }^{16}$ (attentive mode), aqui

\footnotetext{
16 O termo "atentivo" (attentive) foi usado para substituir o termo original de Morris (1946), modo "identificativo" (identificative), pela autora considerar que esse poderia ser confundido com o conceito de "identidade de marca", fundamental nos estudos e práticas das marcas (criação, gestão, comunicação, etc.).
} 
proposto, reporta-se à capacidade da cor em tornar visível e capturar a atenção para as materializações marcárias.

A sobrevivência de uma marca pode depender dos consumidores localizarem suas ofertas pela cor, no site de vendas ou na prateleira do supermercado (processo perceptual), considerando também se experimentaram a marca ou viram anteriormente (e memorizaram) uma propaganda da marca, por exemplo (processo cognitivo). Essa característica dual (perceptual/cognitiva) do processo de atenção visual, reforça a proposição da cor como um signo atentivo da marca. A atenção visual não é apenas uma resposta involuntária a uma saliência, a um contraste visual, mas também uma resposta à combinação entre os estímulos visuais dos objetos salientes do momento e a carga sígnica desses objetos, anteriormente estabelecida - a marca, seus competidores, o entorno, etc. (Henderson, Brockmole, Castelhano, \& Mack, 2007).

As interações entre as cores da marca e as do seu entorno envolvem importantes fenômenos perceptuais, como por exemplo, o efeito do contraste simultâneo, já descrito desde Goethe ([1810] 1993) e Chevreul (1860): cores idênticas são percebidas como diferentes, em função da cor do fundo sobre a qual estão inseridas. Esse e outros efeitos, de natureza sintática da cor e frequentemente trabalhados sob o olhar da Comunicação Visual e do Design, são denominados como "interação das cores” (Albers, 1963):

Na percepção visual, uma cor quase nunca é vista como realmente é como é fisicamente. Este fato torna a cor o meio mais relativo da arte. $\cdots$

Primeiro, deve-se saber que uma mesma cor evoca inúmeras leituras. Em vez de aplicar mecanicamente ou simplesmente implicando leis e regras de harmonia de cores, distintos efeitos de cores são produzidos - através do reconhecimento da interação das cores - fazendo, por exemplo, duas cores muito diferentes parecem iguais ou quase iguais. ${ }^{17}$ (Albers, 1963, p. 1)

Esses fenômenos perceptuais são relevantes uma vez que a cor evoca diferentes disposições no intérprete a depender, entre outras coisas, de como ela é efetivamente percebida. Por exemplo, manifestações cromáticas perceptualmente idênticas advindas de marcas

\footnotetext{
17 In visual perception, a color is almost never seen as it really is - as it physically is. This fact makes color the most relative medium in art. [...] First, it should be learned that one and the same color evokes innumerable readings. Instead of mechanically applying or merely implying laws and rules of color harmony, distinct color effects are produced-through recognition of the interaction of color-by making, for instance, two very different colors look alike, or nearly alike.
} 
diferentes, podem confundir seus públicos, provocando efeitos de sentido incoerentes com os valores que querem comunicar. Em outro exemplo, uma mesma cor pode evocar interpretantes totalmente distintos conforme a combinação cromática em que está participando (Figura 2.2):

A interação das cores é tão importante como a cor por si mesma. Se você pegar um millennial pink e colocá-lo com o preto ou com o carvão escuro, fica muito diferente do que com o verde. (Depoimento de especialista - WGSN)

Eu realmente acredito que há algo poderoso em torno de uma combinação de cores, que muda o significado ao estarem juntas... uma marca pode fazer muito mais do que atualmente faz, para ser distintiva. (Depoimento de especialista -FutureBrand)

Figura 2.2: Os diferentes efeitos da combinação do millennial pink, a cor da moda de 2017, com (a) o preto e com (b) o verde.

(a)

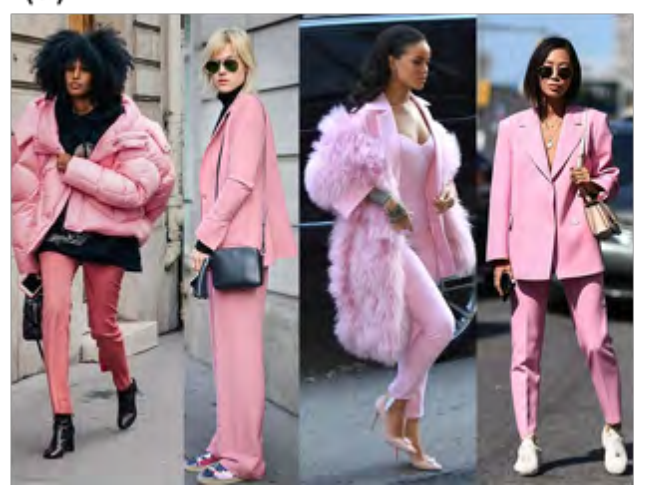

(b)

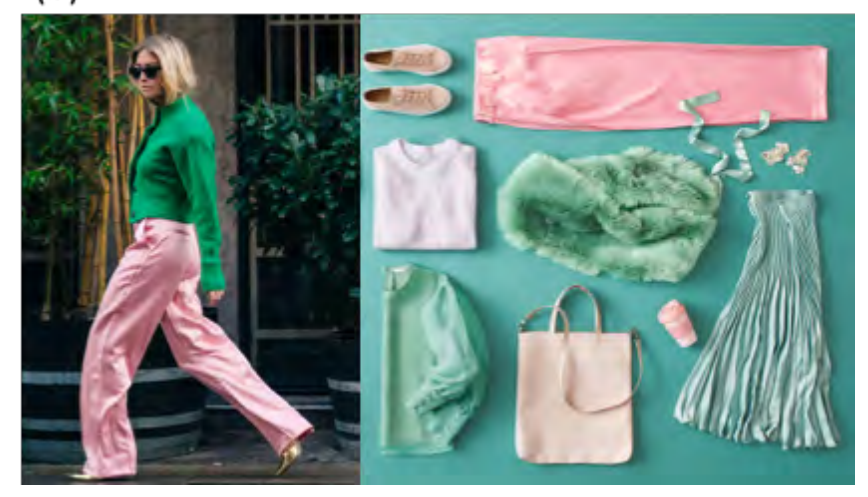

Fontes: (a) Plataforma Shopological (2017); (b) H\&M Magazine (2017, 2018). Último acesso em 31/01/2018.

Além disso, com o tempo, o ser humano tende a prestar menos atenção ou a ignorar o que vê regularmente (Pieters, Rosbergen, \& Wedel, 1999). Assim, cores similares (de fato ou perceptualmente) aplicadas repetidamente pelos competidores - ou exaustivamente por uma mesma empresa - têm capacidade reduzida em captar a atenção (modo atentivo), e consequentemente de caracterizar (modo designativo), de favorecer (modo apreciativo) ou de provocar uma ação (modo prescritivo) para as marcas.

Apesar de Morris afirmar que os signos de localização espacial ou temporal provocam uma disposição (não apenas uma reação involuntária) e alteram o comportamento do intérprete, ele não utilizou esse modo de significação na sua tipologia dos discursos sígnicos. Conforme já discutido, um signo que simplesmente localiza o objeto possui um "status de signo mínimo" e é 
simplesmente um estimulo preparatório, "um dispositivo para chamar a atenção para algo" (Morris, 1946, pp. 76-77).

Apesar da condição sígnica "mínima", o modo atentivo da cor é fundamental para o processo sígnico cromático, um pré-requisito para que o signo-cor opere nos demais modos: em primeiro lugar, uma marca deve ser percebida visualmente. Chamar a atenção visual implica na saliência visual de marca, o quanto uma marca se destaca visualmente das concorrentes (Lans, Pieters, \& Wedel, 2008), e influencia diretamente a sua identificação e conhecimento por parte dos públicos de interesse (ver capítulo 3 , sobre os usos da cor).

Incluindo a dimensão visual e para além dela, quanto mais a marca é saliente, ou seja, quanto maior "a propensão de uma marca se destacar na memória dos consumidores em situações de escolha ou compra", maior a probabilidade da marca ser avaliada positivamente (Romaniuk \& Sharp, 2004). A saliência visual de marca aumenta a probabilidade de uma marca ser considerada, escolhida e consumida (e.g. (Milosavljevic, Navalpakkam, Koch, \& Rangel, 2012; Nedungadi, 1990), evidenciando assim, a influência do modo atentivo nos demais modos da cor significar uma marca.

\section{QUESTÃO 2 DA TESE:}

\subsection{A cor caracteriza uma marca?}

Os nomes de cores são classificados originalmente por Morris como signos designadores: significam "características (discriminata) de um objeto ou situação que o distinguem de outras coisas". As palavras "azul", "vermelho" ou "verde" são signos designadores-de-característica, uma vez que designam qualidade. Termos como "mulher", “céu” ou "amor" são designadores-de-objeto, designam "coisas" (Morris, 1946, pp. 77-78). Repensando o modo designativo de Morris, tem-se a segunda proposição sobre os modos da cor significar uma marca, a seus públicos:

\section{Proposição 2: a cor significa a marca no modo designativo (designative mode)}

Uma cor (ou uma combinação de cores), aplicada em elementos e materiais marcários, significa uma marca no modo designativo ao caracterizar cromaticamente uma marca. As cores podem operar como signo "designador-de-marca" (quando designam a cor da marca), evocando nos consumidores as características de uma marca; ou como 
"designador-de-atributo" (quando designam propriedades comuns da categoria), caracterizando ingredientes, sabores e aromas, funções, benefícios, públicos-alvo, personalidades, etc., da marca.

\section{O signo-cor como designador-de-marca}

Cores, formas, grafismos, estampas, materiais e acabamentos, são elementos estéticos visuais (Schmitt, Simonson, \& Marcus, 1995), manifestações significantes que participam da "estética da marca" quando incorporados aos elementos de identidade e de comunicação marcários (produto, logotipo, embalagem, propaganda, etc.) de modo "coerente, distinto e persistente no tempo" (Semprini, 2000, p. 173). Não raramente, o estilo visual é o fator decisivo para uma marca ser percebida como única e pode ser um imenso patrimônio financeiro da organização, auxiliando na comunicação dos seus princípios centrais (Olins, 1990; Ravasi \& Lojacono, 2005).

A cor, componente básico da comunicação visual e uma das mais penetrantes experiências (Dondis, 1991, p. 64), permeia toda a existência visual da marca e pode ser seu principal elemento identificador (Schmitt \& Simonson, 2002, p. 109). Apesar dessa onipresença na mediação (e midiatização), a cor é incapaz de especificar autonomamente uma marca: é necessário que o intérprete visualize a cor aplicada no logotipo, ou em uma embalagem, ou que seja informado sobre a categoria do produto ou serviço em questão.

A falta de autonomia em identificar uma marca não desqualifica a cor como signo designador-de-marca. Imaginando-se em uma loja de móveis, com vários produtos à venda, dizer apenas o signo verbal "cadeira" (um designador-de-objeto, segundo Morris) não designa obrigatoriamente um único objeto, a não ser que exista apenas uma cadeira exposta em todo o ambiente de compra. Mas, mesmo assim, "cadeira” designa a característica de um objeto. Podem ser necessários outros signos verbais e não verbais, como apontar com o dedo (signo identificador, localizando a peça), e/ou signos designadores-de-características, como "vermelha", "alta", "arredondada", para evocar no intérprete a designação do objeto específico. Do mesmo modo, para identificar visualmente uma marca, além do signo-cor são necessários outros signos visuais e verbais (o nome, o logotipo, propaganda, etc.).

Para exemplificar a cor como signo designador-de-marca, considere-se os bancos de varejo atuantes no sistema financeiro brasileiro (abrangência nacional) e suas respectivas cores: Itaú na cor laranja (azul como secundária), Banco do Brasil em amarelo e azul, Caixa Econômica Federal em azul e laranja, Bradesco e Santander em vermelho (Figura 2.3). 
Figura 2.3: Logotipos dos cinco bancos de varejo do Brasil com atuação nacional.
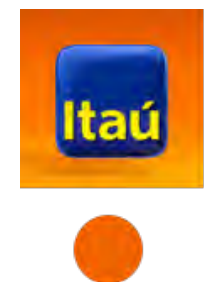
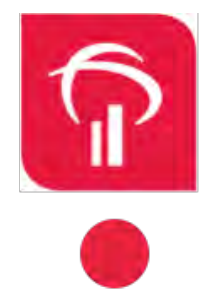
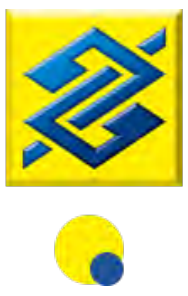
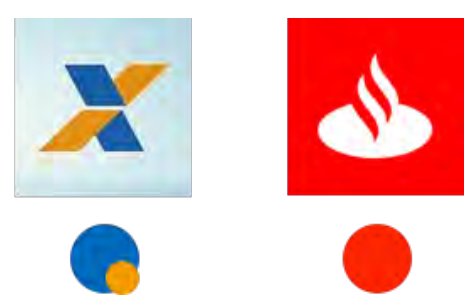

Fontes: Páginas oficiais no Facebook, de cada banco. Último acesso em 01/12/2017.

Nesse contexto competitivo, o laranja designa especificamente o Itaú, enquanto a cor vermelha, em tonalidades levemente diferentes, designa duas marcas - Bradesco e Santander -, embora careça dos logotipos para que se possa distingui-las visualmente.

O poder sígnico da cor em designar uma marca é amplamente aceito e explorado pelos especialistas de marcas. Ao significar a marca consistentemente em todos os pontos-decontato e ao longo do tempo, eles acreditam que a cor provoca a lembrança, familiaridade e reconhecimento marcário, nos públicos:

Quando você olha para certas marcas, elas são muito associadas a uma cor, o laranja de Hermes, o azul da Tiffany e, claro, as solas da Louboutin.... Para a Louboutin, a cor da sola é um logotipo, ... uma das únicas marcas que você pode reconhecer somente pela cor. Eu acho que isso muito importante... é muito memorável quando você a associa com uma marca. (Depoimento de especialista - Louboutin)

Normalmente, existe uma cor predominante na marca com consistência de valor. As pessoas querem sentir que, todas as vezes que experimentam essa marca, vão ter o que esperam.... Quando você pensa "lkea", você sabe que é azul e o amarelo, mas provavelmente é o amarelo que se destaca mais. Existe um reconhecimento imediato, é uma maneira fácil de recordar uma característica positiva da marca. Portanto, ter uma cor predominante é importante, embora geralmente as marcas possuam combinações [de cor]. (Depoimento de especialista - Interbrand)

Porém, a cor designa a marca e seus os pontos-de-contato também quando é mutável. Cada vez mais frequente, a inconstância cromática está em sintonia com a fluidez e ambiguidade características da pós-modernidade (Harvey, 1992), da modernidade líquida (Bauman, 2001) ou dos tempos hipermodernos (Lipovetsky \& Sebastien, 2004), refletindo a natureza múltipla e dinâmica do conceito de identidade das ciências sociais: as marcas devem ser entendidas em um "contínuo processo de identificação", articuladas, construídas e 
contestadas no contexto sociocultural e nas relações com seus públicos (Csaba \& Bengtsson, 2006, p. 119).

As marcas que se expressam visualmente de maneira flexível, em diferentes níveis de alteração - de uma mudança total até as menos radicais e com número limitado de variações são denominadas marcas mutantes (Kreutz, 2007) ou cambiantes (Kopp, 2002). Quando a mutabilidade da identidade visual ocorre exclusivamente no elemento cromático, propõe-se aqui que sejam denominadas marcas mutantes, ou cambiantes, na cor.

Existem dois exemplos de marcas mutantes no setor de telecomunicações do Brasil. Um deles é a Vivo (Figura 2.4), mutante apenas na cor desde o seu lançamento em 2003. O manual de identidade da marca especifica cinco cores como oficiais - roxo, azul, verde, laranja e vermelho (Vivo, 2012) -, mas na prática, a cor vermelha não é utilizada para que não se remeta à concorrente Claro, para quem a cor é utilizada na função informativa de identidade.

Figura 2.4: As cores designadoras da marca Vivo.

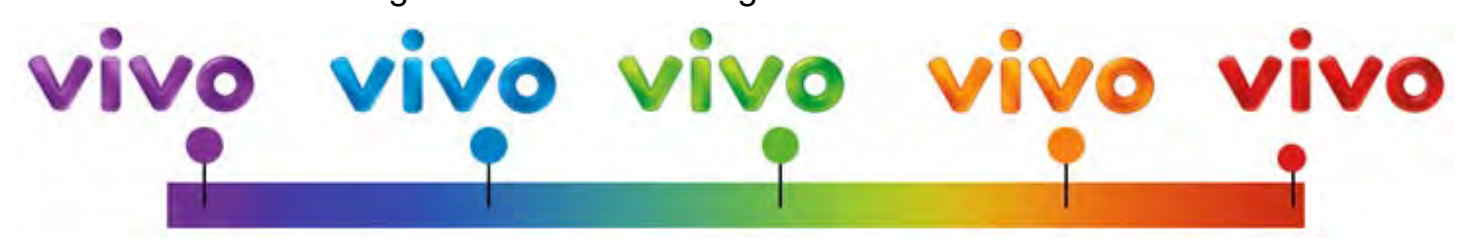

Fonte: Manual da marca Vivo (2012).

O outro exemplo, mais recente, é o da Oi (Figura 2.5). Em 2016, a marca passou a ser mutante também na cor, com três tipos de combinações possíveis de cores, arranjadas em dégradé. O logotipo anterior era mutante apenas na forma (seis versões), pois o amarelo alaranjado designava a marca de maneira fixa.

Figura 2.5: (a) Antigos (2011) e (b) novos (2016) logotipos da Oi.

(a)

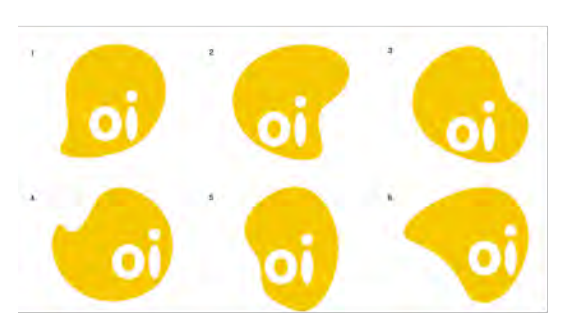

(b)

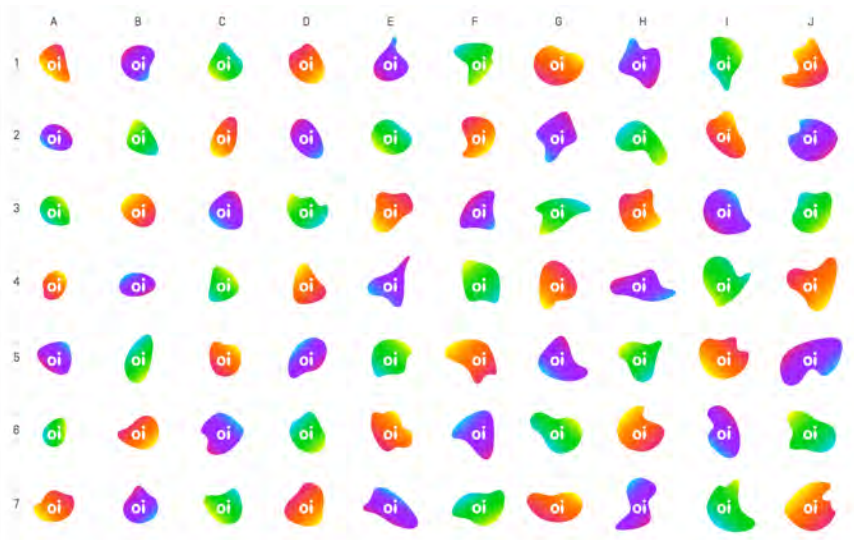

Fontes: (a) Wolf Olins e GAD’Design (2002, p. 9); (b) FutureBrand (2016, p. 18). Último acesso em 26/10/2017. 


\section{O signo-cor como designador-de-atributo}

Além de caracterizarem uma marca, as cores também operam como um signo identificador-de-atributos não especificadores de marca. A caracterização pode ser apenas estética-visual (a cor em si, que colore um material), ou designadora de sabor, aroma, ingrediente, função, país de origem, público-alvo, etc. Na medida em que as marcas expressam atributos similares, repetidamente, por meio das mesmas cores, constrói-se uma rede associativa na memória do consumidor, estabelecendo normas categorizadoras (Labrecque \& Milne, 2013). Ao caracterizar uma marca como pertencente a um ou outro grupo, a cor está designando o atributo "categoria"; ao caracterizar os ingredientes de cada variedade ofertada, a cor está designando o atributo "sabor", e assim por diante. Quando a cor caracteriza um atributo de maneira exclusiva ou fora de regras da categoria, essa cor passa a operar como designadora-demarca (ver subseção acima).

As normas pelas quais a cor opera como um designador-de-atributo podem ser locais ou globais. Por exemplo, na Europa, as marcas de chocolates, bolos, guloseimas, etc. utilizam o verde para designar "avelã", um ingrediente comum na região (Figura 2.6). Esse código cromático não é, ao menos por enquanto, compartilhado pelas marcas de alimentos no Brasil, onde o ingrediente é mais raro: por experiência própria, esta autora (nascida e criada no país) pensou que os europeus adoravam chocolate-com-menta, quando visitou pela primeira vez o continente, duas décadas atrás.

Figura 2.6: O verde como designador de avelã na categoria chocolate, na Europa.

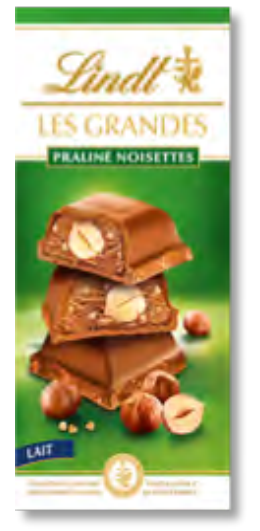

(a)

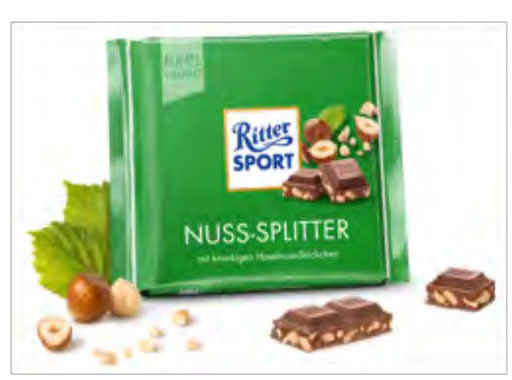

(c)

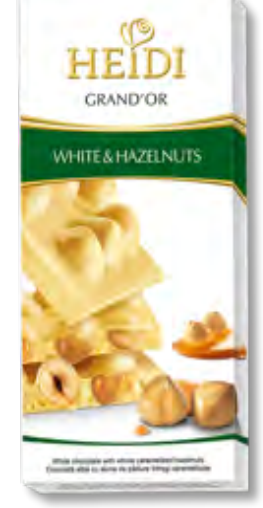

(d)

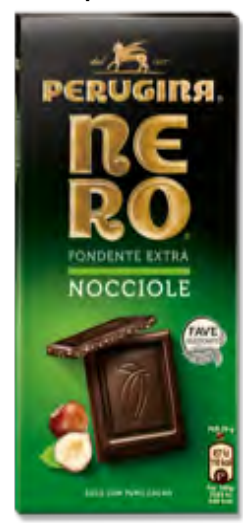

Fontes: Sites das marcas (a) Lindt (2015), (b) Ritter Sport (2018), (c) Heidi (2018), (d) Perugina (2016).

Como exemplos de cores caracterizando atributos em escopo global, tem-se os sacos brancos para farinha (Garber Jr. \& Hyatt, 2003); o cor-de-rosa designando um público feminino (Koller, 2008; Vaisman, 2016); e cigarros em embalagens "mais brancas" ou em combinações 
cromáticas mais claras do que as cores das embalagens normais, indicando versões "suaves" (mild, light ou ultra-light) (Bansal-Travers, O’Connor, Fix, \& Cummings, 2011).

Quando a marca se caracteriza cromaticamente em conformidade com as convenções da categoria, geralmente definidas pelos líderes do mercado, ela captura significações já estabelecidas, evocando familiaridade, mas diminuindo sua distinção. Ao contrário, quando não segue normas cromáticas, pode confundir o consumidor, mas provoca curiosidade, além da diferenciação visual em relação aos concorrentes (Labrecque \& Milne, 2013).

\title{
A interação entre as cores, designando a marca e seu atributos
}

A cor sempre designa uma marca ao caracterizar cromaticamente as superfícies (materializações) onde é aplicada. Os demais modos de significação, discutidos nas seções a seguir, pressupõem a cor operando no modo atentivo e designativo: possibilita a percepção visual de um logotipo, uma embalagem, uma propaganda, etc. e, junto com outros elementos visuais (formas e grafismos, tipografia, fotografia, etc.), evoca a caracterização da marca específica, junto aos públicos.

É importante ressaltar que, designando a marca e seus atributos, as cores não operam isoladamente, mas interagem entre si incessantemente, tanto no aspecto perceptivo (ver modo atentivo, acima), quanto no simbólico. Isso fornece aos designers e comunicadores visuais, a vantagem de infinitas possibilidades expressivas e o risco de efeitos interpretantes novos ou inesperados, mesmo quando a manipulação combinatória envolve cores que já participam da paleta cromática da marca.

\begin{abstract}
Uma cor nunca fica sozinha; Só deriva seu significado, ela apenas "funciona" completamente na perspectiva social, artística ou simbólica, na medida em que é combinada em contraste com uma ou várias cores. Por isso, é impossível considerá-la isoladamente. Para discutir o vermelho, também devemos discutir o azul, amarelo, verde e, especialmente, o branco e o preto. ${ }^{18}$ (Pastoureau, 2017, p. 8)
\end{abstract}

Um exemplo é a interação simbólica das cores da Coca-Cola. A cor vermelha, original da marca, é usada em combinação com outras cores, que até 2016 designavam quatro submarcas

\footnotetext{
18 "A color never stands alone; it only derives its meaning, it only fully "functions" from the social, artistic, or symbolic perspective, insofar as it is combine or contrasted with one or many colors. Hence, it is impossible to consider it in isolation. To discuss red, we must also discuss blue, yellow, green, and especially white and black".
} 
do portfólio (Figura 2.7a): prata caracterizando a Coca-Coca Diet (ainda comercializada nos E.U.A.), preto para a Coca-Cola Zero (a partir de 2005), e verde para a Coca-Cola Life (2013). Recentemente, a Coca-Cola reestruturou a arquitetura do portfólio para uma estratégia de marca única, e transformou as submarcas em simples variações de adoçante, com o apoio das mesmas cores designadoras (The Coca-Cola Company, 2016). Para reforçar a significação de marca única, o vermelho foi aplicado mais destacadamente nas embalagens, dominando as interações cromáticas sígnicas nas quatro versões (Figura 2.7b).

Figura 2.7: Interação cromática designando (a) o portfólio de quatro submarcas, até 2016; e

(a)

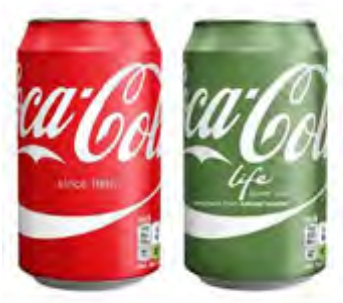

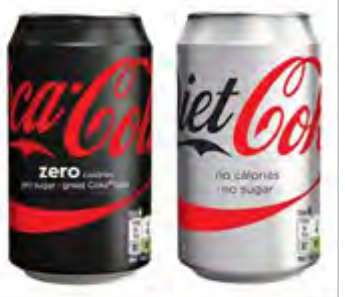

(b)

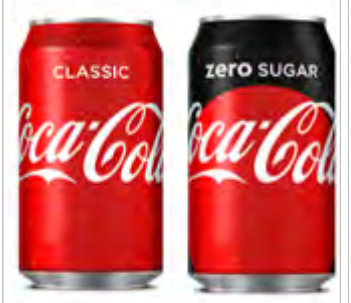

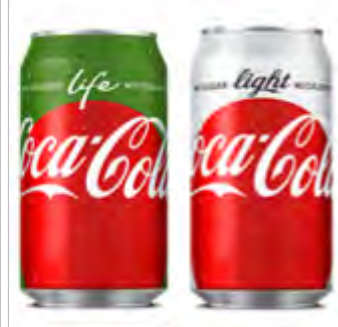

Fontes: (a) (Miller, 2015);(b) (Cola-Cola Company, 2016). Último acesso em 14/12/2017.

Ao decidir manter o código cromático organizador, a Coca-Cola evitou os efeitos negativos que provocou no Natal de 2011, quando alterou temporariamente a aplicação do vermelho designador da versão normal do refrigerante. Na campanha Arctic Home, para arrecadação de fundos para a proteção dos ursos polares (mascotes desde 1922), a marca os desenhou em duas combinações de cores: fundo branco/ursos em prata e fundo vermelho/ursos brancos (Figura 2.8).

Figura 2.8:(a) Latas das versões Clássica, Diet e Zero; (b) Latas Artic Home, versão Clássica.

(a)

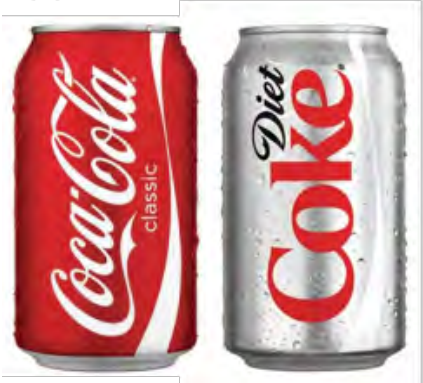

(b)

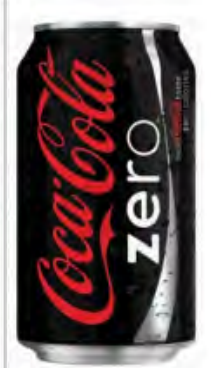

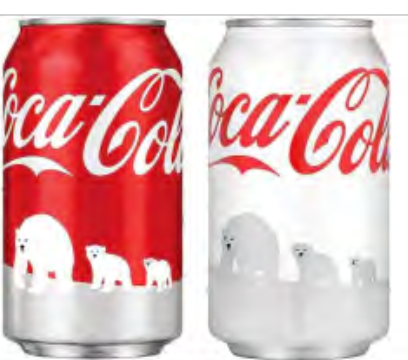

Fontes: (a) Blog Brand New (Selikoff, 2007) e (b)Site da Coca-Cola (2011). Último acesso em 25/10/2017.

A opção prata/branca confundiu os consumidores, que a identificaram como a versão diet. Diabéticos e pessoas em regime de restrição calórica consumiram o açúcar que não deviam, enquanto compradores usuais da versão normal reclamaram sobre o sabor do 
refrigerante, que estaria diferente (Goddard, 2011, The Telegraph). A empresa explicou que as alterações ocorreram apenas nas cores e não na composição do produto (The Coca-Cola Company, 2011), e descontinuou a lata promocional prateada.

Uma vez que cor sempre designa a marca que a aplica, o modo designativo é altamente relacionado e implicado nos demais modos de significação. Assim, qualquer mudança cromática de uma marca (a ser discutida no modo transformativo de significação) tem o poder sígnico de alterar os efeitos interpretantes junto aos públicos, e deve ser amplamente analisada e testada antes de seu lançamento no mercado.

\section{QUESTÃO 3 DA TESE:}

\subsection{A cor induz apreciações em relação a uma marca?}

Na teoria de Morris (1946), um signo que significa um status preferencial (valuata) sobre algo, é um signo apreciador (appraisor), como os termos "bom", "ruim", "bonito" e "feio". Signos designadores, além de operarem no modo designativo, também podem apresentar um componente apreciativo: as designações "honesto" e "ladrão" também significam uma apreciação, positiva e negativa, respectivamente, na maioria dos contextos (Morris, 1946, p. 80).

Da mesma forma, os nomes das cores têm um componente de apreciação, apesar de serem signos predominantemente designadores: na frase "a banana está verde", o designador "verde" significa uma característica da fruta, mas também a provoca uma disposição negativa (modo apreciativo de significação): ela não está boa para ser consumida. Nesse contexto, fica evidente a interdependência do modo apreciativo e do modo prescritivo: o desapreciar evoca a ação de não-comer a banana.

Também na dimensão visual, e considerando as três dimensões cromáticas (matiz, brilho e saturação), as cores dispõem o intérprete a um favorecimento ou desfavorecimento: elas provocam diferentes respostas afetivas, positivas e negativas, nos indivíduos (e.g. Moller, Elliot, \& Maier, 2009; Ou, Luo, Woodcock, \& Wright, 2004a, 2004b) os quais, por isso, gostam mais (ou menos) de uma cor (ou de uma combinação de cores) (e.g. Crozier, 1999; Ou, Luo, Woodcock, \& Wright, 2004c; Smets, 1982) e apreciam mais (ou menos) o objeto colorido. Essas respostas, positivas ou negativas, comumente ocorrem sem o discernimento do perceptor do estímulo visual cromático (Elliot \& Maier, 2012), o intérprete. 
O contexto é tão determinante nos efeitos das cores que pode inverter a valência das emoções e julgamentos que provoca: mulheres vestindo camisetas vermelhas foram avaliadas, por homens, como mais sexualmente receptivas, mais atraentes e desejadas do que mulheres em camisetas brancas (Pazda, Elliot, \& Greitemeyer, 2012). Porém, em situação competitiva, jogadores(as) em uniformes vermelhos (vs. uniformes azuis) se sentem e são percebidos(as) como mais dominantes e mais ameaçadores(as) (Feltman \& Elliot, 2011).

Os moderadores da apreciação das cores são, conhecidamente, a idade, gênero, país de residência, religião e base cultural dos indivíduos (Child, Hansen, \& Hornbeck, 1968; Hurlbert \& Ling, 2007; Saito, 1996; Valdez \& Mehrabian, 1994). Os aspectos subjetivos influenciam fortemente as respostas às cores, como o gosto pessoal, a preferência emocional (Terwogt \& Hoeksma, 1995), a personalidade (Lüscher \& Scott, 1971) e as experiências individuais prévias com as cores (Kaya \& Epps, 2004).

Cada região tem uma visão diferente das cores. Por exemplo, pela
minha experiência em trabalhar para o Brasil, as cores mais fortes
são mais preferidas do que as mais fracas, devido à personalidade,
ao clima, etc. E também olhamos em um outro nível. Vamos ver
como as cores devem ser aplicadas para a moda homem, moda para
mulher, moda infantil. (Depoimento de especialista - WGSN)

Da mesma forma, as exterioridades interferem no modo dos indivíduos considerarem a cor, por exemplo: o tipo de objeto colorido e as condições de visualização. Preferências por amostras (chips coloridos) são distintas das preferências por cores aplicadas em objetos reais (Taft, 1997); Indivíduos apreciam mais as cores advindas de um objeto emissor de luz (tela de celular, monitor de TV) em comparação às mesmas cores visualizadas em uma superfície colorida e iluminada por luz ambiente (Tangkijviwat, Rattanakasamsuk, \& Shinoda, 2010).

Assim, ajustando o modo apreciativo de Morris ao âmbito da cor e marca, tem-se a terceira proposição da tese:

\section{Proposição 3: a cor significa a marca no modo apreciativo (appraisive mode)}

Uma cor (ou uma combinação de cores), aplicada em elementos e materiais marcários, significa uma marca no modo apreciativo quando dispõe seus públicos a favorecer ou desfavorecer essa marca, induzindo-os atitudes positivas ou negativas em relação a ela. 
Inúmeros estudos acadêmicos discutem a associação entre as cores e a apreciação de produtos e marcas, sugerindo que certas cores são mais (ou menos) "apropriadas" para provocar reações positivas (ou negativas) a depender do ponto-de-contato em questão, da categoria de produto, do tipo de marca, etc. Ao mesmo tempo, os diferentes resultados obtidos nas múltiplas situações experimentais, reforçam a ideia de que as cores evocam apreciações de maneira complexa e ambígua (Crozier, 1999), que devem ser estudadas caso a caso. Assim, esta tese não ratifica nem refuta o tipo ou valência das emoções e atitudes que cada cor especificamente provocou nos experimentos revisados a seguir. $\mathrm{O}$ intuito aqui é expor as evidências científicas sobre a capacidade sígnica das cores em induzir apreciações, para marcas.

Por exemplo, em estudo sobre logotipos e embalagens, as cores promoveram a personalidade, familiaridade e preferência de marca e produtos: logos em branco ou em rosa foram avaliados como sinceros; logos em vermelho como excitantes; em azul como competentes; em preto, rosa ou roxo como sofisticados; em marrom como robustos e resistentes (Labrecque \& Milne, 2012). Ao testar variações de saturação e de brilho, o mesmo trabalho verificou que, quanto mais saturada a cor, mais o logotipo é julgado como excitante, e quanto mais clara a cor, menos resistente e robusto o logo é percebido. Em relação a embalagens, o estudo confirmou os mesmos efeitos verificados em logotipos e que a personalidade percebida influencia a expectativa de compra.

Em outro trabalho, testando apenas duas cores, o azul foi considerado mais apropriado para logotipos de marcas que oferecem produtos "funcionais", enquanto o vermelho foi melhor avaliado para logos de produtos “sensoriais-sociais" (Bottomley \& Doyle, 2006).

Em pesquisa realizada há 15 anos, quando 15-20 segundos ainda era um tempo de espera aceitável para carregar os dados de um website, as páginas da internet com a cor azul (vs. amarela ou vermelha) foram melhor avaliadas e mais recomendadas, por serem consideradas mais rápidas para baixar - a percepção positiva de relaxamento agiu como mediadora da relação entre cor e a rapidez do download (Gorn, Chattopadhyay, Sengupta, \& Tripathi, 2004). Em simulação de ambientes de compra (uma loja de televisão e uma loja de móveis), os indivíduos preferiram a ambientação em azul, mais relaxante e agradável, do que em vermelho, mais tensa e desagradável (Bellizzi \& Hite, 1992).

Inúmeros experimentos testaram as cores na publicidade, principalmente propaganda impressa. Em um deles, peças usando cores mais saturadas (vs. menos saturadas) ou mais claras (vs. cores mais escuras), foram avaliadas como mais excitantes e relaxantes, respectivamente, e 
ambos os efeitos provocaram atitudes positivas em relação à peça publicitária. No caso das propagandas com cores claras, a avaliação positiva foi transferida para a marca anunciante (Gorn et al., 1997). Em estudo mais recente, indivíduos foram expostos a propagandas impressas de uma marca corporativa, logo após receberem informações negativas sobre esse anunciante. A propaganda com a cor azul provocou reações mais condescendentes dos leitores, quando a peça era um pedido de reparação dos erros (vs. negação das falhas cometidas). A propaganda com o vermelho provocou avaliações mais negativas sobre a empresa, independentemente de o anúncio expor soluções para os problemas ou negá-los (Puzakova, Kwak, Ramanathan, \& Rocereto, 2016).

Em outro estudo, testando a cor de fundo, a cor vermelha motivou os indivíduos a um afastamento ou repúdio, aumentando a atenção e a memória em campanhas de prevenção. Por sua vez, a cor azul gerou uma avaliação favorável do anunciante, pela ativação de sentimentos de proximidade, em campanhas que destacaram benefícios positivos (Meht \& Zhu, 2009).

A cor em produtos alimentícios interferindo na avaliação dos consumidores é uma frente de investigação complexa, pois envolve aspectos sinestésicos: ao alterar a percepção de identificação e intensidade dos sabores e aromas, a cor influencia na aceitação, escolha e preferência por comestíveis e bebestíveis (Clydesdale, 1993; Walsh, Toma, Tuveson, \& Sondhi, 1990). Embalagens de comidas e bebidas também impactam a preferência por marcas e produtos, ao influenciarem as percepções do que é mais ou menos saudável/nutritivo, e do que é mais ou menos apetitoso/saboroso (Mai, Symmank, \& Seeberg-Elverfeldt, 2016; J. A. Mead \& Richerson, 2018; Sundar, Gonsales, \& Sung-Hee, 2017).

A capacidade do signo-cor em evocar emoções e atitudes positivas para as marcas é amplamente reconhecida pelos especialistas, que a exploram para o benefício das marcas:

Tem que escolher uma [cor] que evoque a sensibilidade, a mesma emoção da sua marca, o que ela é: cores fortes ou suaves, ou um simples preto e branco? Tudo se resume ao que a marca realmente é. (Depoimento de especialista - Louboutin)

Seja qual for a cor do governo, geralmente, a bandeira nacional tem algum tipo de relação com a construção da marca. Tem muita marca laranja na Holanda, e você não vê muito laranja no mundo. Então, de alguma forma, o significado associado ao laranja, o que a cor significa no país, tem um aspecto de aprendizagem herdado. (Depoimento de especialista - FutureBrand) 


\section{Amor e ódio: a intensidade emocional das cores}

As emoções e atitudes mais extremadas parecem ser provocadas pelas cores de marcas de times, grupos, nacionalidades, mediadas pelo sentimento de pertencimento evocado nos integrantes de agremiações esportivas, políticas, culturais, nacionais: torcedores do time paulistano Palmeiras amam o seu "verdão!"; brasileiros contra o Partido dos Trabalhadores gritam "nossa bandeira jamais será vermelha!"; integrantes do Boi Caprichoso amam o azul e odeiam o vermelho... os do Boi Garantido, exatamente o contrário.

Quando eu fazia projetos em diferentes países, encontrava ... 85\% das empresas americanas usando vermelho ou azul em seus logotipos, por causa da bandeira americana. Se você vai para o Brasil, verá muito verde, amarelo e azul nas empresas, faz parte da identidade brasileira, está na bandeira. Você vai para a Rússia, vai ser vermelho, na França e na Inglaterra vai ser vermelho e azul. As identidades nacionais são capturadas nas cores. As bandeiras islâmicas têm verde. Há uma tremenda variação cultural, dependendo de onde você é, a história, herança, religião e cultura. (Depoimento de especialista - Bell Brand Advisors)

Enquanto a literatura acadêmica evidencia a valência negativa ou positiva dos efeitos cromáticos, a experiência prática dos especialistas revela o quão intensas podem ser essas apreciações que as cores provocam:

A cor é uma das primeiras coisas que os consumidores notam, antes mesmo de olhar para o produto. Eu faço focus groups, com frequência. Quando eu vou conversar com pessoas de uma universidade... eu tento levar todos os produtos na mesma cor do time da escola. Se eu levar para uma universidade vermelha, um par de sapatos em vermelho e outros pares em cores diferentes, os participantes gravitarão automaticamente ao redor do vermelho, não importa se eles gostam ou não do produto. O produto existe em 13 cores..., mas é essa que eles discutem. O contrário, a mesma coisa: se eu levar uma cor que seja a do time rival, eles automaticamente odiarão esse sapato. Não importa... eles não percebem que é o mesmo modelo. Eles pegam o tênis que mais gostam e o que mais odeiam. Cor é o motivo número UM pelo qual as pessoas são atraídas por um produto. (Depoimento de especialista - New Balance)

Existe definitivamente uma conexão emocional [entre a cor da marca e seu público] e não é fácil de se criar. Pode demorar algum tempo para se instalar na mente da pessoa..., mas quando essa associação se faz, é muito impactante. (Depoimento de especialista - Louboutin) 
No esporte, a área que eu conheço melhor, existe uma conexão emocional entre o time e os fãs... e a cor é parte disso, verde e amarelo são as cores da minha escola, do meu time! (Depoimento de especialista - University of Oregon)

É necessário explicitar a diferença entre a dimensão estética e a dimensão simbólica das cores, frequentemente embaraçadas nas reações emocionais que suscitam. Embora se interpenetrem e se influenciem mutuamente, são conceitualmente distintas e podem exercer influências opostas na apreciação de uma marca - alguém pode gostar de uma cor, mas não gostar do que ela significa em determinados contextos (Creusen \& Schoormans, 2005). Assim, um torcedor palmeirense pode amar o verde pelo que ele significa, e passar a preferir esteticamente produtos e marcas que utilizam o verde. Ou, uma eleitora brasileira de inclinação à direita pode odiar o vermelho pelo que ele significa politicamente, e ainda assim amar a cor, especialmente em seu vestido de festa preferido.

O prazer/desprazer advindo das experiências sensoriais estéticas que as cores proporcionam são relevantes para as marcas (Brakus, Schmitt, \& Zarantonello, 2009; Schmitt \& Simonson, 2002) e, ao longo do tempo, carregam a cor de valuata positiva/negativa, em um âmbito pessoal ou coletivo. Assim, com a repetição, as respostas emocionais e atitudinais provocadas por motivações estéticas são incorporadas à carga sígnica (interpretante) da cor, que irá dispor os intérpretes-consumidores a apreciarem positiva/negativamente as marcas que a utilizam. Um exemplo é a marca americana Purple (roxo, em inglês) de colchões e acessórios para dormir. Por ser ainda rara em produtos e marcas, os fãs (carentes) da cor roxa tornam-se adoradores e consumidores da marca Purple:

Temos muito tráfego em mídia social.... De forma consistente, em quase todas as postagens, há alguém que diz "Eu adoro a cor roxa", ou "Por que você não tem [o produto] em roxo?" Estamos construindo uma empresa de colchões, o objetivo de longo prazo é ser uma empresa de conforto. Não temos lençóis roxos, por exemplo. Nós temos lençol bege, cinza, branco, mas não temos em roxo. $E$ isso deixa as pessoas muito bravas. (Depoimento de especialista - Purple)

\section{Positivo ou negativo? Valências e ambiguidades culturalmente construídas}

Signos apreciadores significam algo, para alguém, ao longo um eixo positivo-negativo contínuo, ou seja, significam valuata com gradações intermediárias (Morris, 1946, p. 82). 
Aplicando o conceito de Morris, o signo-cor opera como um apreciador para as marcas em intensidades variadas, cuja valência (do muito positivo ao muito negativo) decorre da interação entre as predisposições fisiobiológicas (imutáveis) e as práticas socioculturais (suscetíveis a mudanças), as duas fontes dos significados cromáticos já discutidas.

A tese aqui propõe que a associação já estabelecida entre uma cor e valores e práticas culturais consideradas positivas ou negativas (considerando também questões fisiobiológicas), pode provocar respostas positivas ou negativas em relação às marcas designadas por essa cor. $\mathrm{O}$ enfoque da Antropologia ampara a proposição: se o sistema de publicidade/moda transfere significados, positivos e negativos, do mundo culturalmente constituído para as marcas (McCracken, 1986, 1993), a cor é um dos vetores de transferência, quando aplicada nos elementos de identidade e materiais de comunicação de marca.

Por exemplo, a valência positiva da cor vermelha: ela é considerada uma cor de sorte em países de cultura chinesa e usada em ocasiões especiais, como em vestidos de noiva (Kramer \& Block, 2008). Um estudo na Tailândia confirmou a influência positiva da cor, em produtos de cozinha, no qual os participantes esperavam que a panela de arroz vermelha (vs. verde, considerada cor neutra na cultura chinesa) funcionaria melhor e, por isso, intencionavam comprar mais o produto nessa cor por "dar sorte" a quem o possuir (Block \& Kramer, 2009). Assim, marcas tailandesas de certas categorias podem ser favorecidas ao usarem a cor vermelha.

Por sua vez, na sociedade ocidental a cor verde é associada à natureza (Heller, 2004), à vegetação (Pastoureau, 2014) e aos aspectos positivos do conceito de naturalidade, como "aceitável", "benigno", "seguro" e "saudável" (Nuffield Council on Bioethics, 2015), potencializados com as preocupações atuais sobre o meio-ambiente. Corroborando com a ideia da tese, uma pesquisa realizada no Estados Unidos testou logotipos de uma marca hipotética de supermercado com versões em vermelho, laranja, amarelo, verde, azul e preto. Os logotipos em azul e verde provocaram respostas mais positivas em relação às práticas ambientais das empresas fictícias que, por conseguinte, foram consideradas mais éticas pelos participantes (Sundar \& Kellaris, 2016).

As preferências pessoais pelas cores podem mudar ao longo da vida (Strauss, Schloss, \& Palmer, 2013) por fatores intrínsecos (memórias, sentimentos, experiências anteriores) e extrínsecos (valores socioculturais em contínua mudança). O sistema da moda, definidor e acelerador da sazonalidade do que é cromaticamente valorizado em um dado momento, instaura tendências, normas, hábitos, preferências, influenciando a percepção de qualidade, inovação, 
atualidade. Por exemplo, na década de 1970, o laranja era uma cor moderna para roupas, mobiliários e acessórios; nos anos 1980, era percebida como feia e ultrapassada; e nos anos 1990, voltou a ser usada em produtos e roupa (Creusen \& Schoormans, 2005).

A cor é um capítulo à parte da marca, porque ela é a expressão do tempo... comportamentos, gostos, atitudes e valores das pessoas daquele momento.... Os refrigeradores, fogões, máquinas de lavar roupa, tinham cores muito criativas. Nos anos 1950-60, você encontrava o branco, mas também o amarelo, azul calcinha, rosabebê. Essas cores pasteis começaram a dar espaço nos anos 1970 para o verde musgo, o vermelho sangue, o café-com-leite.

$\ldots$

E evoluindo... nos anos 1980 as pessoas queriam mais branco, não sei se cansaram de cor demais, ou quiseram deixar a cozinha mais limpa... o conceito clean veio muito forte para a cozinha....

Junto com o design clean, veio o inox. Era premium... tinha essa imagem de assepsia, de limpeza, sofisticação, um negócio europeu. Só que era muito caro! ...

Nos anos 2000 começaram a entrar as cores premium e as cores pretas. Tínhamos diversos produtos pretos, linha preta... ainda mais caros que o inox. (Depoimento de especialista - Whirlpool)

Recentemente, consultores de tendências de cores presenciaram a mutabilidade sígnica cromática na China, com o verde desaturado (verde-oliva ou verde-exército), e no Ocidente, com o rosa-claro desaturado (agora denominado "rosa millennial"):

Nós temos uma colega em Shangai trabalhando em tendências de cores folclóricas.... Ela me falou há alguns anos atrás: "não, nunca usaremos o verde-exército, há muita conexão com o passado". Agora, ela está dizendo "todos os caras legais em Shangai querem usar o verde-militar, está na moda". Dois anos atrás, ela nunca diria isso. O país está mudando rapidamente. $\ldots$

A razão pela qual o millennial pink foi tão amado é por ser uma grande história. O rosa é uma cor para meninas ou mulheres muito femininas. E agora, para os millennials, homem ou mulher, é uma escolha moderna para todos usarem em vários sentidos. É uma história louca, uma atitude-neutra em termos de gênero, que os abaixo de 30 anos estão abraçando.... É um tema quente que todos querem falar, ... mostra que a cor é algo realmente importante para a sociedade. A escolha da cor diz muito, e está dizendo que as pessoas mudaram sua atitude sobre como homens e mulheres são identificados. (Depoimento de especialista - WGSN) 
Além de provocar apreciações em diferentes gradações, uma mesma cor possui associações de valências opostas. Novamente, o caso do vermelho: a carga negativa de ser a cor do perigo, do sangue, da proibição, mas também a positividade da cor do amor, da paixão, do erotismo, da vida, da revolução (Guimarães, 2000, pp. 113-121). Graças a essa natureza polissêmica e dinâmica, o signo-cor evoca sentimentos e julgamentos dos mais variados, mutáveis ao longo do tempo, do espaço e do contexto competitivo. É na pragmática do seu uso, interagindo com outras cores e outros signos visuais e verbais, que a cor se revela boa ou má, adequada ou não, em seus papéis estratégicos para as marcas.

QUESTÃO 4 DA TESE:

\subsection{A cor provoca uma ação em relação a uma marca?}

De acordo com a classificação de Morris, signos prescritores são aqueles que induzem a algum comportamento requerido (obligata), respostas "herdadas" (predisposições biológicas, reações fisiológicas) ou aprendidas, e que são executadas a fim de satisfazer as necessidades motivadoras (Morris, 1946, p. 83). Na linguagem verbal, Morris exemplifica o modo prescritivo de significação com a frase "venha aqui!", que significa, para um intérprete, a obrigação de uma performance: aproximar-se do produtor do signo.

Signos prescritores normalmente requerem uma designação (por um signo operando no modo designativo) que especifique a ação demandada, e frequentemente demandam uma apreciação (modo apreciativo) que favoreça o cumprimento da prescrição. Esse é o caso da frase, "você deveria fazer isso!", onde o verbo "dever" prescreve e ao mesmo tempo aprecia uma ação (Morris, 1946, p. 85).

Assim, adaptando o modo prescritivo de Morris para as cores e marcas, tem-se a quarta proposição da tese:

\section{Proposição 4: a cor significa a marca no modo prescritivo (prescriptive mode)}

Uma cor (ou uma combinação de cores), aplicada em elementos e materiais marcários, significa uma marca no modo prescritivo quando dispõe os públicos para agir determinadamente em relação a essa marca. 
Para dizer que o signo-cor, operando no modo prescritivo, dispõe o consumidor a responder com uma ação (ou com a intenção de agir, conação), faz-se necessário esclarecer a acepção do verbo "prescrever" ${ }^{19}:$ 1) ordenar antecipada e explicitamente; 2) dar ordem ou determinação para que se faça algo; 3) aconselhar uma norma de comportamento, uma prática, normatizar; 4) fixar (data, hora, prazo); determinar, ...; 5) recomendar; receitar.

Obviamente, a marca não pode obrigar os indivíduos a "fazerem algo" na literalidade do termo, nem mesmo na linguagem verbal, quando anuncia: "Compre 2 e leve 3!"; "Não perca!”. Aqui, a proposição da cor como prescritora indica que ela influencia a compra (para colecionar, para presentear), o uso e a exibição (para se exibir nas redes sociais), o descarte (uma cor "fora-de-moda") e outras condutas cotidianas ou ritualísticas, positivas ou negativas, em relação às marcas. Essas respostas comportamentais às cores, conscientes ou não, são explicadas por Flusser (2007) como uma programação, uma elaboração do mundo imagético pós-moderno sobre os humanos:

Nossas meias e pijamas, conservas e garrafas, exposições e publicidade, livros e mapas, bebidas e ice-creams, filmes e televisão, tudo encontra-se em tecnicólor. Evidentemente não se trata de um mero fenômeno estético, de um novo "estilo artístico". Essa explosão de cores significa algo. O sinal vermelho quer dizer "stop!", e o verde berrante das ervilhas significa 'compre-me!'. Somos envolvidos por cores dotadas de significados; somos programados por cores, que são um aspecto do mundo codificado em que vivemos. (Flusser, 2007, p. 128)

As disposições suscitadas pela cor no modo prescritivo são distintas das respostas apreciativas e designativas, embora possam decorrer dessas. Crowley (1993), em estudo quantitativo sobre ambientação de loja física, distinguiu "ao menos" duas dimensões das cores, uma provocando avaliações dos consumidores, a outra provocando a "ativação" dos indivíduos em ambiente de varejo, tornando-os mais propensos a comprarem por impulso. Sob o ponto de vista semiótico aqui proposto, o trabalho de Crowley diferenciou experimentalmente o modo apreciativo de significação (cor provocando o indivíduo a gostar mais ou menos de algo) do modo prescritivo (cor evocando uma ação de compra).

\footnotetext{
${ }^{19}$ Segundo Dicionário Português Oxford University Press @ $@ 2012$ Editora Objetiva. Versão eletrônica para Macintosh. As duas últimas acepções do verbo prescrever não cabem no contexto: "6) ficar sem efeito por ter decorrido certo prazo legal; caducar; 7) cair em desuso".
} 
Apoiando a ideia de Morris sobre a interdependência dos modos de significação (1946, p. 87), as pesquisas demostraram que a cor induz os consumidores a ações (signo-cor no modo prescritivo), sendo essas decorrentes da cor tornar os ponto-de-contato acessíveis à percepção (modo atentivo), caracterizar a marca e suas propriedades (modo designativo) e causar uma apreciação favorável à marca (modo apreciativo).

\begin{abstract}
Aprendemos que qualquer coisa que produzimos, precisamos ter uma opção roxa, seja lá o que for. Há tantos fãs de roxo que nos seguem, que procuram conteúdo [nas redes sociais].... Nem todos os americanos compram de nós, mas todos que adoram o roxo compram de nós. (Depoimento de especialista - Purple)
\end{abstract}

Estudos recentes são especialmente interessados em investigar a cor no $e$-commerce, no m-commerce (comércio mobile, por telefone celular) e nas experiências digitais em geral. Por exemplo, em experimento sobre compra on-line, o site cuja cor de fundo era azul (vs. amarela) provocou o comprador a ficar mais tempo navegando no site e a visitar mais páginas do site. Além disso, o site azul induziu a uma maior intenção de compra e de revisitação do site. As respostas afetivas de diversão e concentração evocadas nos indivíduos (cor no modo apreciativo) mediaram os efeitos sobre o comportamento (cor no modo prescritivo) em relação à loja online (Aboubaker Ettis, 2017).

Estudo anteriores, discutidos aqui previamente, também evidenciam a cor dispondo os indivíduos à ação. Bellizzi e Hite (1992) testaram ambientações de loja de televisão e de móveis em azul (vs. vermelho), que foram avaliadas positivamente pelos participantes, induzindo-os a mais compras simuladas e menos adiamentos de compra, além da maior intenção de comprar e de procurar produtos. Similarmente, as reações positivas dos tailandeses à cor vermelha, provocaram uma maior intenção de compra e uma propensão a pagar mais caro pela panela de arroz vermelha em comparação à panela verde (Block \& Kramer, 2009).

Assim, as preferências cromáticas mostram-se um grande mediador/provocador das ações de compra. As marcas, cientes disso, repensam sua linha de produção e suas campanhas promocionais:

Existem cores que são icônicas em relação ao tempo... se você pensa nos anos 50, eram as cores pastel, com os rosas, os amarelos, verde-cor-de-menta e o azuis-bebê. Nos anos 70, tínhamos verdes e laranjas... tudo bem, é para isso que as tendências servem. Você sempre te que certificar-se que está desenvolvendo uma coleção com cores básicas, mas também com 
cores da tendência... porque há pessoas que vão querer estar na moda, que querem se expressar dessa maneira.

Cada pessoa no mundo tem um gosto pessoal quando se trata de cores.... As cores são muito pessoais e também culturais. A cor que vende na América do Sul será diferente da que vende na América do Norte, na Europa... na China. E mesmo dentro da Europa, as cores vão vender de forma diferente na Alemanha, na Espanha, na França... na Itália. Mesmo nos EUA, as cores que vão vender mais em Miami serão muito diferentes das de NYC, Detroit, ou Los Angeles.... Temos cores principais que formam nossa paleta global, mas também temos cores feitas para cada região. (Depoimento de especialista - Ford Motor Company)

\section{O ritual e o cotidiano da cor na prescrição do consumo marcário}

Embora "comprar" seja a ação essencial a ser provocada - antes de tudo, por uma questão de sobrevivência financeira -, ela não é a única resposta comportamental que a marca pode ou espera incitar em seus públicos. Em uma escala de engajamento, o comprar e o usar estariam em um nível mínimo, enquanto falar sobre a marca (boca-a-boca ao vivo, por WhatsApp, ou no Reclame Aqui ${ }^{20}$ ), postar sobre ela (Twitter, Facebook, etc.), visitar o site, ler e responder e-mails e postagens, são ações de alto grau de envolvimento com a marca (K. L. Keller, 2016).

Certas ações dos indivíduos-consumidores, em um olhar antropológico, são encaradas como rituais de consumo: de troca, posse, arrumação e despojamento (McCracken, 1986, 1993). Quando mediadas pelo digital, essas ações são consideradas novos comportamentos ritualísticos que exprimem a atual sociedade conectada em rede: uma nova estrutura dominante, resultante da crise econômica, da revolução da tecnologia da informação e do apogeu de movimentos socioculturais (Castells, 1999, p. 412).

As ações de exibir-se ou reclamar publicamente sobre marcas, via online, atuam como dispositivos midiáticos, articuladores de práticas simbólicas e criadores de vínculos de sentido entre indivíduos e marcas, em variadas gradações de intensidade, sequência e repetição (Trindade \& Perez, 2014). Por exemplo, a utilização de hashtags como prática de expressão de

\footnotetext{
${ }^{20}$ Site brasileiro de reclamações sobre produtos e serviços: www.reclameaqui.com.br.
} 
emoções e de seleção, curadoria e interligação de conteúdo, configuram um ritual novo, o de marcação do consumo midiatizado (L. S. Souza, 2017, p. 292).

É importante salientar que a linha diferenciadora do que seja um comportamento online ou off-line torna-se a cada ano mais indefinida. Em 2016, 56\% das compras efetuadas no varejo físico, nos Estados Unidos, foram influenciadas por algum comportamento online do consumidor - buscar as opções de produtos e marcas, pesquisar preços, comparar as características das ofertas, ler e compartilhar as experiências prévias com outros consumidores, etc. Em 2013, essa influência era de apenas 13\% (Simpson, Ohri, \& Lobaugh, 2016).

Assim, ao significar a marca no modo prescritivo, a cor dispõe seus públicos a ações e rituais físicos-presenciais ou digitais, provocados por manifestações marcárias "reais" ou "virtuais", indiscriminadamente e de maneira entrelaçada.

Por exemplo, o comportamento das autodenominadas "viciadas" em esmaltes: buscam informações e debatem sobre cores e estilos nas redes sociais das marcas e em blogs de influenciadoras; escolhem e compram as cores via online ou off-line; organizam seus vidrinhos na sua casa, em dégradé e/ou na ordem do espectro de luz; exibem suas coleções (competição por quem tem mais cores ou quem melhor arruma); pintam suas unhas de forma inusitada e trocam de cor semanalmente (e postam novamente); elogiam/criticam as colegas/competidoras e se auto elogiam, presencialmente e online; usam uma única vez cada esmalte (não repetem cor) e não descartam os vidrinhos, a não ser quando ganham um exatamente igual (cor e marca repetidas), ou quando querem presentar alguém que seja muito especial, que merece ganhar o vidrinho da consumidora-colecionadora (Figura 2.9).

Figura 2.9: As "viciadas" em esmalte exibem suas coleções e unhas em blogs e redes sociais.
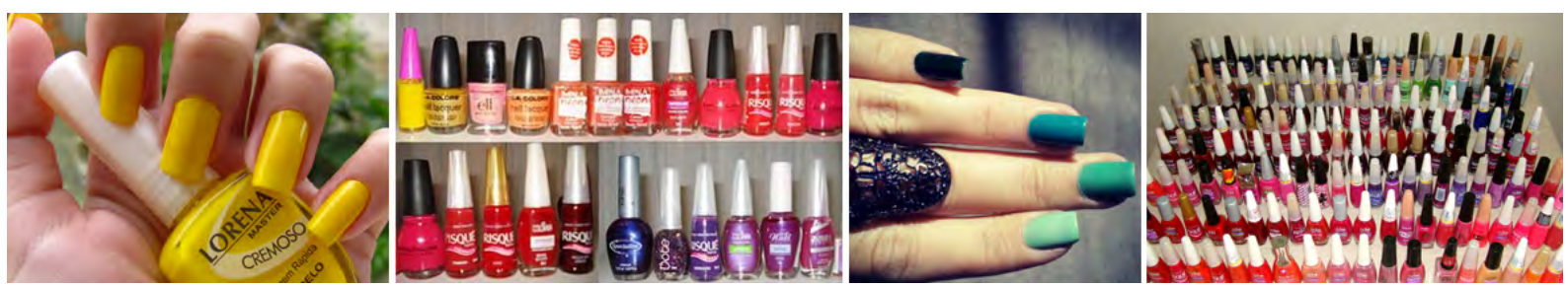

Fonte: Procura no Google por “minha coleção de esmaltes”, realizada em 5 de outubro de 2012.

Em estudo recente voltado para marcas de serviços (ambientação física de um restaurante), a cor-de-ouro influenciou a ação dos clientes - deixaram gorjetas maiores -, quando aplicada no porta-contas e na toalha de mesa (dourado vs. branco) (Lee, Noble, \& Biswas, 2016). Os autores explicam que o efeito no comportamento foi mediado pelos 
significados culturais aprendidos sobre a cor dourada, que conferiu ao restaurante e aos próprios indivíduos, um status de superioridade. Assim, signo-cor operou no modo apreciativo (para a marca e para o self do consumidor) e no prescritivo.

Os comportamentos evocados pelas cores não se restringem aos produtos acessíveis, como esmaltes de inúmeras cores, fãs pedindo por lençóis roxos, ou a compra e uso da moda fast-fashion, com uma peça em rosa-millennial ou verde-exército. As cores também provocam ações nos públicos do alto luxo, desde a falsificação das solas vermelhas Louboutin, ao colecionismo de bolsas que podem custar até $€ \$ 24$ mil:

Veja a simplicidade da caixa azul ou da caixa laranja [Tiffany ou Hermès]... a natureza colecionável de algo é muito, muito pessoal.... Seja o mesmo item em muitas cores ou uma cor que seja muito exclusiva de uma marca....

Veja a Hermès, eles têm uns rouges diferentes, um azul-jeans, em couro, em pele de lagarto, que são proprietárias. Cores que estão nas bolsas há décadas. É definitivamente sobre esse sentimento de comprar os valores da marca que vêm com as cores. (Depoimento de especialista - Louboutin)

Figura 2.10: O vermelho como signo que designa, aprecia e prescreve a Louboutin. (a)
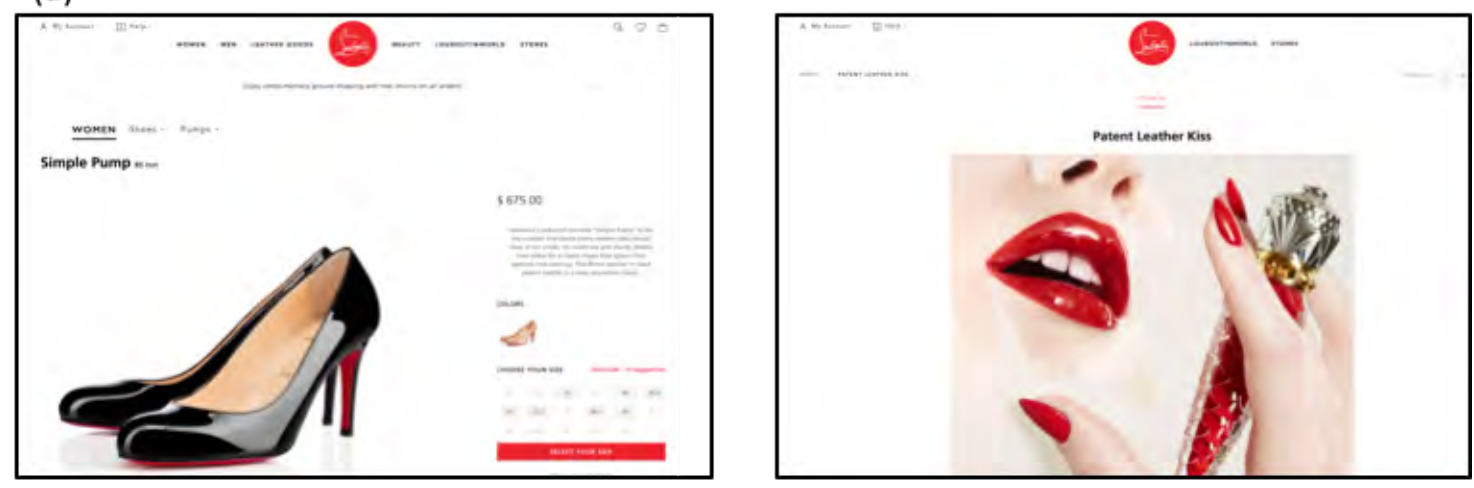

(b)
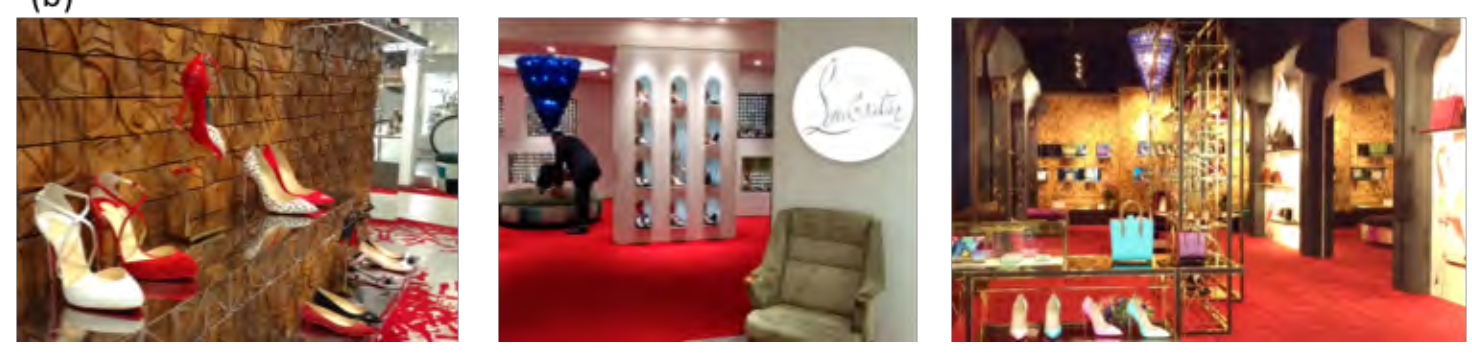

Fontes: (a) Site/loja virtual (Louboutin, 2017); (b) Visitas de observação nos lajas de Nova York e Miami.

O caso de personalização dos sapatos à la Louboutin, ou falsificação caseira (numa possível perspectiva corporativa), vale a pena ser analisado A cor vermelha identifica a maison francesa de luxo (Figura 2.10), fundada em 1992, sem a necessidade de logotipo ou outro 
elemento marcário (modo designativo da cor) quando aplicada nas solas dos sapatos. Usada por celebridades frequentadoras dos "tapetes vermelhos", a marca é fortemente associada com alto status, beleza e poder, valores desejados e impregnados no vermelho do solado (modo apreciativo da cor vermelha significar Louboutin).

Figura 2.11: Tutoriais sobre como pintar as solas à la Louboutin.
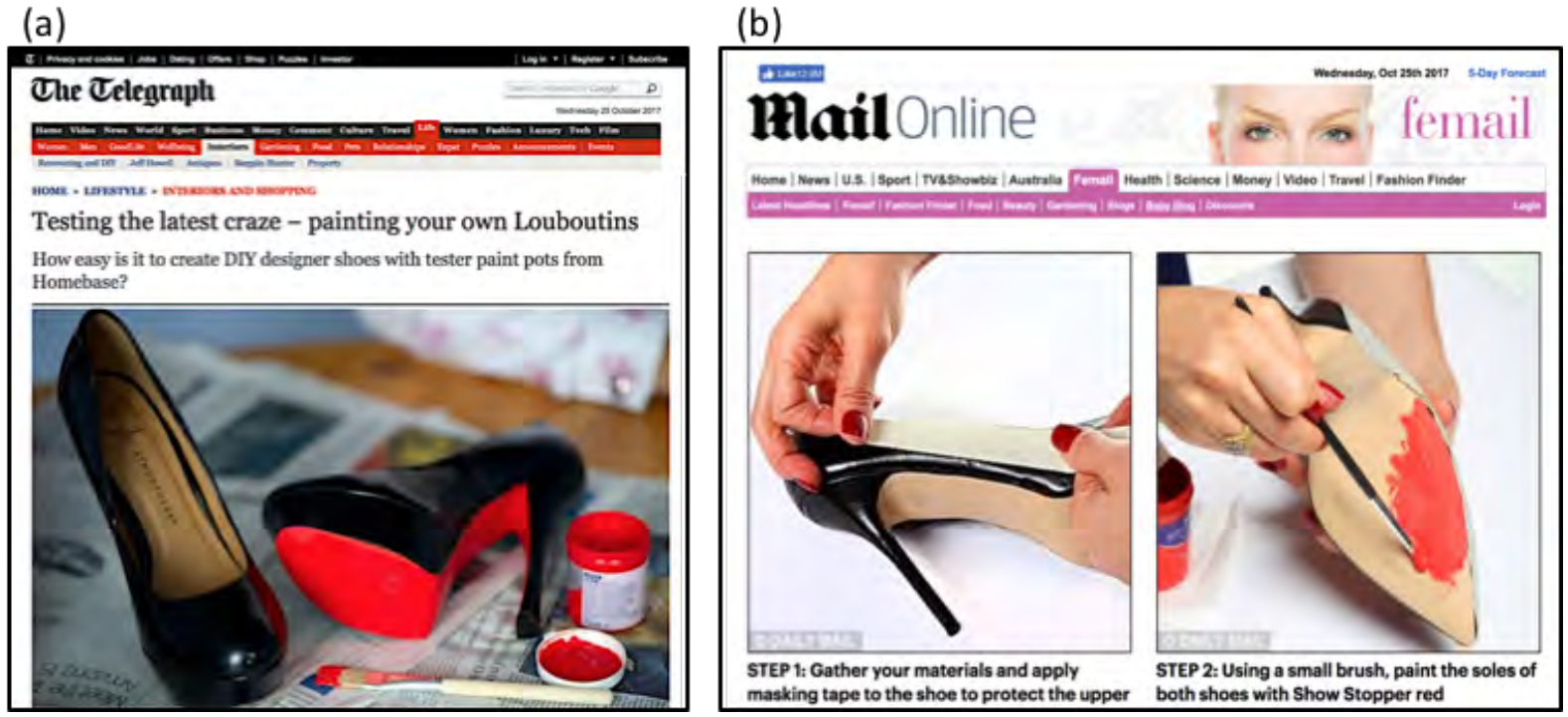

Fontes: Jornais (a) The Telegraph (Cooper, 2012) e (b) Daily Mail (Lacey, 2012).

Os indivíduos que desejam, mas não possuem U\$ 675 para adquirir um par de escarpins (preço de outubro/2017), contornam o problema pintando as solas dos seus sapatos baratos (Figura 2.11), o que aumentou em $40 \%$ a venda de tinta esmalte vermelha em uma rede de lojas inglesa (G. Cooper, 2012). Na época, reportagens sobre moda deram as dicas para as leitoras executarem a tarefa da melhor maneira possível (Lacey, 2012). Assim, o signo-cor vermelho opera para Louboutin também no modo prescritivo, dispondo seus públicos a duas ações distintas: comprar produtos da marca (indivíduos de maior poder aquisitivo) e pintar produtos de outras marcas (indivíduos sem o poder de compra suficiente).

Em entrevista, uma fã da marca Louboutin, Claire Stevenson, de 24 anos, confessou:

Não havia como eu comprar um par de sapatos Louboutin, mas meu coração estava neles e senti a pressão para estar na moda, em uma ocasião. Eu comprei um par de sapatos pretos lisos, por $£ \$ 20$, e uma lata de amostra de tinta, para recriar o look Louboutin em casa. Eu cuidadosamente pintei as solas, deixei secar durante a noite e no dia seguinte, estavam prontos para usar... Recebi muitos elogios no casamento..., mas não tive coragem para confessar que eu os havia falsificado. Foi tal o sucesso que planejo fazer o mesmo, com outro par de salto-alto. (The Telegraph Online, 2012) 
Sob o ponto-de-vista da gestão e comunicação de marca, compreender a dimensão prescritiva das cores é fundamental para as empresas atingirem seus objetivos estratégicos. Considerando a perspectiva do consumidor, da cultura e da crítica do branding (Schroeder, 2017), o entendimento da potência sígnica apreciativa e prescritiva pode colaborar para um melhor letramento visual do indivíduo-consumidor, possibilitando uma reflexão mais ampla sobre os valores e ideologias naturalizados por textos visuais e que, assim, ele possa ser mais consciente sobre as imagens e marcas que consome, produz e faz circular ao longo da vida.

\section{QUESTÃO 5 DA TESE:}

\subsection{A cor altera disposições prévias sobre uma marca?}

A dimensão formativa de significação ocorre por formadores (formators), "signos lógicos" ou "signos formais" que alteram a significação de combinações prévias de signos, quando adicionados a elas (Morris, 1946, p. 86). Por exemplo, são signos formadores os termos “ou”, “( )”, sufixos, sinais de operação matemática “+”, “\%”, e sinais de pontuação (“?", “!”), ou seja, signos que transformam a maneira que uma combinação sígnica (um ascriptor) significa como um todo. De acordo com Morris, o modo formativo de significação é o mais difícil e controverso, a ponto de ser recusado por alguns semioticistas (é negligenciado, por exemplo, em Holbrook \& Hirschman, 1993, p. 6). A polêmica extrapola o questionamento da existência da dimensão formativa de significação, e contesta também se os tais signos formadores seriam, de fato, signos - ou apenas elementos auxiliares.

Repensar o modo formativo para as cores e marcas demanda flexibilidade em relação à teoria original Morrisiana. Em primeiro lugar, Morris define um signo formador como um estímulo adicionado a combinações sígnicas, de tal maneira que ele não é um signo lexical - ele mesmo não designa, não aprecia, nem prescreve -, mas altera as significações designadas, apreciadas e prescritas pelos signos lexicais da combinação sígnica (Morris, 1946, p. 87). Assim, o signo formador seria "um tipo distintivo de signo" (1946, p. 161), que significa em apenas um modo, e diferente dos demais (1946, p. 88).

Considerando as especificações acima, a cor não poderia operar no modo formativo de significação. Conforme discutido, o signo-cor é incontestavelmente um designador da marca e de seus atributos. As cores não obrigatoriamente provocam um status de preferência (modo 
apreciativo), nem impreterivelmente evocam uma ação (modo prescritivo), em um indivíduo. Mas sempre caracterizam uma marca a seus públicos (sempre operam no modo designativo).

Em segundo lugar, e contraditoriamente ao primeiro ponto, Morris defende a interdependência dos modos e afirma que um mesmo signo pode significar em mais de um modo, concomitantemente (1946, p. 89). Nesse aspecto, esta tese ousa e propõe que as cores, em situações especiais, operam em um modo análogo ao modo formativo de Morris. Apoiando essa ousadia, o semioticista "discípulo" e especialista na tipologia Morrisiana do discurso, Fiordo (1977), desconstrói a ideia que um signo formador opera exclusivamente no modo formativo:

Como um de seus estudiosos, considero que o modo formativo [também] designa, avalia e prescreve.... Por exemplo, se $p$ implica $q$ e q implica r, então $p$ implica r. Sim, este é um padrão lógico no qual poderia se usar uma seta apontando da esquerda para a direita $(\Rightarrow)$ ou um símbolo similar. Esse modo formativo lógico está designando uma forma lógica válida, avaliando-a favoravelmente e prescrevendo que a utilizemos [inclusive] em um modo de raciocínio falacioso: por exemplo, se $p \Rightarrow q$ e $q \Rightarrow r$, então $p \Rightarrow z$. Você vê onde quero chegar? Os indicadores lógicos [signos formadores] "e", "ou", "se, e somente se" etc. têm funções designativas, apreciativas e prescritivas. ${ }^{21}$ (Fiordo, em e-mail pessoal para a autora, 10 de abril de 2017)

Para propor um modo correlato ao formativo, esta tese ajusta a definição original de signo formador, "um tipo distintivo de signo" (Morris, 1946, p. 161) para "uma cor distintiva", uma cor (ou combinação de cores) diferente que até então não pertencia à paleta cromática da marca. Adaptando e renomeando o modo formativo Morrisiano, tem-se a quinta proposição da tese:

\section{Proposição 5: a cor significa a marca no modo transformativo (transformative mode)}

Uma cor diferente (ou uma nova combinação de cores), aplicada em elementos e materiais marcários, significa uma marca no modo transformativo quando altera as prévias disposições evocadas nos públicos em relação a essa marca, pelas cores originais (ou anteriores) da paleta marcária, que operam nos modos designativo, apreciativo e /ou prescritivo.

\footnotetext{
21 "As one of his scholars, I think the formative mode does designate and appraise and prescribe...For example, if $p$ implies $q$ and $q$ implies $r$, then $p$ implies $r$. Yes, this is a logical pattern that may use an arrow pointing from left to right $(>)$ or a similar symbol. The formative discourse of this logical pattern designates a valid logical form, appraises it favorably, and prescribes that we use it over a fallacious form of reasoning: for example, if $p>q$ and $q$ $>$ r, then $p>$ z. Do you see what I am getting at? Logical indicators for "and," "or," "if and only if," and so on have designative, appraisive, and prescriptive functions".
} 
O prefixo "trans" foi adicionado ao modo "formativo" de significação de Morris, com dois intuitos. Primeiramente, para reforçar que ao operar no modo transformativo, a nova cor transforma (modifica) as disposições previamente estabelecidas, quando adicionada à paleta cromática da marca. O modo transformativo das cores é um modo de "re-significação" das marcas, alterando os efeitos de sentido até então operantes.

Em segundo lugar, o prefixo de origem latina "trans"2", - "além de", "para lá de"; "depois de" - conforme usado na acepção de transformar, transpor, transitar, transigir, passa a ideia de movimento, de efemeridade, de um estado temporário até uma nova situação conciliadora. O modo transformativo das cores ressignificarem marcas é transitório, dura enquanto as disposições evocadas pela(s) nova(s) cor(es) conflitar(em) com as disposições evocadas previamente - seja por materiais de marca antigos ainda em circulação (embalagens, produtos, propagandas, postagens nas redes sociais, etc.), seja pelo efeito na memória do intérprete. Quando as cores e as disposições antigas desaparecem do olhar e da mente dos consumidores, individual ou coletivamente, a ressignificação completou-se e a(s) nova(s) cor(es) passa(m) a ser as cores da marca, operando nos modos designativos, apreciativo e prescritivo sem a interferência do efeito transformativo.

\section{Mudança e disrupção: a cor que inova}

Quando decide alterar as cores dos seus produtos, logotipos, embalagens, etc., a marca deve estar ciente dos riscos potenciais do modo transformativo de significação. Segundo o fenômeno conhecido como "efeito da mera-exposição" (Zajonc, 1968), a mera exposição repetida de um estímulo acessível à percepção do indivíduo, influencia esse a gostar mais do estímulo. Assim, o modo atentivo (tornar as materializações percebíveis visualmente), o modo designativo (caracterizar cromaticamente a marca) e o modo transformativo (alterar as cores da marca já reconhecidas) têm direta influência nas emoções, atitudes (modo apreciativo) e comportamentos (modo prescritivo) que uma cor provoca nos públicos da marca - os consumidores tendem a gostar mais do que já viram anteriormente, do que lhes é conhecido.

Com a alteração das cores, um estranhamento/desfavorecimento em relação a marca é esperado. Por exemplo, um fabricante de sopa mudou o tradicional vermelho da embalagem

\footnotetext{
22 Da preposição Latina trans: "além de", "para lá de”; "depois de”, segundo Dicionário Português Oxford University Press @ 2012 Editora Objetiva. Versão eletrônica para Macintosh.
} 
para o verde, o que confundiu seus clientes e gerou uma queda nas vendas (Garber, Burke, \& Jones, 2000, p. 6). A prática do mercado evidencia a complexidade da questão para além da embalagem, envolvendo marcas de produto ou serviço, indiferentemente da categoria:

Às vezes, o que parece arriscado no início, depois torna-se absolutamente comum, como a Coca-Diet. Eles mudaram, de tradicionalmente uma lata muito vermelha para um design todo em prata.... Foi muito chocante... no início, as pessoas ficaram muito desconfortáveis... depois se tornou um caso extremamente bemsucedido, aumentou as vendas globais de Diet Coke. Uma embalagem muito diferente. (Depoimento de especialista - Interbrand)

O McDonald's está em um esforço para atualizar a experiência, criar um interesse visual para quem está na rua e aumentar a visibilidade dos arcos dourados. Então, o fundo preto que você viu em Nova York, o fundo verde que você viu na Europa, foram um esforço para apresentar a marca de uma maneira menos promocional, para tornála mais discreta do que foi no passado. (Depoimento de especialista - McDonald's).

Quando uma marca muda de cor em um rebranding, isso pode realmente chatear as pessoas, se for muito diferente [...]. As pessoas estão emocionalmente ligadas, e você não pensou nelas. Você deuIhes algo que elas não se importam, e você sabe como as pessoas podem fazer barulho! (Depoimento de especialista - Interbrand)

Curiosamente, são vários os exemplos de cores operando no modo transformativo para marcas da indústria de alimentos e bebidas, possivelmente pela constante necessidade de se diferenciarem em um mercado tão competitivo. A Crystal Pepsi Figura 2.12), de 1992, foi uma versão acromática do refrigerante amarronzado, lançada com intenção de evocar "pureza", em uma época que estava na moda as versões transparentes de produtos tradicionalmente coloridos, como sabonete e gasolina (Feloni, 2016). Porém, o acromatismo e a transparência provocaram sensações sinestésicas, evocando a percepção de uma Pepsi mais leve e "sem gosto" (Garber Jr., Hyatt, \& Starr, 2003; Haig, 2003, pp. 47-49). Pode-se entender o ocorrido pelas interferências do modo transformativo da "não-cor" sobre o modo designativo (de atributo) do marrom tradicional dos refrigerantes de cola. A nova "não-cor", porém, não venceu o conflito sígnico: a versão foi descontinuada e extinta do mercado dois anos após o lançamento. 
Figura 2.12: Embalagem e cenas do filme de lançamento da Pepsi Crystal.

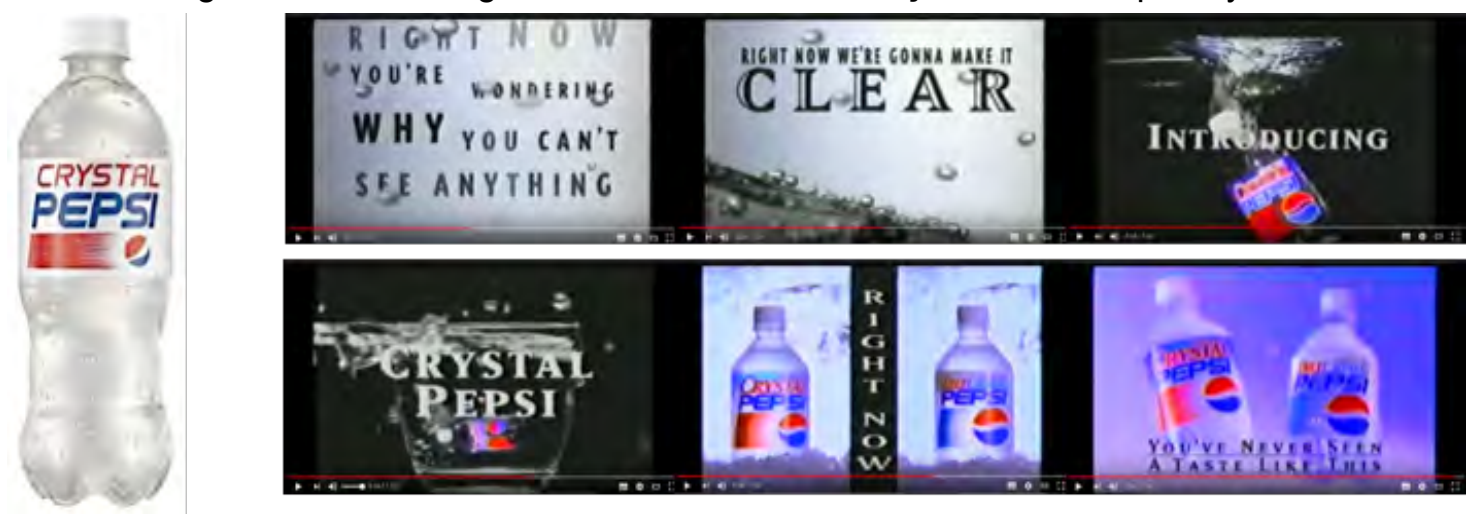

Fonte: Jornal online Business Insider (Feloni, 2016).

Um caso de sucesso foram as versões coloridas incomuns de ketchup Heinz, comercializadas de 2000 a 2006: a embalagem e o produto foram coloridos de verde, roxo, azul, laranja ou rosa, em substituição ao tradicional vermelho-tomate da categoria (Figura 2.13). A produção foi interrompida quando os clientes se "acostumaram" com o diferente, e perderam o interesse (BBC News, 2000, 2003; CBS News, 2017; USA Today, 2003).

(a)

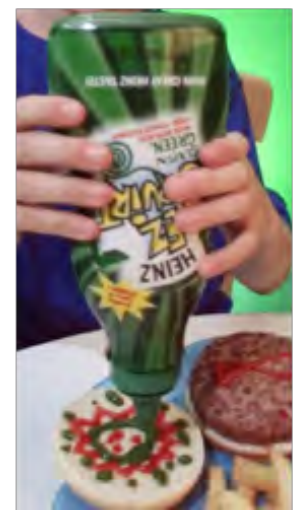

Figura 2.13: As embalagens e o ketchup colorido da Heinz.

(b)

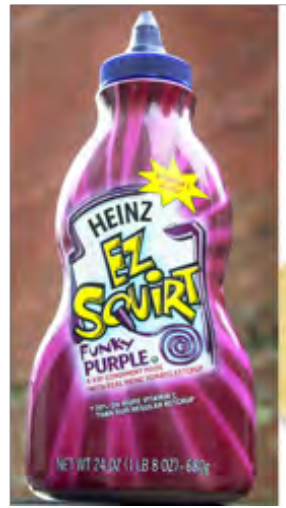

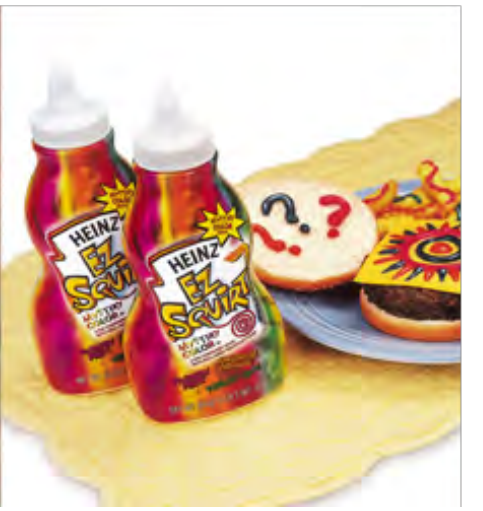

(c)

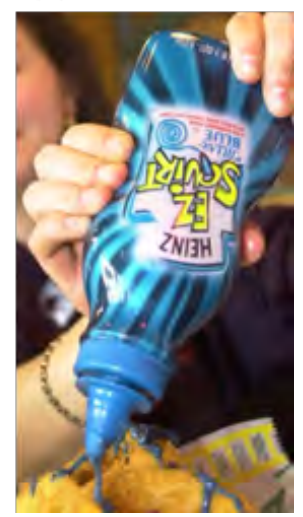

Fontes: Jornais (a) BBC News (2000); (b) CBS News (2017); (c) USA Today (2003).

Uma ocorrência recente do modo transformativo da cor é o caso da marca Personal Vip, que lançou no mercado brasileiro um papel higiênico preto, em outubro de 2017. O efeito sígnico da cor sobre o público, de forma geral, sofreu interferência de outro signo marcário, a hashtag "Black is Beautiful" (Figura 2.14a). Sob a acusação de se apropriar, banalizar e esvaziar o mote do movimento afro-americano da década de 1960 do seu sentido original e revolucionário, a marca rapidamente retirou o slogan da campanha e alterou os posts e o site no mesmo dia do lançamento (Figura 2.14b). 
(a)

Figura 2.14: Site (a) antes e (b) depois da alteração; Telas do (c) Instagram e (d) WhatsApp.

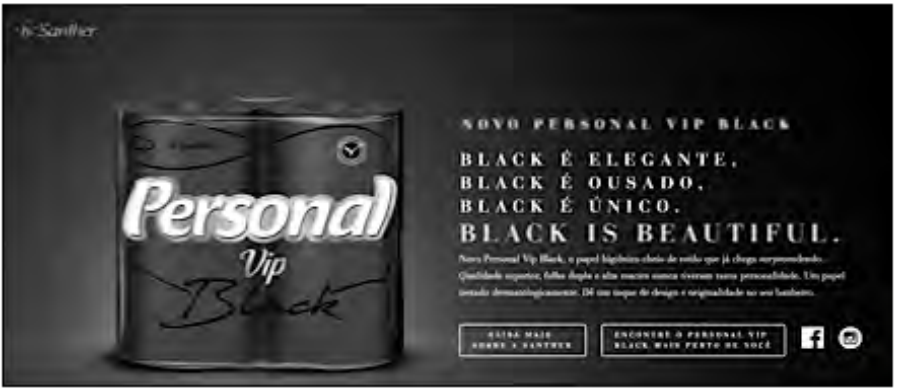

(b)

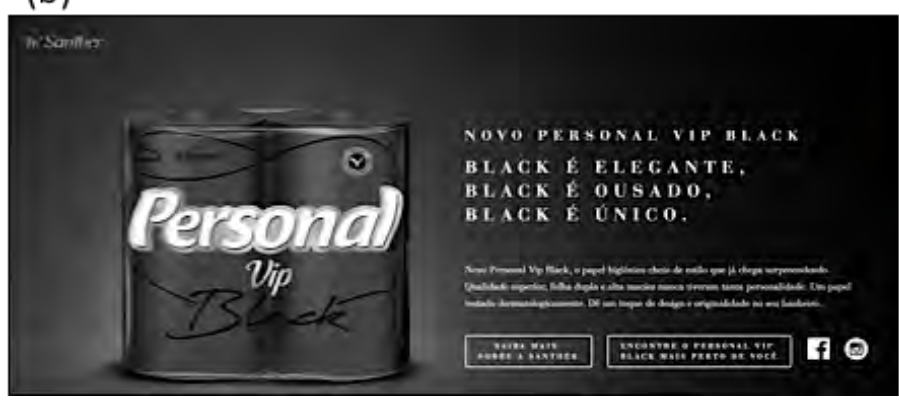

(c)

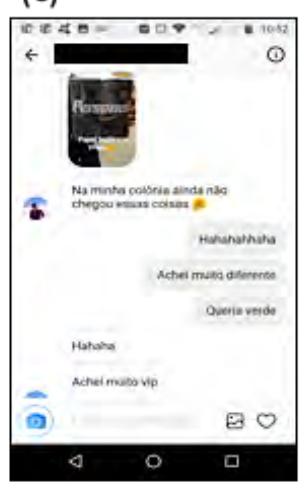

(d)

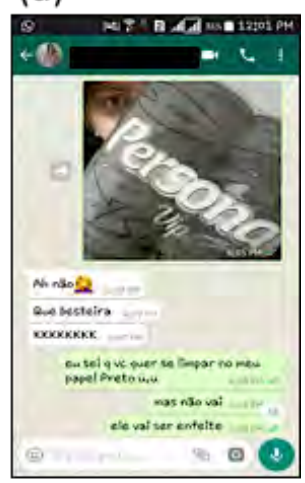

Fontes: (a, b) Site oficial da marca (Personal, 2017); (c, d) Telas captadas em comunicação pessoal, do celular da pesquisadora.

Mesmo com a ação rápida da empresa, a carga sígnica apreciativa desfavorável já havia se atualizado na mente dos intérpretes, e desencadeou uma série de engajamentos também negativos, como a discussão entre consumidores sobre o racismo revelado e postagens críticas sobre o aspecto pouco funcional do papel preto, na limpeza íntima.

Entre os contatos pessoais desta autora, dois jovens alunos postaram em suas redes sociais a compra do produto, antes de saberem sobre o desastroso uso do mote. Felipe, de 26 anos (Figura 2.14c), postou no Instagram Stories: "Achei muito diferente, queria em verde". $\mathrm{O}$ seu amigo respondeu: “Achei muito VIP”. A Aline, de 22 anos, que exibiu a posse postando em um grupo de WhatsApp (Figura 2.14d), foi debochada por um dos seus contatos: " $k k k k$, que besteira". Ela rapidamente contestou: "Eu sei que vc quer se limpar no meu papel preto $u^{o} u$, mas não vai, ele vai ser enfeite".

As postagens revelam os efeitos da cor preta aplicada no papel higiênico: o modo transformativo evocando um estranhamento; o apreciativo evocando luxo, qualidade e exclusividade não comuns na categoria de papel higiênico; e o prescritivo fazendo-os comprar, exibir e usar o papel como enfeite, claramente transformando um consumo cotidiano em rituais de compra, posse e arrumação. Porém, a cor preta aparentemente não operou em um nível de 
designação de marca, mas como designadora do produto: o bem material foi referenciado como "papel”, em um dos diálogos acima. Talvez, com o uso, o efeito ocorra, para a marca Personal VIP.

Conforme discutido, ao almejar os benefícios de chamar a atenção, obter preferência ou renovar sua imagem, a ressignificação provocada pela troca de cores é arriscada: pode causar falta de identificação com a categoria, ou da própria marca, desconsideração e rejeição do público. Os potenciais efeitos da alteração cromática, vantajosos e prejudicais, devem pesar sempre na balança das decisões sobre o uso das cores pelas marcas.

\subsection{Síntese dos modos de significação do signo-cor}

Os cinco modos de significação de Morris (1946) foram originalmente concebidos para qualquer tipo de signo, mas são de especial aplicação e interesse da semiótica textual (Nöth, 1990, p. 48). Aqui, ao serem repensados, dois dos modos foram renomeados a fim de adequá-los ao contexto visual das cores e marcas (Quadro 2.2).

Quadro 2.2: Proposição dos modos das cores significarem marcas.

\begin{tabular}{|c|c|c|c|}
\hline \multicolumn{2}{|r|}{$\begin{array}{l}\text { PROPOSIÇÕES SOBRE OS MODOS DAS CORES } \\
\text { SIGNIFICAREM MARCAS, PARA SEUS PÚBLICOS }\end{array}$} & $\begin{array}{l}\text { MODOS DE } \\
\text { (RE*) SIGNIFICAÇÃO DAS } \\
\text { CORES PARA MARCAS }\end{array}$ & $\begin{array}{l}\text { MODOS ORIGINAIS } \\
\text { DE SIGNIFICAÇÃO } \\
\text { (MORRIS,1946) }\end{array}$ \\
\hline P1 & $\begin{array}{l}\text { A cor evoca uma disposição para localizar a } \\
\text { marca em um espaço específico. }\end{array}$ & $\begin{array}{l}\text { MODO } \\
\text { ATENTIVO }\end{array}$ & $\begin{array}{l}\text { MODO } \\
\text { IDENTIFICATIVO }\end{array}$ \\
\hline P2 & $\begin{array}{l}\text { A cor evoca uma disposição para reagir como } \\
\text { se a marca tivesse características específicas. }\end{array}$ & $\begin{array}{l}\text { MODO } \\
\text { DESIGNATIVO }\end{array}$ & $\begin{array}{l}\text { MODO } \\
\text { DESIGNATIVO }\end{array}$ \\
\hline P3 & $\begin{array}{l}\text { A cor evoca uma disposição } \\
\text { positiva/negativa em relação à marca }\end{array}$ & $\begin{array}{l}\text { MODO } \\
\text { APRECIATIVO }\end{array}$ & $\begin{array}{l}\text { MODO } \\
\text { APRECIATIVO }\end{array}$ \\
\hline P4 & $\begin{array}{l}\text { A cor evoca uma disposição para agir em } \\
\text { relação à marca. }\end{array}$ & $\begin{array}{l}\text { MODO } \\
\text { PRESCRITIVO }\end{array}$ & $\begin{array}{l}\text { MODO } \\
\text { PERSCRITIVO }\end{array}$ \\
\hline P5 & $\begin{array}{l}\text { A cor evoca uma disposição para alterar as } \\
\text { disposições prévias em relação à marca. }\end{array}$ & $\begin{array}{c}\text { MODO } \\
\text { TRANSFORMATIVO* }^{*}\end{array}$ & $\begin{array}{l}\text { MODO } \\
\text { FORMATIVO }\end{array}$ \\
\hline
\end{tabular}

Fonte: Desenvolvido pela autora. *Modo de ressignificação. Modos renomeados do original de Morris.

A renomeação dos modos de significação originais de Morris é apoiada por Fiordo, que indagado sobre essa possibilidade, comentou: 
assim por diante. Ciência e conhecimento avançam. Considere as organizações conhecidas, como por exemplo, The Society for the Advancement of Science. A ciência precisa e deve avançar. Então, os termos semióticos que Morris usou em meados do século XX, provavelmente seriam modificados se pudéssemos ter uma linha de bate-papo celestial com ele, hoje. ${ }^{23}$ (Fiordo, em e-mail pessoal para a autora, 10 de abril de 2017)

A confrontação entre os conhecimentos acadêmicos e as práticas de mercado, realizada neste capítulo, revelou que as empresas, agências e consultorias estão cientes dos efeitos potenciais das cores sobre os públicos da marca, em maior ou menor profundidade. Nas entrevistas, os profissionais especialistas declararam não poderem expor os resultados dos testes, nem os números sobre o desempenho de mercado, que possuem, por questões estratégicas, competitivas. Ao contrário do que a literatura acadêmica da mercadologia sugere (que as decisões sobre as cores seriam tomadas sem pesquisa e baseadas em conhecimento anedótico), as empresas dedicam tempo e dinheiro para desenvolver e testar suas ideias, incluído o uso das cores. Isso não impede, para infelicidade delas, que aconteçam falhas. Aprender com o erro não é exclusividade da Academia.

\section{Modos de significação e os estudos atuais do comportamento humano}

Os efeitos que o signo-cor é capaz de evocar nos intérpretes foram aqui apresentados e discutidos seguindo a ordem proposta por Morris (1946), que mostra "um implícito paralelo com a antiga tricotomia da cognição-afeto-conação de Platão, encontrada nos modelos tradicionais de processamento da informação dos estudos do comportamento do consumidor" (Holbrook, 1987, p. 78). O modo designativo de significação relaciona-se com a fase cognitiva (pensar), o modo apreciativo com a fase afetiva (sentir), o modo prescritivo com a fase conativa (intenção de fazer e o fazer, propriamente).

Em sua teoria, Morris não fixou a ordem sequencial dos efeitos interpretantes (designar, apreciar, prescrever), embora defendesse que "frequentemente" um baseava-se no outro, anterior (Morris, 1946, p. 103). Diferentemente, os primeiros modelos da hierarquia de respostas do consumidor - de certo modo contemporâneos à tipologia dos discursos e a outro trabalho de

\footnotetext{
23 "... knowledge is ongoing. What we think we know in 1900 is not what we think we know in 1950, 2000, 2050, and so on. Science and knowledge advance. Think of the organizations known as The Society for the Advancement of Science. Science must and should advance. So, semiotic terms Morris used in the middle of the 20th Century would likely be modified if we were able to have a heavenly chat-line with him today".
} 
Morris, Signification and Significance (1964) -, sequenciaram fixamente os possíveis processos mentais e comportamentais de um indivíduo, quando exposto à propaganda e demais comunicações mercadológicas: um caminho que vai desde o total desconhecimento até o comprar, seguindo uma metáfora de "funil de compras". Por exemplo, o modelo AIDA-Atenção, Interesse, Desejo, Ação (Strong, 1925, apud Belch \& Belch, 2008) ${ }^{24}$; o modelo de hierarquia dos efeitos de Lavidge e Steiner (1961); e o modelo clássico do processamento de informações de McGuire (1978).

Apesar da incontestável importância dos três estágios da hierarquia, estudos posteriores questionaram a fixidez da ordem cognição-afeto-conação e propuseram novas teorias, defendendo todas as seis possíveis combinações (não repetindo) das três etapas (Barry \& Howard, 1990). Como exemplo, uma das primeiras teorizações alternativas é a de Ray et al. (1973), que desenvolveram com três modelos em novos ordenamentos hierárquicos: o modelo de aprendizagem (o clássico aprender-sentir-fazer), o modelo de dissonância/atribuição (fazersentir-aprender); e o modelo de baixo envolvimento de compra (aprender-fazer-sentir). A comparação entre os modos Morrisianos e os modelos de hierarquia de respostas do consumidor, clássicos e alternativos, é esquematizada no Quadro 2.3.

Hoje em dia, os estudos sobre o comportamento do consumidor, especialmente dedicados a olhar as respostas dos indivíduos às comunicações marcárias, trabalham com modelos mais complexos, e levantam questões sobre a dificuldade de distinção e mensuração de cada etapa, em especial cognição e afeto. Nas pesquisas atuais, as atividades mentais são sabidas como dinâmicas, constantes, altamente interdependentes (quando não simultâneas) - o que Morris já dizia há mais de 70 anos, na sua teoria de modos de significação.

Finalizando, o capítulo definiu quatro modos de significação marcária pelas cores, e um modo de ressignificação. A cor capta o olhar e a atenção dos públicos, evoca (e transforma o anteriormente evocado) características, atitudes e comportamentos, em diferentes gradações de intensidade, e sempre em função de um contexto mercadológico (cores do ambiente competitivo) e sociocultural (associação das cores com valores culturais e respostas fisiobiológicas). Como e com quais intenções estratégicas as marcas exploram as dimensões sígnicas das cores é o assunto do próximo capítulo.

\footnotetext{
${ }^{24}$ Atualmente acredita-se que o modelo foi originalmente criado em 1898, por Elmo Lewis.
} 
Quadro 2.3: Os três principais modos de significação Morrisianos comparados com vários modelos de hierarquia de respostas do consumidor, relativamente contemporâneos a Morris.
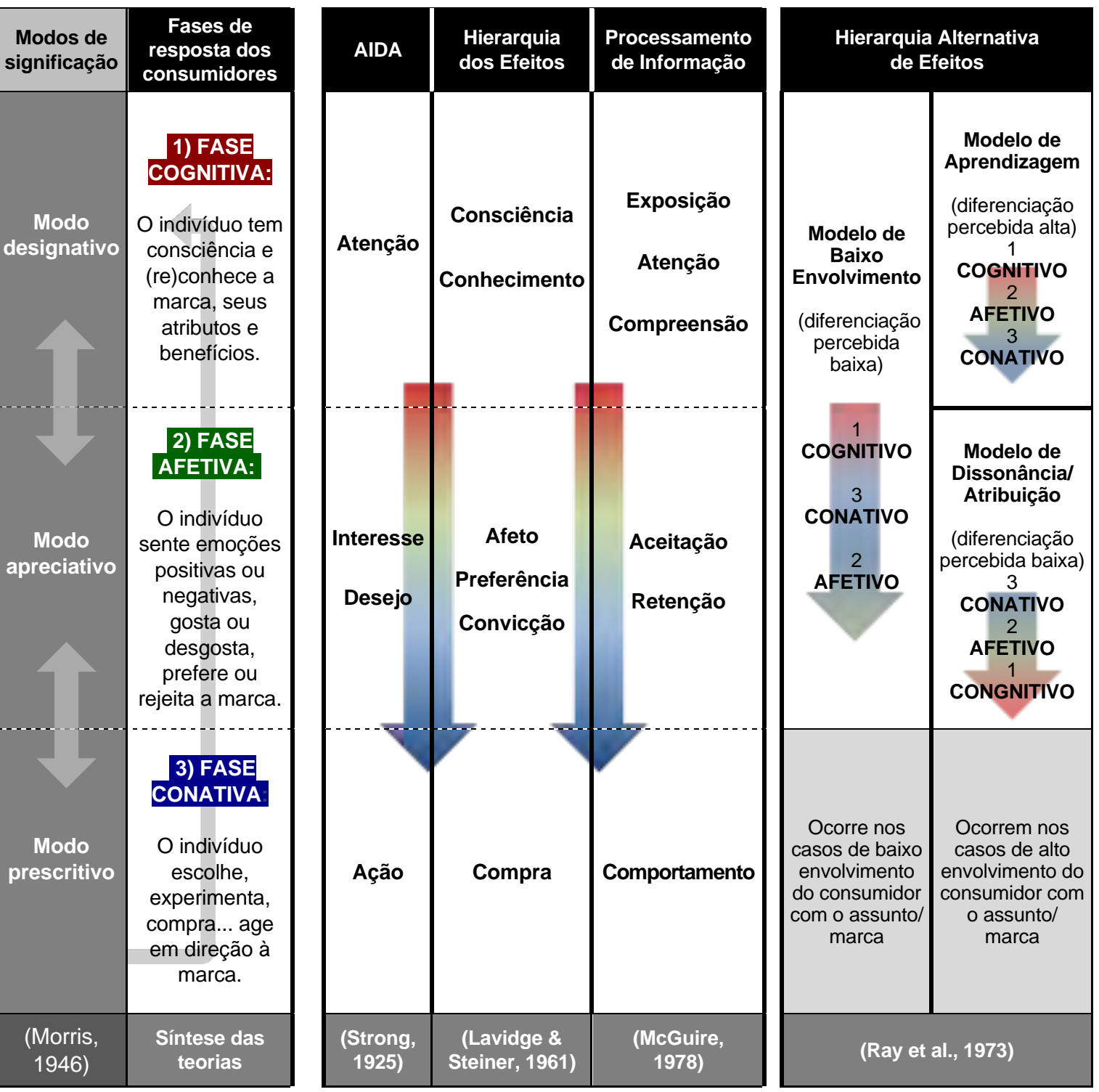

Fonte: Desenvolvido pela autora, adaptando autores e o esquema de Belch \& Belch (2008, pp. 146-149). 


\section{Usos da cor como signo de marca}

Nesse capítulo, a teoria dos usos sígnicos de Morris (1946) é repensada para a pragmática das marcas e cores. Morris estipulou quatro tipos gerais de uso sígnico, as intenções principais de um organismo ao produzir qualquer signo: uso informativo (signo cujo objetivo principal é informar), avaliativo (induzir alguém a preferências), incitivo (estimular ações específicas) ou sistêmico (organizar o comportamento induzido por demais signos do sistema). Qualquer outra função sígnica é um subtipo dos quatro primários (Morris, 1946, p. 95).

Morris diferencia os modos dos usos sígnicos ao explicar que um signo provoca respostas em um intérprete mesmo sem ter sido produzido por qualquer organismo, ou ao menos não com essa intenção. Aqui, a investigação focaliza os motivos e as maneiras das marcas (produtoras do signo-cor) utilizarem as cores, por vezes bem, por vezes malsucedidas. Baseadas nos quatro tipos gerais de uso sígnico, foram definidas quatro perguntas de pesquisa (ver seção 1.4.1.2 para detalhes) sobre as funções da cor na comunicação visual de marca, resumidas no Quadro 3.1:

Quadro 3.1: Questões de pesquisa sobre os modos de significação das cores.

\begin{tabular}{|c|c|c|c|}
\hline \multicolumn{3}{|c|}{$\begin{array}{c}\text { QUESTÕES DE PESQUISA SOBRE OS PRINCIPAIS OBJETIVOS } \\
\text { DA MARCA AO USAR O SIGNO-COR }\end{array}$} & $\begin{array}{l}\text { USOS DOS } \\
\text { SIGNOS, } \\
\text { MORRIS (1946) }\end{array}$ \\
\hline \multirow{4}{*}{$\begin{array}{c}\text { Por que } \\
\text { e como } \\
\text { a cor é } \\
\text { usada com } \\
\text { o objetivo } \\
\text { principal } \\
\text { de... }\end{array}$} & Q6 & $\begin{array}{l}\text {... informar convincentemente os públicos sobre as } \\
\text { propriedades da marca? }\end{array}$ & $\begin{array}{l}\text { USO } \\
\text { INFORMATIVO }\end{array}$ \\
\hline & Q7 & $\begin{array}{l}\text {... induzir eficazmente os públicos a estabelecerem uma } \\
\text { preferência em relação à marca? }\end{array}$ & $\begin{array}{l}\text { USO } \\
\text { AVALIATIVO }\end{array}$ \\
\hline & Q8 & $\begin{array}{l}\text {... incitar persuasivamente seus públicos a ação em } \\
\text { direção à marca? }\end{array}$ & $\begin{array}{l}\text { USO } \\
\text { INCITIVO }\end{array}$ \\
\hline & Q9 & $\begin{array}{l}\text {... (re) organizar corretamente as respostas dos } \\
\text { públicos previamente provocadas por outros signos, em } \\
\text { relação à marca? }\end{array}$ & $\begin{array}{l}\text { USO } \\
\text { SISTÊMICO }\end{array}$ \\
\hline
\end{tabular}

Fonte: Desenvolvido pela autora. 
A utilização de um signo, por um organismo, pode ser voluntária ou involuntária (Morris, 1946, p. 93). A cor pode ser utilizada pelos comunicadores, criadores e gestores com ou sem um propósito específico, cientes ou não dos efeitos que elas causam nos públicos de interesse. $\mathrm{O}$ uso da cor pode ser realizado adequadamente ou não, a depender da obtenção dos resultados almejados pelo produtor do signo. Seguindo o esquema de adequação do uso sígnico de Morris (1946, p. 97), o uso da cor é convincente quando informa adequadamente sobre a marca; é eficaz quando induz adequadamente a uma avaliação intencionada pela marca; é persuasivo quando incita adequadamente a uma ação desejada marca; e é correto quando organiza adequadamente o conjunto de disposições em relação à marca.

QUESTÃO 6 DA TESE:

\subsection{Por que e como a cor é usada para informar sobre a marca?}

Quando o propósito principal do uso de um signo é "fazer com que o intérprete responda como se algum objeto/situação presente, passado ou futuro tivesse tais e tais características" (Morris, 1946, p. 97), o signo está sendo usado informativamente - seja a informação sobre qualidades físicas, sobre estados preferenciais ou sobre necessidades. Embora signos operando em qualquer modo de significação possam informar, o uso informativo sempre envolve um signo no modo designativo: signos designadores sempre informam, e por isso é natural que seu uso primário seja informativo (Morris, 1946, p. 98).

Aplicando o uso sígnico informativo para o âmbito das cores e marcas, tem-se a proposição do uso informativo das cores:

\section{Proposição 6: o adequado uso informativo da cor promove a identificação da marca}

O uso informativo da cor (ou de uma combinação de cores), informa os públicos sobre uma marca. $\mathbf{O}$ uso informativo é convincente (informativamente adequado) quando a cor identifica uma marca, seus atributos e benefícios, aos públicos de interesse, que respondem como se ela tivesse as características informadas independentemente dessa informação ser verdadeira.

Conforme discutido, o signo-cor sempre opera como designador visual, da marca e/ou dos atributos da marca, evocando nos públicos características especificadoras. Ao serem 
aplicadas nos pontos-de-contato consistentemente e com exclusividade (entre os competidores), as cores podem se tornar identificadoras em um grau máximo da função informativa explorada como o mais importante elemento da manifestação visual (Schmitt \& Simonson, 2002, p. 109), como o principal componente do patrimônio visual (visual equity) marcário (Lightfoot \& Gerstman, 1998, pp. 69-70).

Usadas adequadamente na função informativa e em um grau máximo, as cores evocam a identificação específica de uma marca - a habilidade do consumidor de reconhecer e identificar um logotipo, um produto, uma embalagem, ou qualquer outro ponto-de-contato como pertencente a uma marca em particular (Garber et al., 2000). Nos contextos competitivos e saturados de signos e mensagens, das inúmeras opções no mercado, esse reconhecimento ou identificação por parte do consumidor é de grande valor no plano comunicacional da marca.

Estrategicamente, uma das razões pelas quais o amarelo e o
vermelho foram identificados como cores principais é porque são
instantaneamente reconhecíveis.... A psicologia por trás dessas duas
cores é uma combinação perfeita para a categoria, e é por isso que
você vê muitos competidores [fast-food] usando essas duas cores. O
otimismo e o brilho, o calor desse amarelo, a atratividade do amarelo.
E o vermelho é uma cor muito chamativa, e também cria um appetite
appeal. Do ponto de vista da psicologia da cor, essas cores são
importantes. (Depoimento de especialista - McDonald's)

São dois os fatores fundamentais para que as cores exerçam a função informativa de identidade de marca: a) uso consistente (imutável); e b) uso exclusivo (na categoria). O uso consistente é condição sine qua non para a cor apoiar a identificação, enquanto a exclusividade do uso da cor, no segmento específico, possibilita a diferenciação dos demais competidores, intensificando o desempenho informativo do signo-cor para uma determinada marca.

\section{Consistência: condição essencial para a cor identificar uma marca}

O uso clássico da cor para a identidade visual marcária é baseado na uniformidade e regularidade. Nele, a cor (ou combinação de cores) deve permanecer imutável e ser aplicada consistentemente ao longo do tempo, em todos os pontos-de-contato. Qualquer mudança no design (cor incluída) deve ser realizada com foco no "valor que irá agregar ao consumidor", de modo a "acentuar e radicalizar os sinais da individualidade da marca", tornar a marca mais protegida (de ser copiada pelos competidores) e mais facilmente reconhecível por seus públicos (Kapferer, 2012, p. 216). 


\begin{abstract}
A familiaridade das cores é o principal fator de familiaridade da marca. As empresas têm marcas registradas por um motivo. É preciso apresentar as marcas de forma consistente, para consistentemente familiarizar seus clientes. (Depoimento de especialista - McDonald's)
\end{abstract}

As cores da marca devem estar descritas no manual de identidade visual, incluindo eventuais cores secundárias e combinações cromáticas recomendadas. As instruções de uso com as especificações das cores nos sistemas CMYK, RGB, escala de cinzas e Pantone, permite a fidelidade na reprodução de cor, nos diversos suportes físicos (papel, tela de celular, tecido, plástico, etc.).

Nos casos de identidade visual mutante (Kreutz, 2007) ou cambiante (Kopp, 2002) na cor, as marcas abrem mão do uso informativo cromático para a identificação marcária. No segmento brasileiro de telecomunicações, Vivo e Oi (ver seção 2.2) não se apoiam nas cores para a identificação, enquanto a Claro, com o vermelho, e a Tim, com o azul, exploram o modo designativo das cores na função informativa de identidade.

$\mathrm{Na}$ prática do mercado, é possível observar o dilema entre desenvolver uma identidade cromática fixa ou abrir mão da identificação pela cor em troca de versatilidade. A fixidez parece ser a estratégia preferida dos especialistas, embora estejam cientes que a flexibilidade cromática é potencialmente útil para obter maior preferência pela marca (uso avaliativo das cores).

Em um mundo onde tudo é excelente... num mundo em que a concorrência pela atenção e os dólares dos consumidores é tão intensa, qualquer coisa que os faça questionar, por um momento, se você é a marca certa para eles, é um erro. Tudo o que você pode fazer para lembrá-los do seu valor e para que eles a mantenham no coração e mente, é positivo.

...

Eu acredito que a consistência na apresentação ainda é importante... [mas] existe um risco: ser consistentemente chato.

E é por isso que você tem que evoluir continuamente.

...

Mudanças são cativantes, provocadoras, mas é um risco que não vale a pena tomar. Meu conselho para pessoas criativas é focar sua criatividade no resto, não nas joias da empresa, porque elas [as cores da assinatura] são as joias.... Você não brinca com elas. E se você fizer isso, você faz muito intencionalmente, de uma maneira muito cuidadosa. (Depoimento de especialista - McDonald's) 
Nem todo verde é o verde da Universidade do Oregon, nem todo amarelo é o amarelo da UO! Pense na Tiffany, por exemplo. Existe apenas um azul Tiffany. E um tom diferente do azul não será mais o azul Tiffany.... Eu não consigo imaginar uma marca famosa mudando as suas cores. Não consigo.

Eu sou uma tradicionalista de marca. Para mim, quanto menos alterações, mais forte ela é. Mas isso está sendo desafiado agora. Se você olhar para 50 ou 60 anos atrás, a marca não mudava e tirava força disso... [veja] a identidade visual do time de futebol americano da Universidade do Oregon: a cada jogo, o time tem um diferente esquema de cor .... Não parece o time da UO, para mim. Mas os jovens gostam, parece inovador, moderno, contemporâneo. (Depoimento de especialista - University of Oregon)

\section{Diferenciação: o uso exclusivo da cor, pela marca}

Além do uso consistente, a diferenciação em relação aos competidores é outro aspecto relevante no uso informativo da cor para a identificação da marca. Nesse aspecto, a tática mais adequada é utilizar a cor mais diferente possível das usadas na categoria, e não escolhê-la em função das associações comumente estabelecidas em seu contexto cultural e competitivo: a cor provavelmente já é utilizada pelos concorrentes (Ries \& Ries, 2000, p. 97).

Os casos mais conhecidos de marcas que utilizam as cores com exclusividade na categoria são tratados na literatura como exemplares no desenvolvimento de identidade marcária distintiva: o Itaú com o laranja, a cor registrada "Tiffany Blue"; o vermelho aplicado nas solas, identificando exclusivamente os sapatos da marca Louboutin; o rosa em produtos e embalagens de isolamento termo-acústico da Owens-Corning; furgões, aviões e uniformes marrons, para UPS, e roxo e laranja para FedEx; verde e amarelo para a marca de equipamentos agrícola e florestal, John Deere; amarelo e preto para a Caterpillar; magenta forte para a TMobile e laranja para a Orange, no setor internacional de telecomunicações ${ }^{25}$. Geralmente, essas marcas utilizam apenas uma ou duas cores como assinatura visual.

Se você usar a cor como um elemento de diferenciação, com uma quantidade limitada de cores... quanto menos cor você tiver, mais proprietária a marca fica.... Se você representa alguma coisa e você

\footnotetext{
25 (Aaker, 1998; Batey, 2008; Birkner, 2016; Bucci, 2012; Cooper, 1996; Floch, 2000; Garber et al., 2000; Gorman, 2012; Grewach, 1985; Haig, 2003; Itaú, 2012; Kapferer, 2012; Karjalainen \& Snelders, 2010; Labrecque \& Milne, 2012; Lindstrom, 2005; Mazumdar, 2015; Miletsky \& Smith, 2009; Niemann, 2007; Olins, 2004; Ries \& Ries, 2000; The Fashion Law, 2015; Voight, 2003; Wallace, 2016).
} 
usa apenas um par de cores ou uma cor dominante, isso é único... e as pessoas têm essa maneira de se lembrar de você. Isso não acontece com o azul ou o vermelho, infelizmente, já há muitos lá fora. Quanto mais singular for a cor, mais vão se lembrar de você. $\ldots$

Talvez não gostem da cor, talvez ela não tenha a 'personalidade' certa, mas escolhendo propositalmente e bem, e uma gama ampla como cores secundárias, com mais complexidade, você pode ter a vantagem de ser mais distintivo. No meu ponto de vista... é muito benéfico ter um mínimo de 2 cores para ter algum tipo de tensão. Mas não é uma regra, porque as marcas têm personalidades diferentes... às vezes é a simplicidade e você pode ter menos cores. (Depoimento de especialista - FutureBrand)

O Itaú é um exemplo brasileiro de uso consistente e distintivo: o laranja tornou-se capaz de identificar a marca de modo quase autônomo (Figura 3.1). A cor é aplicada desde a década de 1980, nas fachadas das agências e nos totens de sinalização dos então inovadores caixas eletrônicos - quando o logotipo ainda era preto e branco e proporcionava pouco contraste com o entorno urbano (Itaú, 2012). Hoje, o logotipo do Itaú é colorido (azul e amarelo) e o laranja ascendeu como o principal elemento visual da marca, aplicado em profusão na miríade de manifestações visuais urbanas e midiáticas do banco.

(a)

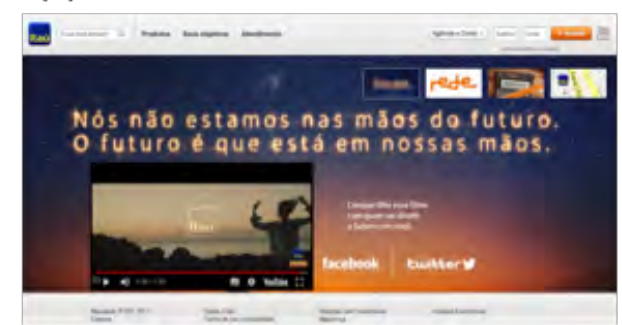

Fontes: (a) Sites oficial do banco (Itaú, 2017b); (b) Site da ativação de marca (Itaú, 2017c);(c) Hotsite corporativo (b)

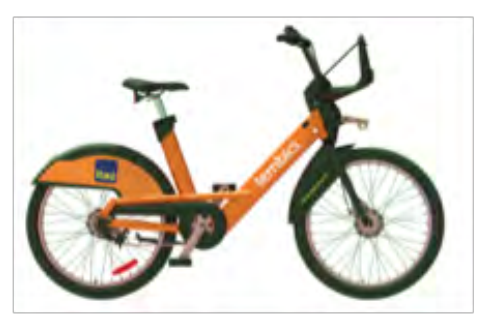

(c)

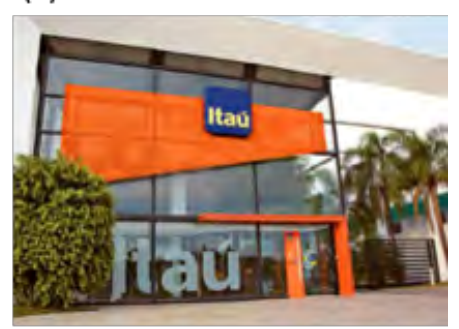
(Itaú, 2017d)

O caso é especialmente peculiar devido ao laranja não colorir o logotipo: é uma cor originalmente criada como cor de fundo. Normalmente, a combinação cromática principal de uma marca é aquela usada no logo, o "elemento básico para uma identidade visual consistente" (Allen \& Simmons, 2004, p. 118), graças à sua capacidade de síntese visual e simbólica.

As marcas possuem mais de uma versão de logotipo, sempre utilizando as cores oficiais (ou preto e branco, na impossibilidade de reprodução de cor): versão horizontal, vertical, em positivo (para fundos claros), em negativo (para fundos escuros), etc. Atualmente, porém, o número de variações dos logotipos se ampliou (Figura 3.2), incluindo versões 
simplificadas que identifiquem as marcas nas redes sociais ou em aplicativos móveis, com restrições de tamanho de reprodução.

Figura 3.2: Identificação visual da Nubank no (a) cartão de crédito; (b) site; (c) Facebook; (d) Instagram.

(a)

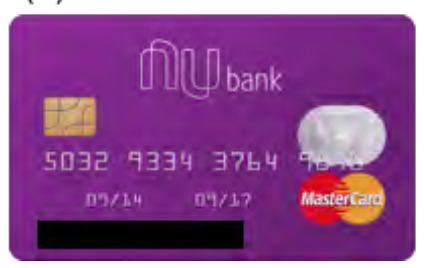

(b)

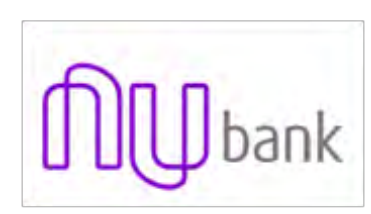

(c)

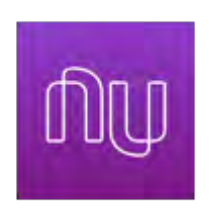

(d)

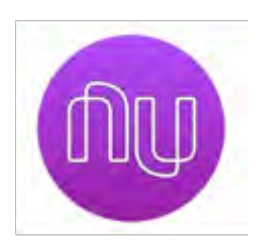

Fontes: (a) Acervo da pesquisadora; (b-d) Site (Nubank, 2017) e perfis nas redes sociais. Último acesso em 10/12/2017.

Recentemente, foi criado o termo e a tecnologia de "logos responsivos ${ }^{26 "}$ - responsive logos (Harrison, 2014) - referindo-se a logotipos que se adaptam automaticamente, como em uma animação, conforme mudam o tamanho, a resolução e a orientação da tela em que são visualizados (Figura 3.3). Nesses casos, enquanto as formas e detalhes gráficos (das letras, símbolos e acessórios) são reduzidos ou até excluídos, a paleta cromática é mantida, como um importante recurso para o reconhecimento da marca.

Figura 3.3: Propostas de logos responsivos para a Coca-Cola e Heineken.
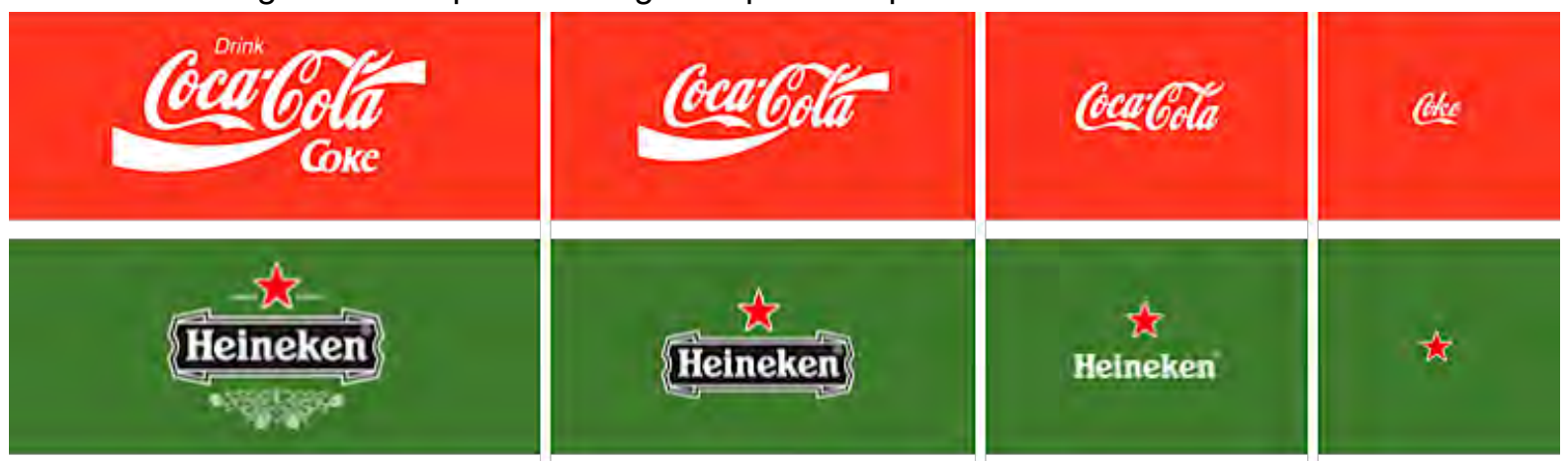

Fonte: Site Responsive Logos (Harrison, 2014).

\section{Confusão e imitação: a cor informando falsamente sobre a marca}

Segundo Morris, quando um signo "desinforma" o intérprete - o informa sobre algo não verdadeiro - ainda assim cumpre a função informativa, mesmo se o que está sendo informado

\footnotetext{
${ }^{26}$ Referente a "design responsivo", que redistribui e redimensionaliza os elementos de uma interface gráfica, conforme condições de visualização, seja em tela de 50 (televisores) seja em tela de 2 polegadas (celulares).
} 
não denota coisa alguma (Morris, 1946, p. 99). No contexto de mercado, são frequentes os usos da cor no intuito de identificar erroneamente uma marca, para os públicos de interesse.

A imitação deliberada do trade dress $^{27}$, é uma tentativa de apropriação da participação de mercado da marca melhor posicionada, por uma marca-clone não conhecida e/ou de desempenho inferior. A semelhança visual confunde o consumidor, que pode comprar a tal marca copycat (ou me-too) no lugar da líder, devido à imitação da cor, principal fator inconsciente de reconhecimento no ponto-de-venda - seguida pela forma da embalagem, o nome e a tipografia (Kapferer, 2012, p. 105).

Para evitar a cópia cromática, as empresas tentam patentear suas cores. Porém, no Brasil, o artigo 124 inciso VIII da LPI (Lei da Propriedade Industrial $n^{\circ}$ 9.279, 1996), impede a apropriação de uma cor isolada ou de seu nome, embora permita o registro de duas ou mais cores, em combinação peculiar e distintiva - desde que não tenha ligação funcional ou necessária com o produto ou serviço. Essa restrição, que ocorre no Brasil, não é comum internacionalmente: pesquisas de 2006 indicaram que 60\% dos países participantes da Organização Mundial da Propriedade Intelectual (OMPI) permitem o registro de uma cor isolada, desde que comprovada o secondary meaning (Portilho, 2009). O "significado secundário" é a associação entre a cor e uma marca específica, construída na percepção dos consumidores após o uso consistente e contínuo dessa cor.

Embora a legislação brasileira não permita o registro de uma cor como marca (permitido na Europa e Estados Unidos), ela concede registro para a combinação de uma cor com formas ou grafismos de uma embalagem, num conjunto de trade dress (Barbosa, 2013, p. 160). Esse posicionamento jurisprudencial permite interpretações múltiplas, verificadas nos casos de longas disputas judiciais. As decisões vêm reforçando a não exclusividade da cor por nenhuma empresa, exceto quando comprovado que "a cor tenha efetivamente adquirido distintividade pelo uso (secondary meaning) ou que desde sua origem possua uma associação distintiva capaz de indicar a procedência de produtos e serviços" (Aguillar, 2016, p. 46).

Um exemplo recente é o litígio entre as cervejas Itaipava e Brahma. A Ambev utiliza a cor para organizar as marcas do portfólio (ver uso sistêmico, seção 3.4): Skol com o amarelo, Antárctica com o azul, Brahma com o vermelho, desde 2010 (anteriormente branco e vermelho)

\footnotetext{
${ }^{27} \mathrm{O}$ termo jurídico, traduzido como "imagem-conjunto", se refere às características visuais de um produto ou da embalagem, que identificam ou são fontes de significado da marca para os consumidores. É considerada propriedade intelectual e frequentemente é alvo de processos legais contra a sua falsificação (contrafação).
} 
(Figura 3.4). A Itaipava, da Cervejaria Petrópolis, utilizou um tom de vermelho similar em suas latinhas, também em 2010, e foi acusada pela Ambev de concorrência desleal. Após a disputa, a Itaipava reconquistou o direito do uso do vermelho em 2015, ao recorrer ao STJ. A decisão judicial estipulou que as cores das embalagens são elementos neutros no marketing das empresas e que a Ambev não detém o direito exclusivo de uso (Uol - Economia, 2015).

Figura 3.4: Latinhas das marcas de cerveja da (a) Ambev e da (b) Itaipava.

(a)

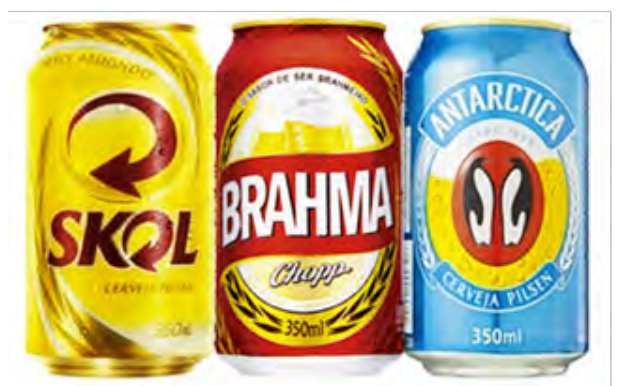

(b)

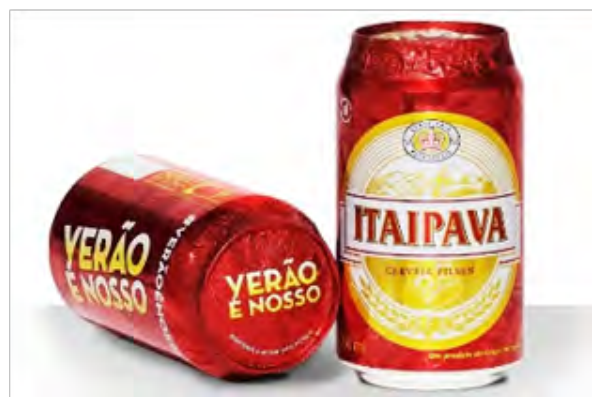

Fontes: (a) Loja virtual Pão-de-Açúcar (2017); (b) Reportagem da UOL (2015).

Um exemplo internacional é a Louboutin ${ }^{28}$, que aplica o vermelho nos solados dos sapatos desde 1992, e exigiu indenização de US\$ 1 milhão da Yves Saint Laurent, que o utilizou igualmente em suas criações (Figura 3.5). Ao final do processo, a decisão judicial agradou ambas as marcas: a Louboutin detém a exclusividade das solas vermelhas quando o sapato é de outra cor. Solas vermelhas em sapatos totalmente vermelhos, como os criados por YSL, não são considerados prática de contrafação (Daily Mail, 2012).

Figura 3.5: Escarpin da Louboutin e sandálias da YSL, coleção Tribute Patent Leather.

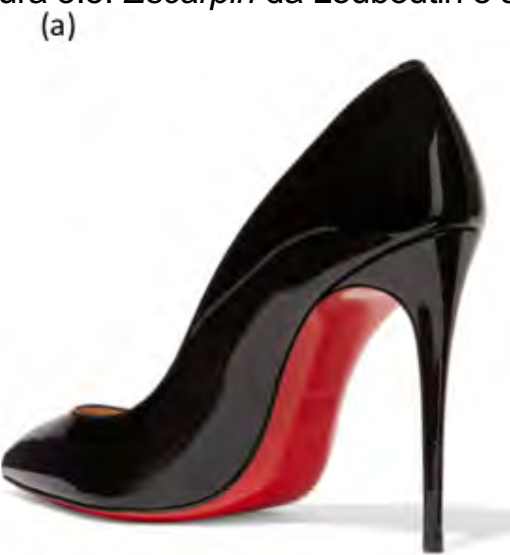

(b)
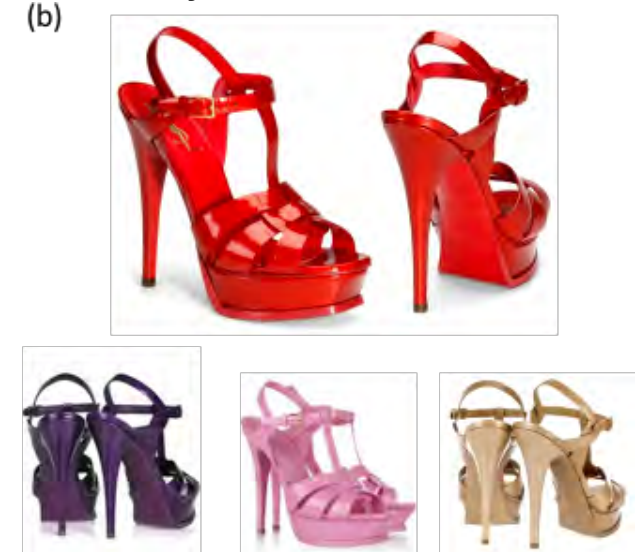

Fontes: (a) Site/loja da marca (Louboutin, 2017);(b) Loja Net-a-Porter (2017).

\footnotetext{
${ }^{28}$ O designer possui a patente, pois registrou o solado vermelho na França, em 2000, e nos EUA em 2008.
} 


\section{Depreciação: o excesso cromático que desvaloriza a marca}

A cor, em sua capacidade sígnica de delimitar o território marcário, informar as características e estipular a identidade de marca, é amplamente utilizada e valorizada por gestores e comunicadores. Porém, um desafio é encontrar o ponto ótimo do uso consistente, sem provocar respostas negativas por uma eventual hiperexposição: passar desapercebida (não informar), desvalorizá-la ou provocar um afastamento de seus públicos.

A última vez que eu fui visitar o Facebook na Califórnia. Em frente ao prédio há um enorme sinal de "like". Quando você entra lá, você sabe que está no Facebook. Eles não colocam o logo em todo o lugar .... Se você usar muito sua cor, ou seu nome, seu logotipo, em todos os lugares, irá desvalorizar a experiência. Em nossos escritórios nem tudo é roxo, não queremos queimar as pessoas com a cor. $A$ experiência no nosso site..., nas propagandas, nós usamos fortemente o roxo. Mas em um lugar onde as pessoas têm que estar o tempo todo, você pode saturar, ... elas começariam a se cansar do roxo se ele estivesse no banheiro, nas paredes do escritório, na cozinha. (Depoimento de especialista - Purple)

O McDonald's é uma marca colorida e há uma diferença entre como você usa cores na marca e quais são as cores da marca. Minha crença pessoal é: o amarelo e o vermelho, a cor secundária, devem ser usados como cores de assinatura... como antigamente, quando a pessoa escrevia uma carta e assinava seu nome no final.... O que acontece, na boa intenção, é que as pessoas de marketing tendem a abusar das cores da marca. E essas cores são tão poderosas, que podem dominar. $\cdots$

Nas lojas da Target, você vê uma superabundância de vermelho em tudo, dos carrinhos de compras até a sinalização e os uniformes dos funcionários... está em toda parte. Ao invés de usar como uma assinatura, eles usam a cor da marca permeando toda a experiência. Eles devem ter uma boa razão para fazer isso, mas eu acho um exagero. Eu fui lá, andei nas lojas, olhei o uso do logotipo e das cores, acho que é um sinal de uma marca insegura. Pense nisso: você vai à Target, você sabe que está na Target, você decidiu comprar algo na Target. Com que frequência preciso lembrar que você está na Target? (Depoimento de especialista - McDonald's)

Ao longo do tempo, o uso fixo das cores - que possibilita a identificação marcária pode levar à saturação, a uma percepção de rigidez, degaste ou envelhecimento. A marca é obrigada a evoluir e se reposicionar constantemente, refletindo as mudanças sociais e 
tecnológicas, atendendo novas expectativas, necessidades e desejos dos sujeitos consumidores. O dilema entre se diversificar ou manter as características de reconhecimento, pode ser enfrentado por ações de comunicação que equilibrem o oscilar contínuo entre extremos: a monotonia da repetição e a desqualificação da diversidade (Kapferer, 2012, pp. 271-273).

O uso da cor com coerência criativa, aptidão peculiar dos profissionais da comunicação visual e do design, pode ajudar nesse enfrentamento: compondo novas cores e combinações cromáticas, criando surpresas e renovações visuais, quando pertinente. $\mathrm{O}$ uso estratégico da cor vai além da expressão dos valores marcários essenciais (atendendo os anseios corporativos): valores que também façam sentido na e para a vida dos indivíduos-consumidores.

QUESTÃO 7 DA TESE:

\subsection{Por que e como a cor é usada para induzir um status preferencial pela marca?}

Utilizar um signo com o objetivo primordial de causar uma avaliação positiva ou negativa, ou seja, provocar uma resposta preferencial a certos objetos, julgamentos, necessidades, é usar esse signo na função avaliativa (Morris, 1946, p. 99). O uso avaliativo é mais efetivo por meio de signos que operam no modo apreciativo (ver seção 0), embora signos em outros modos também possam ser utilizados para avaliar adequadamente (Morris, 1946, p. 100). Aplicando o uso avaliativo para cores e marcas, tem-se a seguinte proposição:

\section{Proposição 7: o adequado uso avaliativo da cor promove a preferência pela marca}

O uso avaliativo da cor (ou de uma combinação de cores), promove avaliações, positivas ou negativas, de uma marca junto a seus públicos. O uso avaliativo é eficaz (avaliativamente adequado) quando as cores induzem os públicos à preferência pela marca - independentemente dessa marca ser a melhor para eles.

A eficácia de um signo em avaliar o objeto referente varia conforme circunstâncias individuais e sociais, e normalmente depende da função informativa ser bem sucedida (Morris, 1946, p. 101). Seguindo a ideia de Morris, para uma cor ser eficaz na promoção da preferência marcária, o mais adequado seria também informar os públicos, sobre a marca. Afinal, do que adiantaria gerar respostas positivas se o consumidor não sabe a qual marca associar os sentimentos positivos evocados? 
No intuito de gerar avaliações positivas para si, a marca pode explorar a capacidade sígnica da cor por duas maneiras: vinculando-se a cores que carregam associações positivas relevantes em seu contexto, ou criando novas associações entre ela (marca), cores e conceitos socialmente avaliados como positivos. Em ambos os casos, ao estabelecer equivalência simbólica com valores culturais apreciados, a marca pode se conectar emocionalmente com os indivíduos desejosos desses significados para si, a fim de construírem e legitimarem aspectos de seu mundo, sua família e seu ser (McCracken, 1993, pp. 129-130).

A tática mais comum, rápida e menos custosa, é utilizar uma carga sígnica estabelecida, pois aproveita interpretantes já instituídos. Porém, a associação é provavelmente também explorada por outras marcas, concorrentes ou de outras categorias, o que diminui a diferenciação marcária. Dois exemplos são o uso do rosa e do verde por marcas do mainstream, designando os mesmos conceitos, respectivamente: feminilidade e naturalidade.

A cor rosa é reiteradamente usada para identificar marcas, produtos e serviços para mulheres e crianças do sexo feminino (uso informativo) e para conquistar a preferência desse público alvo (uso avaliativo). Porém, nada comprova qualquer raiz fisiológica para a preferência de meninas por rosa e de meninos por azul (Figura 3.6): são aprendizados culturais (Hancock, 2014). Com esse uso repetido e apoiado por discursos verbais, foi formada uma associação generalizada do rosa com o conceito de feminilidade e correlatas estereotipagens (delicadeza, infantilidade, artificialidade e vaidade). Atualmente, os grupos minoritários, como o LGBT e o pós-feminista, reivindicam a cor na versão saturada, rosa-choque, para expressar empoderamento, diversão, sexualidade e luxúria (Koller, 2008).

Figura 3.6: Menino e menina com seus brinquedos e roupas, rosas e azuis.
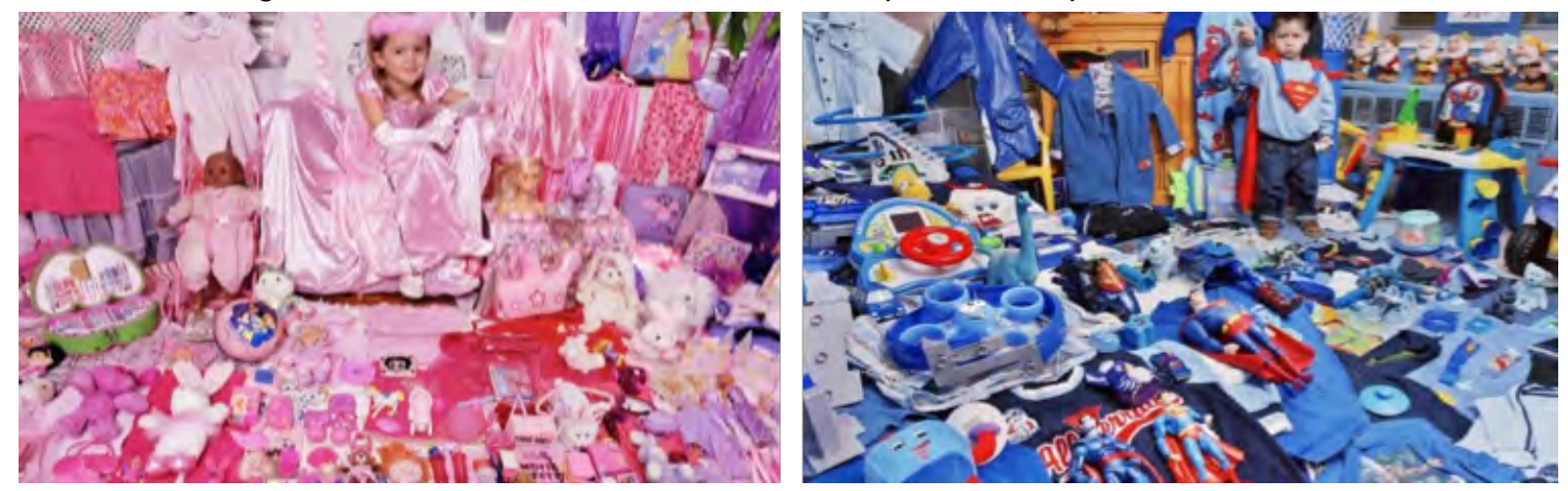

Fonte: Jeongmee Yong, para a Getty Images (Hancock, 2014).

Por sua vez, o verde é predominantemente utilizado para obter preferência através das associações com sustentabilidade (ecologia, responsabilidade ambiental, amiga-da-natureza) e 
saudabilidade (produtos orgânicos, livre-de-agrotóxicos, agricultura sustentável) (Schuldt, 2013; Singh, 2006; Sundar et al., 2017).

Um exemplo recente de uso avaliativo da cor, pautado sob os conceitos de fluidez e impermanência da contemporaneidade, é a utilização de uma paleta cromática ampla e variável como designadora marcária, configurando as marcas mutantes na cor. Essas marcas abrem mão do uso informativo (identificação da marca) pelo avaliativo, a fim de evocar conceitos de movimento, inovação, diversidade, criatividade, além do intuito de agradar, de ser relevante para mais pessoas, em suas variadas preferências cromáticas.

Eu vejo as mudanças como movimentos estratégicos intencionais.... Quando você tem uma marca que trata da geração jovem, por definição é: 'minha geração não quer estar conectada à mais velha'. Meus filhos de 12 e 13 anos, não querem estar conectados à minha geração, eu sou velho. Se você quiser apresentar sua marca como a escolha da nova geração, você deve continuamente renová-la. (Depoimento de especialista - McDonald's)

Não fazemos pesquisa com clientes, mas pegamos as ideias dos revendedores e o que está vendendo nas regiões... Sempre oferecermos uma coleção de aproximadamente 10 cores.... Fazemos uma coleção ampla, para atrair uma grande variedade de pessoas. Dessa coleção, qualquer consumidor vai encontrar algo que gosta, que ecoa com ele. Eles terão uma primeira opção, uma segunda, e se eles estão comprando um veículo familiar, o marido e a esposa podem ter diferentes pontos-de-vista, e eles terão que fazer um acordo sobre qual será a cor. É interessante. (Depoimento de especialista - Ford Motor Company)

Além de ser uma prática frequente pelas marcas de produtos, a variação cromática é feita também por marcas de serviço. Por exemplo, pelas marcas mutantes em cor da Vivo e Oi, que se posicionam sob os conceitos de dinamismo, tecnologia em constante evolução, amplitude de ofertas, liberdade de expressão (Sato, 2016).

\section{Originalidade: para marcas únicas, associações cromáticas únicas}

A natureza múltipla e variável do signo-cor possibilita as marcas a criarem associações inéditas entre cor e valores culturais, no intuito de causar avaliações positivas em seus públicos. Apesar de ser uma tática mais lenta e onerosa do que o aproveitamento de 
interpretantes cromáticos já estabelecidos, ao estabelecerem novas associações, as marcas fortalecem sua diferenciação, sua percepção de originalidade.

Esse é o caso do Itaú, que escolheu a cor laranja não previamente associada com serviços financeiros, dinheiro ou riqueza. Outro caso é a marca Tiffany, com o azul-esverdeado (Figura 3.7). Ao selecionar, em 1845, seu hoje icônico e patenteado "Tiffany Blue" para ser a cor da capa de um catálogo, a empresa não seguia nenhuma convenção simbólica préestabelecida: a escolha da cor se deu provavelmente pela popularidade da pedra turquesa na joalheria do século XIX (Tiffany \& Co., 2016).

Figura 3.7: Desde 1845, a Tiffany utiliza seu azul para construir associações entre a cor e amor, casamento, sofisticação, conceitos positivos no contexto da marca.

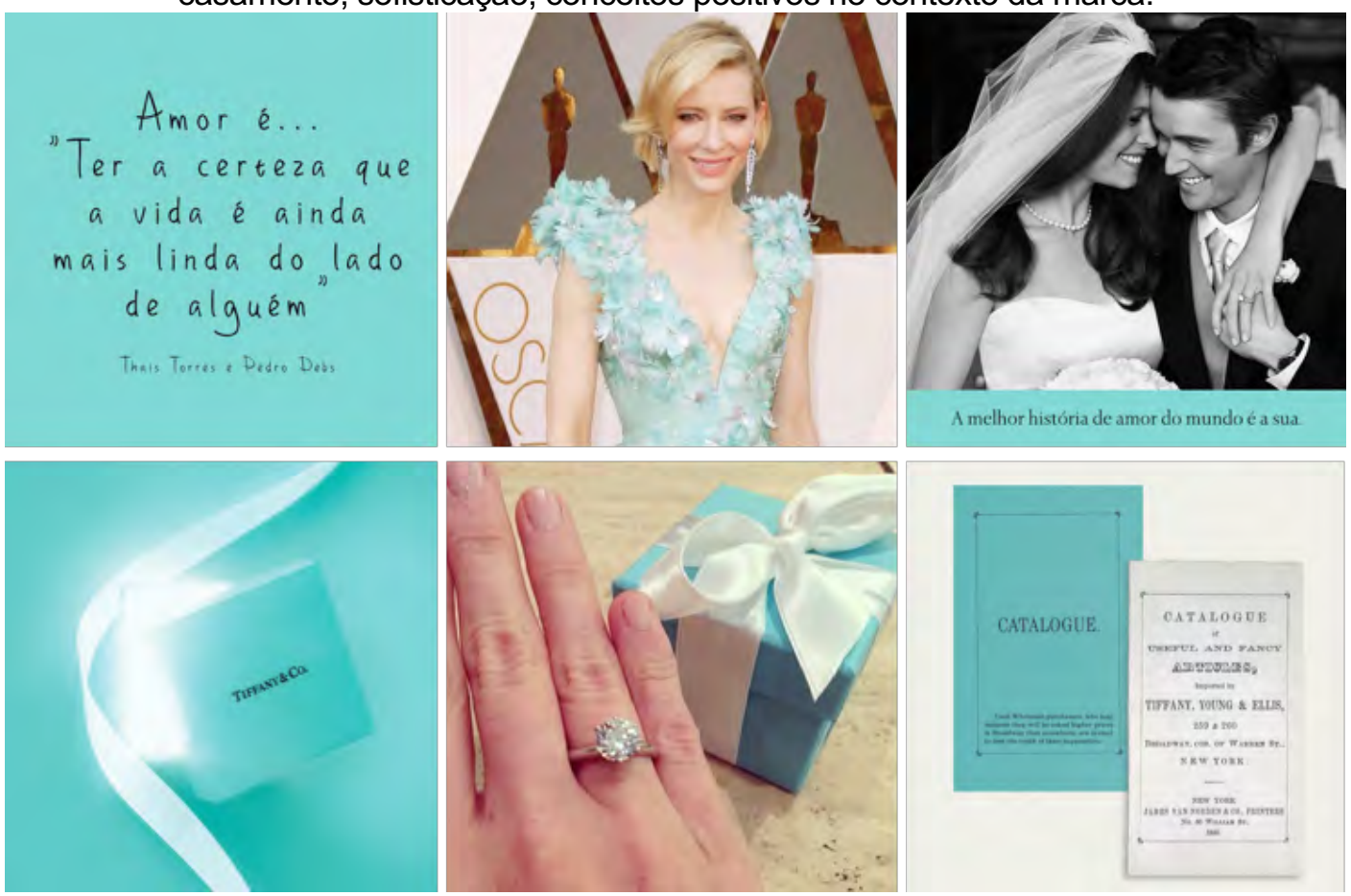

Fonte: Mosaico criado pela autora, com imagens postadas entre 2012 e 2017, no perfil oficial da Tiffany Brasil, no Facebook. Último acesso em15/10/2017.

De maneira similar, o McDonald's utiliza a cor marrom como signo designador para o McCafé desde seu lançamento, em 1993. Nas comunicações e ativações da marca, o marrom é pareado com os conceitos de sustentabilidade e de qualidade superior. Assim, o McDonald's carrega a cor com valores positivos, indo além da designação cromática do produto principal. Conforme revela o depoimento do colaborador, a associação é indireta - sabe-se que sustentabilidade é comumente ligada com o verde - mas realça sinestesicamente a cor/sabor do ingrediente central, e traz distinção preferencial para a marca: 
Outra cor importante para a marca é o marrom, que está conectado ao McCafé ... O marrom foi selecionado pela associação com a experiência do café. E por causa dos esforços de sustentabilidade que a empresa faz em termos de abastecimento socialmente responsável dos grãos-de-café, há um grande benefício [para a marca] em conectar o marrom com sustentabilidade. É uma mensagem muito indireta, mas é a intenção, de qualquer forma. ...

O marrom e o branco foram selecionados intencionalmente por causa das credenciais do café, para ser sofisticado, e com conotação muito mais natural. Na medida que o McCafé se expandiu para o mundo todo, assumiu uma variedade de manifestações diferentes, mas o marrom e o branco continuam a ser a maior faceta da submarca McCafé. (Depoimento de especialista - McDonald's)

No setor esportivo, a Nike criou uma associação original e exclusiva entre um tom verde-amarelo "elétrico" (Figura 3.8) e os conceitos de atletismo e desempenho superior. Para o lançamento da cor, nas Olímpiadas de Londres de 2012 (evento que a Nike não patrocinou) a estratégia foi entregar a 400 atletas, pares de tênis na cor "volt" (e não nas cores das delegações nacionais), diferente de qualquer cor usada nas arenas esportivas (Williams, 2015, pp. 57-58).

Figura 3.8: A volt (a) nos pés do vencedor e finalistas (b) dos 5mil metros em Londres, 2012. (a)

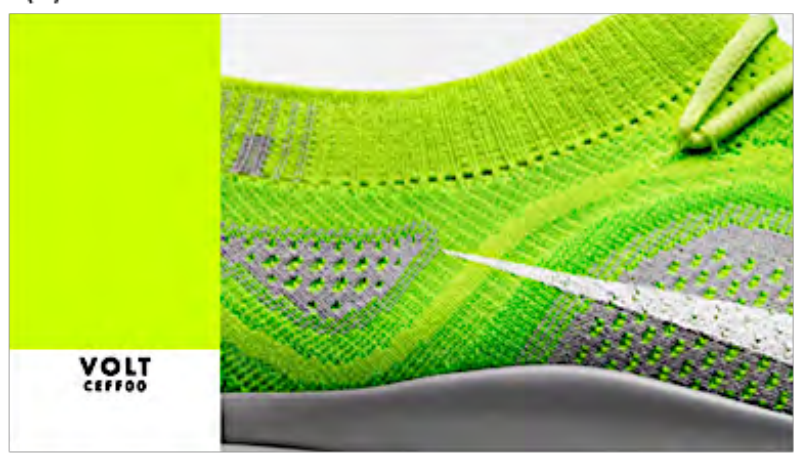

(b)

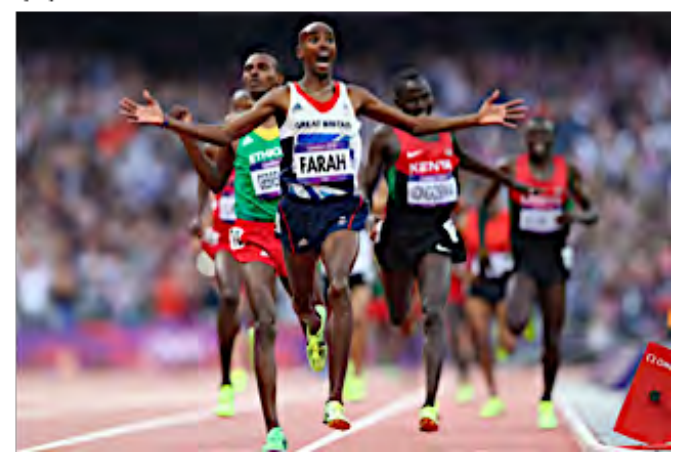

Fontes: (a) Complex Media (Golliff, 2013); (b) Daily Mail (P. Collins, 2012).

Veja a Nike... ao longo dos anos, eles criaram uma cor, que descrevem como "Volt". No marketing esportivo, um atleta Nike normalmente está usando essa cor, para que as pessoas saibam que o atleta é conectado com a marca. Nenhuma outra empresa realmente pode usar essa cor em uma perspectiva própria.... A Nike está começando a criar um sentimento de 'atletismo', um produto na cor volt é percebido mais como "atlético" do que como "estilo-de-vida". Você normalmente não vê [produtos] 'estilo-de-vida' nesse verde claro. 


\section{Quando eu trabalhava para a Adidas nós fizemos a mesma coisa, no mesmo momento..., mas nunca chegou a estourar no mercado. Tipicamente uma nova cor é lançada durante as Olimpíadas... lá, o que você encontrar nas sapatilhas de corrida, vai estourar durante todo o ano em uniformes e acessórios esportivos. (Depoimento de especialista - New Balance)}

Do mesmo modo que a marca pode criar associações entre ela, uma cor e conceitos positivamente avaliados, ela pode propositadamente gerar associações negativas entre cores e valores, a fim de infamar a imagem dos concorrentes. Um exemplo é a disputa entre a Gol e a Azul Linhas Aéreas (Figura 3.9).

Figura 3.9: Anúncio digital da Gol e anúncio impresso da Azul, provocando-se mutualmente.
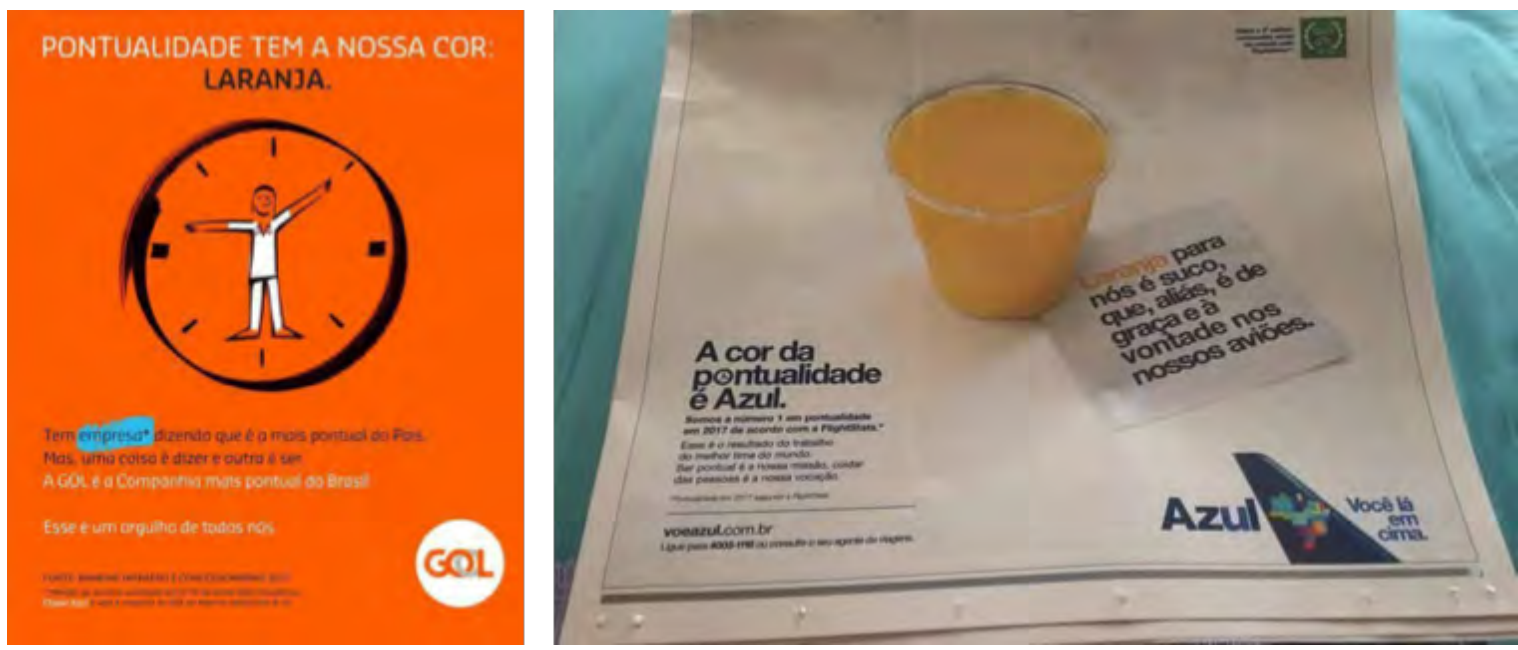

Fonte: perfil do Facebook da JN viagens e Turismo, postagem de 12/10/2017. Último acesso em 09/11/2017.

A Azul comemorou ser a empresa mais pontual de 2017, segundo o ranking FlighStats de 2017, e provocou a Gol com um escárnio à cor laranja identificadora: “A cor da pontualidade é Azul. Laranja para nós é suco que, aliás, é de graça e à vontade nos nossos aviões". A Gol respondeu, ao vencer como a mais pontual, segundo o ranking da Infraero de 2017, referindo-se à concorrente apenas com um destaque na palavra "empresa" por meio da cor azul: "Tem empresa dizendo que é a mais pontual do país. Mas, uma coisa é dizer, a outra é ser. A Gol é a Companhia mais pontual do Brasil”.

Apesar de chamarem a atenção, estudos demostram que propagandas exibindo aspectos negativos ou difamatórios sobre os concorrentes (Jain \& Posavac, 2004), podem provocar desconfiança sobre sinceridade do anunciante e, por consequência, gerar avaliações menos positivas para ele. Assim, ao difamar as competidoras por meio da cor, uma marca pode evocar, em seus públicos, avaliações negativas, o oposto do planejado. 


\section{Relevância: cores para avaliar positivamente, no aqui e agora}

São cada vez mais comuns os casos de marcas que adotam, temporariamente ou regionalmente, cores outras que as designadoras originais, a fim de serem mais estimadas e relevantes pelo público. Essa tática de uso avaliativo implica em abrir mão do uso identificativo da cor, para efetivar uma transferência de significados positivos, do mundo culturalmente constituído para a marca (McCracken, 1986), em um período ou local específico. Fora da temporada ou da região geográfica em questão, a marca mantém suas cores identificadoras.

Um exemplo, de abrangência mundial, foi a alteração das cores de logotipos na ocasião da legalização do casamento homoafetivo pela Suprema Corte dos Estados Unidos para todo o território norte-americano (em 26 de junho de 2015). Na data, diversas pessoas e marcas coloriram suas imagens de perfil das redes sociais (Figura 3.10) com o arco-íris símbolo do movimento LGBT. Ao se mostrarem a favor, e mais do que isso, celebrarem a conquista, reforçaram seus valores e crenças e conquistaram aprovação e relevância social.

Figura 3.10: Exemplos de logotipos alterados na cor (a) no Twitter e (b) no Facebook.

(a)

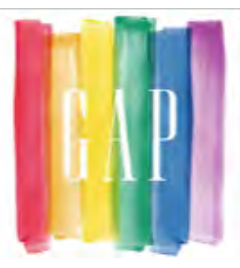

Fontes: Perfis oficiais das marcas no Facebook (
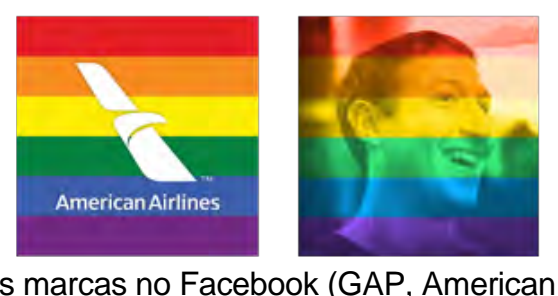
(b)
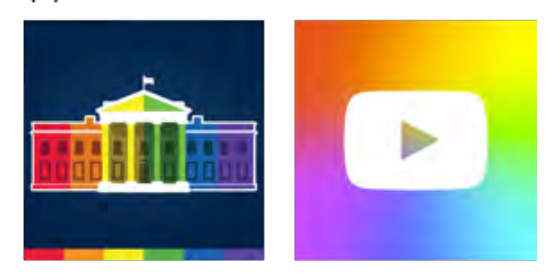

House e YouTube. Último acesso em 27/06/2015.

Apesar de fortalecerem a conexão emocional com seus públicos, as marcas correm o risco de confundi-los, ao abrirem mão de suas cores identificadoras. Isso se dá porque a nova cor (ou cores) que manifesta visualmente a marca opera no modo transformativo (ver seção 2.5), e altera as significações designativas e apreciativas instauradas. Novamente, o equilíbrio entre consistência e inovação na cor é questão fundamental na criação de ações promocionais de marca.

\section{Desconfiança e rejeição: o uso hipócrita das cores}

Da mesma forma que a cor pode ser utilizada para informar erroneamente, a cor também é explorada para provocar preferências "falsas” nos indivíduos, propositadamente. Seja explorando associações cromáticas já formadas, seja criando associações originais, ou vinculando-se temporariamente/regionalmente a cores e conceitos inusuais, uma marca pode associar-se a valores que não fazem, de fato, parte de suas políticas e práticas, verdadeiramente. 
O caso mais conhecido é o greenwashing ("banho-de-verde"), o "uso cínico de temas ambientais para reduzir a percepção do mau comportamento corporativo" (Greenpeace 2008).

Por exemplo, a Coca-Cola é acusada de greenwashing com a submarca Coca-Cola Life, recentemente reposicionada como Coca-Cola adoçada com estévia. Apesar de conter menos calorias do que a Coca-Cola normal, a versão é um refrigerante sem valor nutricional e que contém, em uma única latinha, a dose diária total de açúcar recomendada para um adulto não é de fato um produto saudável (Dean 2015).

Estudos indicam que os indivíduos desconfiam ou possuem uma atitude negativa em relação às empresas que afirmam ser ecologicamente responsáveis, e recomendam o menor uso dos signos verdes, verbais ou visuais, para reconstruírem a confiança e a atitude positiva dos consumidores em relação a esses signos (Chen \& Chang, 2013). Pesquisadores do Direito procuram meios legais para policiar e impedir "fraudes de responsabilidade social corporativa" a consumidores e investidores (Cherry \& Sneirson, 2011). Nos Estados Unidos, a Organização para Patentes e Registros (UPSTO) criou regras para evitar o uso da palavra "verde", mas não proibiu aplicação da cor no branding visual (Sundar \& Kellaris, 2016).

Um dos casos mais polêmicos é o da empresa global de energia, British Petroleum (BP): em 2010, a explosão da plataforma Deepwater Horizon de perfuração petrolífera no Golfo do México, causou um derramamento de óleo considerado o maior desastre ambiental da história dos Estados Unidos. O acidente acorreu dois meses após o rebranding da marca (Figura 3.11a) para beyond petroleum (além de petróleo), reposicionamento realizado para evocar a percepção de respeito ambiental e de inovação tecnológica (Landor, 2010).

Figura 3.11: (a) Logotipo da BP e (b) sátiras visuais feitas após o vazamento de óleo.
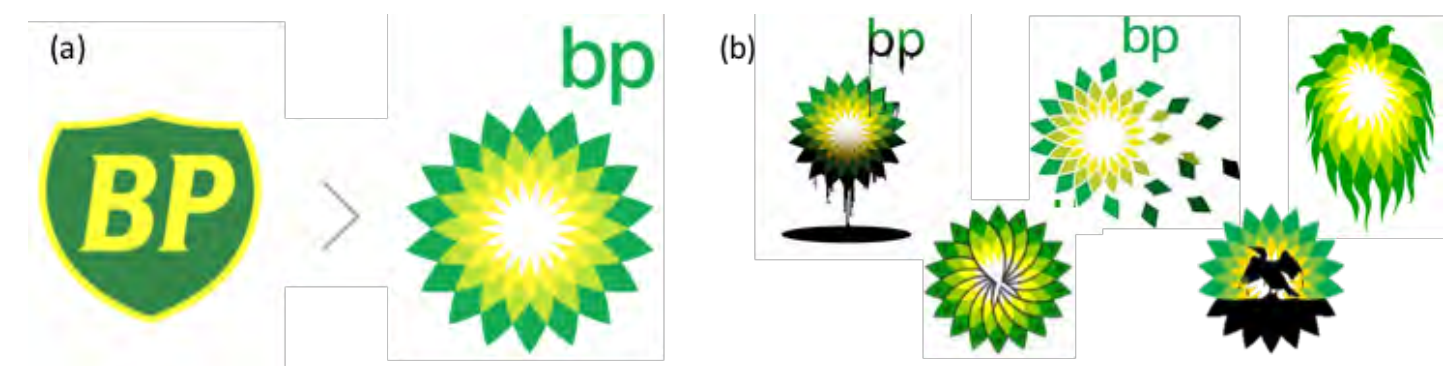

Fontes: (a) Site da Landor (2010); (b) Busca por "BP logo" no Google Images. Último acesso em 8/11/2017.

O logotipo, já em verde e amarelo desde 1947, foi redesenhado como um sol radiante, remetendo também a uma flor ou uma hélice de uma turbina eólica (geradora de energia limpa, que a BP oferece em muito menor escala que a derivada de petróleo). A 
discrepância entre o novo posicionamento e os negócios da marca, evidenciados com o acidente, gerou inúmeras manifestações contra a corporação. Sete anos depois, ainda é possível visualizar versões de logotipos satirizados, feitos por críticos do mundo todo em resposta ao acidente e ao greenwashing da BP (Figura 3.11b).

A utilização avaliativa da cor rosa também é alvo de críticas, quando não transmite autenticidade. O termo pinkwashing foi cunhado para descrever a conduta de empresas que comunicam financiar pesquisas para eliminar o câncer de mama - com a cor ou a fitinha rosa típica da campanha (Figura 3.12) - ao mesmo tempo que vendem produtos suspeitos de contribuírem para adoecimento de câncer (Alhouti, Johnson, \& Holloway, 2016).

Figura 3.12: $(a, b)$ KFC e Campbell's usam a cor rosa para comunicar apoio à luta contra o câncer de mama; (c, d) Reações negativas da sociedade contra o pinkwashing.

(a)

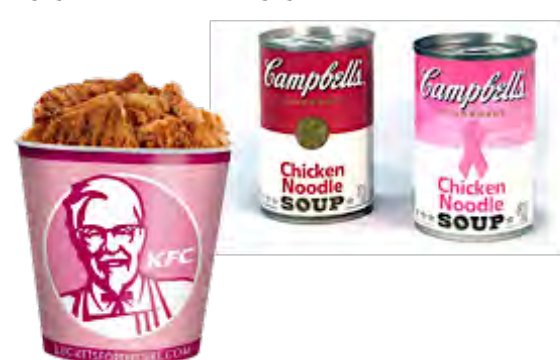

(c)

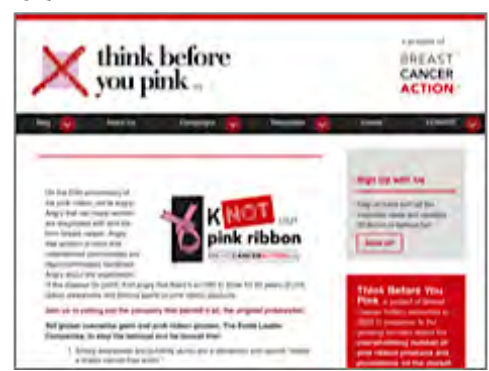

(d)

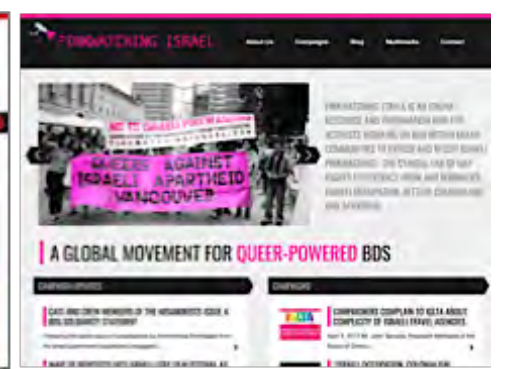

Fontes: (a, b) The Guardian (2012); (c) Breast Cancer Action (2017) (d) Pinkwatching Israel (2010).

Esse foi o caso da marca KFC, promocionando a galinha frita com um balde cor-derosa, e da sopa Campbell's, alterando as latas de vermelho para rosa. A ONG beneficiada, Susan G. Komen ${ }^{29}$, declara que o apoio de grandes marcas é importante pelo dinheiro e conhecimento que gera à causa (Susan G. Komen for the Cure, 2017).

Por outro lado, essas campanhas são criticadas e acusadas de hipócritas e interesseiras, por indivíduos e instituições que se organizam para combater o pinkwashing (Breast Cancer Action, 2017; Hutchison, 2010). Além de contraditórias, o uso estereotipado do rosa-bebê infantiliza a imagem das mulheres que vivem com câncer de mama, sugerindo que elas sejam imaturas, passivas, suaves e dependentes, diferentemente do vermelho das campanhas do HIV/AIDS, que evoca a diligência e a raiva em relação à falta de investimentos em pesquisa por parte dos governos (Decker \& Elliott, 2011, pp. 264-265).

\footnotetext{
${ }^{29}$ O centro Susan G. Komen for the Cure, usa desde a sua fundação, em 1982, a cor rosa para se identificar e gerar conhecimento para a luta contra o câncer. As fitinhas rosas começaram a ser distribuídas em 1991, em um evento esportivo promocional (Susan G. Komen for the Cure, 2017).
} 
As ações mercadológicas relacionadas a causas (cause related marketing - CRM) trazem avaliações positivas de autenticidade para a marca, quando são percebidas coerentes com o negócio e pensadas para o médio e longo prazos. Do contrário, podem gerar suspeitas e avaliações negativas de egoísmo e oportunismo (Ellen, Webb, \& Mohr, 2006). Similarmente, ao suspeitarem das intenções das campanhas que usam bebês, filhotes de animais ou modelos de beleza (celebridades) para conquistar interesse e apreciação, os consumidores resistem às mensagens publicitárias e o resultado pode ser o contrário do intencionado: avaliações negativas em relação ao anunciante (M. C. Campbell, 1995).

\section{QUESTÃO 8 DA TESE:}

\subsection{Por que e como a cor é usada para incitar ações para a marca?}

De acordo com Morris (1946, p. 102), os signos produzidos com a função principal de determinar como o intérprete deve agir em direção a algo, são signos usados na função incitiva. Essa função é geralmente melhor sucedida quando realizada por signos operando no modo prescritivo (ver seção 0), uma vez que esses signos dispõem os intérpretes à ação. Porém, um signo pode ser usado com a intenção de persuadir quando ele opera em diferentes modos, por exemplo: ao designar as consequências de algo (modo designativo) ou enaltecer as vantagens ou desvantagens (modo apreciativo) desse algo.

A capacidade de persuasão de um signo (adequação incitiva) está frequentemente, não obrigatoriamente, relacionada com as prévias adequações de informar convincentemente e avaliar eficazmente. Além disso, a relação entre o produtor do signo e o intérprete é altamente relevante no processo persuasivo: a mãe pode dominar o comportamento de uma criança com um signo de comando que não teria efeito algum em um adulto (Morris, 1946, p. 103).

Aplicando o uso incitivo para a marca e o signo-cor, tem-se a seguinte proposição:

\section{Proposição 8: o adequado uso incitivo da cor provoca o engajamento de marca}

O uso incitivo da cor (ou de uma combinação de cores) instiga os públicos de uma marca a agirem em relação a ela. $\mathbf{O}$ uso incitivo é persuasivo (incitivamente adequado) quando os públicos se engajam em ações almejadas pela marca independentemente dessa ação ser adequada para o intérprete atuante. 
A noção de "engajamento" considerada aqui, corresponde às manifestações comportamentais do consumidor em direção a uma marca, causadas por diferentes fatores motivacionais (van Doorn et al., 2010). As marcas, cientes da influência das cores no comportamento humano (modo prescritivo de significação), usam as cores estrategicamente para gerar experimentação e compra, para gerar boca-a-boca, postagens, etc.

Nós temos estratégias com nossos varejistas e parceiros.... Quando acreditamos que um sapato será bem-sucedido em vendas, $o$ colocamos cercado por outras cores, não as que o consumidor compra em primeiro lugar, mas que o atrai para o modelo. Por exemplo, modelos em preto-branco ou preto-prata, são tipicamente os mais comprados... e os colocamos ao lado de uma cor brilhante, da cor da moda, ou de um vermelho ou azul. Os consumidores experimentam o par na cor vermelha, mas geralmente compram o preto. Então, usamos uma cor para atrair consumidores, mas sabemos que eles não comprarão tantos pares naquela cor. ...

Fazemos isso com histórico e informação. Produzimos o montante certo que venderá. Há muitas pessoas que compram em cores diferentes, mas sabemos a porcentagem: $60 \%$ de todos os modelos são feitos em preto. (Depoimento de especialista - New Balance)

Aqui estão meus azuis tons de praia, com meus tons de cinza arenoso, para dar esse aspecto de beira-mar. Eles combinam, mas não só por isso, eles vão super bem com as cores de cima, não brigam.... Eu quero que as pessoas digam "Uau, olha essa loja"... e então "oh, essa cor também vai bem com essa". Então eles já pegam um conjunto, um múltiplo, e não apenas um item. (Depoimento de especialista - Glassybaby).

Ao se engajarem em comportamentos relacionados a marcas, os indivíduos participam das principais manifestações ritualísticas da vida social contemporânea (Sherry, 2005, p. 44). Muito além do ato de comprar, o consumir engloba uma série de práticas pelas quais os indivíduos podem tomar para si as propriedades significativas localizadas nos bens (McCracken, 1986). Em uma breve listagem não exaustiva, as marcas podem usar persuasivamente as cores para provocar expressões comportamentais diretamente ligadas, ou não, a transações financeiras, como os seguintes rituais:

- Troca: incitar um indivíduo a presentear (ou presentear-se) com produtos e serviços, por causa de uma cor (ou combinação de cores) específica;

- Posse: gerar discussão, recomendação, comparação, customização, exibição/ 
postagem (das posses ou de fotos e vídeos do produto ou serviço), compra e recompra, por causa de uma cor (ou combinação de cores) específica;

- Arrumação: promover cuidados pessoais ou arrumações e consertos das posses, como limpar, pintar, organizar, por meio e em função das cores;

- Desapropriação/reapropriação: ensinar e incentivar a renovação, reciclagem, não descarte ou colecionismo, por meio e em função das cores.

A fim de maximizar o uso incitivo da cor, a marca pode explorar a capacidade apreciativa do signo-cor em provocar os indivíduos a respostas positivas. Quanto mais preferida a cor, mais provavelmente uma marca (ou produto, ou serviço) nessa cor será comentada, postada, fotografada, comprada, recomprada, usada, presenteada, etc. Neste aspecto, uma estratégia cromática persuasiva é oferecer uma ampla variedade de cores e combinações cromáticas, a fim de atingir mais e variados públicos.

\section{Versatilidade: variedade de cores, tudo para todos}

Os indivíduos gostam e tendem a procurar variedade de produtos e serviços que consomem, por distintas razões: pelo desejo dos estímulos que vêm com uma nova experiência; por estarem saciados (fartos) dos atributos da opção já experimentada; e para ajudar nas incertezas futuras - eventuais mudanças nas preferências ou dilemas de escolha entre muitas opções (Kahn \& Ratner, 2005, p. 106). Em relação à oferta de cores pelas marcas, é possível dizer que, quanto mais opções de cores, maior a potencialidade da marca em incitar diferentes públicos a se engajarem positivamente com ela. Cientes disso, as marcas criam e comunicam a diversidade e a versatilidade cromática.

A busca por variedade no consumo de marcas se dá principalmente em compras na categoria de produtos hedônicos e na categoria de baixo risco percebido - pouco envolvimento, compra frequente e pouco determinada por preferência, e pouca diferenciação percebida entre as marcas disponíveis (Trijp, Hoyer, \& Inman, 1996). Esta tese especula que, ao oferecer várias opções de cores em seus produtos e serviços, uma marca pode propiciar ao consumidor a experiência de busca e posse de variedade, incentivando-o a comprar mais e desmotivando-o a migrar para as concorrentes.

Porém, esse aumento na quantidade consumida é influenciado pela percepção de maior variedade: não é apenas oferecer mais opções, mas fazer com que o consumidor perceba que existe mais variedade. Isso pode ser alcançado ao se organizar (e.g. separar) as opções ou diferenciá-las explicitamente (Kahn \& Wansink, 2004). Assim, criar cores nitidamente distintas 
entre si (no matiz, brilho e/ou saturação) e arrumar as ofertas por cores (ver seção 3.4 sobre uso sistêmico da cor), pode provocar mais engajamento dos indivíduos, com as marcas.

Por exemplo, a marca Glassybaby de copos artesanais, explora as inúmeras combinações cromáticas possíveis nos seus espaços de venda e nas redes sociais (Figura 3.13), como apelo de engajamento para diferentes públicos e em diferentes ocasiões promocionais:

\begin{abstract}
Eu mudo o layout o tempo todo, para renovar. Você deve sempre visualmente mudar, ou as pessoas não entrarão [na loja].... Eu mudo o lugar na prateleira a cada dois meses... essas cores irão para o topo, esse conjunto vem pra baixo, e esse vai para a prateleira do meio. (Depoimento de especialista - Glassybaby)
\end{abstract}

Figura 3.13: Postagens de um vitrinista/vendedor da Glassybaby, exibindo (a) variedade de cores; (b) (a) uma consumidora que encontrou sua cor preferida; (c) um arranjo cromático especial de Natal.
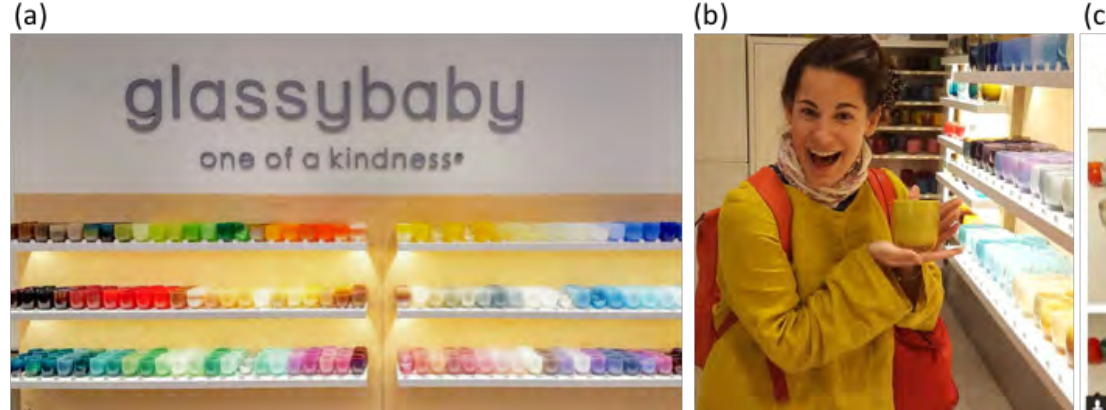

(c)

Fonte: Instagram do vitrinista/vendedor da Glassybaby. Último acesso em 30/12/2017.

Porém, estudos da psicologia do consumo discutem a complexidade do ato de escolher e o quanto ele depende do contexto social, indicando que nem sempre ofertar um número elevado de opções provoca emoções ou ações positivas nos indivíduos. Por exemplo, na sociedade ocidental, onde prevalece o modelo de self independente (baseado na autoexpressão e no individualismo), o indivíduo tende a escolher o que é único e diferente, exercitando sua autonomia e singularidade. Diferentemente, no modelo de self interdependente da sociedade oriental (baseado em valores de reciprocidade e obrigações sociais), a escolha pessoal leva em conta a preferência do grupo, expressando sentimentos de pertencimento e conformidade (Iyengar \& Lepper, 1999; Kim \& Markus, 1999). Comparativamente, o segundo contexto de mercado demandaria menos variedade na oferta de cores do que o primeiro.

Mesmo em indivíduos da sociedade ocidental, onde o "escolher" é valorizado e fortemente ligado à ideia de democracia, liberdade e bem-estar, o excesso de opções de escolha (choice overload) frequentemente leva à paralisia (postergação da escolha), a más decisões de escolha ou à insatisfação - inclusive quando a escolha foi adequada (Markus \& Schwartz, 
2010). Aplicando a ideia para cores e marcas, não existe um número pré-determinado para a variedade cromática ideal, mas se sabe que existe um limite máximo e uma variedade ótima. Esses números de opções, o ótimo e o máximo, devem ser investigados e estipulados caso a caso, a depender da categoria, dos competidores, do contexto cultural, etc., não apenas para a viabilidade econômica do negócio, mas para se evitar a inadequação persuasiva.

\section{Normatização: cores prescritas e o consumo conspícuo}

Para obter o engajamento do consumidor nesse cenário múltiplo e mutante das preferências sazonais, ecléticas, individuais ou coletivas, as marcas têm apoiado as decisões sobre o uso das cores em estudos de tendências (color trends) e de sua previsão (color forecasting). Esse serviço de inteligência cromática é realizado por equipes internas (do setor de design, inovação, marketing, etc.), ou externas (por institutos de pesquisa, consultorias de análise de mercado e consumo, etc.). A missão principal dos especialistas é a de antecipar ou "caçar" gostos e comportamentos (coolhunting), captar e interpretar metodologicamente esses sintomas do "espírito do tempo" (zeitgeist) para que sejam explorados nas estratégias de marca (J. Santos, 2015; J. Santos \& Sato, 2009).

As empresas que nos procuram querem fazer dinheiro, querem saber se estão fazendo seus produtos na cor certa.... Eles querem dinheiro porque esse é o objetivo de todas as marcas, sem ele as marcas não existem. Agora temos Instagram, Snapchat, exposição pública... a publicidade não é apenas revista ou outdoor. É sobre como todos nós experimentamos as marcas enquanto compartilhamos nossas imagens uns com os outros. As marcas olham para isso e a cor é grande parte disso. (Depoimento de especialista - WGSN)

"Existe o que eu chamo de "cores tolas", feitas apenas para serem diferentes e não são relativas à época, ao tempo em que estão inseridas.... Não é uma questão de gosto pessoal, é preciso fazer muita pesquisa e olhar para as melhores práticas do segmento automotivo e fora dele. É preciso entender o que está acontecendo agora e no futuro próximo, para criar algo apropriado para a marca e seus produtos, considerando as tendências de cor que estão acontecendo ou que estão chegando. (Depoimento de especialista Ford Motor Company) 
A maior medida de sucesso é o quão bem você vende. Se o seu produto vende bem, então é uma combinação de muitas coisas que foram feitas certo. Em termos de medir o sucesso de uma cor vs. outra, muitas vezes classificamos, vemos quais cores atenderam nossas expectativas de venda, e se não, porque não.

...

Eu não acho que exista um modo errado de se usar cor... mas a marca tem que ter certeza de estar construindo sua variedade em consistência com o que os consumidores estão pedindo. Atualmente, não vamos ver cores fortes nos sapatos esportivos, mas 4 ou 5 anos atrás... havia o modelo Noosa, da Asics, com cerca de 30 cores em cada par, era a tendência. Se você vestir isso agora, vai parecer um sapato de palhaço... A marca tem que estar segura de sempre interagir com os consumidores... em algum ponto, o pêndulo do que está na moda hoje [cinzas e cores desaturadas] vai voltar a ser algo diferente. (Depoimento de especialista - New Balance)

As equipes especialistas definem quais e quantas cores uma marca vai usar durante cada temporada, em escopo global ou regional, para cada categoria em que atua. Geralmente, a paleta cromática prescrita inclui dois subgrupos: um perene, outro efêmero:

Nas criações sazonais, analisamos quantas opções terá um modelo, digamos que 4 ou 5 por modelo, em uma temporada. A equipe de cores nos pede um direcional sobre a cor de base.... Em seguida, eles trabalharão para colorir os sapatos adequadamente, em duas maneiras diferentes:

- Uma é cor constante, que é sempre preto \& branco ou preto \& prata, além das cores tradicionais de universidades, como o azul royal ou azul marinho, muito importante para os homens; - O outro é chamado de variáveis, as cores da moda: azuis claros, púrpuras, marrons, cor de chiclete...

Se nós vamos ter um modelo em 5 opções, podemos dizer que serão três em cor constante e duas em cor variável" (Depoimento de especialista - New Balance).

Nós mantemos nossas cores principais semelhantes, preto, prata, até vermelhos, nós mantemos global. Concebemos um espaço de cores estreito para as cores principais. E fazemos também o que chamamos de cores de tendência, cores do tipo regional, para a Austrália, para a América do Norte, Europa e China. (Depoimento de especialista - Ford Motor Company) 
Nós prevemos os grupos de cores com antecedência, o que chamamos cor global. A cor global tem 3 histórias, cada história com 10 cores. E a partir dessas 30 cores, escolheremos as 5 cores superiores, que podem ser rosa-milênio, laranja, um pouco de amarelo... as melhores cores para se investir. A partir daí nós adaptamos, com relatórios feitos por região, explicando como elas devem ser aplicadas na América Latina, nos EUA, na Europa. Porque cada região tem uma visão diferente da cor, também. (Depoimento de especialista - WGSN)

O uso adequadamente persuasivo das cores tem o poder de alterar a valência de apreciações cromáticas estipuladas anteriormente (gostar / não gostar) e a ordem clássica dos estágios de processamento de informação pelo consumidor (ver seção 2.6): primeiramente, reconhecer uma marca (com o apoio da cor), depois, gostar dessa marca ou do produto/serviço (graças a suas cores) e por fim, se engajar em uma ação em relação à marca, como pesquisar preços, experimentar, comprar e recomendar. Não raramente, normas ou convenções culturais, morais ou pessoais, fazem com que o indivíduo haja independentemente (e até contrariamente) das suas preferências (Amir, Lobel, \& Ariely, 2005, p. 90). Assim, ao estipular uma cor (ou combinação de cores) como a sendo a melhor ou mais apropriada, a marca pode provocar a compra ou outro comportamento, mesmo quando o consumidor não aprecia as cores prescritas.

Além disso, estudos mostraram que as pessoas temem ser avaliadas como entediantes e cabeças-estreitas, caso repitam constantemente suas escolhas. Por isso, quando o consumo é público (vs. privado) e hedônico (aperitivos, doces, músicas), os indivíduos experimentam mais variações, e não apenas o item favorito, a fim de se mostrarem mais criativos e interessantes (Ratner \& Kahn, 2002). Nesse aspecto, a marca que oferece cores inovadoras, da moda, leva o público a comprar por desejarem aprovação social.

A apreciação da cor da temporada pode acontecer após a compra provocada por essa mesma cor. Como já discutido, uma "nova cor" aplicada à paleta cromática tem a capacidade sígnica de alterar as respostas pré-estabelecidas na mente do intérprete-consumidor, operando no modo transformativo de significação (seção 2.5). Assim, cores até então mal avaliadas, com a posse, exibição ou outros rituais, passam a ser apreciadas, seja por motivações intrínsecas (e.g. cansou das cores de sempre) ou extrínsecas (o seu ator preferido usa a cor, todo mundo está falando/postando positivamente, etc.).

É importante ressaltar que o processo de decisão pessoal, conduzido pela complexa interação entre o indivíduo e seu ambiente, é flexível, adaptativo e provoca uma diversidade de comportamentos possíveis (Pilli, 2017, p. 36). O signo-cor (como qualquer outro signo) não têm 
um poder fixo ou determinístico de evocar respostas específicas, mas entender os modos cromáticos de significação e as peculiaridades do uso do signo-cor auxilia as marcas a obterem o máximo da capacidade persuasiva de suas materializações cromáticas.

\section{Cocriação: o engajamento criando valor, pela cor}

Conceitos atuais como cocriação de valor e coprodução, revelam a potência estratégia do uso da cor, no binômio consumo/produção. Cocriação é uma ideia ampla, referente às práticas de consumo "que ocorrem nas intersecções entre a marca e o consumidor ao longo do tempo, em direta interação ou mediadas pelos bens" (Lusch \& Vargo, 2006, p. 284). Por sua vez, a coprodução é parte da cocriação de valor, referindo-se à cooperação entre consumidor e produtor na criação das ofertas de uma marca, em diferentes etapas do processo produtivo, e diretamente ligada a ações de customização (Etgar, 2008).

A cor é frequentemente um dos atributos passíveis de alteração nos processos de customização de massa. Nela, o consumidor torna-se o "projetista" (das cores) e se empenha no auto-design (self-design ou user-design), com o intuito de obter o resultado que melhor encarna suas idiossincrasias preferenciais (Moreau \& Herd, 2010). Pela customização de massa, os produtos ou serviços são personalizados individualmente em larga escala, combinando os benefícios da produção de massa e da customização pura (Zipkin, 2001).

Porém, mesmo as customizações não complexas como a da cor, requerem atenção à logística-operacional, para que não sejam inviáveis economicamente:

É uma conversa logística mais do que sobre cor .... Somos a única
empresa que fabrica toda a personalização nos EUA, .... Não temos
uma grande quantidade de modelos para customização, mas os que
fazemos, temos muito material disponível para permitir os
consumidores escolherem a cor que desejam.... E pode ficar muito
amplo e muito caro rapidamente. Uma das coisas que nos tornam
únicos é que, fazendo nos EUA, nosso tempo de produção e envio
são mínimos.... As outras marcas costumam fazer no exterior...
embarques da Ásia podem ficar bastante caros. (Depoimento de
especialista - New Balance)

Uma marca que explora a customização cromática para obter diferentes tipos de engajamento é a M\&M, primeiro chocolate do mundo a incorporar a cor como fator central de diferenciação marcária (Parmar, 2004). Nas cinco lojas-conceito, localizadas em centros 
turísticos (Las Vegas, Orlando, Nova York, Los Angeles, Londres ou Shangai), os visitantes enchem seus saquinhos com até 25 opções de cores para a casquinha de açúcar (Figura 3.14).

Figura 3.14: Os consumidores escolhem as cores das pastilhas M\&Ms na loja conceito e no site.

(a)

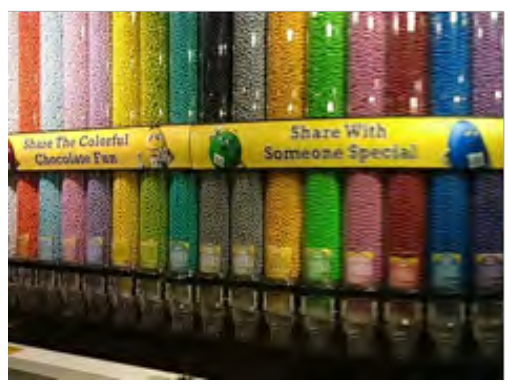

(b)

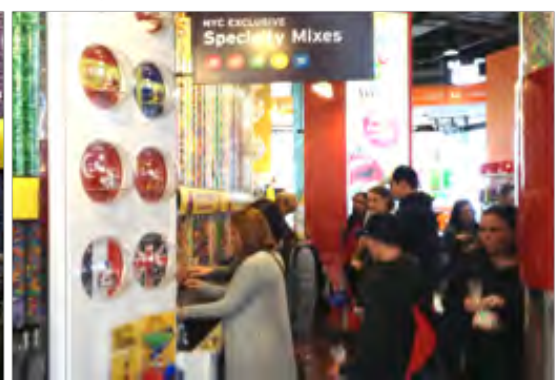

(c)

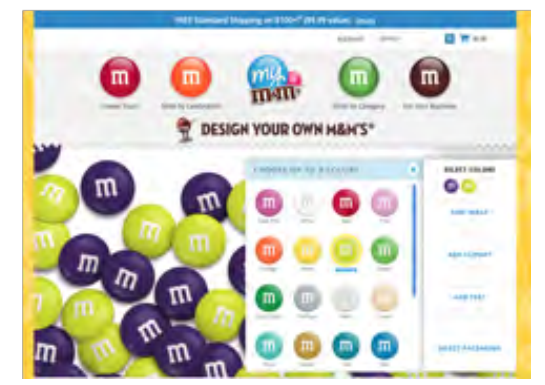

Fontes: (a, b) Visita de observação na loja-conceito de Nova York;(c) Site My MMs (M\&M - Mars, 2017).

Quando não é possível a customização em massa, o engajamento coprodutivo pode ocorrer espontaneamente, facilitados por canais de comunicação do produtor (serviços de atendimento ao consumidor, blogs e comunidades de marca, perfis da marca em redes sociais, etc.); ou ser incentivado por meio promocional, como concursos ou eleições, chamando os públicos a colaborarem na melhoria da experiência da marca que consomem.

Por exemplo, na venda massificada das pastilhas M\&M (vermelho, amarelo, laranja, verde, azul e marrom), a marca lança regionalmente "versões limitadas" com cores especiais (Figura 3.15), e frequentemente envolve sua comunidade na seleção de novos sabores, cores, texturas e recheios. A primeira eleição global de cor ocorreu em 2002, com a participação de mais de 10 milhões de pessoas: o vencedor, roxo, derrotou o verde-água e o rosa, e foi incluído nos pacotes regulares durante um ano (CNN Money, 2002). A última eleição se deu em 2012, quando 2.5 milhões de seguidores da marca no Facebook escolheram três novas cores para edições limitadas: coincidentemente, roxo, acqua e rosa-escuro (Huffington Post, 2012).

Figura 3.15: (a) Edição especial da Copa do Mundo do Brasil, e (b) edição limitada de 2012.

(a)

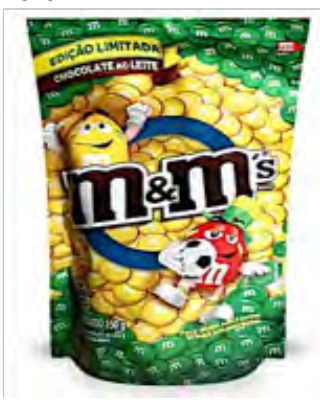

(b)

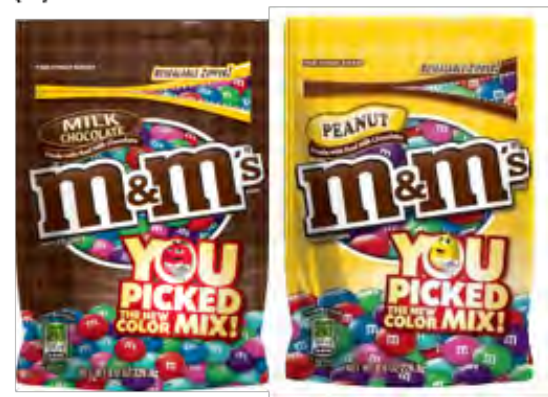

Fontes: (a) Acervo da pesquisadora, (b) Jornal Huffington Post (2012). 
O engajamento coprodutivo, por meio da cor, cria valor para a marca pois cria vínculos de sentido entre a marca e seus consumidores. Ele pode ser inserido nas categorias de rituais de arrumação e de posse (McCracken, 1986), na medida em que alteram o aspecto (ou a percepção do aspecto) intrinsicamente padronizado e massificado dos produtos e serviços. A coprodução colabora na assimilação sígnica dos bens adquiridos, estabelecendo e reforçando a propriedade dos bens (C. Campbell, 2005).

\section{Inércia e boicote: a não persuasão e a persuasão cromática inadequada}

Conforme visto, quando usadas adequadamente, as cores provocam ações benéficas para marcas. Porém, quando a capacidade sígnica cromática de prescrever comportamentos não é adequadamente utilizada, ela não incita os indivíduos-intérpretes à ação alguma, ou provoca reações prejudiciais às marcas.

Por exemplo, no intuito de agradar o máximo de clientes com variedade de opções, as marcas podem sobrecarregar seus públicos com uma oferta excessiva de cores - o que inicialmente é desejável e chama a atenção do consumidor, acaba se tornando desmotivador. O excesso de alternativas provoca o indivíduo a desistir da escolha e da compra, ou quando compra, provoca insatisfação e não o incita a recomprar (Iyengar \& Lepper, 2000). O mesmo pode ocorrer nas estratégias de customização de massa: durante a configuração individual do produto ou serviço, o consumidor pode se sentir confuso pelo excesso de cores possíveis (e outras variáveis) e abandonar o engajamento (Zipkin, 2001).

Nos casos acima, o uso da cor não foi adequadamente incitivo e provocou inércia, paralisia. A inadequação também pode ocorrer pela dimensão designativa e apreciativa do signo-cor. Por exemplo, quando a marca global usa uma cor designativa fixa, a qual possui associações não apreciadas por um público específico ou em local especifico onde a marca atua.

Em alguns lugares, as cores têm um significado tão forte que se a sede global não for flexível, não ajuda em nada... Você não pode simplesmente impor, você pode impor um pouco, mas vai custar muito mais caro e terá a resistência local, o contra-ataque do importante significado das cores que você está forçando. Em alguns casos, não é tão importante, e o dinheiro pode te levar longe. Mas por que desperdiçar o dinheiro em vez de trabalhar com o local?... Eles conhecem o mercado melhor do que você.... Eles vão sabotar! Então, não é a maneira mais eficaz de se fazer. (Depoimento de especialista - REBRAND $®$ ). 
Grandes marcas, como Coca-Cola e Bradesco, cientes que uma cor antipatizada pode causar efeitos negativos no comportamento do consumidor, adaptam suas cores em escopo local ou por um período determinado (no festival de Parintins, por exemplo). Porém, conforme discutido, nos casos onde o uso da cor for percebido como inautêntico (e.g. green/pinkwashing), as avaliações negativas podem provocar ações fortemente prejudiciais para as marcas: a protestarem publicamente contra ela e, em extremo de persuasão negativa, a pregarem o não consumo de seus produtos ou serviços - o boicote de marca (J. G. Klein, Smith, \& John, 2004).

\section{QUESTÃO 9 DA TESE:}

\subsection{Por que e como a cor é usada para organizar prévias disposições sobre a marca?}

Morris afirma que, quando um organismo utiliza um signo com o objetivo principal de organizar disposições evocadas previamente por outros signos, o uso sígnico é do tipo sistêmico. Esse uso pressupõe e altera outros usos sígnicos adequadamente realizados, por signos operando em diferentes modos (Morris, 1946, p. 104). Assim, a última proposição sobre as funções da cor como signo de uma marca, é a seguinte:

\section{Proposição 9: o adequado uso sistêmico da cor organiza visualmente a marca}

O uso sistêmico da cor (ou de uma combinação de cores) organiza as respostas que outras cores tendem a provocar, nos públicos da marca. O uso sistêmico é correto (sistematicamente adequado) quando influencia as prévias adequações dos usos informativo, avaliativo e/ou incitivo, positivamente para a marca.

Para discutir como a cor pode ser usada pelas marcas na organização de suas ofertas, esta seção segue o conceito da Ciência da Informação sobre "organizar": o processo de formar uma unidade coerente e integrada, ou de arranjar/ordenar as coisas para que possam facilmente e rapidamente serem achadas ou usadas (Joudrey, Taylor, \& Wisser, 2017, p. 1). Assim, arranjar, unir coerentemente, ou hierarquizar as materializações marcárias por meio da cor, implica e ressignifica prévios usos cromáticos para a identificação, a preferência e o engajamento de marca - em conformidade com o que afirma Morris (1946, p. 106) sobre a interdependência dos usos sígnicos. Por exemplo, estudos mostraram que a organização de 
produtos por cores (vs. apresentar misturado) aumentou a percepção de variedade e provocou um aumento na quantidade consumida (Kahn \& Wansink, 2004).

A Gestalt, escola alemã de psicologia experimental da primeira metade do século XX, auxilia no entendimento das cores como organizadoras. Pensadas na dimensão sintática, as leis Gestálticas discutem os fenômenos da percepção humana - sobretudo os visuais - que acontecem espontaneamente e puramente pela forma, sem aprendizado ou outro viés cultural (Fraccaroli, 1952). Originalmente desenvolvidas por Wertheimer (1923/1938), as leis de organização das formas perceptivas explanam sobre a tendência do ser humano em não perceber objetos ou experiências como independentes, mas como inteiros maiores, separados e relacionados uns com os outros.

Especificamente relevante na organização pelas cores, é a "lei da similaridade": os objetos que compartilham propriedades similares, como a cor, forma, orientação e tamanho, são percebidos como ligados entre si (Wertheimer, 1938, p. 75). Extrapolando a lei sintática para a dimensão semântica, produtos e serviços designados pelas mesmas cores podem ser percebidos como pertencentes à mesma marca, ou como possuidores de atributos e valores comuns. $\mathrm{O}$ contrário também é válido: materializações marcárias com cores dissimilares não estabelecem, ao menos pelo aspecto cromático, noção de agrupamento ou unidade.

Na prática, a cor é frequentemente usada para auxiliar visualmente na organização do portfólio de ofertas de uma marca (variedade de cores do produto, extensão de linha, coleções de moda), na extensão dessa marca para outras categorias, e na estruturação da hierarquia do portfólio, desde a marca corporativa até às variações dos produtos e serviços.

\section{Categorização: a cor apoiando as extensões de marca}

No cenário competitivo de hoje, a marca não deve ficar restrita a uma única oferta fundadora: ela deve expandir suas ofertas para fazer sentido a um grupo maior de pessoas, atender a necessidades que não atendia antes, responder a novos gostos e tendências, e enfrentar novos lançamentos de competidores (Raig \& Tybout, 2005, pp. 91-92). Em um olhar semiótico sobre a extensões de marca, o processo de segmentar e/ou ampliar a atuação marcária com a introdução de novos produtos e serviços, se trata de uma ressignificação da marca original, que passa a ser uma marca-mãe (marca guarda-chuva ou marca-família).

Quando usada corretamente na função sistêmica, a cor auxilia na organização de diferentes ofertas sob uma mesma categoria/marca, unificando ou diferenciando conforme os 
objetivos estratégicos. As propriedades visuais marcárias, incluindo a cor, influenciam a categorização de produtos e serviços e, subsequentemente, a configuração das crenças dos consumidores em relação à marca (Karjalainen, 2007).

Quando são apresentados a extensões de marca, os consumidores se envolvem em um processo de categorização, onde a nova oferta é avaliada em relação ao conceito/categoria da marca-mãe, que possui uma ou mais ofertas sob sua identificação. As associações da marcamãe só serão transferidas para a "filha" se os consumidores perceberem uma certa adequação ou encaixe entre elas - que depende da percepção de similaridade de atributos e do quanto a marca-mãe é conceitualmente consistente (Park, Jaworski, \& Maclnnis, 1986).

Um exemplo completo de extensão é o da "barra de beleza" Dove, marca lançada em 1957 nos EUA, e oferecida no Brasil em 1992, já com as cores designadoras atuais: o branco em profusão (em referência ao 1/4 de creme hidratante de sua composição) e o azul marinho, cor da empresa produtora, a Unilever. Na fase inicial da expansão horizontal da marca (Figura 3.16), posicionada para o público feminino e com apenas uma opção de fragrância - sabonete líquido (lançado no Brasil em 1997), desodorante (1999), loção hidratante (2001), shampoo e condicionadores (2002) - as extensões eram "marcadas" consistentemente com o branco no corpo da embalagem e o azul na tampa e no logotipo.

Figura 3.16: (a) Lançamento e primeiras extensões da marca Dove no Brasil (1992-2002).
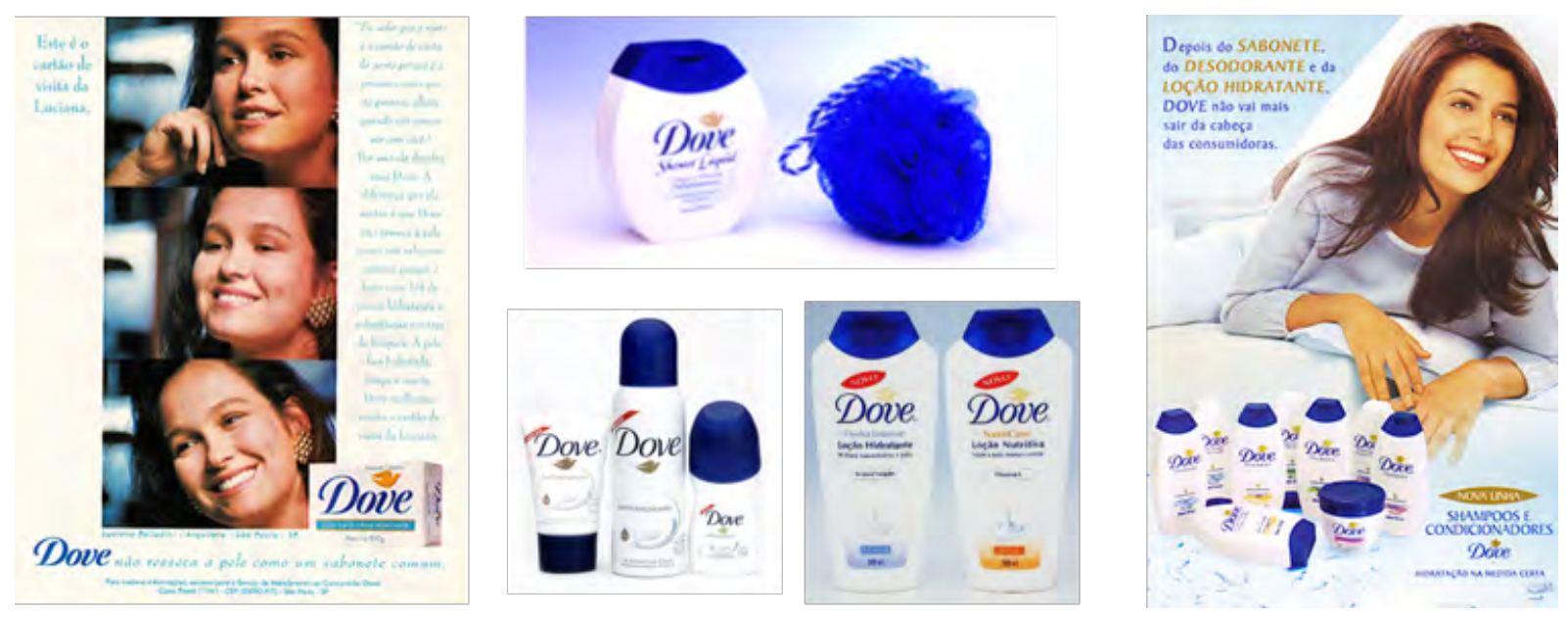

Fonte: (a) Site História da Unilever-Dove (Unilever, 2017).

Porém, na renovação estratégica da Unilever, em 2000, a Dove foi uma das selecionadas para atuar como "marca máster" da empresa, destinada a ser guarda-chuva global de produtos em uma maior amplitude de ofertas (Deighton, 2007). Assim, no mercado brasileiro, a Dove se expandiu com linhas especiais para cabelos (a partir de 2007) e para o 
público jovem (desde 2008, pela linha Go Fresh), com diferentes fragrâncias nos sabonetes, desodorantes e loções (Figura 3.17).

Figura 3.17: Algumas das ofertas atuais da Dove, o branco em combinação com várias cores.

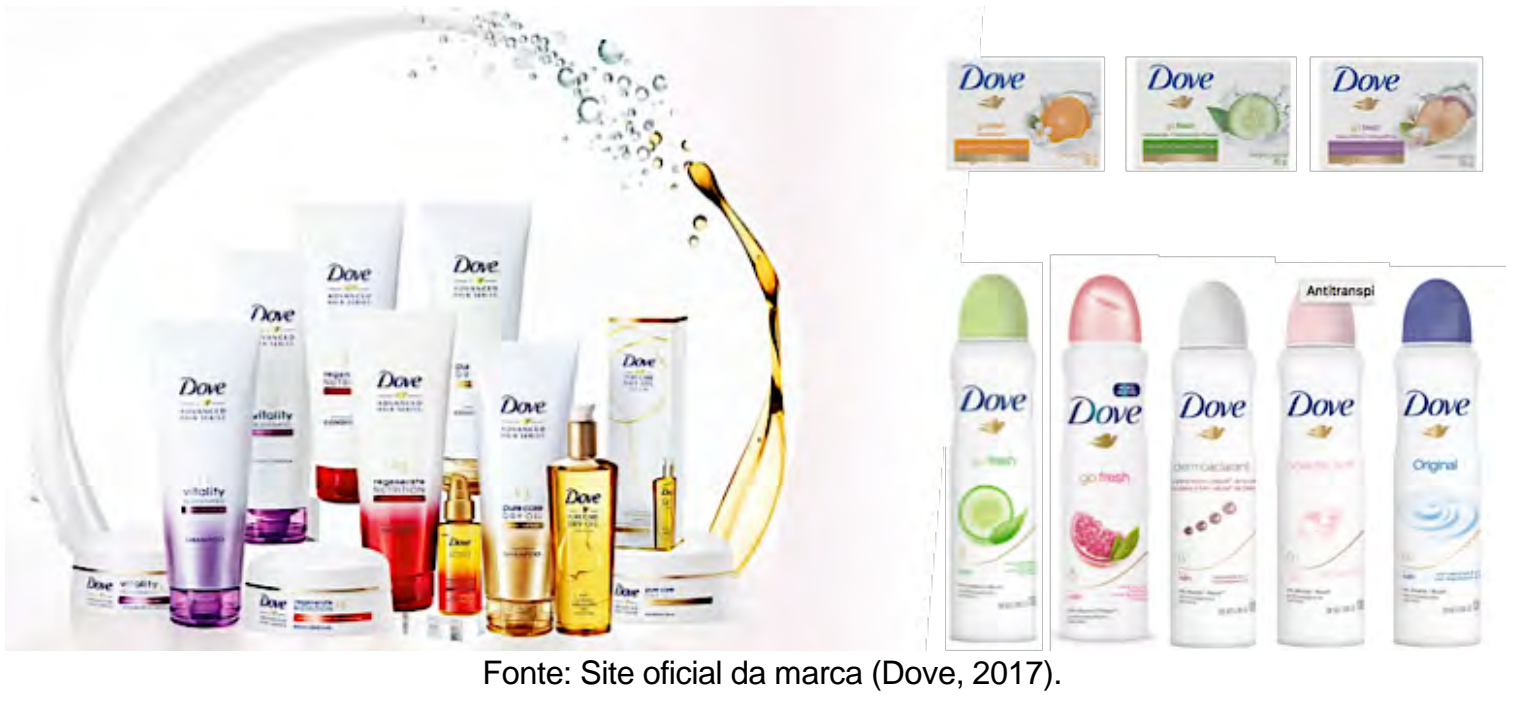

Apoiando a estratégia de expansão, a combinação cromática tradicional deu espaço a novas duplas de cor: o branco usado para unificar sob o guarda-chuva, e cores variadas para informar a especialidade ou o ingrediente aromático-funcional, diferenciando e renovando os sentidos da marca-família Dove. O azul marinho, que identifica a marca no logotipo, informa a versão de fragrância "original", quando aplicado na tampa.

Ao aplicar repetidamente os elementos de design em suas ofertas, a empresa objetiva ensinar o consumidor que os novos produtos ou serviços pertencem a uma mesma marca. Porém, a repetição pode incitar o tédio e reduzir a atenção para os valores marcários, expressos através do design (Karjalainen \& Snelders, 2010). Portanto, o equilíbrio entre a inovação na cor e a consistência do seu uso é crucial para o uso sistêmico ser adequado, o que inclui não prejudicar o reconhecimento visual da marca (uso informativo), não criar rejeição ou depreciação (uso avaliativo) e não prejudicar as vendas e outros comportamentos (uso incitivo).

O uso da cor como auxiliar na inovação marcária em territórios perceptualmente distantes da marca-mãe, é exemplificado no lançamento da Dove Men+Care, em 2010. Além do identificador verbal ("homens"+ "cuidados", em tradução livre) a cor foi usada para diferenciar as propostas, reorganizando o portfólio. As embalagens masculinas (Figura 3.18a) são cromaticamente opostas às femininas: o cinza escuro designa os produtos quase na totalidade e o branco é aplicado apenas no logotipo Dove: uma versão acromática e em negativo das embalagens da marca-mãe. 
Na extensão para cuidados com bebês (em 2015), mais próxima semanticamente do universo feminino, o branco voltou a dominar. As cores também organizam o portfólio Baby Dove: a tampa azul-esverdeada informa a linha hidratação enriquecida, a tampa branca identifica a linha para peles sensíveis (Figura 3.18b).

Figura 3.18: Extensões da Dove, em sub-marcas: (a) Dove men + Care; (b) Baby Dove.

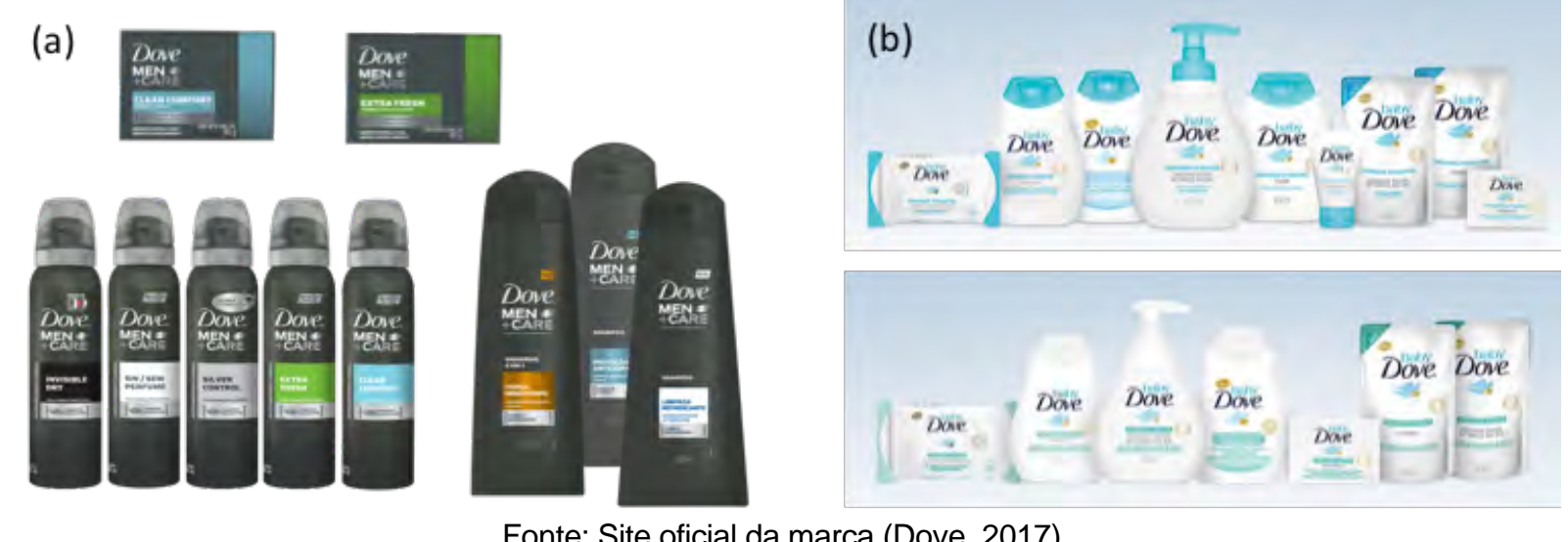

Em lançamentos, como os recentes da Dove, que implicam na criação de novas marcas e submarcas, ou que impactam a marca corporativa e outras marcas da mesma empresa, a extensão é parte de uma estratégia mais abrangente, a de arquitetura de portfólio marcário.

\section{Classificação: a cor expressando a arquitetura do portfólio de marcas}

Além de apoiar a categorização de produtos e serviços sob o mesmo guarda-chuva, a cor também é usada para auxiliar na organização geral das marcas dentro do portfólio de uma empresa. Nesse caso, a cor participa de uma classificação hierárquica - processo estruturado para arrumar sistematicamente (coisas, informação, conceitos, etc.) de acordo com princípios pré-determinados (Joudrey et al., 2017, p. 541). Para maximizar seus esforços de gestão e de comunicação, as empresas precisam estipular uma linha-guia de decisão sobre quais os produtos e serviços elas devem oferecer, e sob qual marca eles serão identificados, comunicados, vendidos: a estratégia de arquitetura de marca, com seus quatro modelos básicos.

Por esse sistema classificador são determinados os elementos identificadores de marca (nome, logo, cores, símbolos) para que os consumidores entendam (memorizem, prefiram e comprem) as ofertas (K. L. Keller, 2015). Na estratégia de portfólio monolítica, todos os produtos ou serviços são comercializados sob um única (mono)marca; na estratégia de submarcas, a marca-mãe se subdivide para alcançar públicos e nichos com mais apelo e 
especificidade, porém sem romper com os valores que caracterizam a família. Na estratégia de marcas endossadas, a empresa possui diferentes marcas, mas todas recebem o endosso corporativo, visual e verbal. A estratégia de marcas independentes é a mais onerosa e flexível, a empresa tem inúmeras marcas sem qualquer vínculo aparente entre elas, e raramente os consumidores sabem que são geridas pela mesma companhia (Aaker \& Joachimsthaler, 2000).

Um exemplo de estratégia monolítica guiada pela cor é a Louboutin (Figura 3.19). Originalmente do setor de alto luxo, a marca se expandiu verticalmente para categorias mais acessíveis (masstige, prestígio de massa): dos sapatos e bolsas (U\$3.990) a marca estendeu-se, recentemente, até chaveirinhos (U\$40). O vermelho patenteado das solas foi elemento chave na extensão para acessórios de couro, aplicado no forro interno e em detalhes das bolsas. Em 2014, o vermelho foi a característica unificadora na extensão para categoria de beleza: esmaltes vermelhos. Esse produto é parte importante da história da marca, já que a assinatura cromática foi criada quando Christian Louboutin, ao ver uma modelo pintado as unhas, pegou o vidrinho e pintou rapidamente as solas, pouco antes de um desfile começar, em 1993 (L. Collins, 2011).

Figura 3.19: Extensões da Louboutin: bolsa, batom, chaveiro, lápis de olho e esmaltes.
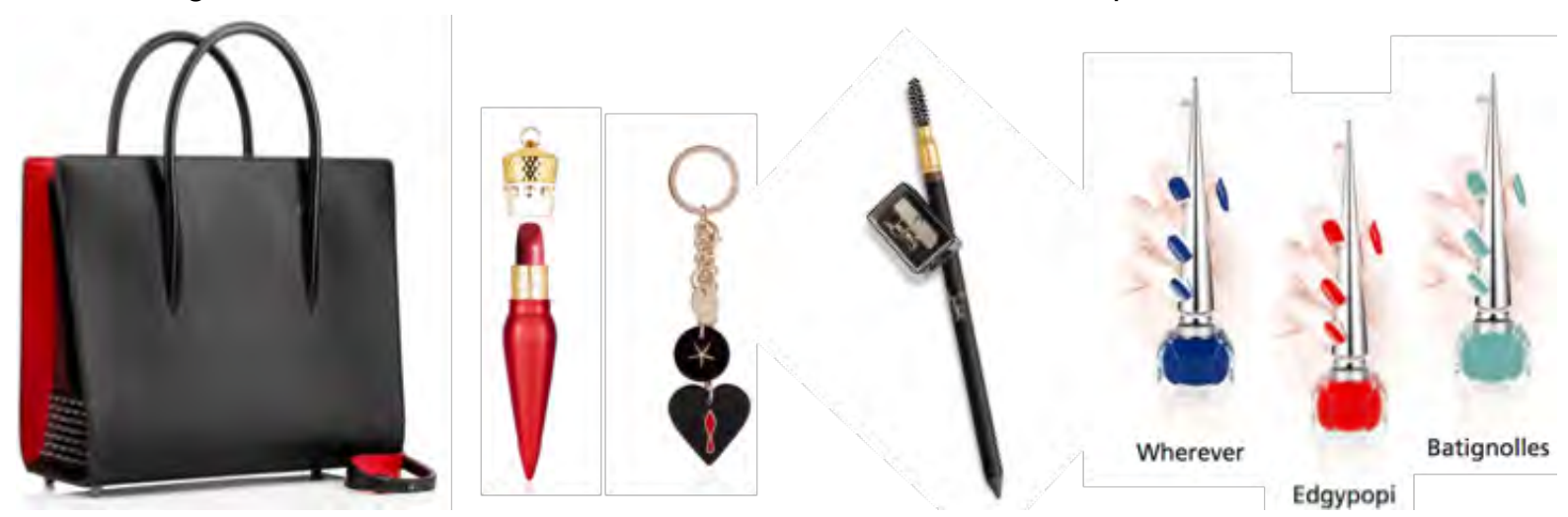

Fonte: Site/loja da marca (Louboutin, 2017).

Reforçando a atuação em beleza, em 2015 a marca lançou batons e em 2016 os perfumes, primeira vez sem a obrigatoriedade do vermelho. Em 2017, foi lançada a linha de maquiagem para os olhos e novos esmaltes, sem vermelho na embalagem ou no produto.

Quando um produto é icônico [de marca], como um sapato de salto-alto com sola vermelha, se você quer estender para novas categorias, como você os liga? A estratégia foi 'siga a linha vermelha'. Como você incorpora isso nas bolsas, produtos de beleza, e outras categorias, mantendo-se fiel às suas solas vermelhas originais? Então, é muito importante unir tudo isso, sempre ter algum vermelho em cada produto. (Depoimento de especialista - Louboutin). 
Um exemplo da cor expressando uma arquitetura de submarcas, é o banco Itaú (Figura 3.20). O laranja identitário é usado em diferentes proporções e tons, a depender da submarca desenvolvida para cada perfil de correntista físico (Itaú, Itaú Uniclass, Itaú Personnalité, Itaú Private Bank) ou jurídico (Itaú ou Itaú BBA), mantendo uma unidade e ao mesmo tempo diferenciando e hierarquizando.

Figura 3.20: Pirâmide de segmentação do Itaú, organizada com o auxílio da cor.

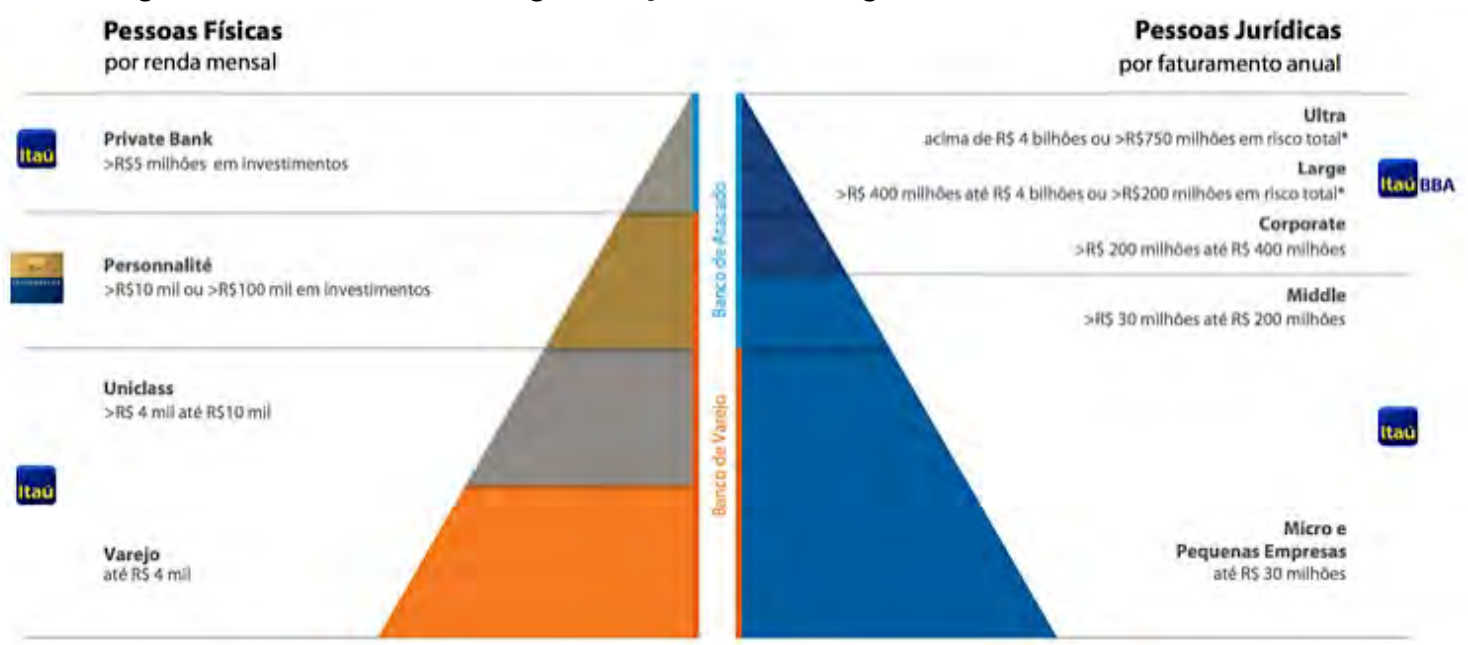

Fonte: Apresentação institucional (Itaú, 2017a, p. 26)

Diferentemente das estratégias monolítica e de submarca, os portfólios endossados não usam obrigatoriamente a cor para a uniformização, uma vez que a intenção é ter liberdade e flexibilidade na criação das marcas. Por exemplo, no portfólio majoritariamente endossado da Danone no Brasil (Figura 3.21), cada marca explora uma paleta cromática própria, embora o azul corporativo seja frequente nos logotipos, embalagens e propagandas das marcas, como um endosso cromático sutil. Na categoria de nutrição especializada, a empresa uniformizou as ofertas com o uso do roxo-azulado.

Figura 3.21: Portfólio de marcas majoritariamente endossadas da Danone, no Brasil.

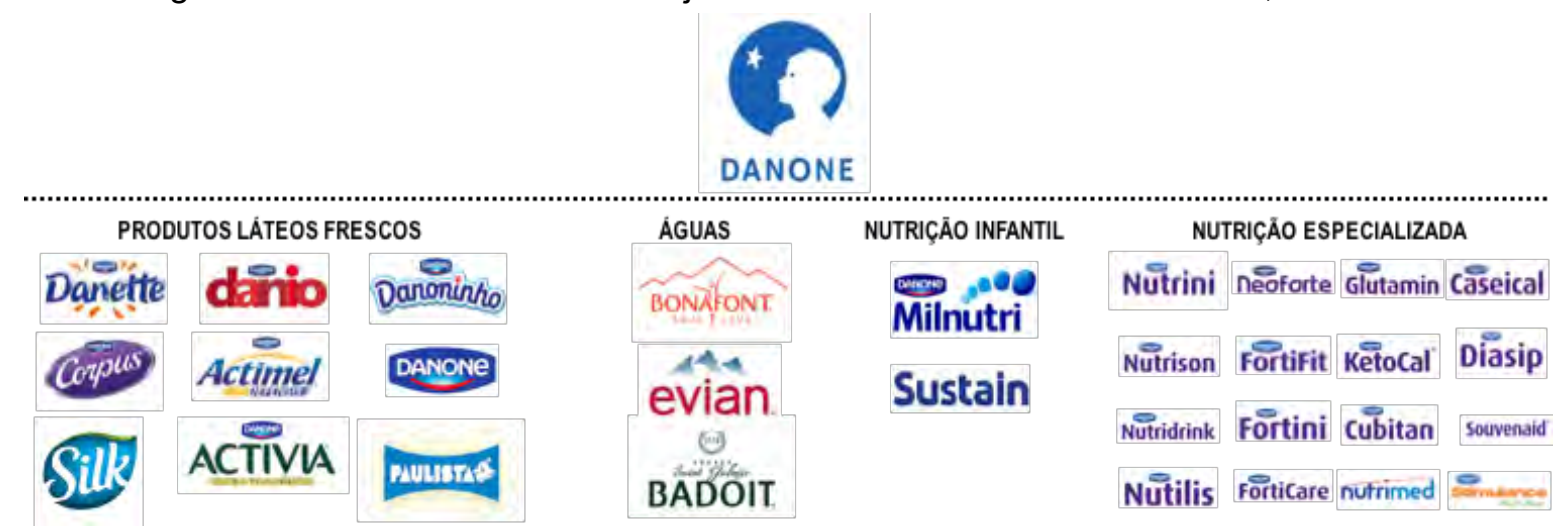

Fonte: Criado pela autora com logotipos do site oficial (Danone, 2017). 
Em portfólios de estratégia independente, não há nenhum tipo de categorização ou classificação por cor - ao contrário, ao objetivo é diferenciar ao máximo as marcas umas das outras, como no exemplo da P\&G (Figura 3.22).

Figura 3.22: Portfólio de marcas independentes da P\&G, no Brasil.

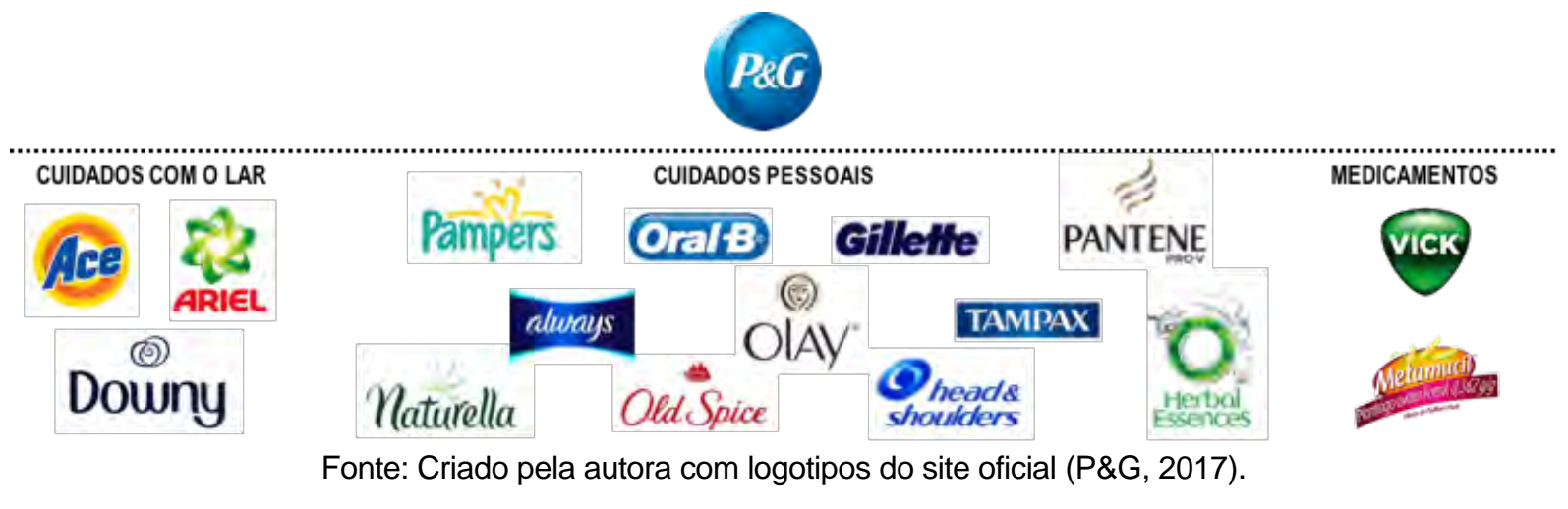

Outro exemplo é o da Ford Motor Company, detentora das marcas Ford e Lincoln. A decisão sobre o uso das cores nos veículos é realizada por uma única equipe, com o objetivo de diferenciar visualmente as ofertas mais acessíveis (Ford) das de luxo (Lincoln):

Na Ford, temos muita diversidade de produtos dentro da marca. Tudo, de um caminhão pequeno a um grande, de veículos utilitários e veículos comerciais .... Na Ford, as cores são intensas, primárias mais ousadas, além das cores claras e escuras: ... o vermelho intenso, azuis intensos, alguns verdes mais fortes, mas não temos esse tipo de coisas na Lincoln.

$\ldots$

Na Lincoln temos apenas carros e SUVs, e adotamos uma abordagem mais de luxo. Nossas cores e materiais são premium... cores escuras e sofisticadas ou cores mais claras e complexas, como os brancos especiais, cores muito claras. Podemos ter algumas cores de tendência.... Para as cores externas, existe uma tecnologia chamada Tri-code, que aplica muitas camadas de tinta para se obter um efeito de profundidade. Isso dá muito movimento nas cores, e parecerá mais luxuoso. (Depoimento de especialista - Ford Motor Company)

Assim, seja em consumo de massa ou luxo, produtos ou serviços, as cores podem ser corretamente usadas para organizar as ofertas de marca. Porém, cientes que a cor não é totalmente autônoma na significação marcária, gestores e comunicadores devem utilizar outros elementos de identidade e comunicação coerentemente com as cores, para adequadamente informar e organizar o portfólio, a fim de que seus públicos avaliem e ajam positivamente em relação às marcas. 


\title{
Bagunça: quando a cor desorganiza a marca
}

Quando a marca, por meio das cores, não atinge seus objetivos de organização, o uso da cor foi sistemicamente inadequado. Apesar das respostas positivas que a categorização ou classificação por cores provoca nos públicos internos/colaboradores da marca, a empresa deve frequentemente verificar se os efeitos interpretativos que o signo-cor produz na mente dos indivíduos são os intencionados. Frequentemente, o que parece claro e organizado para os gestores, não é compreendido pelos consumidores, como o caso do Carrefour no Brasil (Figura 3.23), conforme relatado em depoimento de um colaborador:

\begin{abstract}
A gente percebeu que as pessoas não têm claro que o laranja é o Carrefour Express, para vizinhança, que o verde é Carrefour Bairro, para o dia-a-dia.... Na pesquisa, nós sentimos que as pessoas gostam da cor, mas não conseguem explicar bem o porquê. A gente acha que é só mudar as cores, que as pessoas vão entender que são formatos de loja diferentes. Muitas vezes não, elas nem sabem que aquilo é um outro formato.

$\ldots$

Hoje usamos a cor para organizar, mas essa discussão está surgindo na França, se deveríamos usar para todos os tipos de loja uma mesma cor. Já que não tem diferença para o consumidor, por que que eu tenho investimentos em fazer tantas coisas diferentes? Por que eu não tenho tudo na mesma cor da marca-mãe? (Depoimento de especialista - Carrefour)
\end{abstract}

Figura 3.23: (a) Logotipo da marca-mãe nas cores corporativas vermelho, branco e azul; (b) Fachada com do Carrefour Express, em laranja; (c) Fachada do Carrefour Bairro, em verde.

(a)
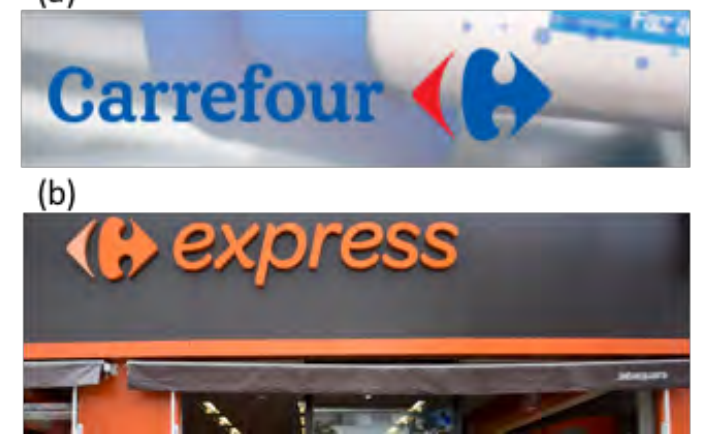

(c)

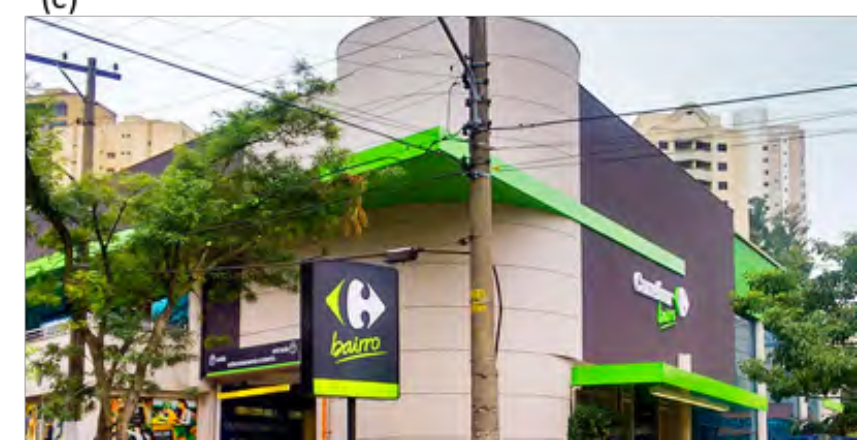

Fonte: Site oficial da marca (Carrefour, 2017).

Um exemplo de desorganização pelo uso da cor é o das latinhas Arctic Home da Coca-Cola, em campanha de 2011 (ver seção 2.2). Devido ao uso da cor não adequado, a latinha promocional do refrigerante normal (em branco e prata) foi confundida como a versão diet (usualmente nessas cores). Em 2016, a marca voltou a aplicar os ursos mascotes nas latas 
de fim-de-ano (Moye, 2016), mas dessa vez usou as cores seguindo o código cromático organizador já estabelecido na mente dos seus consumidores (Figura 3.24).

Figura 3.24: As cores organizando, nas latas (a) regulares e (b) promocionais da Coca-Cola.

(a)

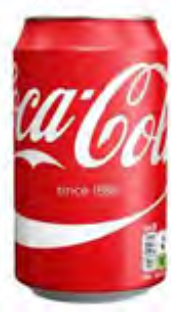

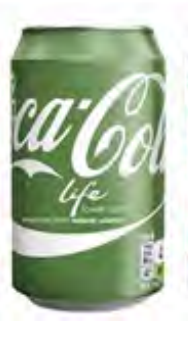

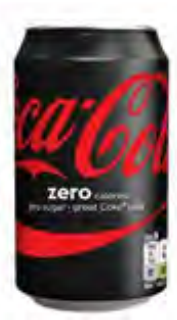

Fonte: Site oficial (Cola-Cola Company, 2016). (b)
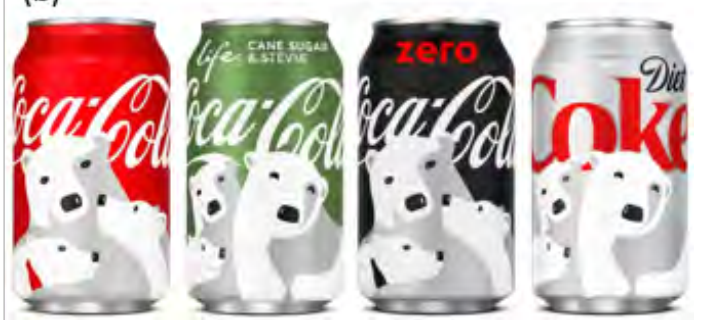

Analisar e organizar informações, conhecimentos (e posses) parece ser uma motivação básica do ser humano, ligada à necessidade de reaver ou recuperar essas ideias e objetos, e assim compreender, fazer sentido do mundo em que se vive (Joudrey et al., 2017, pp. 2-3). A complexidade da utilização das cores na função sistêmica se dá por ela depender, e ao mesmo tempo alterar, os prévios usos cromáticos para a identificação, a preferência e o engajamento de marca - confirmando, mais uma vez, a interdependência dos usos sígnicos (Morris, 1946, p. 106).

\subsection{Síntese dos usos do signo-cor pelas marcas}

Os quatro usos sígnicos definidos por Morris (1946) foram aqui repensados e adaptados em quatro proposições sobre o uso do signo-cor pelas marcas (Quadro 3.2).

Quadro 3.2: Proposição dos usos do signo-cor pelas marcas, com benefícios e riscos.

\begin{tabular}{|c|l|c|c|c|}
\hline \multicolumn{2}{|c|}{$\begin{array}{c}\text { PROPOSIÇÕES SOBRE OS USOS } \\
\text { DAS CORES PELAS MARCAS }\end{array}$} & $\begin{array}{c}\text { BENEFicIOS } \\
\text { PARA AS } \\
\text { MARCAS }\end{array}$ & $\begin{array}{c}\text { USO } \\
\text { USOS SígNICOS } \\
\text { (MORRIS,1946) }\end{array}$ & $\begin{array}{c}\text { INADEQUADO: } \\
\text { RISCOS PARA } \\
\text { AS MARCAS }\end{array}$ \\
\hline P6 & $\begin{array}{l}\text { O adequado uso informativo da cor } \\
\text { promove a identificação da marca }\end{array}$ & $\begin{array}{c}\text { Consistência } \\
\text { Diferenciação }\end{array}$ & $\begin{array}{c}\text { USO } \\
\text { INFORMATIVO }\end{array}$ & $\begin{array}{c}\text { Confusão; } \\
\text { Depreciação }\end{array}$ \\
\hline P7 & $\begin{array}{l}\text { O adequado uso avaliativo da cor } \\
\text { promove a preferência pela marca. }\end{array}$ & $\begin{array}{c}\text { Originalidade } \\
\text { Relevância }\end{array}$ & $\begin{array}{c}\text { USO } \\
\text { AVALIATIVO }\end{array}$ & $\begin{array}{c}\text { Desconfiança e } \\
\text { Rejeição. }\end{array}$ \\
\hline P8 & $\begin{array}{l}\text { O adequado uso incitivo da cor } \\
\text { provoca o engajamento de marca. }\end{array}$ & $\begin{array}{c}\text { Versatilidade } \\
\text { Normatização } \\
\text { Cocriação }\end{array}$ & $\begin{array}{c}\text { USO } \\
\text { INCITIVO }\end{array}$ & $\begin{array}{c}\text { Inércia; } \\
\text { Boicote. }\end{array}$ \\
\hline P9 & $\begin{array}{l}\text { O adequado uso sistêmico da cor } \\
\text { organiza visualmente a marca. }\end{array}$ & $\begin{array}{c}\text { Categorização } \\
\text { Classificação }\end{array}$ & $\begin{array}{c}\text { USO } \\
\text { SISTÊMICO }\end{array}$ & Bagunça. \\
\hline
\end{tabular}

Fonte: Desenvolvido pela autora. 
Conforme discutido, Morris define a adequação de cada uso pela obtenção das intenções do seu produtor, e não pela satisfação das necessidades ou expectativas dos intérpretes (1946, p. 106). Assim, pela teoria Morrisiana, o uso convincente do signo-cor em identificar a marca, e seus atributos, não implica que as informações sejam verdadeiras; o uso eficaz em gerar preferência pela marca não implica que a marca seja a melhor para o consumidor; o uso persuasivo não implica que as ações resultantes sejam as mais indicadas para quem comprou, customizou, postou.

Porém, informar adequadamente, convicentemente, algo que não é verdadeiro, em um médio ou longo prazo pode se tornar inadequado - se os públicos se informarem sobre a marca por outras ou novas vias -, comprometendo o potencial sígnico da cor e da marca como um todo. O mesmo se dá com os outros usos e suas adequações, seus potenciais benefícios e riscos.

A questão da adequação é, assim, diretamente relacionada a outros dois fatores: a verdade e a confiabilidade sígnicas. A verdade de um signo acontece se ele denota, naquele instante, as características, as apreciações e as ações que significou junto aos intérpretes; a confiabilidade de um signo se dá na medida em que ele denota, ou não, nas diversas vezes em que aparece ao intérprete: do 100\% ao nada confiável (Morris, 1946, pp. 106-107). Um signo pode ser ou não verdadeiro ou confiável, e ser ou não acreditado ou conhecido como tal (1946, p. 109).

Na era das fake news e da pós-verdade, da sociedade do consumo, das imagens e do espetáculo, o que acontece com o potencial sígnico de uma cor usada falsamente? É esvaziada de sentido, naquele contexto de mercado, ou não? E as marcas que falsamente usam as cores, mantêm a capacidade de informar, avaliar, persuadir, organizar, em seus discursos marcários? Por quanto tempo? No caso negativo - a marca perdendo seu valor sígnico e, portanto, financeiro - frequentemente a saída é um incerto e oneroso processo de reposicionamento: ou se ressignifica, ou morre. Mas um rebranding, com novas cores e novos valores, dará conta? Uma estratégia adequada? Verdadeira? Confiável? Quem viver, verá. 


\section{Tipologia semiótica dos discursos cromáticos de marca}

Tipologias, um tipo especial de classificação, são arranjos conceituais e multidimensionais, cujas dimensões (ou eixos) estão relacionadas e formadas por dados categóricos (Bailey, 1994, p. 4). Na tipologia semiótica dos discursos de Morris (1946), quatro modos de significação são correlacionados com os quatro usos sígnicos, estipulando 16 tipos principais de discursos semióticos cotidianos (Quadro 4.1) - cada um deles nomeado ilustrativamente.

Quadro 4.1: Os principais tipos de discursos semióticos, segundo Morris.

\begin{tabular}{|cc|c|c|c|}
\hline MODO & INFORMATIVO & AVALIATIVO & INCITIVO & SISTÊMICO \\
\hline DESIGNATIVO & $\begin{array}{c}\text { científico } \\
\text { (designativo-informativo) }\end{array}$ & $\begin{array}{c}\text { fictício } \\
\text { (designativo-avaliativo) }\end{array}$ & $\begin{array}{c}\text { legal } \\
\text { (designativo-incitivo) }\end{array}$ & $\begin{array}{c}\text { cosmológico } \\
\text { (designativo-sistêmico) }\end{array}$ \\
\hline APRECIATIVO & $\begin{array}{c}\text { mítico } \\
\text { (apreciativo-informativo) }\end{array}$ & $\begin{array}{c}\text { poético } \\
\text { (apreciativo-avaliativo) }\end{array}$ & $\begin{array}{c}\text { moral } \\
\text { (apreciativo-incitivo) }\end{array}$ & $\begin{array}{c}\text { crítico } \\
\text { (apreciativo-sistêmico) }\end{array}$ \\
\hline PRESCRITIVO & $\begin{array}{c}\text { tecnológico } \\
\text { (prescritivo-informativo) }\end{array}$ & $\begin{array}{c}\text { político } \\
\text { (prescritivo-avaliativo) }\end{array}$ & $\begin{array}{c}\text { religioso } \\
\text { (prescritivo-incitivo) }\end{array}$ & $\begin{array}{c}\text { propagandístico } \\
\text { (prescritivo-sistêmico) }\end{array}$ \\
\hline FORMATIVO & $\begin{array}{c}\text { lógico-matemático } \\
\text { (formativo-informativo) }\end{array}$ & $\begin{array}{c}\text { retórico } \\
\text { (formativo-avaliativo) }\end{array}$ & $\begin{array}{c}\text { gramatical } \\
\text { (formativo-incitivo) }\end{array}$ & $\begin{array}{c}\text { metafísico } \\
\text { (formativo-sistêmico) }\end{array}$ \\
\hline
\end{tabular}

Fonte: Traduzido de Morris (1946, p. 125).

Apesar de desenvolvida para qualquer tipo de combinação sígnica (cruzamento dos modos e usos), Morris revela que os signos verbais foram o foco da sua tipologia. Nas palavras do autor, "a linguagem diariamente falada [speech] é um surpreendentemente intricado complexo sígnico, que contém signos em todos os modos de significação, servindo a uma vasta variedade de intenções” (1946, p. 123). Segundo ele, para que essas intenções fossem adequadamente alcançadas, as "especializações de linguagem" surgiram ao longo do tempo, denominadas como "tipos de discursos". A predominância do verbal é também explicitada no detalhamento de cada tipo discursivo, onde repetidamente o intérprete é chamado de "leitor".

Ao denominar as especializações da linguagem como discursos cotidianos, Morris seguia os pressupostos de seu mestre-orientador, George Mead: "um universo de discurso é 
simplesmente um sistema de significados em comum, sociais" (G. H. Mead, 1934/1972, pp. 8990). Essa conceituação de "universo do discurso" como um processo social de experiência e comportamento, no qual os significantes possuem significações comuns para os membros do grupo, insere-se no contexto do pragmatismo filosófico de Peirce, que também usava a expressão (R. Keller, 2013, p. 6).

Seguindo a esquemática Morrisiana, a tipologia aqui proposta correlaciona quatro modos de uma cor significar uma marca com os quatro principais usos do signo-cor, estabelecendo não 16, mas 13 especializações de discursos cromáticos. A redução se deu pela junção dos quatro tipos de discurso na função sistêmica em um só discurso, multimodal em significação (Quadro 4.2). Do mesmo modo que Morris nomeou os 16 possíveis discursos com termos ilustrativos, a tipologia aqui apresentada também criou nomes ilustrativos para cada um dos discursos cromáticos de marca.

Quadro 4.2: Os principais tipos de discursos cromáticos das marcas.

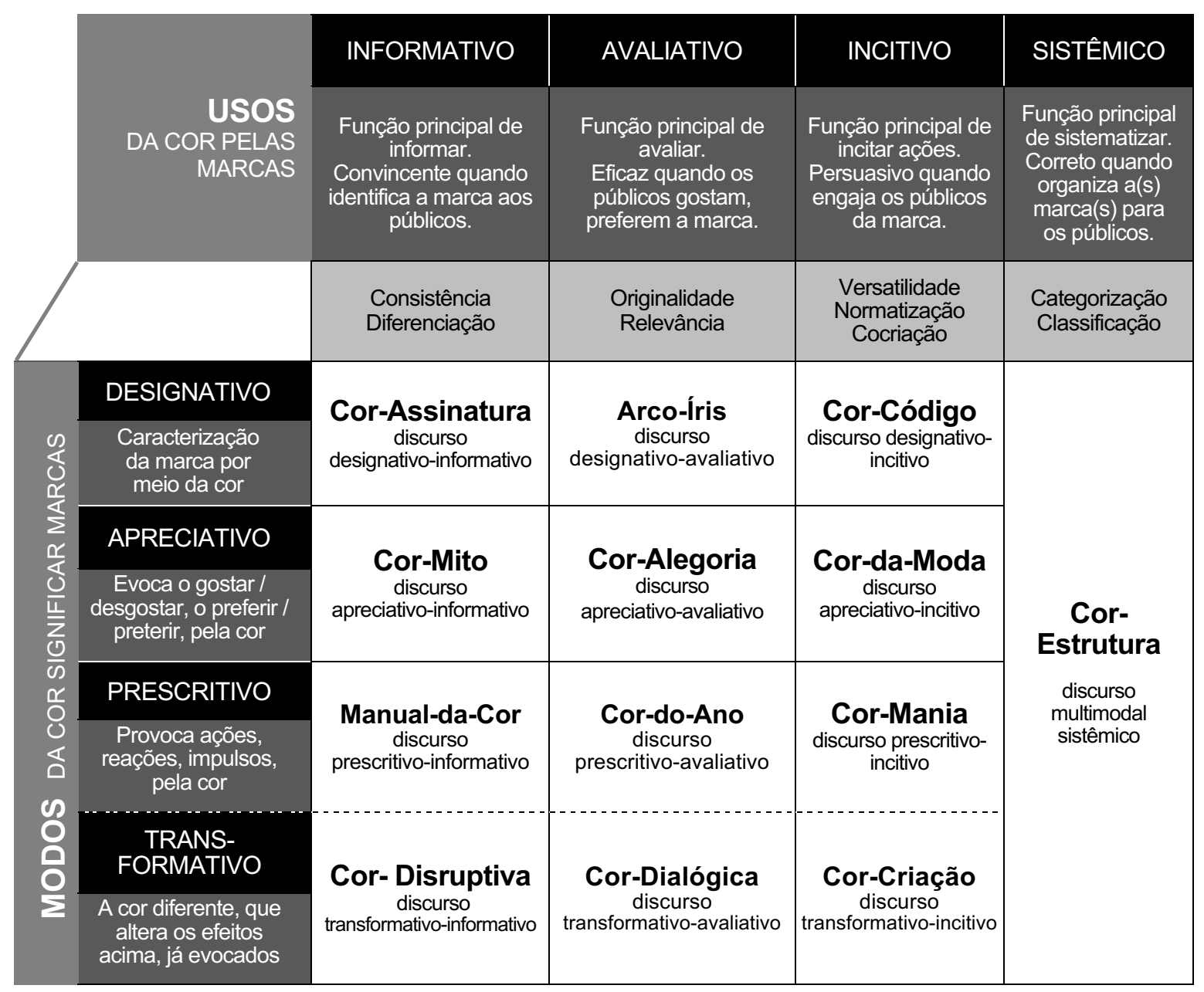

Fonte: Desenvolvido pela autora. 
A interdependência dos diferentes modos de significação e dos usos sígnicos, discutida nos capítulos anteriores, é válida também para os discursos cromáticos. Por exemplo, quando uma marca que pretende, em uma única peça publicitária, incitar os públicos a comprála (uso incitivo) por meio de novas cores (operando assim no modo transformativo) e, simultaneamente, informar os públicos (uso informativo) por meio dessas novas cores - que podem ser positivamente apreciadas no contexto específico (modo apreciativo). Assim, essa materialização visual exemplificada poderia ser classificada tanto como um discurso cromático de "cor-criação" (transformativo-incitivo) quanto como "cor-mito" (apreciativo/informativo). Os discursos cromáticos são interdependentes e não excludentes.

Se até aqui a tese focalizou as cores o mais isoladamente possível, para a configuração da tipologia isso não é possível. No plano visual marcário, as cores não existem sozinhas, mas sempre aplicadas às formas gráficas (logotipos, mascotes, tipografia), na figura ou no fundo das embalagens, produtos, propagandas, ambientações, etc. Em cada peça de comunicação, a cor é parte integrante, junto a outros elementos verbais e visuais, de uma combinação sígnica pensada e executada pela marca, um discurso de marca.

Além disso, ao se considerar a dimensão verbal, tanto o modo quanto o uso da cor tornam-se mais evidentes e, assim, passíveis de classificação.

O material verbal serve principalmente como um facilitador
que instrui o visualizador/leitor nas propriedades salientes que
deveriam ser expressas pela parte visual do anúncio. Texto
(especialmente títulos) torna explícito o que já está implícito na
imagem. O texto fornece instruções sobre como a parte visual do
anúncio deve ser lida. O componente verbal permite que o diretor
(criador da campanha) direcione a atenção do observador/leitor
exatamente para as propriedades significativas que se destinam
à transferência. (McCracken, 1986, p. 75)

Os discursos cromáticos são apresentados, a seguir, em função dos objetivos comunicacionais pretendidos por uma marca, ou seja, agrupados conforme os quatro usos principais do signo-cor (os eixos verticais da tipologia): informar, provocar uma avaliação, incitar uma ação e organizar as marcas para seus públicos. 


\subsection{Os discursos cromáticos para identidade de marca}

Discursos cromáticos que promovem a identidade marcária são aqueles onde a função principal da cor é gerar conhecimento da marca, informar suas características, personalidade e benefícios, na mente-interpretante, esteja a cor operando prevalentemente no modo designativo, apreciativo, prescritivo ou transformativo (Quadro 4.3).

Quadro 4.3: Os quatro tipos de discursos voltados para a identidade de marca.

\begin{tabular}{|c|c|}
\hline MODO & USO \\
\hline DESIGNATIVO & Cor-Assinatura (discurso marcário designativo-informativo) \\
\hline APRECIATIVO & Cor-Mito (discurso marcário apreciativo-informativo) \\
\hline PRESCRITIVO & Manual-da-Cor (discurso marcário prescritivo-informativo) \\
\hline TRANSFORMATIVO & Cor-Disruptiva (discurso marcário transformativo-informativo) \\
\hline
\end{tabular}

Fonte: Desenvolvido pela autora.

Os elementos visuais do mix de identidade da marca (Lencastre, 2007, p. 54) - logotipo, mascote, embalagem, e o design proprietário (de um produto, expositor, edificação, etc.), brand books e manuais de aplicação de marca - são especialmente criados para proferirem esses tipos de discursos, embora qualquer manifestação marcária informe, implícita ou explicitamente, sobre a marca. Além disso, campanhas conceituais ou institucionais (de um produto, serviço, empresa, ONG, celebridade, etc.), comunicados oficiais (via assessoria de imprensa, por exemplo) também podem informar, com o apoio da cor.

\section{A Cor-Assinatura (discurso cromático designativo-informativo)}

O discurso cromático da cor-assinatura refere-se à interação do modo designativo com o uso informativo: a cor caracteriza a marca com a intenção primeira de informar sobre ela, instaurar sua identidade, manifestá-la em sua totalidade, se tornando sinônima da marca que designa. Quando adequadamente informativo, esse discurso cromático atinge uma quaseautonomia da cor e chega a dispensar, em algumas situações, um elemento de identificação verbal (nome ou slogan de marca) ou outro elemento visual (logotipo, mascote, etc.). O azulesverdeado em uma caixinha de joia com um laço branco, o vermelho saturado na sola de um sapato, o laranja aplicado em mobiliário urbano e em propaganda, no Brasil, são exemplos icônicos desse discurso, identificando as marcas Tiffany, Louboutin e Itaú, respectivamente. 
Discurso (1) da Cor-Assinatura: Tiffany, em discurso designativo-informativo.

(a)

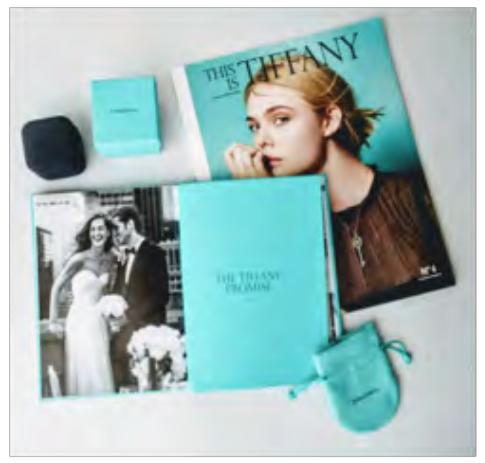

(d)
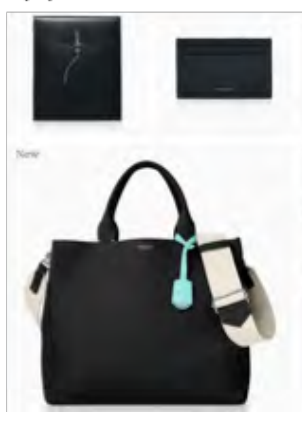

(b)

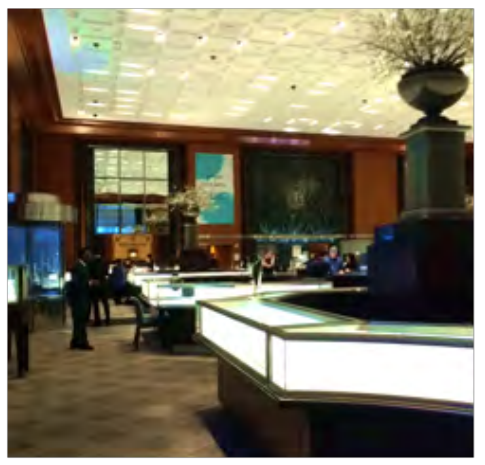

(e)

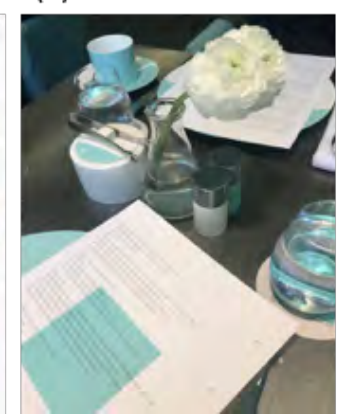

(c)

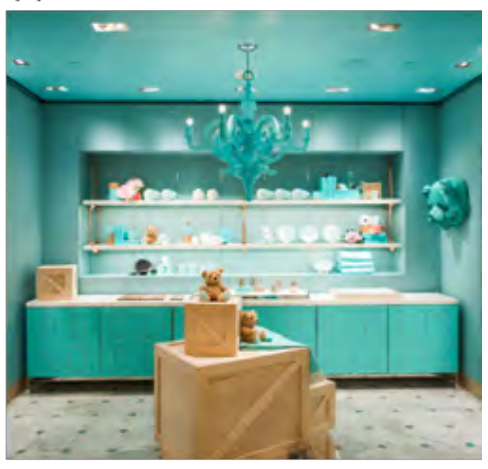

(f)

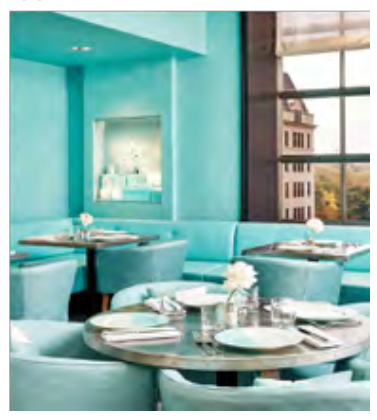

Marca: Tiffany \& Co.

Cor: azul Tiffany, Tiffany blue (ribbon's egg blue), Pantone 1837.

\section{Pontos-de-contato analisados}

(a) Embalagens e material colateral; (b) Ambientação tradicional da loja-conceito em Nova York, $1^{\circ}$ andar, (c) Novo ambiente da loja-conceito NYC, $4^{\circ}$ andar; (d) Produtos no site-loja virtual; (e, f) Ambiente de ativação de marca (Blue Box Cafe).

\section{Modo proeminente de significação da cor: DESIGNATIVO}

- Opera na caracterização da marca, fixa e consistentemente em todos os pontos de contato possíveis. Atenção aos acessórios de couro (d): além do azul patenteado, as únicas outras cores disponíveis são acromáticas (branco, preto e cinzas) ou em baixa saturação (marrom).

\section{Uso principal do signo-cor: INFORMATIVO}

- Informa a identidade quase autonomamente: cor patenteada, embalagem patenteada (blue box), Pantone definido e exclusivo (numerado em homenagem ao ano de fundação).

Fontes: (a) Acervo da pesquisadora; (b) Visita de observação; (c) Jornal The New York Times (Schneier, 2017); (d) Site oficial (Tiffany \& Co, 2018); (e, f) Postagens no portal Yelp, por um visitante e pela Tiffany, disponíveis em <www.yelp.com/biz/the-blue-box-cafe-new-york>. Último acesso em 10/01/2018.

O tipo discursivo da cor-assinatura é inspirado em seu discurso equivalente na tipologia de Morris: o discurso "científico" (1946, pp. 126-128). Nele, o signo opera no modo 
mais adequado para informar algo que existiu, existe ou existirá, uma vez que não aprova ou desaprova, nem comanda qualquer ato: baseado em evidências, ele descreve, elabora e refina declarações generalizáveis, consistentes, a serem confirmadas ou desconfirmadas. "Em um nível baixo de evidência, as declarações são chamadas de hipóteses, enquanto as mais confirmadas são leis, que formam a base de sistematização da ciência” (1946, p. 127).

Analogamente, para explorar a cor como sua assinatura confirmatória, a marca pode e deve patenteá-la (um registro legal), garantido seu uso exclusivo dentro da categoria. Assim como o "discurso científico é especialmente interessado pela busca de signos confiáveis" (Morris, 1946, p. 127), a cor-assinatura deve ser usada imutavelmente e com consistência em todos os pontos de contato, ao logo do tempo, para obter os resultados comunicativos desejados.

Se você conhece a Owens Corning, você sabe que nós desenvolvemos isolamento de fibra de vidro, e que somos muito conhecidos pelo isolamento rosa. Fomos a primeira empresa a patentear uma cor em 1987... Na época, queríamos diferenciar nosso produto no mercado, e tornou-se tão aceito e bem conhecido, que o rosa está [hoje] fortemente associado a isolamento termoacústico. Ao longo da nossa história, patenteamos o rosa, temos produtos cor-de-rosa e a Pantera Cor-de-Rosa faz parte da nossa marca....

Faz sentido para o negócio aproveitar essa cor no mercado, porque isso nos diferencia. Consumidores, clientes, eles identificam o rosa como um produto premium ou como qualidade. (Depoimento de especialista - Owens Corning)

\section{A Cor-Mito (discurso cromático apreciativo-informativo)}

O cruzamento do modo apreciativo com o uso informativo configura o discurso da cormito, análogo ao discurso "mítico", conforme ilustrou Morris. Segundo ele, esse tipo discursivo aprecia ou desaprecia certas coisas/ações para alguém ou para um grupo, com o objetivo principal de fornecer informações de acordo com o gosto ou preferência desse alguém (ou grupo) em relação a essas coisas/ações. Uma mitologia informa os intérpretes, intensamente, sobre os jeitos de agir, aprovados ou reprovados pela sociedade - informação que eles podem, concordando ou descordando, aplicar ou refutar em suas próprias vidas (Morris, 1946, pp. 134-136).

Similarmente, as marcas emitem o discurso da cor como mito carregando suas cores com qualidades arquétipas, com personalidade ou superpoderes, como se fossem um encantamento mágico e eterno. Um signo mítico, como o mythos da Grécia antiga, faz uma 
narrativa poética e legendária, por fragmentos de estórias com dimensão metafórica (Santaella \& Nöth, 2009, p. 35). Esse é o caso do azul, a cor principal do varejista Walmart (2009), que "sugere autoridade, dignidade, segurança, estabilidade, patrimônio e confiança"; do roxo dos colchões e acessórios para dormir da Purple (2016), "que é uma cor fantástica e significa tratar todo mundo como realeza"; ou dos poderes mágicos das cores na lingerie das brasileiras, como discursou a Valisere (2015) no réveillon 2015/2016.

Esse discurso pode ser emitido mesmo sem o apoio direto de signos verbais. Assim é o exemplo da cor volt, discurso da cor-mito da Nike - marca cujo o nome refere-se à deusa alada da vitória, da mitologia grega (Nike, 2018). Ao aplicar a volt nos tênis dos atletas de ponta, nas Olimpíadas de Londres, a cor hoje é sinônimo da velocidade, alta performance e do triunfo dos deuses do esporte.

\section{Discurso (2) da Cor-Mito: M\&M's, em discurso apreciativo-informativo.}

(a)
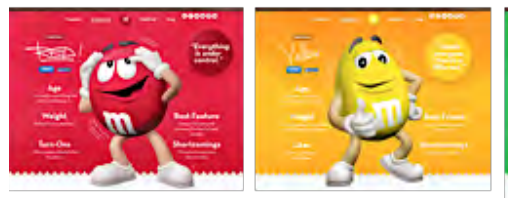

(b)
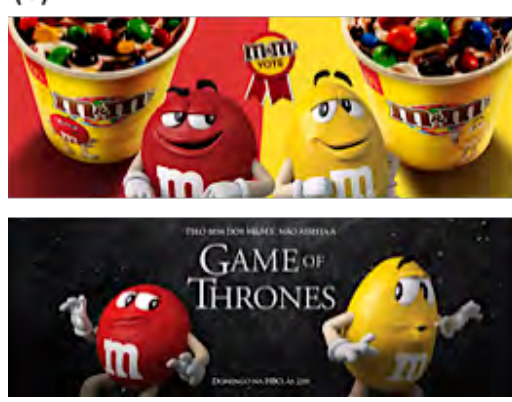
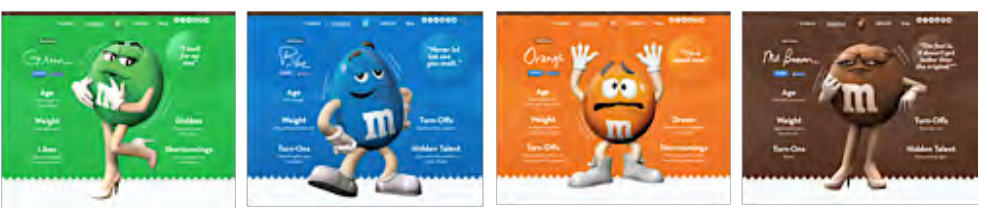

(c)
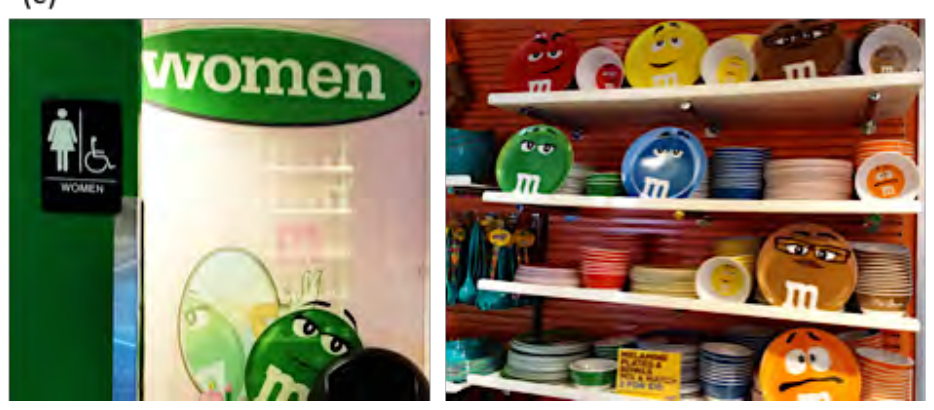

Marca: M\&M's.

Cores: vermelho, amarelo, verde, azul, laranja, marrom.

\section{Pontos-de-contato analisados}

(a) Site da marca; (b) Perfil do Facebook, M\&M's Brasil; (c) Loja conceito em Nova York.

\section{Modo proeminente de significação das cores: APRECIATIVO}

- Cada cor-personagem é carregada de características humanas, pontos fortes e fracos, preferências e antipatias, em uma antropomorfização bem-humorada, emocional.

- As cores-mito são nomeadas e caracterizadas positivamente pelas cores (a), vivem e interagem com os fãs pelo Facebook (b), são parte fundamental da ambientação da loja conceito (c) e são os mais caros produtos vendidos (o que não é chocolate ou comestível). 


\section{Uso principal do signo-cor: INFORMATIVO}

- Informa os públicos sobre:

- a identidade visual (multi-colorida) e a personalidade da marca (divertida e humana, com os traços típicos de cada cor).

- os diferentes tipos de confeito oferecidos (chocolate ao leite, recheio de amendoim, crispy, chocolate meio-amargo, etc.), porém não relacionados especificamente como uma cor.

- em linguagem de desenho animado, o perfil do consumidor-alvo: jovens de todas as idades.

Fontes: (a) Site americano (M\&M's, 2016) ; (b) Perfil oficial brasileiro no Facebook /MMSBrasil>;

(c) Visita de observação. Último acesso em 10/01/2018.

O discurso da cor-mito foi verificado repetidamente na prática dos criadores e comunicadores entrevistados, como "estória da cor" (color story): qualidades expressivas que a cor revela, narra ou transmite para as marcas que a utilizam, propriedades essas que são apreciadas e/ou cobiçadas pelos indivíduos-consumidores. Os mitos podem basear-se nas associações cromáticas já estipuladas culturalmente ou serem totalmente criados por uma marca, por meio da publicidade.

Quando penso em cores, penso na estória da cor [color story], que tipo de narrativa estou tentando criar para a marca, como a cor reforça a narrativa em todas as suas aplicações, desde o produto até o logo, como vai ficar na rua, no prédio da sede corporativa... nos lugares que você passa todos os dias. Qual é a estória das cores que você deseja que as pessoas sintam quando entrarem em contato com a marca? Assim, cada ponto-de-contato tem um tipo diferente de ressonância, como um personagem diferente que deve ser adicionado à narrativa da marca.

...

Entender os contextos culturais diferentes e como isso afeta de forma positiva e negativa a sua narrativa e a sua estória de cor, é super importante quando você for decidir as cores da marca. (Depoimento de especialista - Frog Design)

\section{O Manual-da-Cor (discurso cromático prescritivo-informativo)}

Toda marca deve ter um livro de marca (brand book) que sintetize sua cultura, valores, crenças, personalidade e comportamento, configurando a plataforma ou ideia central sob a qual um produto, serviço, corporação, etc. são concebidos e regidos. Como parte desse livro, tem-se o "guia de expressão de marca", também denominado de "manual de linguagem 
de marca" ou "manual de aplicação" de marca. Nele, entre outras coisas, é especificada a estética visual marcária: as cores, as fontes tipográficas, as variações permitidas do logotipo, mascote, símbolos gráficos, o estilo das fotografias, ilustrações e diagramações. Via de regra, as marcas dedicam páginas desses manuais para especificar tecnicamente as cores principais e secundárias, como e onde aplicá-las e combiná-las, realizando assim o discurso do tipo "manual-da-cor": informar como se deve utilizar as cores marcárias.

O discurso do manual-da-cor, aqui proposto, ocorre no encontro do modo prescritivo com o uso informativo, tipificado por Morris como discurso "tecnológico" (1946, pp. 143-145): um prescritor de ações, com técnicas e receitas, no intuito de informar os intérpretes sobre como alcançar certos objetivos.

Discurso (3) do Manual-da-Cor: Heineken, em discurso prescritivo-informativo.
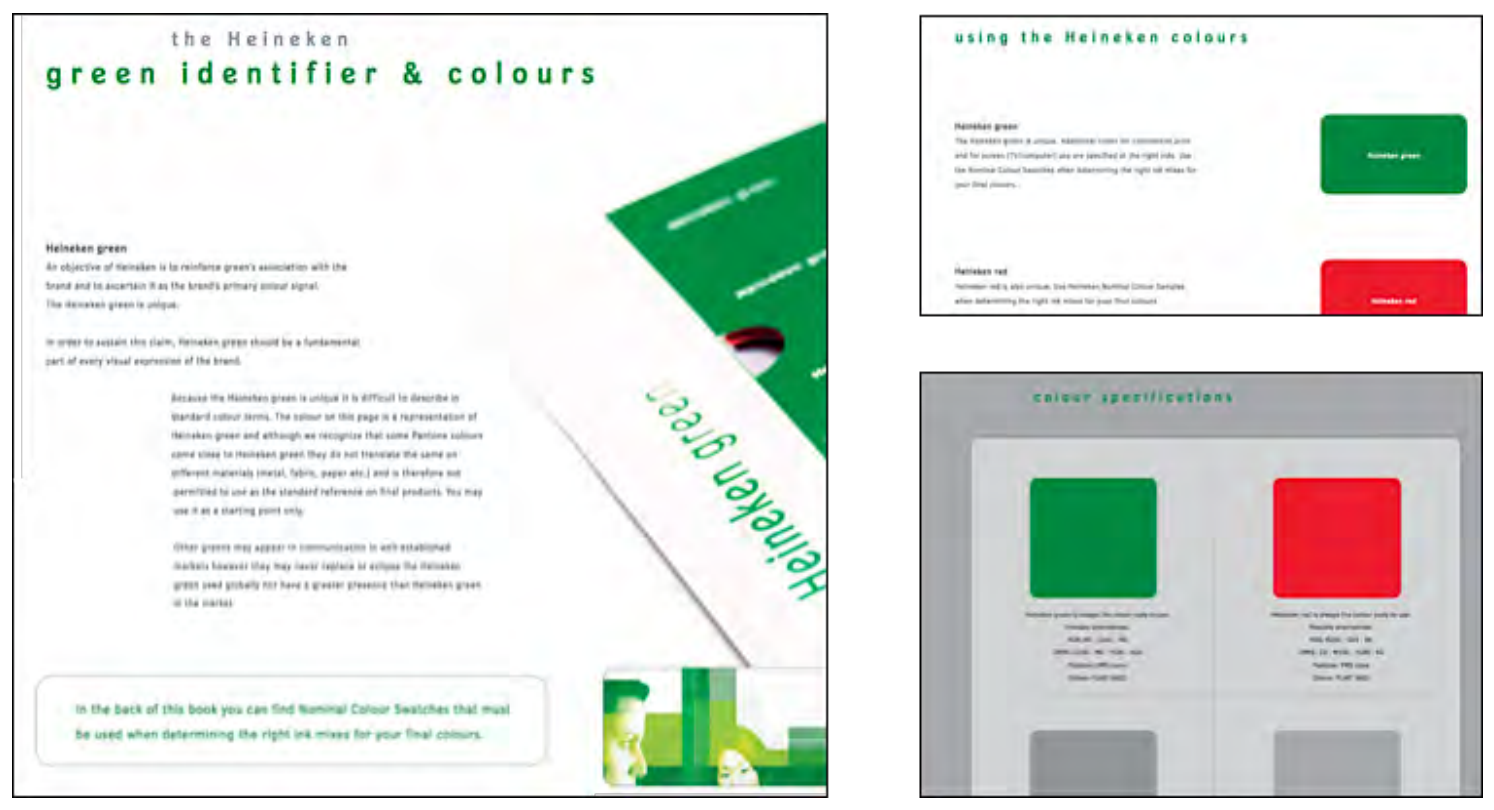

Marca: Heineken.

Cores: Verde, vermelho, cinza e prata.

\section{Ponto-de-contato analisado}

(a) Guia de identidade visual da marca.

\section{Modo proeminente de significação das cores: PRESCRITIVO}

- Prescreve uma ação para a marca: "O verde Heineken é único. A fim de sustentar esta alegação, o verde Heineken deve ser uma parte fundamental de toda a expressão visual da marca.... Na parte de trás do guia, você encontra amostra das cores que devem ser usadas nas misturas de tintas para a obtenção das cores finais corretas". 


\section{Uso principal do signo-cor: INFORMATIVO}

- Informa as cores da marca nos sistemas: "O verde Heineken é a cor especial a ser usada.

Possíveis alternativas: RGB: R0, G161, B0; CMYK: C100, M0, Y100, K24; Pantone: nenhum”.

Fonte: Guia de identidade visual da Heineken (2005, pp. 30-33).

Esses manuais de marca não são pensados para os consumidores, mas frequentemente caem na rede (internet) e são visualizados, colecionados e discutidos pelo público geral. Originalmente, os guias são confidenciais, restritos a funcionários, colaboradores e fornecedores contratados pelas marcas.

Assim como o discurso tecnológico de Morris, o discurso do manual-da-cor não tem como função primeira apreciar as regras que prescreve, nem incitar os públicos a realizá-los, embora isso ocorra em um segundo nível de importância. Esse discurso primordialmente informa o que já é tido como desejado e acionado (Morris, 1946, p. 143). Afinal, é de se esperar que os criadores e produtores dos materiais queiram agir e que ajam conforme o que estipula o manual-da-cor, para que as peças de comunicação e ativações marcárias colaborem na constituição de uma marca única, diferente das demais.

Definimos o marrom e o espectro de cores da UPS, não apenas o marrom. É inacreditável, antes havia toneladas de marrons. Eles ainda têm vários, por exemplo, por causa da lavagem industrial dos uniformes, que não podem ser escuros. E possuir o marrom é muito distintivo e reconhecivel, poucas empresas usam o marrom, nem conheço outra. Criamos um livro de cores para a UPS, com os diferentes mecanismos e técnicas de impressão. Usando Pantone, hexachrome, CMYK, ... traduzindo tudo de maneira proprietária. Quanto mais singular for a sua cor, mais você tem que se certificar que todas as impressões, on-line, digital, serão fieis à cor. $\ldots$

Se você é uma marca global, eu acredito que é uma desvantagem não ter uma filosofia sobre as cores e sobre como lidar com as cores, personalizando por região, um pouco. Mas, primeiro, você precisa ter uma ideia sobre o que é [a marca] e então traduzir essa ideia globalmente, não aleatoriamente. (Depoimento de especialista FutureBrand) 


\section{A Cor-Disruptiva \\ (discurso cromático transformativo-informativo)}

No discurso da "cor-disruptiva", o signo-cor informa a identidade de marca para os públicos por meio de uma mudança na sua paleta cromática ou por utilizar cores até então não usadas na categoria. O modo transformativo, conforme discutido no capítulo 2, não é um tipo diferente de resposta comportamental - como são os modos designativo, o apreciativo e o prescritivo. Mas, por alterar os sentidos cromáticos de marca preestabelecidos, configura-se como um modo de ressignificação e caracteriza tipos discursivos cromáticos específicos.

Nos casos de reposicionamento de marca com mudança das cores identificativas, o discurso cromático disruptivo ocorre a partir do logotipo e se estende para as demais materializações, como propaganda, hotsite, press-release, etc. O objetivo é reestabelecer a identidade cromática junto ao público, acostumado com a marca em outra cor, e minimizar eventuais confusões iniciais. Exemplos de rebranding com mudança de cor são a Companhia Vale do Rio Doce, do preto para o verde-e-amarelo (em 2010); a Cabify, do preto e amarelo, para o roxo (em 2017); a Brastemp para o laranja e a Consul para o verde (ano 2000), ambas anteriormente azuis; e o McDonald's da Europa, de amarelo e vermelho para amarelo e verdeescuro (Associated Press, 2009).

Uma marca também realiza o discurso da cor-disruptiva ao utilizar cores diferentes, ou de uma maneira diferente, de todas as marcas da categoria. A disrupção no logotipo, nos produtos e embalagens, identifica, distingue e posiciona a marca como inovadora. Uma vez introduzida na marca (ou na categoria), se a inicial disrupção é assimilada, a cor pode ser explorada no discurso da cor-assinatura - principalmente se for patenteada, exclusiva da marca, identificando-a fixamente e consistentemente em todos os pontos de contato.

Olhamos quais são os códigos antigos, residuais, ... o que estão dominantes na categoria, e quais são os novos códigos, dos novos entrantes ou de marcas que estão começando a trazer novas linguagens para a categoria. A gente vai plotando tudo isso de uma forma analítica, inclusive com um círculo cromático, para identificar aonde estão as oportunidades. No caso do Nubank fazia sentido trabalhar o roxo por uma questão contextual, mas fazia mais sentido ainda porque ninguém ocupou aquele território. E como o propósito da marca era ser disruptivo, ela tinha que ser disruptiva em relação a categoria também, inovar na cor era uma necessidade. E aí a gente trouxe o roxo. (Depoimento de especialista - Epigram Brand Union) 
Discurso (4) da Cor-Disruptiva: Renova, em discurso transformativo-informativo.

(a)

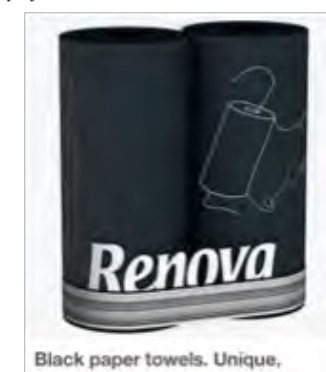

(c)

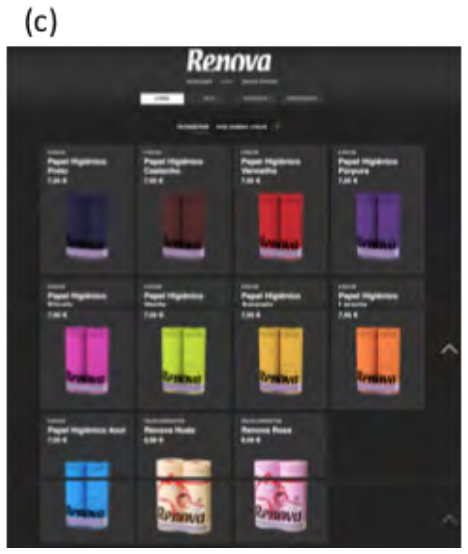

(b)

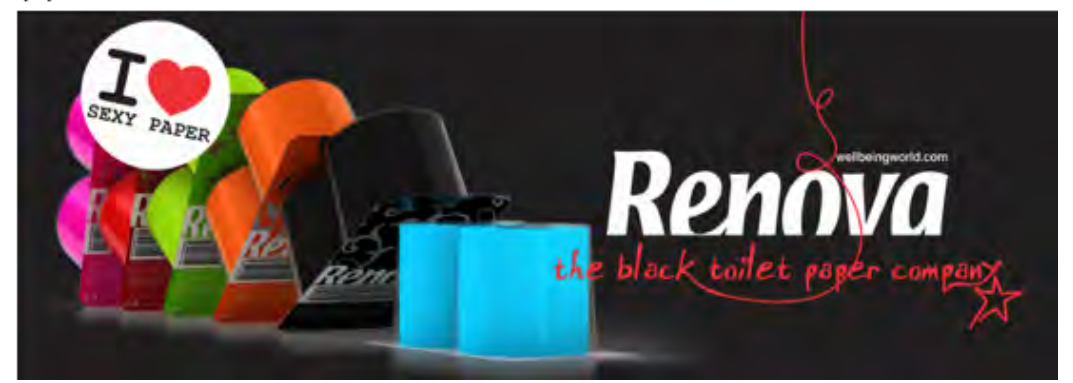

(b - continuação)

Marca: Renova, com a linha de papel higiênicos.

Cores: preto e mais 10 cores, além dos tradicionais brancos lisos ou decorados.

\section{Pontos-de-contato analisados}

(a) Conta oficial do Pinterest; (b) Conta oficial no Flickr; (c) site/loja virtual da marca.

\section{Modo proeminente de significação das cores: TRANSFORMATIVO}

- As cores saturadas e/ou escuras são incomuns em papel higiênico. Causa estranhamento e custa mais caro que a versão branca (que a empresa também fabrica, assim como coloridos guardanapos, papel-rolo de cozinha, lenços de bolso e "serpentinas gigantes" (decoração).

- Pelo caráter diferente e premium do papel, as lojas pop-up (b - continuação) são instaladas em shoppings e aeroportos, locais nada usuais para um produto geralmente vendido em mercados e farmácias.

\section{Uso principal do signo-cor: INFORMATIVO}

- A inovação na cor é a característica principal da marca, conhecida como (b) "a companhia do papel higiênico preto", que ela inventou e lançou nos anos 2000.

Fontes: (a) Conta no Pinterest < https://br.pinterest.com/wellbeingworld/products-we-love/ >; (b) no Flickr < www.flickr.com/photos/renova/>; (c) Site oficial (Renova, 2017). Último acesso em 10/01/2018.

Morris exemplificou a interação do modo formativo com o uso informativo como discurso "lógico-matemático" (1946, pp. 168-171). O autor considera que os discursos no modo formativo são difíceis de serem distinguidos, sutis e arbitrárias que são as diferenças 
discursivas que apresentam. Porém, o discurso "lógico-matemático" seria o de menos difícil exemplificação: "Se homens são animais e animais são mortais, então homens são mortais" ou “2+2=4” (Morris, 1946, p. 169).

A descrição de discurso lógico-matemático Morrisiano não se encaixa na tipologia cromática aqui proposta, uma vez que o modo formativo (apropriado para signos linguísticos) foi adaptado para o modo transformativo do signo-cor, nesta tese. Isso irá se repetir nos demais discursos no modo transformativo de significação (cor-dialógica e cor-criação).

\subsection{Os discursos cromáticos para preferência de marca}

Discursos cromáticos para a preferência de marca são aqueles cuja a principal função é provocar uma avaliação positiva da marca junto aos públicos de interesse, nos quais a cor opera no modo designativo, apreciativo, prescritivo ou transformativo (Quadro 4.4).

Quadro 4.4: Os quatro tipos de discursos voltados para a preferência de marca.

\begin{tabular}{|c|c|}
\hline MODO & USO AVALIATIVO DO SIGNO-COR \\
\hline DESIGNATIVO & Arco-Íris (discurso marcário designativo-avaliativo) \\
\hline APRECIATIVO & Cor-Alegoria (discurso marcário apreciativo-avaliativo) \\
\hline PRESCRITIVO & Cor-do-Ano (discurso marcário prescritivo-avaliativo) \\
\hline TRANSFORMATIVO & Cor-Dialógica (discurso marcário transformativo-avaliativo) \\
\hline
\end{tabular}

Fonte: Desenvolvido pela autora.

Esses discursos ocorrem, por exemplo, quando a cor é aplicada nos elementos visuais do mix de identidade da marca sem a incumbência de identificar a marca - como nos casos de marcas mutantes na cor. Campanhas institucionais corporativas ou conceituais de marca, que não têm a função primeira e direta de provocar compra ou outra ação de engajamento, também são exemplos: patrocínios de causas sociais (e.g. outubro rosa), eleição da cor do ano, e adaptações das cores originais da marca a fim de agradar. Aqui, a dimensão simbólica incorpora fortemente a dimensão estética-sensível e revela seu caráter efêmero, de "espírito do tempo" - o que é positivo/belo/preferido/relevante hoje, pode não o ser amanhã. O que é aqui, pode não ser, lá. 


\title{
O Arco-Íris (discurso cromático designativo-avaliativo)
}

O discurso cromático do "arco-íris" é realizado com cores caracterizadoras cujo objetivo primordial é causar emoções e julgamentos positivos, enquanto a função informativa da identidade marcária fica em segundo plano. Nele, a marca explora uma vasta gama de cores (no logotipo, na embalagem, nos produtos, etc.) para agradar e conquistar o maior número de pessoas possível, sem se fixar ou se identificar com nenhuma cor, obrigatoriamente. Não existe cor melhor ou pior, positiva ou negativa, elas simplesmente existem e colorem o mundo, um mundo marcário ideal.

\begin{abstract}
Aqui é como o oceano azul e nuvens escuras acima.... Essa prateleira aqui, para mim, é como se rosas e roxos estivessem de mãos dadas.... Essa prateleira aqui embaixo é a cozinha da minha mãe, ela sempre teve azuis e amarelos na cozinha. E meu chefe dizia: "você nunca vai conseguir juntar azul e amarelo em uma combinação"... e eu disse: "Vai funcionar e será muito popular".... E aqui, meus verdes terrosos até os marrons e flores laranjas e vermelhas... e aqui meus tons de praia, meus azuis-água e violetas. (Depoimento de especialista - Glassybaby)
\end{abstract}

Enquanto no discurso designativo-informativo a cor é a assinatura identificadora marcária, no discurso do arco-íris (designativo-avaliativo) o público se identifica com a marca, pela cor.

Muitas pessoas nem me dizem qual a cor preferida. Eu pergunto: "Qual é a cor de destaque da sua decoração" e "Você tem medo de cores fortes para combinar?", "Você quer algo mais discreto?", "Uma cor como assinatura pessoal?".... Eu ajudo as pessoas a descobrirem o que estão procurando....

Eu quero que as pessoas fiquem felizes... tanto quanto eu, aqui. Honestamente, é o que é, fazer alguém feliz quando levam [o produto] para suas casas ou presenteiam alguém. Eles precisam ser especiais, eu sinto isso. (Depoimento de especialista - Glassybaby)

O discurso do arco-íris é proferido pelas marcas mutantes na cor, designadas por um número ilimitado ou pré-determinado de combinações de cor (as brasileiras Oi e Vivo, por exemplo), incluindo as marcas que se identificam "acromaticamente" com logos oficiais em preto, branco ou cinza, mas que aplicam alternadas cores em seus elementos identitários, conforme o contexto (frequente nas categorias de moda e de luxo). É o caso também das marcas que exploram várias cores em seus produtos como diferencial expressivo e competitivo: as 
cápsulas da Nespresso e os papéis-higiênicos da Renova (onde a marca portuguesa atua há anos, os consumidores já se habituaram com rolos coloridos e o efeito transformativo foi superado).

Discurso (5) do Arco-Íris: Telstra, em discurso designativo-avaliativo.

(a)

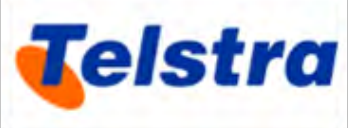

(b)

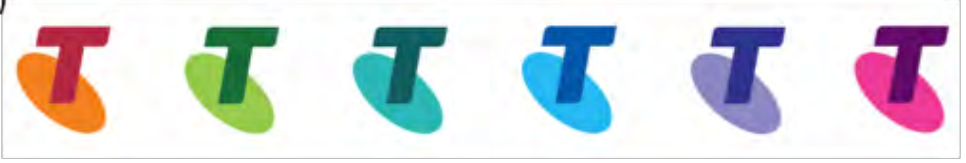

(c)

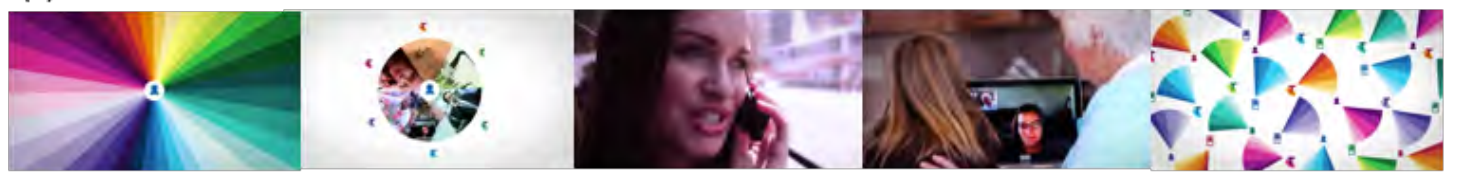

(d)

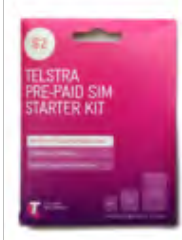

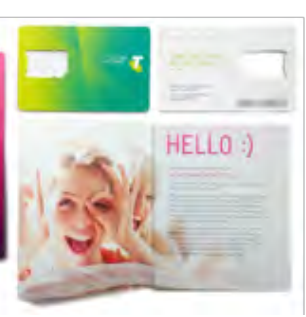

(e)

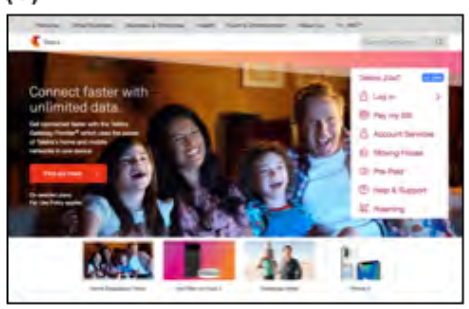

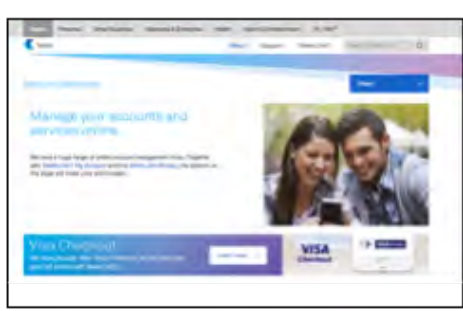

Marca: Telstra (marca de telecomunicações da Austrália).

Cores: 6 opções (identidade mutante na cor), cada uma com 2 tons do mesmo matiz.

\section{Pontos-de-contato analisados}

(a) Logotipo antigo (até 2011); (b) Logotipos atuais; (c) Frames de vídeo-institucional (2011);

(d) Kit pré-pago (2016); (e) Interface do site atual.

\section{Modo proeminente de significação das cores: DESIGNATIVO}

- Nos materiais, diferentes cores e pessoas (em diversidade racial, de gênero, idade, etc.): (c) "... agora vivemos em cores, porque sabemos que você vive". Locução e imagens que, ao descreverem a marca, a iguala ao seu consumidor plural: uma marca com diversas cores para diferentes gêneros, idades, etc.

\section{Uso principal do signo-cor: AVALIATIVO}

- Um ano após o rebranding (Welcome to life in full-colour), o CMO da empresa explicou que "a nova identidade colorida... foi projetada para criar uma conexão mais forte e emocional entre a Telstra e clientes.... Em 2010, a empresa era percebida como arrogante e indiferente" (Telstra, 2012).

- Com o fim do monopólio estatal do setor na Austrália, a Telstra precisou voltar a ser uma marca admirada, preferida e escolhida pelos australianos, que passaram a ter outras opções de prestadora de serviço. 
- A função avaliativa da cor (e de outros signos na campanha) é evidenciada na valência positiva: (c) “... para poder conectá-lo com as coisas... que você ama, de maneira melhor do que nunca antes".

- Texto e música referindo-se às cores (vivas, saturadas) como signo de diversidade, de conexão, de amor e de alegria, em um tom emotivo e superlativo. Em 2012, a marca já tinha seu índice de consideração de compra aumentado em $5 \%$.

Fontes: (a, b) Blog Brand New (Vit, 2011); (c) Vídeo-case Interbrand (2011) (d) Acervo da pesquisadora; (e) Site da marca (Telstra, 2018).

Morris, pensando em signos verbais, ilustra o discurso designativo-avaliativo como "fictício" (1946, pp. 128-130): narrativas emocionantes e cativantes que exploram universos imaginários, feitas para agradar e serem percebidas como relevantes, mesmo sem delinear o mundo ou situações como são "de fato". A eficácia (adequação avaliativa) dessas utopias depende de os leitores acreditarem que a situação descrita é possível e provável de acontecer; de proporcionarem (com suas designações fictícias) uma satisfação simbólica aos leitores, confirmando os sonhos e temores que eles têm sobre a vida que poderia ser vivida. Quanto mais distantes ou incompatíveis com a sociedade real, mais fantásticas - e com o passar do tempo, mais absurdas - as ficções parecem ser (1946, p. 130).

Similarmente, o discurso do arco-íris remete o consumidor a um mundo fantástico, onde todos encontram suas cores preferidas - cores estipuladas pela marca, mas que combinam com sonhos e universos particulares, em uma apropriação (posse literal ou simbólica) que os levam até pote-de-ouro da felicidade. Um mundo colorido que abriga todas as aspirações.

\section{A Cor-Alegoria (discurso cromático apreciativo-avaliativo)}

No discurso da "cor-alegoria", a marca explora as cores metaforicamente para denotar coisas, ideias e ações valorizadas socialmente e, assim, ligar-se a essas avaliações positivas. Para que o discurso da cor-alegoria seja adequado - considerando as inúmeras associações, paradoxais e estereotipadas, estabelecidas entre cores e valores culturais - a marca deve evidenciar qual a metáfora cromática que pretende atualizar na mente interpretante, o que geralmente faz com o apoio de outros signos visuais e verbais.

Por exemplo, o vermelho é a cor da paixão, do desejo e da vida, mas é também a cor do perigo, da morte, da dívida financeira. $\mathrm{O}$ arco-íris pode ser um signo infantil, ou remeter à 
comunidade LGBT (PQIA+), seu orgulho e movimentos por direitos iguais. Os tons amarronzados podem remeter à tradição e à força da terra e da madeira, mas também à diversidade racial e da luta contra o racismo. $\mathrm{O}$ verde pode ser a cor da esperança, do dinheiro (dólares!), da natureza, mas também o "verde de inveja" ou o "verde de fome".

\section{Discurso (6) da Cor-Alegoria: Skol, em discurso apreciativo-avaliativo.}

(a)

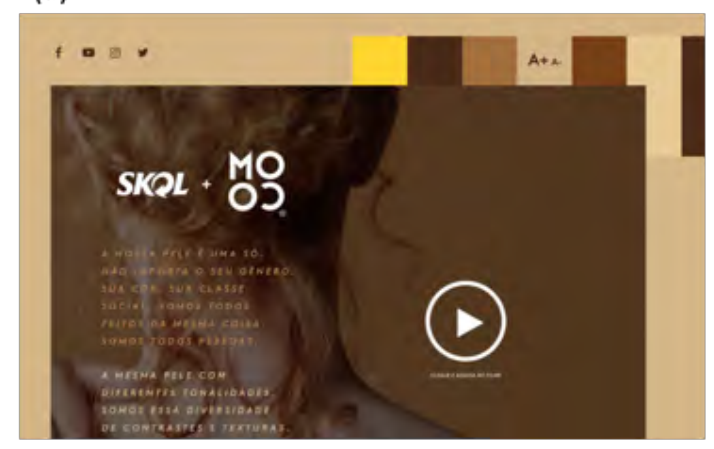

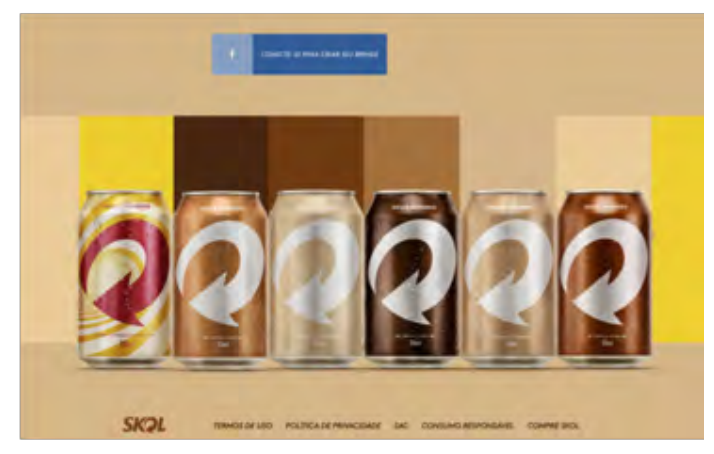

(b)
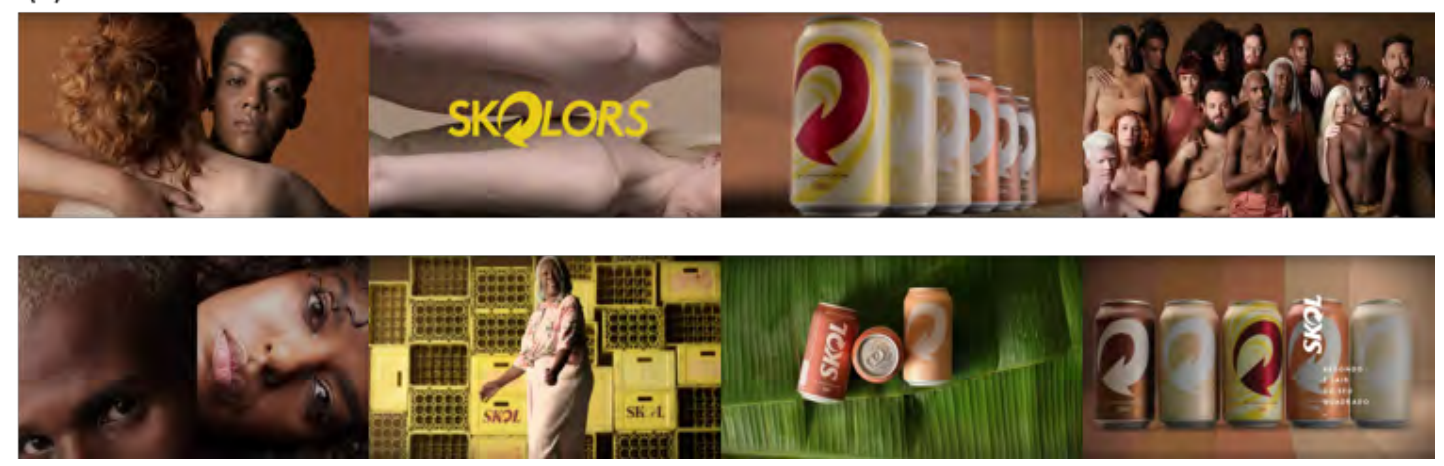

Marca: Skol, em edição especial e limitada, Skolors.

Cores: amarelo original da marca e mais 5 "tons de pele".

\section{Pontos-de-contato analisados}

(a) Site oficial; (b) Vídeo-conceito; (c) Post original da marca Skol, no Facebook, do dia 10 de abril de 2017 (imagem não reproduzida aqui).

Modo proeminente de significação das cores: APRECIATIVO (transformativo em menor grau)

- Na edição especial, as "cores-de-pele" são carregadas de um aspecto considerado central e positivo na sociedade atual - a luta contra o racismo.

- A Skol, amarela com tipografia vermelha, minimiza o efeito transformativo das (inusuais) cores de pele e maximiza o efeito apreciativo, por duas vias: 1) o amarelo identificativo está presente na campanha, no logo, no cenário, na embalagem; 2) criando uma submarca (Skol + colors). A Skol comunica que não transformou sua cerveja, mas estendeu a marca. 
- Ao usar o verde junto ao amarelo, valores positivos de brasilidade são acionados, junto com o ritmo brasileiro que mistura com a batida eletrônica (típica da Skol).

- O texto do site resume o modo apreciativo das cores, unindo Skol-Brasil-diversidade racial: (a) "A nossa pele é uma só. Não importa o seu gênero, sua cor.... Somos essa diversidade... Não importa sua pele, não importa a cor da lata, a essência é única e é de todos".

\section{Uso principal do signo-cor: AVALIATIVO}

- No texto é evidente o objetivo de provocar avaliações positivas, por meio da exaltação dos valores carregados nas cores: (a) "É essa a proposta do nosso projeto. É explorar a beleza dessa diversidade em todos os sentidos. É brindar às nossas diferenças".

- Acusada e auto avaliada negativamente como uma marca machista e preconceituosa (Prado, 2017), a Skol usa as cores estrategicamente em seu reposicionamento.

Fontes: (a, b) Site Skolors (Skol, 2017); (c) Perfil da marca no Facebook. Último acesso em 18/01/2018.

A maneira mais rápida (e menos onerosa) de discursar a cor-alegoria é explorando associações já estabelecidas entre cores e valores relevantes (e.g. verde-natureza, vermelhopaixão, rosa-feminilidade/juventude, etc.). Quando a marca pretender explorar uma associação exclusiva (entre ela, uma cor e um valor), terá que se dedicar à produção dessa associação, por exemplo, com o discurso da cor-mito - carregar as cores de poderes míticos positivos e vinculálos à identidade marcária.

O discurso cromático apreciativo-avaliativo é diretamente inspirado no discurso "poético" de Morris (1946, pp. 136-138), ele mesmo questionador se não seria mais um estilo do que um tipo discursivo, propriamente. Na tipologia original Morrisiana, o discurso poético é definido por seu objetivo de fazer o intérprete gostar (ou preferir) do que é comunicado como sendo positivo (e preferível), por linguagem metafórica.

\section{A Cor-do-Ano (discurso cromático prescritivo-avaliativo)}

A anunciação da "cor-do-ano" é realizada por inúmeras marcas, principalmente das categorias de beleza, moda e design (marcas de maquiagem, de material de construção, de decoração, vestuário, etc.). Esse discurso não ordena diretamente que comprem a cor prescrita, nem a marca que a utiliza: em primeiro lugar, a cor-do-ano visa a avaliação positiva da cor, para que também a marca seja admirada. Quando o discurso é adequado, a produtora discursiva é 
percebida como especialista em ditar o que os consumidores querem, uma definidora de tendência, uma marca-autoridade.

Quando colocamos nossas tendências, não estamos dizendo que elas são regras... estamos apenas dizendo, por nosso conhecimento, o que é importante no momento específico. E o mundo é tão grande agora, para o design! Há tantas culturas, tantas tendências... e a internet também está mudando as coisas.... Não há fronteiras em termos de cultura, o que torna as coisas mais difíceis de serem solucionadas... Mas eu nunca diria que existem regras... parece muito pesado dizer isso. (Depoimento de especialista - WGSN)

Os números mostram que revelar uma cor do ano não aumenta obrigatoriamente a venda da cor específica (ou do produto com a cor), mas incrementa o tráfego nas lojas e site das marcas, e indiretamente provoca um aumento nas vendas de todas as cores e produtos da marca (Stewart, 2017). A adequação discursiva depende da marca ser percebida como uma autoridade, ou suas prescrições cromáticas não serão efetivadas e, consequentemente, não obterão a avaliação positiva intencionada. Assim, é um discurso arriscado para marcas principiantes, desconhecidas, e para marcas em momento negativo, em desvalorização.

\section{Discurso (7) da Cor-do-Ano: Pantone, em discurso prescritivo-avaliativo.}

(a)

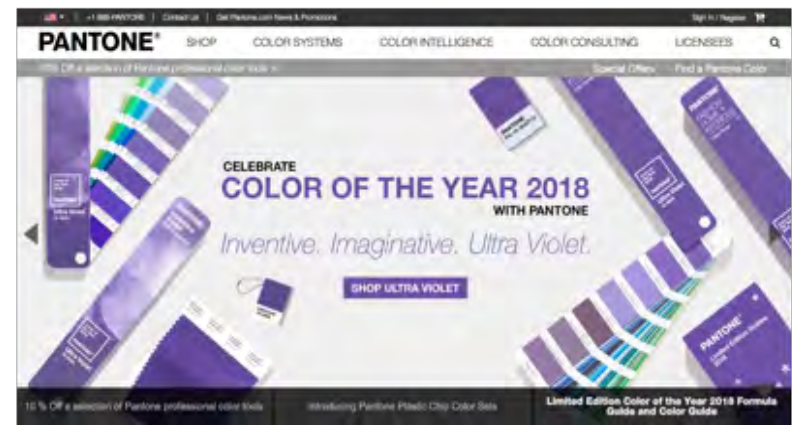

(b)

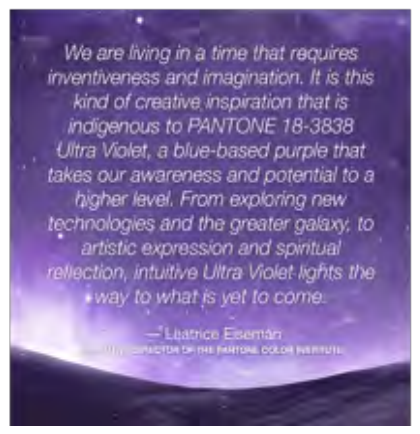

(c)

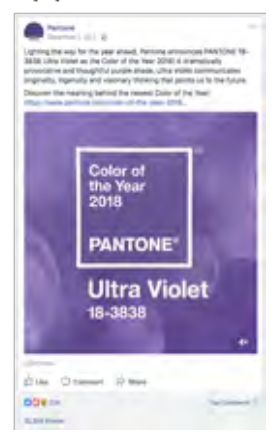

Marca: Pantone.

Cor: Ultra Violet 18-3838, a cor do ano de 2018, segundo a Pantone.

\section{Pontos-de-contato analisados}

(a) Site da Pantone; (b) Páginas do site dedicadas à cor do ano; (c) Post da revelação da cor no Facebook, em 7 de dezembro de 2017.

\section{Modo proeminente de significação da cor: PRESCRITIVO}

- A cor é prescrita para ser usada durante todo o ano: (b)“... os designers e as marcas devem se sentir capacitados para usar a cor para inspirar e influenciar". 


\section{Uso principal do signo-cor: AVALIATIVO}

- A justificação da prescrição da cor ocorre pela qualificação positiva: (a) "Inventiva.

Imaginativa”; (b) “... um roxo baseado o azul que leva nossa consciência e potencial para um nível mais alto".

- A intenção de transferir as avaliações positivas da cor para a marca é evidenciada no texto da vice-presidente do Pantone Color Institute, Leatrice Eiseman: (b) "... à medida em que os indivíduos ao redor do mundo ficam mais fascinados com a cor [...], refletindo o trabalho durante todo o ano do Instituto Pantone...".

Fontes: (a, b) site da Pantone (2017); (c) Perfil da marca no Facebook. Último acesso em 18/01/2018.

A cor de 2018, para a Pantone, é o ultra-violet, mas para a Owens Corning, a cor-doano é a "duna-de-areia", um bege claro levemente alaranjado (que tinge as telhas, de mesmo nome, da empresa), e para as tintas Coral é a "adorno rupestre", um cinza rosado. Essas marcas proclamam suas cores sem comandar ações do tipo "compre", nem expor links diretos para compra (não se trata de um discurso incitivo). Confirmando a natureza prescritiva-avaliativa do discurso, as webpages proeminentemente se dedicam a avaliar positivamente as cores, prescrevendo combinações cromáticas harmônicas: "Sand Dune é leve, arejada e muito acessível” (Owens Corning, 2017), “Adorno Rupestre pode ser combinado com tons terrosos para criar uma combinação de cores rica. Quebrar essas tonalidades quentes e harmonizadas com um toque de azul petróleo dá mais elegância ao aconchego...” (Tintas Coral, 2017).

As marcas de moda-luxo exploram esse discurso duas vezes ao ano, no lançamento da coleção de primavera-verão e de outono-inverno. Nos eventos, as Fashion Weeks, as marcasmaisons convidam celebridades e editoras de revistas especializadas, a fim de reforçar a relevância e provocar admiração pela marca (e suas cores eleitas). A partir da eleição da cor-doano (da estação), as marcas podem se empenhar em discursos da cor-da-moda (ver seção 4.3).

Morris apelidou essa conjunção do modo prescritivo com o uso avaliativo como discurso "político" (1946, pp. 145-146): a prescrição de ações que devem ser executadas, mas não diretamente incitando a sociedade à execução. O objetivo principal do discurso político é obter a aprovação dos valores e regras prescritas, por parte das instituições sociais que devem cumpri-las. Como exemplos, Morris cita o "Manifesto Comunista" de Marx, o "Contrato Social", de Rousseau e a "Declaração de Independência do Estados Unidos da América", explicando que essa última não incita a execução da ação, como seria em "trate todos os homens igualmente", mas qualifica positivamente o que prescreve: "todos os homens são criados iguais". 


\section{A Cor-Dialógica \\ (discurso cromático transformativo-avaliativo)}

O discurso da "cor-dialógica" é aquele onde o signo-cor opera no modo transformativo, por meio de uma cor diferente das marcárias habituais ou do código cromático da categoria, e que é produzido com o objetivo de gerar preferência para a marca. Assim, a cordialógica frequentemente contraria os discursos cromáticos informativos de identidade e outros discursos que estipulam valores ou regras, como o da cor-do-ano.

Coerência vs. consistência. É mais coerência, o escritório local explica o caso, e a matriz sabe que em um mundo global - sempre foi, mas percebem mais agora - você não pode impor....

Coerência significa que você sabe que existe uma variação, uma extensão, que pode acomodar o mercado global.

Existem os elementos-chave que você deve manter, certo? Mas, além disso, eles permitem uma inclusão. Por exemplo, a história da Kentucky Fried Chicken... a marca é vermelha, mas houve um caso na Austrália, uma festa, com as cores nacionais verde e amarela. Por um tempo, permitiram que as cores do país assumissem a marca completamente.... Interpretações com coerência, para acomodar o marketing local. (Depoimento de especialista - REBRAND ${ }^{\circledR}$ )

Discurso (8) da Cor-Dialógica: KFC, em discurso transformativo-avaliativo.

(a)

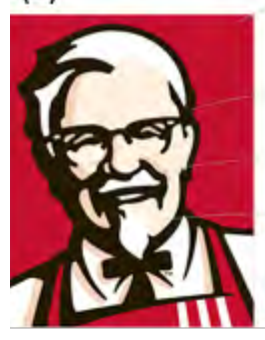

(d)

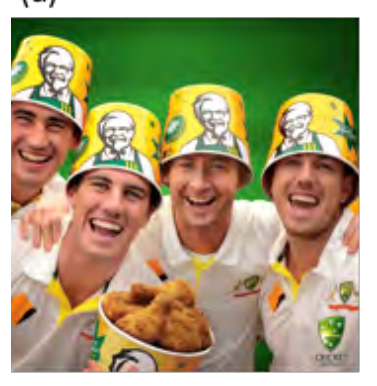

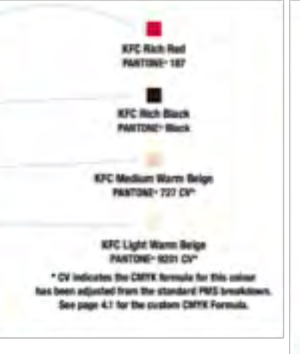

(b)

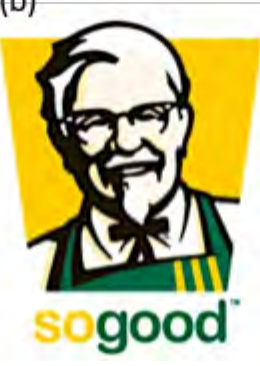

(c)

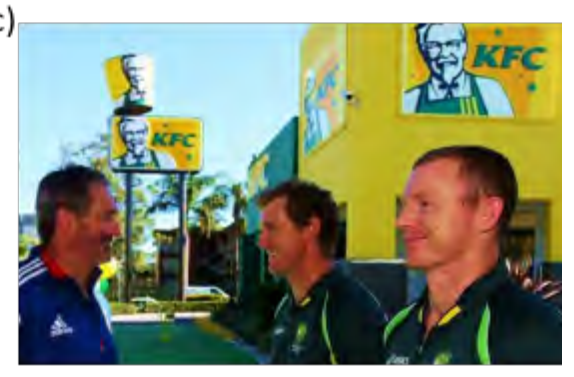

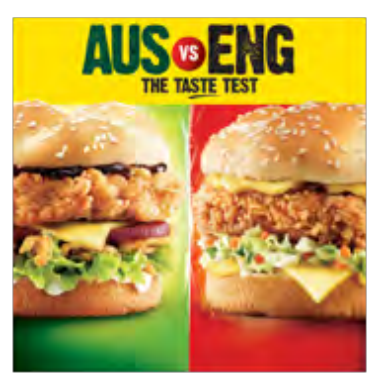
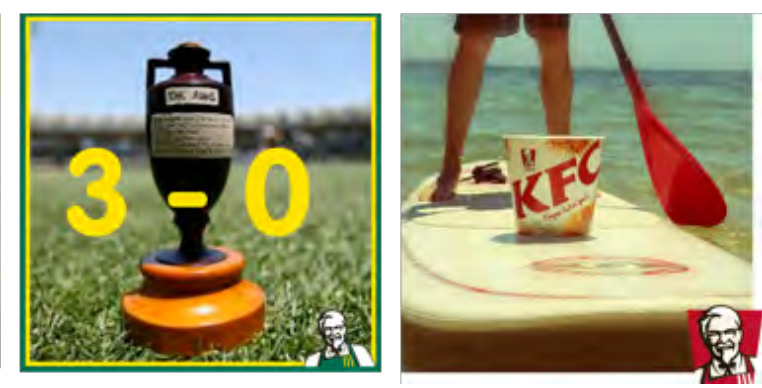

Marca: Kentucky Fried Chicken (KFC).

Cores: do vermelho identificador, para o verde e amarelo (Green \& Golden). 


\section{Pontos-de-contato analisados}

(a) Logotipo oficial da KFC; (b) Logotipo temporariamente e localmente alterado, nas cores; (c) Fotos da cobertura jornalística; (d) Postagens oficiais no Facebook entre novembro de $2013 \mathrm{e}$ fevereiro de 2014 (quando a ativação de marca foi encerrada).

\section{Modo proeminente de significação das cores: TRANSFORMATIVO}

- A KFC alterou totalmente suas cores identificadoras nas fachadas de lojas, uniformes de funcionários, nos famosos baldes de frango frito e em ativações de marca durante a período de jogo da seleção australiana de críquete, time que patrocinava havia 11 anos.

\section{Uso principal do signo-cor: AVALIATIVO}

- A mudança em apoio ao time australiano (cujo uniforme é verde e amarelo e que jogaria contra um forte time inglês, identificado com a cor vermelha) visou conquistar a preferência do consumidor local, torcedor do esporte.

- A partir do discurso dialógico, a marca lançou desafios para a torcida australiana pelas redes sociais, em subsequentes discursos cromáticos incitivos.

Fontes: (a) Manual de identidade (KFC, 2006); (b) Media release (Stead, 2013); (c) The Daily Telegraph (Smith, 2013); (d) Perfil KFCAustralia na Facebook . Último acesso em 18/01/2018.

Sempre quando uma marca adapta suas cores originais em função das demandas de seus consumidores, ela está discursando dialogicamente com eles, com a sociedade como um todo. Exemplos máximos são as marcas fortemente identificadas pela cor e que alteram suas cores durante um período ou em uma região específica, a fim de aumentar a relevância marcária ou anular rejeições, pela cor - caso da KFC na Austrália, da Coca-Cola e do Bradesco, em Parintins.

Casos onde a cor original é combinada com novas cores, mas permanece nas materializações, sem dúvida dialogam com seus públicos, mas estão sendo classificadas nesta tese como pertencentes a outra categoria discursiva, mais proeminente ou intensa (caso da Skolors, no discurso cor-alegoria, por exemplo).

Quando adequado, o discurso cromático dialógico cria ou reforça o vínculo entre marca e seus consumidores. Porém, a autenticidade é chave para o êxito dos discursos de uso avaliativo, em especial do transformativo-avaliativo. Justamente por não envolver uma cor e/ou um valor cultural comumente explorados pela marca, o discurso pode ser percebido negativamente como oportunismo em busca de avaliações positivas.

Na tipologia de Morris, o modo de significação formativo com o intuito de avaliar, configura o discurso "retórico" (1946, pp. 171-173), exemplificado por: "Crianças são crianças"; "Mulheres são mulheres"; "Uma boa vontade é boa em si” (referindo-se a Emmanuel 
Kant; "A natureza que esculpe a mudança é ruim" (referindo-se a Aristóteles) (Morris, 1946, p. 171). A descrição de discurso retórico Morrisiano, no qual o signo opera no modo formativo, não explica o discurso da cor-dialógica, onde o signo-cor opera no modo transformativo.

\subsection{Os discursos cromáticos para engajamento de marca}

Discursos cromáticos para o engajamento de marca, são aqueles onde a função principal da cor é incitar os públicos a ações, por qualquer um dos possíveis modos de significação (Quadro 4.5). Aqui estão incluídas as campanhas, eventos e ativações promocionais (promoção de venda), geralmente de curto prazo e projetadas para estimular a experimentação, compra, ou interação do público, ou neutralizar as ações da concorrência.

Quadro 4.5: Os quatro tipos de discursos voltados ao engajameto do público com a marca.

\begin{tabular}{|c|c|}
\hline MODO & USO INCITIVO DO SIGNO-COR \\
\hline DESIGNATIVO & Cor-Código (discurso marcário designativo-incitivo) \\
\hline APRECIATIVO & Cor-da-Moda (discurso marcário apreciativo-incitivo) \\
\hline PRESCRITIVO & Cor-Mania (discurso marcário prescritivo-incitivo) \\
\hline TRANSFORMATIVO & Cor-Criação (discurso marcário transformativo-incitivo) \\
\hline
\end{tabular}

Fonte: Desenvolvido pela autora.

Promoções que exploram as cores em brindes, sorteios e concursos, edições colecionáveis ou por tempo limitado, são classificadas como tipos discursivos cromáticos incitivos. Do mesmo modo, as comunicações de ponto-de-venda, físico ou online, geralmente discursam com o objetivo de provocar uma ação, principalmente a compra: material gráfico ou audiovisual decorativo/promocional, displays, e o próprio ambiente de compra em si - como as lojas-multimarcas (varejistas), lojas-conceito, sites de compras e aplicativos (de serviço de taxi, banco digital, cartão de crédito digital). Além disso, as postagens das marcas em seus perfis oficiais nas redes sociais e em blogs, também discursam incitivamente pela cor, visando obter uma interação com sues públicos, seja com likes e coraçõezinhos ou, em um nível mais alto de envolvimento, com comentários e compartilhamentos. 


\section{A Cor-Código}

(discurso cromático designativo-incitivo)

O discurso da "cor-código", no cruzamento do modo designativo com o uso incitivo, encoraja os públicos a se engajarem com a marca por meio de cores que designam características, personalidade, benefícios de quem as utiliza conforme a regra incitadora. $\mathrm{O}$ termo "código" é aqui pertinente nas suas acepções de "norma, regra, princípio"; de "sistema cifrado", ininteligível para os que não possuem a chave de decodificação; de elemento estabelecido para "representar, identificar e controlar os integrantes de um certo conjunto". 30

Para incitar situações e maneiras de usar marcas e suas cores, o discurso da corcódigo estabelece um pacto, um comprometimento entre a marca e sua comunidade, possuidora da chave de decodificação. O dress-code é o mais frequente exemplo de discurso cor-código: a marca promotora de um evento incita seu público a usar uma cor (geralmente a designadora marcária) durante um espetáculo patrocinado, um jogo de futebol, uma época do ano, etc.

As equipes esportivas baseiam-se muito na cor. É assim que você define quem está ganhando: é a equipe verde ou a equipe branca vencendo?... Tem um poder nisso.

\section{..}

Parte do engajamento da comunidade, a experiência fandom, é o conectar-se com outras pessoas, um vínculo. É uma ótima declaração visual em um ambiente esportivo, ter 70 mil pessoas vestindo a mesma [cor de] camisa. Faz parte da apresentação visual geral.... Nós contra vocês, camisas brancas $x$ camisas vermelhas... é assim que intuitivamente vemos nós contra eles. Fica ótimo na televisão, inspira as pessoas a se interessarem. É uma declaração bastante clara quando você tem um estádio inteiro de cem mil pessoas com a mesma cor de camisa. (Depoimento de especialista University of Oregon)

O mais polêmico (e inadequado) caso brasileiro de discurso da cor-código vem do âmbito das marcas políticas/pessoais: em agosto de 1992, o então presidente Collor de Mello, já alvo de uma CPI no Congresso, convocou os brasileiros a irem às ruas vestidos das cores da bandeira nacional: "vamos inundar o Brasil de verde e amarelo" (O Globo, 2015), disse ele. A resposta dos intérpretes foi a oposta da intencionada, pois a população vestiu-se e decorou

\footnotetext{
${ }^{30}$ Dicionário Português Oxford University Press (C 2012 Editora Objetiva. Versão eletrônica para Macintosh.
} 
janelas e fachadas de preto, impulsionando a instauração do processo de impeachment. Collor renunciou em dezembro do mesmo ano.

\section{Discurso (9) da Cor-Código: Coca-Cola, em discurso designativo-incitivo.}

(a)

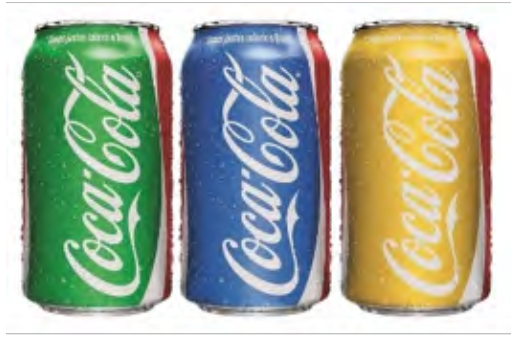

(b)

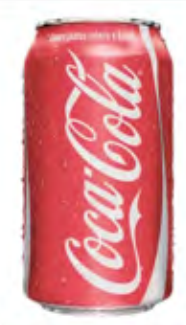

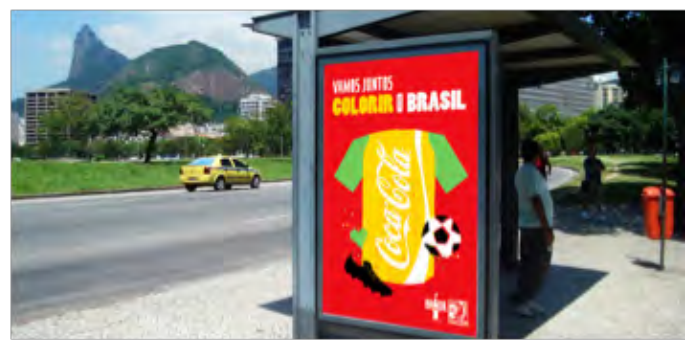

(c)
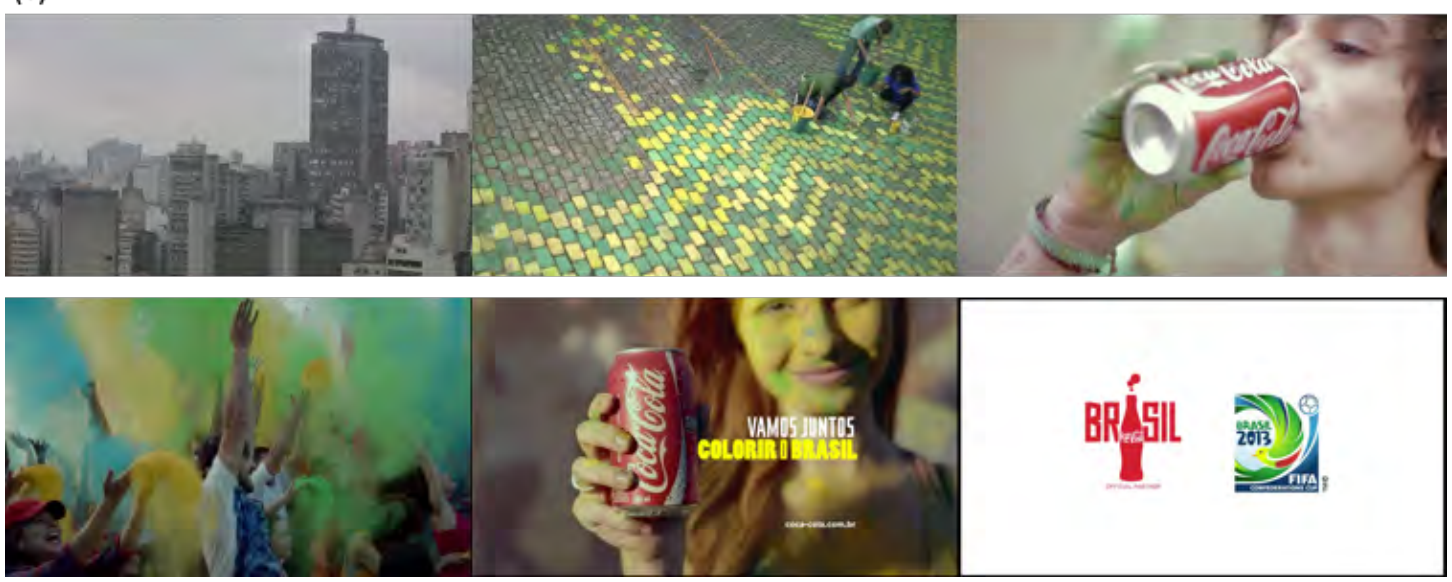

Marca: Coca-Cola, na promoção "Vamos juntos colorir o Brasil", para a Copa das Confederações da FIFA, em 2013.

Cores: vermelha (designadora de Coca-Cola), verde, azul e amarela (de Brasil).

\section{Pontos-de-contato analisados}

(a) Embalagens promocionais, frentes e verso; (b) Mídia exterior e ambientação de estação de metrô, entre outros materiais gráficos; (c) Filme da campanha.

\section{Modo proeminente de significação das cores: DESIGNATIVO}

- As cores são as designativas da Coca-Cola e da bandeira do Brasil. O uso do vermelho minimiza o efeito transformativo das cores brasileiras em um dos lados da latinha.

\section{Uso principal do signo-cor: INCITIVO}

Além do slogan convidar literalmente a uma ação "Vamos juntos colorir o Brasil", o filme pareia o ato de beber Coca-Cola (não fala nem mostra o comprar ou colecionar) com a ação de colorir o Brasil (unhas, cara, ruas, etc.). Os cenários vazios e acinzentados da cidade são pintados, se enchem de pessoas e das cores do país e da Coca-Cola.

Fontes: (a, b) Site da Tátil Design de ideias (2013); (c) Site da agência Wieden+Kennedy (2013). 
Para Morris, o discurso designativo-incitivo configura o tipo "legal” (1946, pp. 130132), a "linguagem das leis" que objetiva incitar os indivíduos a agirem de uma ou outra forma, ao designar recompensas ou punições compromissadas pelo grupo ou sociedade, caso as ações sejam ou não realizadas pelos seus membros. Esse tipo discursivo não aprecia, nem prescreve a execução das gratificações ou castigos designados: caso o grupo interessado não as execute, o emissor do discurso pode perder sua capacidade sígnica persuasiva ao longo do tempo.

\section{A Cor-da-Moda (discurso cromático apreciativo-incitivo)}

A "cor-da-moda" é o discurso para engajar os públicos com a marca por meio da apreciação da cor de uma temporada, geralmente já discursada (positivamente avaliada) como a cor-do-ano. Porém, enquanto a cor-do-ano se dedica a estabelecer a preferência pela marca que proclama a cor, a cor-da-moda tem o objetivo direto de provocar comportamentos (de compra, de uso, exibição, recomendação, etc.) para a marca emissora do discurso.

O discurso da cor-da-moda, assim como a cor-do-ano, é majoritariamente realizado pela indústria de vestuário, beleza, de design, etc. Apesar de distintos em seus objetivos primeiros, o discurso da cor-do-ano e o da cor-da-moda são altamente entrelaçados, e frequentemente ocorrem juntos, com proeminência similar em uma mesma peça de comunicação ou ativação. Por exemplo, em desfiles de moda, uma marca proclama suas cores-do-ano (a fim de gerar avaliações positivas de autoridade, glamour, admiração) e simultaneamente usa essas cores em discurso da cor-da-moda (o desfile visa também incitar ações de compra, recomendações em editoriais de moda, etc.). Outro exemplo de entrelaçamento se dá com as marcas que não possuem autoridade (nem orçamento) suficiente para eleger uma cor-do-ano. Elas podem se apropriar das cores positivamente avaliadas por outras marcas, aplicando-as em suas ofertas discursando, assim, a cor-da-moda.

Além disso, o discurso da cor-da-moda é realizado nas lojas físicas e online, nas redes sociais, e em merchandising editorial. Os veículos de mídia especializados (moda, decoração, etc.), oferecem duplas oportunidades das marcas discursarem a cor-da-moda: para marcas anunciantes, a fim de vender seus produtos e serviços, e para as marcas dos próprios veículos, as revistas, portais e blogs de formadores(as) de opinião, a fim de obter tráfego (leitura, clicks, comentários e compartilhamentos) e, consequentemente, vender mais e a maior preço os seus espaços publicitários e publieditoriais (informe-publicitário). 
Discurso (10) da Cor-da-Moda: Glamurama e Impala, em discurso apreciativo-incitivo.

(a)

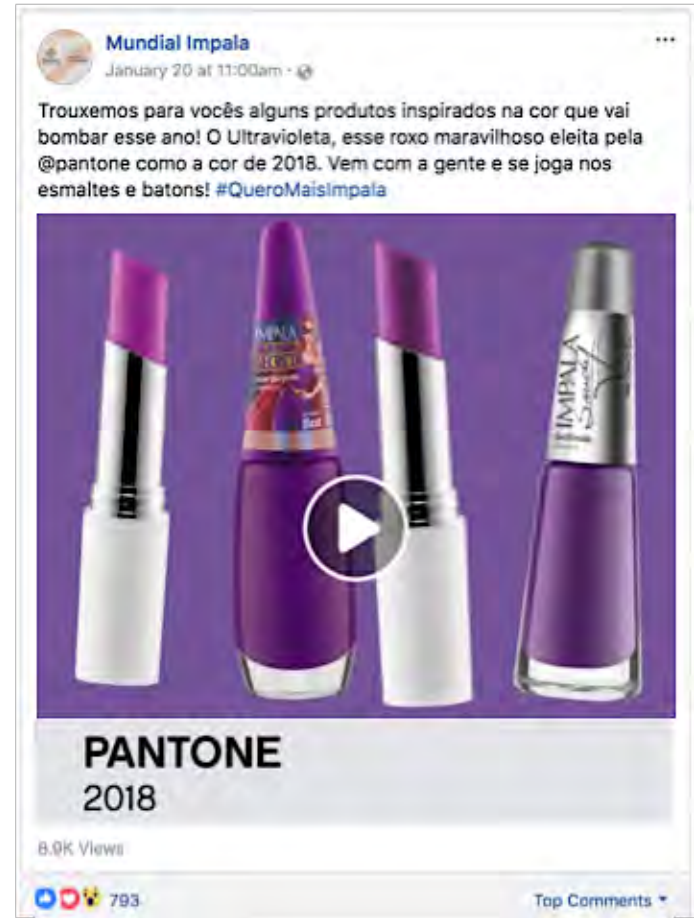

(b)

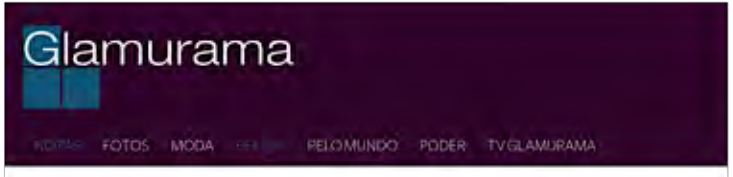

Ultra Violet: como usar a cor eleita pela Pantone para 2018 na maquiagem?

Que tal apostar no roxo intenso nas unhas? A aposta pode ser o cremoso Obsessão ou o metálico Psico. Ambos são da tonalidade indicada pela Pantone, mas com diferentes acabamentos. Assim, dá para aderir à tendência sem deixar de variar o esmalte.

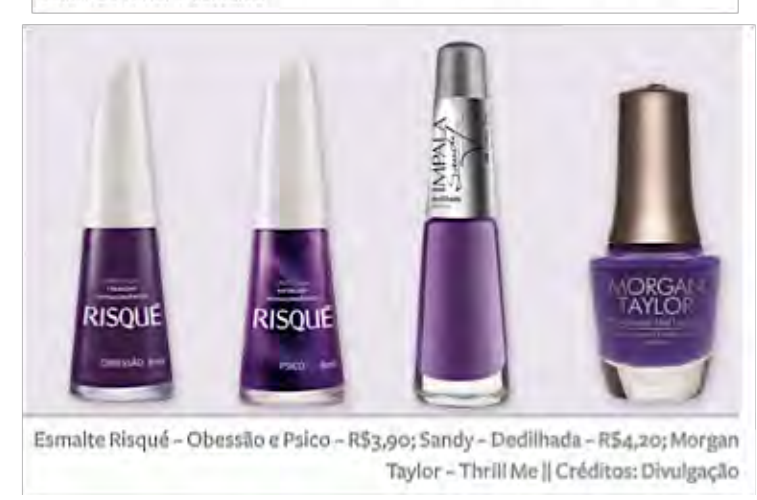

Marcas: (a) Impala, Pantone, (b) Glamurama (indiretamente Risqué, Impala, Morgan Taylor). Cor: ultra-violet, eleita a cor-do-ano de 2018 pela Pantone.

\section{Pontos-de-contato analisados}

(a) Postagem no Facebook Impala (esmaltes); (b) Publieditorial da revista online Glamurama.

\section{Modo proeminente de significação da cor: APRECIATIVO}

- Cores apreciadas graças a discursos anteriores (da cor-do-ano, pela Pantone, uma marca-autoridade): (a) "O ultraviolet, esse roxo maravilhoso eleito pela @pantone como a cor de 2018...”, (b) “... ambos são a tonalidade indicada pela Pantone, mas com diferentes acabamentos".

\section{Uso principal do signo-cor: INCITIVO}

- As marcas incitam ações pelas cores apreciadas: (a) "vem com a gente e se joga nos esmaltes e batons", (b) Que tal apostar no roxo intenso nas unhas?".

Fontes: (a) Conta oficial da marca no Facebook < www.facebook.com/mundial.impala/ > (b) Revista online Glamurama (2017). Acesso em 10/01/2018.

O grande risco que as marcas enfrentam com o discurso cromático da moda é a homogeneização de suas ofertas, que vai contra um princípio central do valor marcário: distintividade em relação aos concorrentes. Assim, quando a cor-do-ano se torna a cor-da-moda generalizada na categoria, as marcas de maior valor e autoridade devem criar e lançar as (novas) 
cores da (próxima) estação. Nesse caso, fica clara a interdependência dos discursos da cor-damoda, cor-do-ano e cor-disruptiva.

Existe a tendência óbvia para uma cor, mas é muito importante que a individualidade de cada designer seja reconhecida nessa cor. Raramente você verá diferentes designers, na mesma época, usando a mesma cor da mesma maneira. Na perspectiva do luxo, da altaqualidade, existe um individualismo no design, que faz com que algo pertença a uma marca.... Então eu não acho que a marca de luxo tem que necessariamente usar a cor da moda. $\ldots$

Para a moda prêt-à-porter e de passarela, é uma coisa. Outra coisa é com os acessórios, é necessário seguir a cor da tendência, porque isso atrai mais pessoas para comprar a cada estação, para mudar seu visual. É mais fácil comprar um par de sapatos ou uma bolsa nova do que comprar um look completo. (Depoimento de especialista - Louboutin)

No trabalho de Morris, a convergência do modo apreciativo com o uso incitivo é tipificada como discurso "moral" (1946, pp. 138-140), diretamente relacionado com o controle do comportamento social. Apreciando (ou denegrindo) ideias e ações, o discurso moral as qualifica como favoráveis (ou desfavoráveis), sob ponto de vista de um certo grupo. Por estimular ou coibir, esse tipo discursivo é usado para controlar a conduta geral de um grupo de pessoas. Assim, as ações e ideias que interessam ao produtor do discurso (pessoa, marca de empresa, instituição, governo, etc.) serão avaliadas como morais, éticas e dignas, e aquelas que não interessam, como imorais, vergonhosas, infames.

Se escolhermos uma cor e começarmos a anunciá-la, aplicando-a em nossos veículos, em propagandas nas revistas, na TV, nos outdoors... isso irá influenciar, ou como eu chamo, inspirar alguém a comprar essa cor. Talvez haja uma magia ... talvez haja uma pessoa que sempre compre prata ou preto, mas de repente ela verá um azul brilhante e vai achar bonito. As pessoas podem ser persuadidas a comprar essa cor. É possível, já vimos isso acontecer. (Depoimento de especialista - Ford Motor Company)

\section{A Cor-Mania}

(discurso cromático prescritivo-incitivo)

O discurso da "cor-mania", é aquele que pretende engajar os consumidores por meio da prescrição de cores. Os consumidores, arrebatados pela persuasão discursiva, agem em direção à marca (compram, usam, exibem, comentam, postam), comandados pelas cores. 
Muitas pessoas compram nossa camiseta, nossos produtos... eles não se importam se não é bom - e acreditamos que nossos produtos sejam muito bons - mas eles compram apenas por causa da cor roxa. (Depoimento de especialista - Purple)

Por ser o cruzamento do modo prescritivo com o uso incitivo, a marca não objetiva primariamente que o consumidor goste da cor (a marca faz isso por outros discursos), não enaltece as cores, nem as carrega de sentido positivo. Quando a ação de um indivíduo é diretamente provocada por uma cor que parece ter "falado" ou "puxado" o intérprete, a marca proferiu o discurso da cor-mania - e ele foi bem-sucedido. Geralmente, mas não obrigatoriamente, esse discurso provoca um maior efeito se as cores já foram positivamente avaliadas e prescritas por outros discursos, como o da cor-do-ano e o da cor-da-moda.

As campanhas que exploram o conhecido "princípio da escassez" (Cialdini, 2001, pp. 203-232), frequentemente utilizam o discurso da cor-mania. Ao lançar uma edição limitada, promoções com brindes, embalagens ou produtos colecionáveis que incluam variações de cores, a marca incita o consumidor pela pressão da escassez (da cor), a comprar, recomprar, juntar, exibir-se, postar, comentar, etc. A marca produtora do discurso não precisa enaltecer as cores: elas e a marca serão valorizadas na medida em que são percebidas como menos disponíveis.

Somos considerados um parceiro estratégico para a Lululemon, e geralmente usamos seus produtos centrais, que não são sazonais... você pode comprá-los durante todo o ano. Eles são principalmente em preto, branco e cinza....

Quando eu estava selecionando os produtos, incluímos variações de azul. Para as mulheres, havia uma cor no verão passado, a Bali Breeze, um azul turquesa atraente e vibrante.... Esse azul puxava as pessoas para a loja quando elas o viam pendurado na prateleira da frente da Roam! Elas queriam entrar e comprar porque viam a cor. Ela é uma cor sazonal... nós não a teremos mais. ...

Nas lojas [Lululemon] eles mudam essas paredes semanalmente... eles têm muito conhecimento e dados sobre como usar a cor para influenciar a experiência dos clientes. (Depoimento de especialista Roam Fitness)

Apesar de ser conhecida pela extrema adequação do uso das cores, um exemplo recente de discurso da cor-mania malsucedido vem também da Lululemon Athletica, marca de moda esportiva premium. Ao final do primeiro trimestre de 2017, o fraco desempenho nas vendas e a queda no valor das suas ações na bolsa de Nova York, foram diagnosticados como 
consequência da falta de cor na coleção de primavera (hemisfério norte), problemas que a marca enfrentou com a adição urgente de novas cores ao sortimento (Assis, 2017).

\section{Discurso (11) da Cor-Mania: Chandon, em discurso prescritivo-incitivo.}

(a)

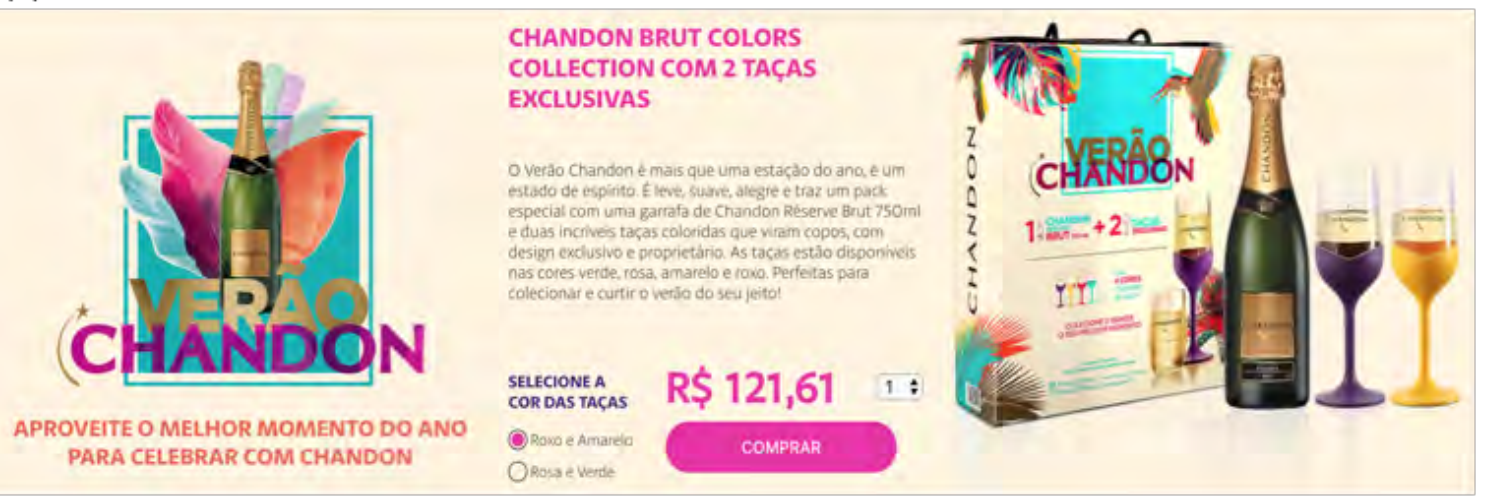

(b)
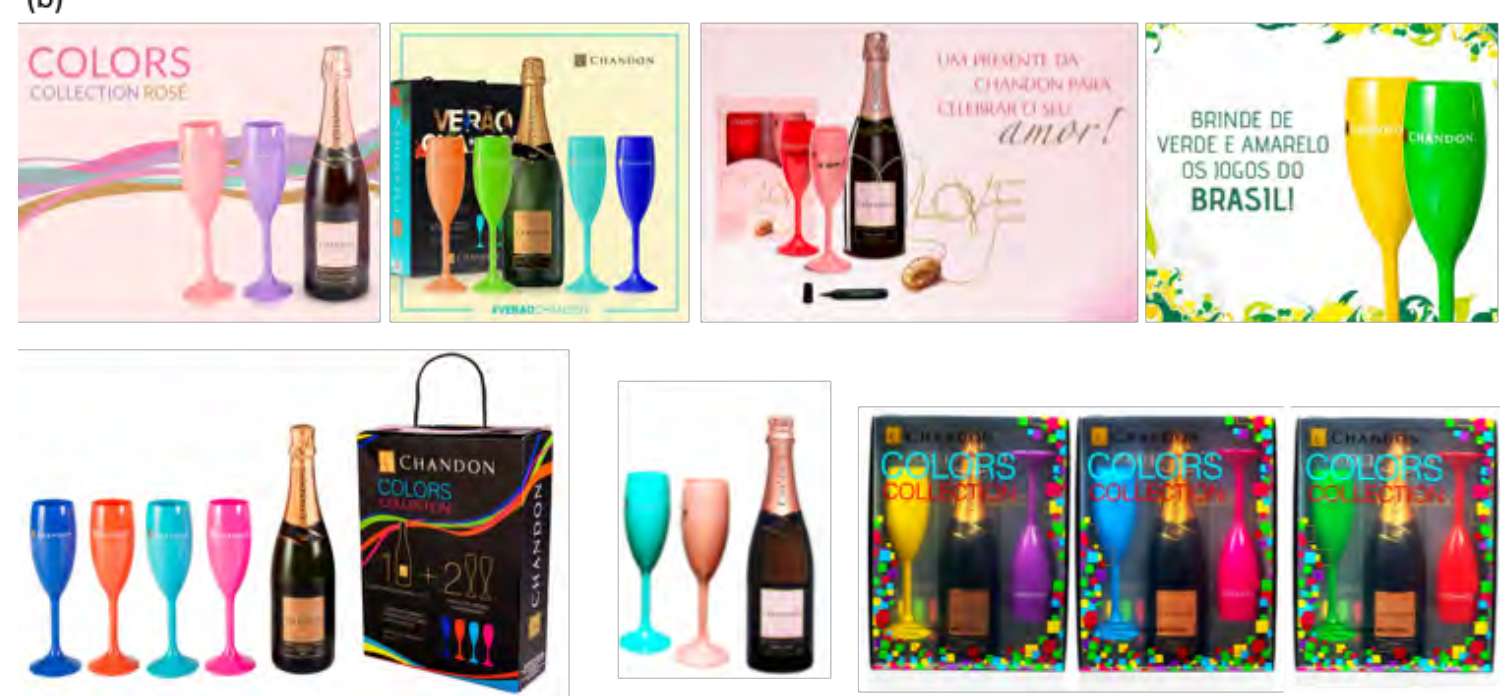

Marca: Chandon, com “Colors Collection” (2012-2017), e "Verão Chandon” (2017-2018). Cores: edições de 2 a 6 cores de taças colecionáveis, dependendo do ano e da ocasião (réveillon, copa-do-mundo, dia dos namorados).

\section{Pontos-de-contato analisados}

(a) Loja Chandon do Brasil, online; (b) posts no perfil oficial do Facebook, de 2012 a 2015.

\section{Modo proeminente de significação das cores: PRESCRITIVO}

- A cor é prescritora de ações, reforçadas nos textos: (a) Aproveite o melhor momento", "Colecione". As cores não seguem a cor-da-moda, e nas vezes que designavam a ocasião, como nos dia-dos-namorados (vermelho/rosa = amor) e nos jogos da Copa do Mundo (verde/amarelo= brasilidade), os valores positivos não foram explorados na comunicação. - As campanhas, com o apoio da cor, prescrevem comandos, como (b) "Celebre o amor" ou

"Brinde de verde e amarelo os jogos do Brasil!". 


\section{Uso principal do signo-cor: INCITIVO}

- O objetivo é incitar a compra e recompra. Em entrevista, a gerente de marketing da Chandon dp Brasil declarou: “...a ideia é que a pessoa colecione e que tenha quantas taças amarelas, ou roxas, rosas, ou vermelhas, ou verdes, ou azuis ela quiser!” (TV UOL, 2012).

Fontes: (a) Revendedor online oficial (Chandon, 2017); (b) Perfil oficial do Facebook /chandonbrasil/. Último acesso em 20/01/2018.

Morris chamou o encontro do modo prescritivo com o uso incitivo, de discurso "religioso" (1946, pp. 146-148), o qual pretende incitar o intérprete a agir, não primariamente descrevendo ou apreciando comportamentos, mas diretamente prescrevendo-os. O discurso religioso de muitas igrejas (a Cristã, por exemplo) é fortemente ligado ao discurso do tipo moral: enquanto o moral (análogo ao discurso cor-da-moda) aprecia, o discurso religioso (cormania) decreta comportamentos, que são executados ao provocarem nos intérpretes a crença que suas vidas estarão mais satisfatoriamente focadas e direcionadas.

\section{A Cor-Criação \\ (discurso cromático transformativo-incitivo)}

O discurso transformativo-incitivo é aqui denominado como "cor-criação", no qual as marcas incitam seus públicos a se engajarem com as inúmeras possibilidades cromáticas oferecidas em ações de customização de massa ou customização personalizada (viáveis no caso de marcas de alto luxo).

Cada versão - diferente, única, inédita - co-criada com o consumidor, é uma nova manifestação cromática da marca. Por vezes, as opções de cores são limitadas, preestabelecidas pelas marcas. Por outras, mais raras, o consumidor pode obter exatamente a cor que deseja, manipulando os elementos sintáticos da cor (matiz, brilho e saturação). A marca define as regras combinatórias (a depender da logística, da tecnologia, etc.), o intérprete cria a melhor versão cromática para si. 
Discurso (12) da Cor-Criação: Skype, em discurso transformativo-incitivo.
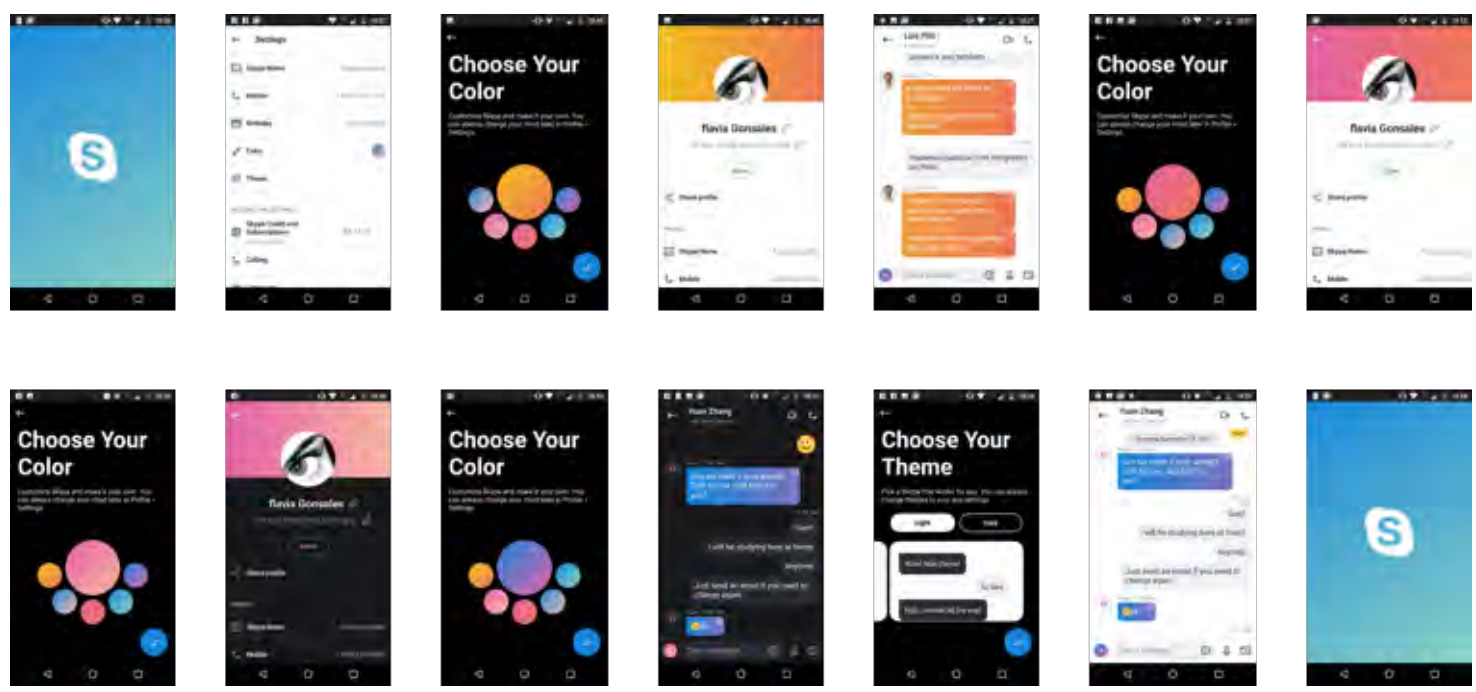

Marca: Skype.

Cores: 6 opções de cores predeterminadas $\times 2$ opções de tema (fundo branco ou preto).

\section{Ponto-de-contato analisado:}

Telas do aplicativo para celular, sistema operacional Android.

\section{Modo proeminente de significação das cores: TRANSFORMATIVO}

O usuário tem 12 opções de dégradé de cor e de fundo, que alteram a faixa de fundo do perfil, os ícones do app, e balão de diálogo da pessoa com quem o usuário fala. O dégradé identificativo do Skype, que vai do azul identificativo ao verde-azulado, não é alterado.

\section{Uso principal do signo-cor: INCITIVO}

O Skype incita o usuário a cocriar com ele, personalizando as cores da interface do aplicativo:

"Customize o Skype e faça-o seu. Você sempre poderá mudar de ideia mais tarde...";

"Escolha um tema: Selecione um tema que funciona para você...".

Fonte: Captado do celular da pesquisadora em 17/01/2018.

Marcas de várias categorias discursam pela cor-criação. Desde softwares e aplicativos móveis (Twitter, Skype, Messenger, do Facebook), vestuário esportivo (Nike iD, MiAdidas), até marcas de bens duráveis. Por exemplo, a linha Brastemp You, existente até os primeiros anos da década de 2000, era uma "linha personalizável" de cores de geladeiras, lava-louças e fogões. As marcas de automóveis também exploram o discurso, disponibilizando a escolha e combinação de cores externas (cor do carro e dos acabamentos) e internas (estofamento e acessórios).

Nada mais inovador do que você customizar um refrigerador. E não foi só a cor [geral]: foi a cor da parte de cima, da porta de baixo, do puxador. Começou só com geladeira e cooktop, depois outras coisas, 
mas a grande sacada foi a geladeira, que é o grande representante da cozinha, o carro chefe. Se você quer colocar... cor... estilo, você faz na geladeira e já deu, o resto é simples... Fizemos uma pesquisa grande de cores e tendências, ... chegamos a 15 cores e depois limpamos até nove ou 10 cores.

Esse produto foi feito para atender o consumidor, mas era para sustentar certas estratégias de marketing... muito mais do que vender volume, não vendia volume, mas trazia uma mídia espontânea que era uma coisa impressionante, não havia marca no mundo de eletrodoméstico que oferecia isso aos consumidores. $\cdots$

Havia um número muito grande de pessoas que entravam no site, navegavam, mas não realizavam a compra. No último ano da linha You [...] as pessoas entravam na plataforma, montavam dois ou três modelos diferentes e eles podiam compartilhar os modelos nas redes sociais, para que os amigos votassem qual dos três era o mais bonito, então você podia comprar o mais votado.

$\ldots$

A cor está muito presente na vida do brasileiro e na vida dos consumidores que querem coisas novas. Todo muito está cansado dos mesmos produtos das mesmas cores, e naquele momento a cor era a expressão máxima disso. (Depoimento de especialista Whirlpool)

Na tipologia de Morris, a junção do modo formativo de significação com o uso incitivo foi denominado de "gramatical". Como exemplos desse tipo discursivo que não designa, não aprecia, nem prescreve, mas pretende incitar o intérprete à ação, tem-se: "Ou você vem, ou não vem!", para apressar alguém; uma tabela de declinação de adjetivos na língua russa, que recitada ajuda a si ou um outro a aprender russo; o esquema de estrofes, rimas e métrica de um soneto, cuja prática faz o hábito de escrever poemas (Morris, 1946, pp. 173-175).

A descrição de discurso gramatical Morrisiano não se encaixa diretamente no discurso da cor-criação, mas inspirou sua delimitação: do mesmo modo que a gramática tem suas regras sintáticas para a combinação dos elementos compositivos, a cocriação pela cor permite o consumidor manipular os elementos e cores disponibilizadas para customização. 


\subsection{O discurso cromático para organizar as marcas}

Discursos cuja principal função é organizar as diferentes respostas que um signo, ou uma combinação sígnica (ascriptor) provoca, são discursos sistêmicos. Em sua tipologia, Morris diferenciou quatro tipos sistêmicos, a depender do modo de significação em que o signo opera. Porém, na tipologia aqui proposta (Quadro 4.6), a diferenciação dos diferentes discursos cromáticos sistêmicos em função do modo descritivo, apreciativo, persuasivo ou transformativo da cor operar, não se mostrou profícua, nem possível.

Quadro 4.6: O discurso cromático sistêmico, abarcando os quatro modos de significação.

\begin{tabular}{|c|c|}
\hline MODO USO & USO SISTÊMICO DO SIGNO-COR \\
\hline DESIGNATIVO & \\
\hline APRECIATIVO & Cor-Estrutura (discurso marcário multimodal sistêmico) \\
\hline PRESCRITIVO & \\
\hline TRANSFORMATIVO & \\
\hline
\end{tabular}

Fonte: Desenvolvido pelo autor.

O sistema visual das cores não é estruturado como uma linguagem ${ }^{31}$ no sentido da linguística formalista e é, assim, intrinsicamente diferente do sistema da linguagem verbal, para o qual a tipologia Morrisiana foi primariamente pensada. Conforme discutido ao longo de toda a tese, a inter-relação dos modos de significação, dos usos do signo-cor e, por consequência, dos discursos cromáticos, é extrema: a cor sempre opera no modo designativo para as marcas que a utilizam, e frequentemente opera em outros modos, simultaneamente.

Essa impossibilidade de diferenciação não quer dizer que a cor não funcione como sistematizadora de respostas sígnicas. Ao contrário, as cores são usadas pelas marcas para organizar suas ofertas aos públicos, operando nos múltiplos modos de significação, o que nesta tese é proposto como discurso da "cor-estrutura". Porém, antes de apresentá-lo, os quatro discursos sistêmicos de Morris serão resumidos, a fim de expor o pensamento original do autor.

\footnotetext{
${ }^{31}$ A existência, ou não, de uma gramática da imagem ou de uma linguagem da cor, divide linguistas, semioticistas e pesquisadores de diferentes campos de estudo. Por exemplo, a semiótica social da cor, apoiada na linguística sistêmico-funcional de Halliday, defende a existência de uma gramática do design visual (GDV), referindo-se aos recursos visuais operando como "fonte de (fazer) significados (van Leeuwen, 2005, p. 3). Essa noção opõe-se à perspectiva da linguística formalista, que defende o conceito de gramática como um conjunto de regras que possam ordenar e determinar práticas corretas de combinações.
} 


\section{O discurso cosmológico Morrisiano (designativo-sistêmico)}

Sobre o primeiro discurso sistêmico, Morris afirma ter sido difícil encontrar um que claramente ilustrasse as características do que ele denominou como discurso "cosmológico" (1946, pp. 132-134). Esse tipo discursivo é explicado como "as visões de mundo dos filósofos", que parecem informar sobre o que é realmente esse mundo, e por isso frequentemente confundido com o discurso científico (designativo-informativo). Os exemplos que Morris fornece são: "o universo é um ou vários", o mundo é "composto de substância ou de eventos, é intencional ou mecanicista, hostil ou amigável aos valores humanos” (1946, p. 133).

\section{O discurso crítico Morrisiano (apreciativo-sistêmico)}

O discurso "crítico" é o mais nitidamente definido por Morris, entre os sistêmicos (1946, pp. 140-142). Na linguagem verbal, a crítica de um texto, de um trabalho, de um filme, etc. é uma apreciação positiva ou negativa que permite o intérprete reorganizar, reestruturar suas impressões em relação ao objeto analisado. Esta tese mostrou que marcas podem criticar seus concorrentes, e eventualmente se autocriticarem, por meio das cores em conjunção com slogans e textos publicitários. Esse tipo de uso sígnico, porém, foi classificado e comentado nos usos e discursos cromáticos avaliativos.

\section{O discurso propagandístico Morrisiano (prescritivo-sistêmico)}

Por sua vez, a conjunção do modo prescritivo com o uso sistêmico define o discurso "propagandístico" (1946, pp. 148-150). Morris diz ser um discurso difícil de ser isolado, uma vez que é usado para inúmeras funções secundárias e devido à frequente dependência de signos apreciadores: é constantemente entrelaçado com as linguagens discursivas poética (apreciativoavaliativo), moral (apreciativo-incitiva) e crítica (apreciativo-sistêmico). Exemplos desse discurso Morrisiano são as colunas editoriais de jornais e revistas, prescrevendo ações na intenção de reorganizar a opinião pública.

\section{O discurso metafísico Morrisiano (formativo-sistêmico)}

Esse último discurso é denominado como "metafísico", um termo que, segundo Morris, é por si só controverso, condenado por uns, aclamado por outros (1946, pp. 175-178). O discurso é caracterizado como de máxima generalidade e exemplificado por Morris, com as frases: "Nada 
é ou não é"; "A mudança é da natureza do ruim"; "Somente as realidades são reais", e suas alegações opostas “Tudo é e não é”; "Mudança não é ruim”; "Não só as realidades são reais".

Expostos os discursos “verbais" sistêmicos Morrisianos, a tese propõe agora um único tipo discursivo cromático sistematizador, que abarca todos os modos de significação (multimodal).

\section{A Cor-Estrutura}

(discurso cromático multimodal sistêmico)

O discurso da cor-estrutura é o discurso que organiza ou reorganiza as percepções dos públicos sobre uma marca ou sobre um conjunto de marcas de uma mesma corporação (uma marca corporativa). O uso sistêmico do signo cor (seção 3.4) influencia os demais usos da cor (informativo, avaliativo e/ou incitivo), com a cor operando indiferentemente nos modos designativo, apreciativo, incitivo e transformativo.

Nos casos analisados, a cor organizou as marcas por dois modos básicos: por similaridade e diferenciação. Quando a organização visa provocar uma resposta de unificação, de agrupamento, é utilizada um única cor ou cores similares. Este é o caso da organização do portfólio da Tiffany, da Louboutin, das brasileiras Nubank, Bauducco e Sadia.

Para obter o efeito organizador contrário, de separação, as cores usadas são as mais diferentes possíveis. Isso é válido para diferenciar a marca de suas concorrentes, marcas independentes que pertençam a uma mesma empresa, ou ofertas diferentes sob uma única marca. Como exemplos, tem-se o portfólio da Procter \& Gamble (e as inúmeras cores aplicadas do sabão em pó Ariel às fraldas Pampers), o portfólio de luxo da LVMH (quem poderia dizer que Möet Chandon, Veuve Clicquot, Dom Pérignon, Louis Vuitton, Dior, Kenzo, entre muitas outras, pertencem ao mesmo grupo?), e as pastilhas de chocolate M\&Ms (cores diferentes para causar a percepção de variedade).

A combinação dos efeitos de agrupar e de separar é típica em extensões de (mono)marca e em portfólios de submarcas. Por exemplo, a cor vermelha unifica as ofertas da Coca-Cola abaixo do seu guarda-chuva, enquanto as cores prata, preta e verde, diferenciam as versões de adoçante. O laranja unifica os serviços do Itaú, enquanto as variações na quantidade e na saturação desse laranja (e do azul) hierarquizam os serviços oferecidos. O branco da Dove 
unifica as ofertas para mulheres e para bebês, enquanto o cinza escuro da Dove Men+Care, distancia a submarca masculina da marca-mãe, feminina.

A American Airlines tem que ser azul e vermelha ... eles têm todo um sistema em torno dessas cores. Nós mudamos o azul para um celestial, colocamos o branco das nuvens e tem a águia [em vermelho].... Temos todo um sistema que nem todo mundo vê: da classe econômica à primeira, na embalagem das coisas que você compra no avião, um lanche ou queijo, com uma paleta de cores secundárias fortes, com laranja, verde. As grandes marcas usam cores realmente como um sistema.

$\ldots$

Se a marca tem múltiplas segmentações e perfis de clientes, geralmente usa a cor como um elemento disso.... Com a American Airlines, assim como na UPS, você tem pessoas em diferentes segmentos, vendo várias cores. Um cliente de primeira classe vai ao aeroporto e verá o azul e o vermelho, porque é assim a sinalização é da American Airlines, e no embarque da primeira classe, as cores mudam. A coisa toda é um sistema... Depende de quem é o comprador. $E$ isso é muito intencional. (Depoimento de especialista FutureBrand)

Discurso (13) da Cor-Estrutura: American Airlines, em discurso multimodal sistêmico.

(a)
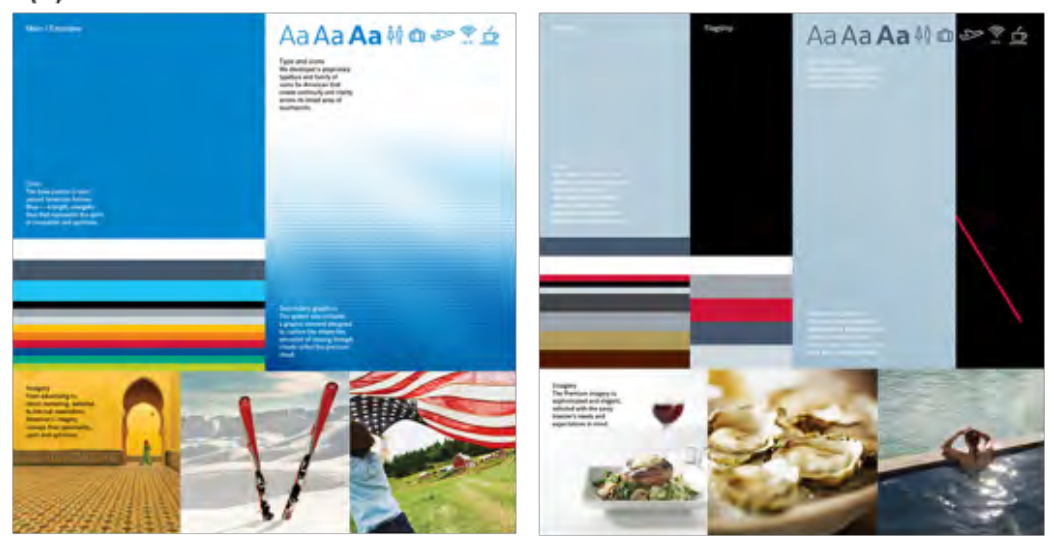
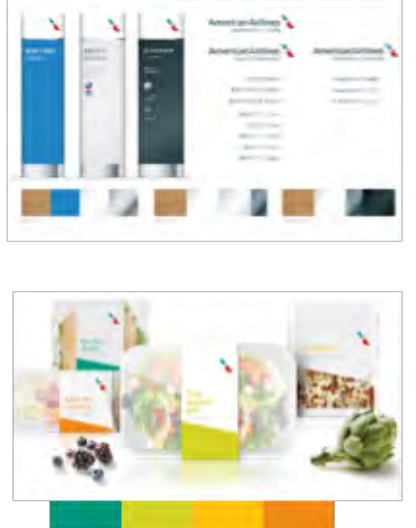

(b)

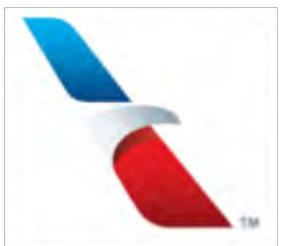

American Airlines
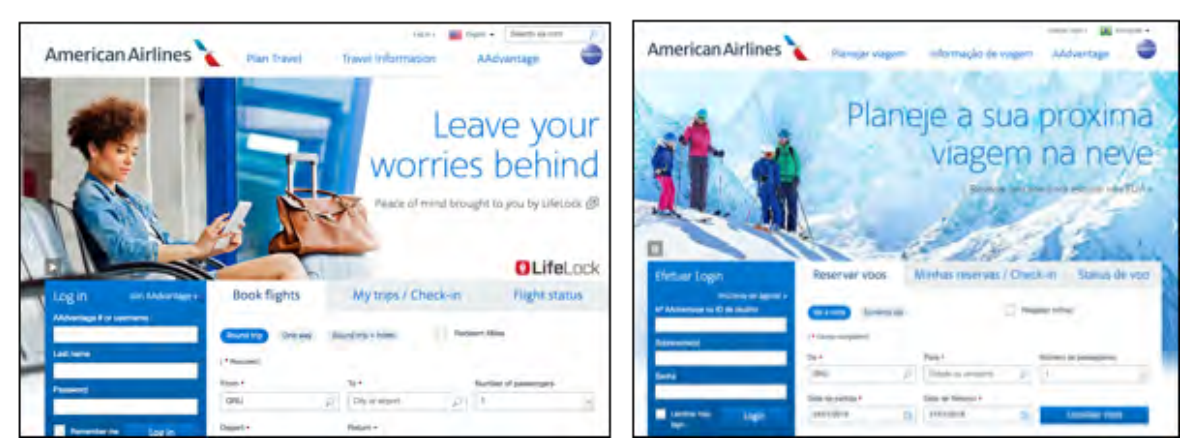
(c)
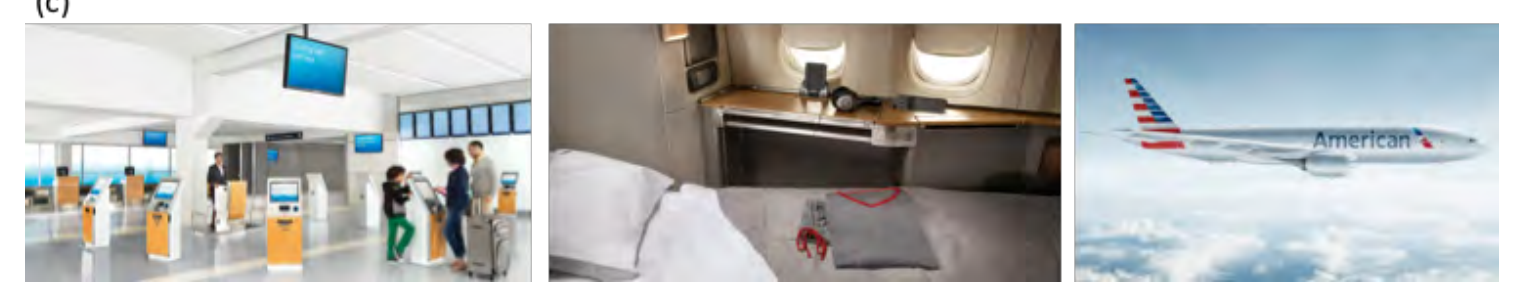

Marca: American Airlines.

Cores: a partir do vermelho, azul e branco designadores da marca, uma paleta de cores organizadoras foi criada.

\section{Pontos-de-contato analisados}

(a) Manual da marca; (b) Logotipos e site da marca; (c) Aeroportos e aeronaves.

\section{Modo proeminente de significação das cores: MULTIMODAL}

- O vermelho, o azul e o branco são as cores designadoras da marca (modo designativo).

- As cores da bandeira americana provocam respostas apreciativas positivas em americanos (e eventualmente em consumidores de outras nacionalidades); os tons mais desaturados e escuros provocam efeitos de superioridade, status social, diferenciando as categorias superiores da categoria econômica (modo apreciativo).

- A diferença entre as cores é pareada com os preços mais altos da classe executiva (Priority) e da primeira classe (Flagship), e os consumidores pagam mais (entre outros comportamentos diferenciados) pelos serviços premium (modo prescritivo).

- As cores mudam ao longo da jornada do consumidor, tanto para os consumidores das classes superiores como os da classe econômica - por exemplo, com as embalagens de comida coloridas (modo transformativo).

\section{Uso principal do signo-cor: SISTÊMICO}

- As cores são utilizadas para organizar o portfólio, influenciando a identificação da marca, a preferência da marca e das diferentes categorias de serviço, e o engajamento dos públicos conforme a classe (categoria) que compram.

Fontes: (a) Portfólio digital do designer Daniele Politini (2012); (b) Sites oficiais americano e brasileiro (American Airlines, 2018a, 2018b); (c) Site da FutureBrand (2012) e visitas de observação.

Enquanto organiza, o discurso da cor-estrutura requer e influencia todos os modos e usos das cores, por uma marca. Esse discurso é uma síntese exemplar dos tipos discursivos cromáticos: explicita a interdependência das diversas respostas possíveis dos intérpretes frente ao signo-cor, e inter-relaciona as diferentes funções para as quais as marcas utilizam as cores. 


\section{Considerações finais}

Todas as marcas, intencionalmente ou não, discursam visualmente por meio da cor. Por diferentes maneiras, em variadas intensidades, a cor é sempre uma faceta da materialização marcária. Não existe marca sem cor.

Conforme discutido, os modos da cor significar uma marca, aos seus públicos, são múltiplos, ambivalentes e inter-relacionados, e vão muito além dos pouco-criativos estereótipos explorados à exaustão. As intenções da marca ao utilizar as cores também são variadas, não restritas à tão difundida função identificadora, que requer a cor imutável. $\mathrm{O}$ uso da cor, pelas marcas, se mostra adequado quando "coerente", mais do que "consistente".

Ao evidenciar o signo-cor como polissêmico na significação e multifuncional nos usos, a tese delineou 13 tipos de discursos cromáticos distintos, interdependentes e não excludentes. Essas 13 estratégias discursivas podem servir como modelos auxiliares no planejamento e nas tomadas de decisão, em processos de criação, promoção, extensão e/ou reposicionamento de marcas, por profissionais da comunicação, do design, e da gestão. Além disso, as teorias dos modos e dos usos da cor, assim como a tipologia dos discursos cromáticos, são ferramentas úteis para a análise de materiais de comunicação e expressão de marca, seja na prática mercadológica, na formulação de políticas públicas (consumo consciente, defesa do consumidor, etc.), ou no âmbito acadêmico (para fins de pesquisa ou de ensino).

Respondendo à inquietação inicial deste trabalho, cada tipo discursivo se revela como uma possibilidade de protagonismo cromático na manifestação de marca. A cor pode ser o personagem onipresente-onipotente (cor-assinatura), a heroína mágica e poderosa (cor-mito), o excêntrico louco (cor-disruptiva), a personalidade cativante e otimista (arco-íris), o poeta apaixonado por seus ideais (cor-alegoria), a grande eleita (cor-do-ano), a celebridade mais popular (cor-da-moda), o galã ou a estrela que todos querem possuir e ser possuídos (cor-mania), etc...

Porém, o papel de protagonista só será confirmado na medida em que a cor fizer sentido junto ao público (sentido de si, dos outros, do contexto). Se o protagonista às vezes vira o antagonista da história, ou torna-se um coadjuvante da novela, na dialética da marca-cor- 
consumidor, a cor mocinha pode virar a cor bandida, ou um elemento secundário. Mesmo assim, continua a exercer funções comunicativas e a significar a marca para os indivíduosconsumidores da sociedade do espetáculo (das imagens), da informação, conectada em rede.

Esta tese, ao adaptar e ampliar a tipologia semiótica dos discursos de Morris para as cores e marcas, faz um convite ao estudo dos modos e usos sígnicos dos demais elementos marcários visuais (tipografia, mascote, embalagem, propaganda, etc.). Ainda que a obra Morrisiana se proponha aplicável para qualquer tipo de signo, a investigação das potenciais interpretações e peculiaridades funcionais de cada elemento pode ajudar em um entendimento mais aprofundado dos fenômenos da marca e do consumo visual, na contemporaneidade.

...as dificuldades documentais, metodológicas e epistemológicas destacam a relatividade cultural de todas as questões que afetam a cor. Elas não podem ser estudadas fora do contexto cultural, fora do tempo e do espaço. Do mesmo modo, qualquer história das cores deve primeiro ser uma história social. Para o historiador - assim como para o sociólogo e para o antropólogo - a cor é definida antes de tudo como um fenômeno social. É a sociedade que "faz" a cor, que Ihe dá suas definições e seu sentido, que constrói seus códigos e seus valores, que organiza suas práticas e determina suas participações. Não é o artista ou o cientista; não é apenas o aparelho biológico ou o espetáculo da natureza. Os problemas de cor são, em primeiro lugar, problemas sociais, porque o homem não vive sozinho, mas em sociedade ${ }^{32}$

Michel Pastoureau

\footnotetext{
32 "Ces difficultés documentaires, méthodologiques et épistémologiques mettent en valeur le relativisme culturel de toutes les questions qui touchent à la couleur. Elles ne peuvent pas s'étudier hors contexte culturel, hors du temps et de l'espace. Par là même, toute histoire des couleurs doit d'abord être une histoire sociale. Pour l'historien - comme du reste pour le sociologue et pour l'anthropologue - la couleur se définit d'abord comme un fait de société. C'est la société qui « fait » la couleur, qui lui donne ses définitions et son sens, qui construit ses codes et ses valeurs, qui organise ses pratiques et détermine ses enjeux. Ce n'est pas l'artiste ou le savant ; ce n'est pas non plus seulement l'appareil biologique ou le spectacle de la nature. Les problèmes de la couleur sont d'abord et toujours des problèmes sociaux, parce que l'homme ne vit pas seul mais en société" (Pastoureau, 2006, p. 57).
} 


\section{Referências bibliográficas}

De acordo com o estilo APA (American Psychological Association).

Aaker, D. A. (1998). Marcas: brand equity, gerenciando o valor da marca. (Elsevier, Ed.). São Paulo.

Aaker, D. A., \& Joachimsthaler, E. (2000). The Brand Relationship Spectrum: the key to the brand architecture challenge. California Management Review, 42(4), 8-23.

Aaker, D. A., \& Joachimsthaler, E. (2007). Como construir marcas líderes. Porto Alegre: Bookman.

Aboubaker Ettis, S. (2017). Examining the relationships between online store atmospheric color, flow experience and consumer behavior. Journal of Retailing and Consumer Services, 37 (março), 43-55.

Adams, F. M., \& Osgood, C. E. (1973). A Cross-Cultural Study of the Affective Meanings of Color. Journal of Cross-Cultural Psychology, 4(2), 135-156.

Adnews. (2017, 14 de setembro). Infográfico mostra o poder das cores no marketing e no dia a dia. Revista Exame Online. São Paulo. Disponível em http://adnews.com.br/publicidade/infografico-mostra-o-poder-das-cores-no-marketing-e-nodia-dia.html

Aguillar, R. S. S. R. (2016). Apontamentos acerca da proteção de cores como marca. Revista Da ABPI, Mai/Jun(142), 40-47.

Albers, J. (1963). Interaction of Color. New Haven and London: Yale University Press.

Alhouti, S., Johnson, C. M., \& Holloway, B. B. (2016). Corporate social responsibility authenticity: Investigating its antecedents and outcomes. Journal of Business Research, 69(3), 1242-1249.

Allen, T., \& Simmons, J. (2004). Visual and verbal identity. In R. Clifton (Ed.), Brands and Branding (The Economist Series) (pp. 113-126). London: Profile Books.

American Airlines. (2018a). Airline tickets and cheap flights at AA.com. Acesso em 1 de fevereiro, 2018, de https://www.aa.com

American Airlines. (2018b). Passagens aéreas e melhores tarifas - aa.com. Acesso em 1 de fevereiro, 2018, de https://www.aa.com.br

Amir, O., Lobel, O., \& Ariely, D. (2005). Making consumption decisions by following personal rules. In S. Ratneshwar \& D. G. Mick (Eds.), Inside consumption: consumer motives, goals, and desires (pp. 86-101). London and New York: Routledge. 
Assis, C. (2017, 31 de março). Lululemon admits to color mishap and Wall Street punishes its stock. MarketWatch - Dow Jones \& Co. New York. Disponível em https://www.marketwatch.com/story/lululemon-admits-to-color-mishap-and-wall-streetpunishes-its-stock-2017-03-30

Associated Press. (2009, 23 de novembro). McDonald's rolling out "green" logo in Europe. Food Inc. on NBCNews.com. Berlin. Disponível em http://www.nbcnews.com/id/34111784/ns/business-us_business/t/mcdonalds-rolling-outgreen-logo-europe/\#.WmjLh5M-eRs

Bailey, K. (1994). Typologies and taxonomies : An introduction to classification techniques (Quantitative applications in the social sciences). (C. Thousand Oaks, Ed.). Sage Publications.

Bansal-Travers, M., O’Connor, R., Fix, B. V., \& Cummings, K. M. (2011). The impact of cigarette pack design, descriptors, and warning labels on risk perception in the U.S. American Journal of Preventive Medicine, 40(6), 674-82.

Barbosa, D. B. (2013). Novos estudos em Propriedade Intelectual 2011-2013 (vol. 1).

Barry, T. E., \& Howard, D. J. (1990). A Review and Critique of the Hierarchy of Effects in Advertising. International Journal of Advertising, 9(2), 121-135.

Batey, M. (2008). Brand meaning. London: Routledge.

Bauman, Z. (2001). Modernidade líquida. Rio de Janeiro: Zahar.

BBC News. (2000). Heinz to launch green ketchup. Acesso em 18 de março, 2017, de http://news.bbc.co.uk/2/hi/uk_news/828847.stm

BBC News. (2003). Heinz targets children with blue ketchup. Acesso em 18 de março, 2017, de http://news.bbc.co.uk/2/hi/business/2927475.stm

Belch, G. E., \& Belch, M. E. (2008). Propaganda e Promoção: uma perspectiva da comunidação Integrada de marketing (7th ed.). São Paulo: McGraw-Hill.

Bellizzi, J. A., Crowley, A. E., \& Hasty, R. W. (1983). The effects of color in store design. Journal of Retailing, 59(1).

Bellizzi, J. A., \& Hite, R. E. (1992). Environmental color, consumer feelings, and purchase likelihood. Psychology and Marketing, 9(5), 347-363.

Bicas, H. E. A. (1997). Morfologia do sistema visual. Medicina, Ribeirão Preto, 30(1), 7-15.

Birkner, C. (2016, agosto). FedEx Is Making All of Its Logos Purple and Orange, Its Most Recognized Color Scheme. Adweek. Disponível em http://www.adweek.com/news/advertising-branding/why-fedex-consolidating-its-colorscheme-173130

Block, L., \& Kramer, T. (2009). The effect of superstitious beliefs on performance expectations. Journal of the Academy of Marketing Science, 37(2), 161-169.

Bonoma, T. V. (1985). Case Research in Marketing: Opportunities, Problems, and a Process. 
Journal of Marketing Research, 22(2), 199-208.

Bottomley, P. A., \& Doyle, J. R. (2006). The interactive effects of colors and products on perceptions of brand logo appropriateness. Marketing Theory, 6(1), 63-83.

Brakus, J., Schmitt, B. H., \& Zarantonello, L. (2009). Brand Experience: What Is It? How Is It Measures? Does It Affect Loyalty? Journal of Marketing, 73 (maio), 52-68.

Breast Cancer Action. (2017). Think Before You Pink. Acesso em 9 de novembro, 2017, de http://thinkbeforeyoupink.org/

Bublitz, W., \& Norrick, N. R. (2011). Introduction: the burgeoning field of pragmatics. In W. Bublitz \& N. R. Norrick (Eds.), Foundations of pragmatics (pp. 1-22). Walter de Gruyter.

Bucci, E. (2012, 12 de janeiro). Quanto custa o alaranjado? O Estado de São Paulo. São Paulo. Disponível em http://opiniao.estadao.com.br/noticias/geral,quanto-custa-o-alaranjado-imp, 821687

Caivano, J. L. (1998). Color and Semiotics : a two-way street. Color Research \& Application, 23(6), $390-401$.

Campbell, C. (2005). The Craft Consumer: Culture, craft and consumption in a postmodern society. Journal of Consumer Culture, 5(1), 23-42.

Campbell, M. C. (1995). When Attention-Getting Advertising Tactics Elicit Consumer Inferences of Manipulative Intent: The Importance of Balancing Benefits and Investments. Journal of Consumer Psychology, 4(3), 225-254.

Canclini, N. G. (1999). O consumo serve para pensar. In Consumidores e Cidadãos: conflitos multiculturais da globalização (4th ed., pp. 75-94). Rio de Janeiro: Editora UFRJ.

Carrefour. (2017). Carrefour - Melhor site de compras online. Acesso em 10 de novembro, 2017, de https://www.carrefour.com.br/

Castells, M. (1999). Era da Informação: economia, sociedade e cultura (vol 3). São Paulo: Paz e terra.

CBS News. (2017). Colored Ketchup - Epic, embarrassing product failures. Acesso em 31 de outubro, 2017, de https://www.cbsnews.com/pictures/epic-embarrassing-product-failures/8/

Chandon. (2017). Verão Chandon. Disponível em https://www.wine.com.br/wineinfo/landingpage/especial/verao-chandon/

Chaves, N. (2014). Marca cromática e a semântica da cor. Acesso em 4 de novembro, 2016, de http://foroalfa.org/articulos/marca-cromatica-e-semantica-da-cor

Chen, Y.-S., \& Chang, C.-H. (2013). Greenwash and Green Trust: The Mediation Effects of Green Consumer Confusion and Green Perceived Risk. Journal of Business Ethics, 114(3), 489-500.

Cherry, M. A., \& Sneirson, J. F. (2011). Beyond Profit: Rethinking Corporate Social Responsibility and Greenwashing After the BP Oil Disaster. Tulane Law Review, 85(4), 983-1039. 
Chevreul, M. E. (1860). The Principles of Harmony and Contrast of Colours, and Their Applications to the Arts (3rd ed.). London: H. G. Bohn. Disponível em https://goo.gl/2xmJTA

Child, I. L., Hansen, J. A., \& Hornbeck, F. W. (1968). Age and Sex Differences in Children's Color Preferences. Child Development, 39(1), 237.

Cialdini, R. B. (2001). Influence: science and practice (4th ed.). Needham Heights, MA: Allyn \& Bacon.

Clydesdale, F. M. (1993). Color as a factor in food choice. Critical Reviews in Food Science \& Nutrition, 33(1), 83-101.

CNN Money. (2002, 20 de junho). M\&M's lovers pick purple. CNN Money. New York. Disponível em http://money.cnn.com/2002/06/20/news/companies/mandms/

Coca-Cola Company. (2011). Coca-Cola Holiday Cans - 12 OZ. Can Fact Sheet. Atlanta.

Disponível em https://www.coca-

colacompany.com/content/dam/journey/us/en/private/fileassets/pdf/2011/11/Coca-Cola_DKOFact-Sheet.pdf

Cola-Cola Company. (2016). Coca-Cola i ny kostym. Acesso em 14 de dezembro, 2017, de https://www.coca-cola.se/stories/coca-cola-i-ny-kostym

Collins, L. (2011, março). Sole Mate: Christian Louboutin and the psychology of shoes. The New Yorker - Condé Nast. Disponível em https://www.newyorker.com/magazine/2011/03/28/solemate

Collins, P. (2012, 11 de agosto). Mo Farah wins gold in 5000m at London 2012 Olympics. Daily Mail Online. London. Disponível em http://www.dailymail.co.uk/sport/olympics/article2187068/Mo-Farah-wins-gold-5000m-London-2012-Olympics.html

Cooper, G. (1996, 1 de abril). Pepsi turns air blue as color wars reach for the sky. The Independent. London. Disponível em www.independent.co.uk/news/pepsi-turns-air-blue-as-cola-warsreach-for-sky-1302822.html.

Cooper, G. (2012, 12 de julho). Testing the latest craze - painting your own Louboutins. The Telegraph. London. Disponível em http://www.telegraph.co.uk/lifestyle/interiors/9396389/Testing-the-latest-craze-painting-yourown-Louboutins.html

Costa, J. (2011). A imagem da marca: um fenômeno social. São Paulo: Rosari.

Creusen, M. E. H., \& Schoormans, J. P. L. (2005). The Different Roles of Product Appearance in Consumer Choice. Journal of Product Innovation Management, 22(1), 63-81.

Crowley, A. E. (1993). The two-dimensional impact of color on shopping. Marketing Letters, 4(1), 59-69. https://doi.org/10.1007/BF00994188

Crozier, W. R. (1999). The meanings of colour: preferences among hues. Pigment \& Resin Technology, 28(1), 6-14.

Csaba, F. F., \& Bengtsson, A. (2006). Rethinking identity in brand management. In J. Schroeder \& 
M. S. Morling (Eds.), Brand culture (pp. 118-135). London: Routledge.

Daily Mail. (2012, 17 de outubro). YSL drops 18-month lawsuit against Christian Louboutin as both sides claim they won battle of the red-soled shoes. Mail Online. London. Disponível em http://www.dailymail.co.uk/femail/article-2219103/YSL-drops-18-month-lawsuit-ChristianLouboutin-sides-claim-won-battle-red-soled-shoes.html

Danone. (2017). Danone. Acesso em 10 de novembro, 2017, de http://corporate.danone.com.br/br/home/

Dean, S. (2015, 31 de março). Coca-Cola accused of "health washing" because a can of Coke Life has 6 teaspoons of sugar. Daily Mail Online. Disponível em http://www.dailymail.co.uk/news/article-3018850/Coca-Cola-accused-health-washing-singleCoke-Life-maxes-daily-recommended-SIX-teaspoons-sugar.html

Decker, A., \& Elliott, D. (2011). Media Myths and Breast Cancer. In S. D. Ross \& P. M. Lester (Eds.), Images that injure (3rd ed., pp. 260-273). Santa Barbara.

DeGeneres, E. (2012). Bic Pens for Women. The Ellen Show. USA: NBC. Disponível em https://www.youtube.com/watch?v=eCyw3prIWhe

Deighton, J. A. Dove: Evolution of a Brand. Harvard Business School Case 508-047 (2007).

Denzin, N. K. (2012). Triangulation 2.0. Journal of Mixed Methods Research, 6(2011), 80-88.

Dezan, A. (2010, 26 de junho). Em Parintins, marcas mudam de cor por causa dos bois. Portal iG Brasil Econômico. Parintins. Disponível em http://economia.ig.com.br/empresas/em-parintinsmarcas-mudam-de-cor-por-causa-dos-bois/n1237684561581.html

Dondis, D. A. (1991). Sintaxe da linguagem visual. São Paulo: Martins Fontes.

Douglas, M., \& Isherwood, B. C. (1996). he world of goods: an anthropological approach to consumption. London \& New York: Routledge.

Dove. (2017). Bem vindos ao site de Dove. Acesso em 29 de novembro, 2017, de http://www.dove.com/br/home.html

Ellen, P. S., Webb, D. J., \& Mohr, L. A. (2006). Building Corporate Associations: Consumer Attributions for Corporate Socially Responsible Programs. Journal of the Academy of Marketing Science, 34(2), 147-157.

Elliot, A. J., \& Maier, M. A. (2012). Color-in-Context Theory. Advances in Experimental Social Psychology (1st ed., Vol. 45). Elsevier Inc.

Etgar, M. (2008). A descriptive model of the consumer co-production process. Journal of the Academy of Marketing Science, 36(1), 97-108.

Fara, P. (2015). Newton shows the light: a commentary on Newton (1672) "A letter ... containing his new theory about light and colours..." Philosophical Transactions of the Royal Society A: Mathematical, Physical and Engineering Sciences, 373(2039), 20140213-20140213.

Feloni, Ri. (2016, 7 de julho). The creator of Crystal Pepsi says it's probably the greatest idea he's 
ever had — and its failure taught him an important lesson. Business Insider. New York. Disponível em http://www.businessinsider.com/crystal-pepsi-creator-david-novak-its-failuretaught-important-lesson-2016-7

Feltman, R., \& Elliot, A. J. (2011). The Influence of Red on Perceptions of Relative Dominance and Threat in a Competitive Context. Journal of Sport and Exercise Psychology, 33(2), 308-314.

Fiordo, R. A. (1977). Charles Morris and the criticism of discourse. Bloomington.

Flick, U. (2004). Triangulation in Qualitative Research. In U. Flick, E. von Kardoff, \& I. Steinke (Eds.), A companion to qualitative research (pp. 178-183). London: Sage Publications.

Floch, J.-M. (2000). Visual identities. London: Continuum International Publishing Group.

Flusser, V. (2007). O mundo codificado: por uma filosofia do design e da comunicação. São Paulo: Cosac Naify.

Forbes Agency Concil. (2017, 25 de agosto). Finding Brand Success In The Digital World. Forbes. Disponível em https://www.forbes.com/sites/forbesagencycouncil/2017/08/25/finding-brandsuccess-in-the-digital-world/\#7d9bc6fe626e

Fraccaroli, C. (1952). A percepção da forma e sua relação com o fenômeno artístico-o problema visto através da Gestalt (psicologia da forma). São Paulo: FAUUSP.

FutureBrand. (2012). American Airlines. Acesso em 12 de março, 2017, de https://www.futurebrand.com/our-work/american-airlines

FutureBrand. (2016). Manual de Marca Oi - Guia de Identidade Visual e Verbal. Rio de Janeiro.

Gage, J. (1999). Color and Meaning: art, science, and symbolism. London: Thames \& Hudson.

Gage, J. (2012). A cor na arte. São Paulo: WMF Martins Fontes.

Garber, J. L. L., Burke, R. R., \& Jones, J. M. (2000). The Role of Package Color in Consumer Purchase Consideration and Choice. Marketing Science Institute Working Paper Series, $\mathrm{OO}_{-}$ 104.

Garber Jr., L. L., \& Hyatt, E. M. (2003). Color as a tool for visual persuasion. In L. M. Scott \& R. Batra (Eds.), Persuasive imagery: A consumer response perspective (Advertising and consumer psychology) (pp. 313-336). Mahwah, N.J.: Lawrence Erlbaum Associates.

Garber Jr., L. L., Hyatt, E. M., \& Starr, R. G. (2003). Measuring consumer response to food products. Food Quality and Preference, 14(1), 3-15.

Glamurama. (2017, dezembro). Ultra Violet: como usar a cor eleita pela Pantone para 2018 na maquiagem? Uol. Disponível em https://glamurama.uol.com.br/ultra-violet-como-usar-a-coreleita-pela-pantone-para-2018-na-maquiagem/

Goddard, J. (2011, 3 de dezembro). Coca Cola drops "polar bear" cans because consumers prefer to see red - Telegraph. The Telegraph. London. Disponível em http://www.telegraph.co.uk/foodanddrink/foodanddrinknews/8933476/Coca-Cola-dropspolar-bear-cans-because-consumers-prefer-to-see-red.html 
Goethe, J. W. von. (1993). Doutrina das Cores. (M. G. Tradução, Ed.). São Paulo: Nova Alexandria.

Golliff, B. (2013). The 10 Most Significant Colors in Sneaker History. Acesso em 15 de novembro, 2017, de http://www.complex.com/sneakers/2013/07/10-most-significant-colors-in-sneakerhistory/

Gombrich, E. H. (1949). Reviewed Work: Signs, Language and Behavior by Charles Morris. The Art Bulletin, 31(1), 68-73.

Gorman, D. E. (2012). Protecting Single Color Trademarks in Fashion after Louboutin. Cardozo Arts \& Entertainment Law Journal, 30.

Gorn, G. J., Chattopadhyay, A., Sengupta, J., \& Tripathi, S. (2004). Waiting for the web: how screen color affects time perception. Journal of Marketing Research, 41(2), 215-225.

Gorn, G. J., Chattopadhyay, A., Yi, T., \& Dahl, D. W. (1997). Effects of Color as an Executional Cue in Advertising: They're in the Shade. Management Science, 43(10), 1387-1400.

Greenpeace. (2008). Introduction to StopGreenwash.org. Acesso em 15 de junho, 2016, de http://www.stopgreenwash.org/introduction

Grewach, L. D. (1985). In Re Owens-Corning Fiberglas Corp.: The Federal Circuit Puts OwensCorning in the Pink. American University Law Review, 35.

Grossman, R. P., \& Wisenblit, J. Z. (1999). What we know about consumers' color choices. Journal of Marketing Practice: Applied Marketing Science, 5(3), 78-88.

Guimarães, L. (2000). A cor como informação - a consrução biofísica, linguística e cultural da simbologia das cores (3rd ed.). São Paulo: Annablume.

H\&M. (2017). More life, more colours with Danish stylist Emili Sindlev. Acesso em 31 de janeiro, 2018, de http://www2.hm.com/en_asia2/life/fashion/everyday-icon/more-life--more-colourswith-danish-stylist-emili-sindlev.html

H\&M. (2018). Pretty in pastels. Acesso em 31 de janeiro, 2018, de http://www2.hm.com/en_asia2/life/fashion/editors-picks/pretty-in-pastels.html

Haig, M. (2003). Brand failures: the truth about the 100 biggest branding mistakes of all time. London: Kogan Page.

Hallahan, K., Holtzhausen, D., van Ruler, B., Verčič, D., \& Sriramesh, K. (2007). Defining Strategic Communication. International Journal of Strategic Communication, 1(1), 3-35.

Hancock, J. R. (2014). Por que rosa é de menina e azul é de menino? Acesso em 19 de março, 2017, de http://brasil.elpais.com/brasil/2014/11/18/ciencia/1416328918_518343.html

Harrison, J. (2014). Responsive logos. Acesso em 22 de abril, 2016, de http://responsivelogos.co.uk/

Harvey, D. (1992). Condição Pós-Moderna: uma pesquisa sobre as origens da mudança cultural. São Paulo: Edições Loyola. 
Heidi. (2018). Heidi Chocolat. Acesso em 9 de fevereiro, 2017, de http://www.heidi-chocolat.at/

Heineken. (2005). Heineken Visual Brand Identity - Building the Heineken Brand. Amsterdam.

Heller, E. (2004). Psicología del color. Gustavo Gili.

Henderson, J. M., Brockmole, J. R., Castelhano, M. S., \& Mack, M. (2007). Visual Saliency Does Not Account for Eye Movements During Visual Search. In R. P. G. van Gompel, M. H. Fischer, W. S. Murray, \& R. L. Hill (Eds.), Eye movements: A window on mind and brain (pp. 537-562). Chicago: Elsevier.

Hill, J. J. (1957). Reviewed Work: Signs, Language, and Behavior, by Charles Morris. The Quarterly Review of Biology, 32(1), 85-85.

Holbrook, M. B. (1987). The Study of Signs in Consumer Esthetics: An Egocentric Review. In J. U. Sebeok (Ed.), Marketing and Semiotics: New Directions in the Study of Signs for Sale (pp. 73121). Berlin; New York: Walter de Gruyter.

Holbrook, M. B., \& Hirschman, E. C. (1993). The semiotics of consumption: Interpreting symbolic consumer behavior in popular culture and works of art (vol. 110). Chicago: Walter de Gruyter.

Holt, D. B. (2002). Why Do Brands Cause Trouble? A Dialectical Theory of Consumer Culture and Branding. Journal of Consumer Research, 29(1), 70-90.

Hubel, D. H. (1995). Eye, brain, and vision. New York: Scientific American Library/Scientific American Books.

Huffington Post. (2012). Limited Edition You Pick M\&amp;M’s Mix Features Pink, Purple, Aqua Chocolates. Huffington Post. New York. Disponível em https://www.huffingtonpost.com/2012/12/11/limited-edition-mm_n_2277302.html

Hurlbert, A. C., \& Ling, Y. (2007). Biological components of sex differences in color preference. Current Biology, 17(16).

Hutchison, C. (2010, 24 de abril). KFC Fights Breast Cancer with Fried Chicken. ABC News Online. Disponível em http://abcnews.go.com/Health/Wellness/kfc-fights-breast-cancer-friedchicken/story?id=10458830

Interbrand. (2011). Color turns a monopoly into a brand of choice. Acesso em 5 de fevereiro, 2016, de http://interbrand.com/work/color-turns-a-monopoly-into-a-brand-of-choice/

Itaú. (2006). Inconfundivel. Brasil: Agência Africa. Disponível em $\mathrm{https}: / / \mathrm{www}$.youtube.com/watch?v=2sQJroZaWQ0

Itaú. (2012). Saiba aqui como o banco feito para você se tingiu de laranja. Acesso em 22 de abril, 2016, de https://www.itau.com.br/sobre/marca/saiba-aqui-como-o-banco-feito-para-voce-setingiu-de-laranja.html

Itaú. (2017a). Apresentação Institucional 3T17. São Paulo. Disponível em www.itau.com.br/relacoes-com-investidores

Itaú. (2017b). Banco Itaú - Feito Para Você. Acesso em 10 de dezembro, 2017, em 
www.itau.com.br

Itaú. (2017c). Bike Itaú. Acesso em 10 de dezembro, 2017, de https://bikeitau.com.br

Itaú. (2017d). Revista Itaú online. Acesso em 10 de dezembro, 2017, de ww2.itau.com.br/hotsites/itau/carreira/revista

Iyengar, S. S., \& Lepper, M. R. (1999). Rethinking the value of choice: A cultural perspective on intrinsic motivation. Journal of Personality and Social Psychology, 76(3), 349-366.

Iyengar, S. S., \& Lepper, M. R. (2000). When choice is demotivating: Can one desire too much of a good thing? Journal of Personality and Social Psychology, 79(6), 995-1006.

Jain, S. P., \& Posavac, S. S. (2004). Valenced Comparisons. Journal of Marketing Research, 41(1), $46-58$.

Johnson, B. (1999). iMac: Steve Jobs. Acesso em 10 de junho, 2016, de http://adage.com/article/news/imac-steve-jobs/61998/

Johnstone, H. W. (1973). Reviewed Works: Writings on the General Theory of Signs by Charles Morris. Philosophy and Phenomenological Research, 33(4), 579-581. Disponível em http://www.jstor.org/stable/2106547

Joudrey, D. N., Taylor, A. G., \& Wisser, K. M. (2017). The organization of information (4th ed.). Santa Barbara: ABC-CLIO.

Kahn, B. E., \& Ratner, R. K. (2005). Variety for the sake of variety? Diversification motives in consumer choice. In S. Ratneshwar \& D. G. Mick (Eds.), Inside consumption: consumer motives, goals, and desires. London and New York: Routledge.

Kahn, B. E., \& Wansink, B. (2004). The Influence of Assortment Structure on Perceived Variety and Consumption Quantities. Journal of Consumer Research, 30(4), 519-533.

Kapferer, J.-N. (2012). The New Strategic Brand Management: advanced insights and strategic thinking. London: Kogan Page.

Karjalainen, T.-M. It looks like a Toyota: Educational approaches to designing for visual brand recognition, 1International Journal of design 67-81 (2007).

Karjalainen, T.-M., \& Snelders, D. (2010). Designing visual recognition for the brand. Journal of Product Innovation Management, 27(1), 6-22.

Kaya, N., \& Epps, H. H. (2004). Relationship between color and emotion: a study of college students. College Student Journal, 38(3), 396-405.

Keller, K. L. (1998). Strategic Brand Management: building, measuring and managing brand equity. New Jersey: Prentice Hall.

Keller, K. L. (2015). Designing and implementing brand architecture strategies. Journal of Brand Management, 21(9), 702-715.

Keller, K. L. (2016). Unlocking the Power of Integrated Marketing Communications: How 
Integrated Is Your IMC Program? Journal of Advertising, 45(3), 286-301.

Keller, R. (2013). Doing discourse research: an introduction for social scientists. London: Sage.

Kelly, B. (2010). How do colors affect purchases? Acesso em 9 de janeiro, 2018, de https://blog.kissmetrics.com/color-psychology/

Kenney, K. R. (2010). Visual Communication Research Designs. New York: Routledge.

Kentucky Fried Chicken. (2006). KFC International - Brand Identity Standards. Louisville, KY: Yum Brands.

Kim, H., \& Markus, H. R. (1999). Deviance or uniqueness, harmony or conformity? A cultural analysis. Journal of Personality and Social Psychology, 77(4), 785-800.

Klein, J. G., Smith, N. C., \& John, A. (2004). Why We Boycott: Consumer Motivations for Boycott Participation. Journal of Marketing, 68(3), 92-109.

Klein, N. (2004). Marcas globais e poder corporativo. In D. de Moraes (Ed.), Por uma outra comunicação: mídia, mundialização cultural e poder (2nd ed.). Rio de Janeiro: Record.

Koller, V. (2008). 'Not just a colour': pink as a gender and sexuality marker in visual communication. Visual Communication, 7(4), 395-423.

Kopp, R. (2002). Design gráfico cambiante: a instabilidade como regra. Revista FAMECOS, 1(18).

Kramer, T., \& Block, L. (2008). Conscious and Nonconscious Components of Superstitious Beliefs in Judgment and Decision Making. Journal of Consumer Research, 34(6), 783-793.

Kress, G., \& Van Leeuwen, T. (2002). Colour as a semiotic mode: notes for a grammar of colour. Visual Communication, 1(3), 343-368.

Kreutz, E. de A. (2007). Identidade Visual Corporativa Mutante: uma estratégia comunicacional contemporânea. In XXX Congresso Brasileiro de Ciências da Comunicação (p. 15). Santos: Intercom - Sociedade Brasileira de Estudos Interdisciplinares da Comunicação.

Kuehni, R. G. (2003). Color space and its divisions: color order from antiquity to the present. Hoboken, NJ: John Wiley \& Sons.

Kuehni, R. G. (2012). Color: an introduction to practice and principles (3rd ed.). Hoboken, NJ: John Wiley \& Sons.

Kuehni, R. G., \& Schwarz, A. (2008). Color ordered: a survey of color order systems from antiquity to the present. New York: Oxford University Press.

Kunsch, M. M. K. (2009). Percursos paradigmáticos e avanços epistemológicos nos estudos da comunicação organizacional. In M. M. K. Kunsch (Ed.), Comunicação organizacional - vol. 1: histórico, fundamentos e processos (pp. 63-89). São Paulo: Saraiva.

Kunsch, M. M. K. (2014). Comunicação Organizacional: contextos, paradigmas e abrangência conceitual. MATRIZes, 8(2), 35-61. 
Labrecque, L. I., \& Milne, G. R. (2012). Exciting red and competent blue: the importance of color in marketing. Journal of the Academy of Marketing Science, 40(5), 711-727.

Labrecque, L. I., \& Milne, G. R. (2013). To be or not to be different: Exploration of norms and benefits of color differentiation in the marketplace. Marketing Letters, 24(2), 165-176.

Labrecque, L. I., Patrick, V. M., \& Milne, G. R. (2013). The Marketers' Prismatic Palette: A Review of Color Research and Future Directions. Psychology \& Marketing, 30(2), 187-202.

Lacey, M. de. (2012, 11 de julho). DIY Louboutins? Sales of red tester paint pots soar as women create homemade versions of stars' favourite shoes. Daily Mail Online. London. Disponível em http://www.dailymail.co.uk/femail/article-2171399/Sales-red-tester-paint-pots-soarwomen-create-homemade-Louboutin-copies.html

Landor. (2010). Brand as a beacon of change - BP Case study. Acesso em 8 de novembro, 2017, de https://landor.com/work/bp

Lans, R. van der, Pieters, R., \& Wedel, M. (2008). Competitive Brand Salience. Marketing Science, 27(5), 922-931.

Lavidge, R. J., \& Steiner, G. A. (1961). A Model for Predictive Measurements of Advertising Effectiveness. Journal of Marketing, 25(6), 59-62.

Lee, N. Y., Noble, S. M., \& Biswas, D. (2016). Hey big spender! A golden (color) atmospheric effect on tipping behavior. Journal of the Academy of Marketing Science, (Geboy 1996).

Lei da Propriedade Industrial n ${ }^{\circ} 9.279$ (1996). Brasil: Instituto Nacional da Propriedade Industrial. Disponível em http://www.planalto.gov.br/ccivil_03/leis/L9279.htm

Lencastre, P. de. (2007). A marca: o sinal, a missão e a imagem. In P. de Lencastre (Ed.), O livro da marca (pp. 23-71). Lisboa: Dom Quixote.

Lennie, P. (2000). Color Vision. In E. R. Kandel, J. H. Schwartz, \& T. M. Jessell (Eds.), Principles of neural science (4th ed., pp. 572-589). New York: McGraw-Hill.

Lent, R. (2004). Cem bilhões de neurônios: conceitos fundamentais de neurociência. São Paulo: Atheneu.

Lightfoot, C., \& Gerstman, R. (1998). Brand packaging. In Brands: the new wealth creators. NYU Press.

Lindstrom, M. (2005). Brand Sense: How to build powerful brands through touch, taste, smell, sight and sound. New York: Free Press.

Lindt. (2015). Chocolats Lindt France. Acesso em 9 de fevereiro, 2017, de http://www.lindt.fr/

Linhares, J. M. M., Pinto, P. D., \& Nascimento, S. M. C. (2008). The number of discernible colors in natural scenes. Journal of the Optical Society of America, 25(12), 2918-2924.

Lipovetsky, G., \& Sebastien, C. (2004). Os tempos hipermodernos. São Paulo: Barcarolla.

Louboutin, C. (2017). Louboutin online shop - women. 
Lusch, R. F., \& Vargo, S. L. (2006). Service-dominant logic: reactions, reflections and refinements. Marketing Theory, 6(3), 281-288.

Lüscher, M., \& Scott, I. A. (1971). The Lüscher color test. New York: Pocket Books.

M\&M's. (2016). Characters. Acesso em 19 de janeiro, 2018, de http://www.mms.com/us/characters

M\&M - Mars. (2017). Design your own M\&M's. Acesso em 23 de novembro, 2017, de https://www.mymms.com/configurator.do?customerType=B2C

Mai, R., Symmank, C., \& Seeberg-Elverfeldt, B. (2016). Light and Pale Colors in Food Packaging: When Does This Package Cue Signal Superior Healthiness or Inferior Tastiness? Journal of Retailing.

Markus, H. R., \& Schwartz, B. (2010). Does Choice Mean Freedom and Well-Being? Journal of Consumer Research, 37(2), 344-355.

Material Designs. (2009). Secret of Apple's Design. Acesso em 9 de janeiro, 2018, de https://materialdesigns.wordpress.com/2009/08/06/material-design-secret-of-apples-design/

Mazumdar, A. (2015, 20 de outubro). John Deere colors might be aesthetically functional. Bloomberg BNA. Washington, D.C. Disponível em http://www.bna.com/john-deere-colorsn57982059682/

McCracken, G. (1986). Culture and Consumption: A Theoretical Account of the Structure and Movement of the Cultural Meaning of Consumer Goods. Journal of Consumer Research, 13(1), 71 .

McCracken, G. (1993). The value of the brand: an anthropological perspective. In D. A. Aaker \& A. L. Biel (Eds.), Brand equity \& advertising: advertising's role in building strong brands (pp. 125-142). Hilladale, NJ: Lawrence Erlbaum Associates.

McGuire, W. J. (1978). An information-processing model of advertising effectiveness. In H. J. Davis \& J. Silk, Alvin (Eds.), Behavioral and management science in marketing (pp. 156180). New York: Ronald Press.

Mead, G. H. (1972). Mind, self and Mind, Self and Society from the Standpoint of a Social Behavioris (8th ed.). Chicago: University of Chicago Press.

Mead, J. A., \& Richerson, R. (2018). Package color saturation and food healthfulness perceptions

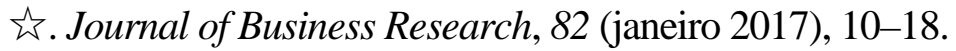

Meht, R., \& Zhu, R. (2009). Blue or red? Exploring the effect of color on cognitive task performances. Science, 323(5918), 1226-1229.

Mick, D. G. (1986). Consumer Research and Semiotics: Exploring the Morphology of Signs, Symbols, and Significance. Journal of Consumer Research, 13(2).

Mick, D. G. (1997). Semiotics in marketing and consumer research. In S. Brown \& D. Turley (Eds.), Consumer research: postcards from the edge. (pp. 244-256). London: Routledge.

Miles, M. B., \& Huberman, A. M. (1994). Qualitative Data Analysis: an expanded sourcebook. 
Thousand Oaks, California: Sage.

Miletsky, J. I., \& Smith, G. (2009). Perspectives on Branding. Boston: Cengage Learning.

Miller, M. J. (2015). Coca-Cola Adopts One-Brand Strategy in Europe and the US to Clear Up Confusion. Acesso em 14 de dezembro, 2017, de http://brandchannel.com/2015/03/05/cocacola-adopts-one-brand-strategy-in-europe-and-the-us-to-clear-up-confusion/

Milosavljevic, M., Navalpakkam, V., Koch, C., \& Rangel, A. (2012). Relative visual saliency differences induce sizable bias in consumer choice. Journal of Consumer Psychology, 22(1), $67-74$.

Moller, A. C., Elliot, A. J., \& Maier, M. A. (2009). Basic hue-meaning associations. Emotion, 9(6), 898-902. https://doi.org/10.1037/a0017811

Moreau, C. P., \& Herd, K. B. (2010). To Each His Own? How Comparisons with Others Influence Consumers' Evaluations of Their Self-Designed Products. Journal of Consumer Research, 36 (fevereiro), 806-819.

Morris, C. W. (1938). Foundations of the theory of signs. (O. Neurath, Ed.) (Internatio). Chicago: The University of Chicago Press.

Morris, C. W. (1946). Signs, language and behavior. New York: Prentice-Hall.

Morris, C. W. (1964). Signification and significance: a study of the relations of signs and values. Cambridge: M.I.T. Press, Massachusetts Institute of Technology.

Morris, C. W. (1993). Symbolism and reality : a study in the nature of mind. Foundations of semiotics. Amsterdam/Philadelphia: John Benjamins Publishing.

Moye, J. (2016). Noma Bar Adds Graphic Touch to Coca-Cola Polar Bears in Holiday Packaging Designs. Acesso em 25 de outubro, 2017, de http://www.coca-colacompany.com/stories/polarbears-return-to-coca-cola-holiday-packaging

Mozeglio, É. (1972). Interpretação do significado de módulo-cor: contribuição ao estudo da cor e sua aplicação na programação de mensagens visuais. Universidade de São Paulo.

Müller, M. G. (2007). What is visual communication? Studies in Communication Sciences, 7(2), 734.

Munsell. (1929). Munsell Book of Color: defining, explaining, and illustrating the fundamental characteristics of color. Baltimore, MD.

Nedungadi, P. (1990). Recall and Consumer Consideration Sets: Influencing Choice without Altering Brand Evaluations. Journal of Consumer Research, 17(3), 263.

Net-a-porter. (2017). Net-a-porter. Disponível em www.net-a-porter.com

Newton, S. I. (1718). Opticks: or, a treatise of the reflections, refractions, inflections and colours of light (2nd ed.). London: William and John Innys. Disponível em https://goo.gl/UpJCpU

Niemann, G. (2007). Big Brown: The Untold Story of UPS. New Jersey: John Wiley and Sons. 
Nike. (2018). Nike and the swoosh. Acesso em 19 de janeiro, 2018, de http://helpus.nikeinc.com/app/answers/detail/a_id/497/ /nike-and-the-swoosh

Nöth, W. (1990). Handbook of Semiotics Advances in Semiotics. (T. A. Sebeok, Ed.), Advances in semiotics. Bloomington and Indianapolis: Indiana University Press.

Nubank. (2017). Nubank - Finalmente você no controle do seu dinheiro. Acesso em 10 de dezembro, 2017, de https://www.nubank.com.br/

Nuffield Council on Bioethics. (2015). Ideas about naturalness in public and political debates about science, technology and medicine - analysis paper. London. Disponível em http://nuffieldbioethics.org/wp-content/uploads/Naturalness-analysis-paper.pdf

O Globo. (2015, 3 de setembro). Collor fez convocação em 1992 e impulsionou impeachment. Jornal O Globo - Versão Online. Rio de Janeiro. Disponível em https://oglobo.globo.com/brasil/collor-fez-convocacao-em-1992-impulsionou-impeachment17399532

Olins, W. (1990). Corporate identity: Making business strategy visible through design. Corporate identity: Making business strategy visible through design. Brighton, Massachusetts: Harvard Business School Press.

Olins, W. (2004). Wally Olins on brand. London: Thames \& Hudson.

Osgood, C. E. (1966). Reviewed Work: Signification and Significance: A Study of the Relations of Signs and Values, by Charles Morris. American Journal of Sociology, 71(5), 583-586. Disponível em http://www.jstor.org/stable/2774525

Ou, L.-C., Luo, M. R., Woodcock, A., \& Wright, A. (2004a). A study of colour emotion and colour preference. Part I: Colour emotions for single colours. Color Research \& Application, 29(3), 232-240.

Ou, L.-C., Luo, M. R., Woodcock, A., \& Wright, A. (2004b). A study of colour emotion and colour preference. Part II: Colour emotions for two-colour combinations. Color Research \& Application, 29(4), 292-298.

Ou, L.-C., Luo, M. R., Woodcock, A., \& Wright, A. (2004c). A study of colour emotion and colour preference. Part III: Colour preference modeling. Color Research \& Application, 29(5), 381389.

Owens Corning. (2017). Color of the Year. Acesso em 19 de janeiro, 2018, de https://www.owenscorning.com/roofing/design-inspire/color-of-the-year

P\&G. (2017). P\&amp;G. Acesso em 10 de novembro, 2017, de https://br.pg.com/pt-BR

Pantone. (2017). Pantone Color, Chips \& Color Guides | Color Inspiration. Acesso em 10 de dezembro, 2017, de https://www.pantone.com/

Pão de Açúcar. (2017). Pão de Açúcar. Acesso em 7 de novembro, 2017, de https://www.paodeacucar.com/

Park, C. W., Jaworski, B. J., \& Maclnnis, D. J. (1986). Strategic brand concept-image management. 
The Journal of Marketing, 50(4), 135-145.

Parmar, A. (2004). Marketers ask: Hues on first? Marketing News, (Feb 15), 8-10.

Pastoureau, M. (2001). Blue: the history of a color. Princeton, NJ: Princeton University Press.

Pastoureau, M. (2006). Vers une histoire des couleurs : possibilités et limites. Communications Académie Des Beaux-Arts, 2005, 51-66.

Pastoureau, M. (2009). Black: the History of a color. Princeton, NJ: Princeton University Press.

Pastoureau, M. (2014). Green: the history of a color. Princeton, NJ: Princeton University Press.

Pastoureau, M. (2017). Red: the history of a color. Princeton, NJ: Princeton University Press.

Pastoureau, M., \& Simonnet, D. (2005). Le petit livre des couleurs. (E. du Panama, Ed.). Paris.

Paula, H. de F. (2012). Espectro eletromagnético. Acesso em 4 de janeiro, 2018, de http://pontociencia.org.br/galeria/\#/content/Fisica/Optica/Espectro Eletromagnetico.jpg

Pazda, A. D., Elliot, A. J., \& Greitemeyer, T. (2012). Sexy red: Perceived sexual receptivity mediates the red-attraction relation in men viewing woman. Journal of Experimental Social Psychology, 48(3), 787-790.

Pedrosa, I. (2008). O universo da cor. Rio de Janeiro: Senac Nacional.

Peñaloza, L., \& Thompson, A. (2014). Constructing the visual consumer. In E. Bell, S. Warren, \& J. Schroeder (Eds.), The Routledge companion to visual organization. New York: Routledge.

Personal. (2017). Personal VIP Black. Acesso em 31 de janeiro, 2018, de http://personalvipblack.com.br/

Perugina. (2016). Perugina.com: benvenuti nel Paese del Cioccolato Perugina. Acesso em 9 de fevereiro, 2017, de https://www.perugina.com/it

Pieters, R., Rosbergen, E., \& Wedel, M. (1999). Visual attention Repeated Print Advertising : A Test of Scanpath Theory. Journal of Marketing Research, 36(4), 424-438.

Pieters, R., \& Warlop, L. (1999). Visual attention during brand choice: The impact of time pressure and task motivation. International Journal of Research in Marketing, 16(1), 1-16.

Pilli, L. E. (2017). Multiple Goals-Based Choice: the evolution from homo economicus to homo aptabilis. Universidade de São Paulo.

Pinkwatching Israel. (2010). A global movement for queer-powered BDS. Acesso em 9 de novembro, 2017, de http://www.pinkwatchingisrael.com/

Politini, D. (2012). American Airlines - danielepolitini. Acesso em 1 de fevereiro, 2018, de http://danielepolitini.com/American-Airlines

Portal No Amazonas é Assim. (2013, 30 de junho). No ritmo do boi bumbá as marcas mudam de cores em Parintins. Parintins. Disponível em https://noamazonaseassim.com.br/no-ritmo-do- 
boi-bumba-as-marcas-mudam-de-cores-em-parintins/

Portilho, D. (2009). Registro de cor como marca. Revista UPpharma, 32(111), 60-61.

Posner, M. I., Nissen, M. J., \& Klein, R. M. (1976). Visual Dominance: An Information-Processing Account of Its Origins and Significance. Psychological Review, 83(2), 157-171.

Posner, R. (1987). Charles Morris and the Behavioral Foundations of Semiotics. In M. Krampen, K. Oehler, R. Posner, T. A. Sebeok, \& T. von Uexküll (Eds.), Classics of Semiotics (pp. 23-57). New York: Springer US.

Prado, L. (2017). Skolors - por pluralidade, Skol lança latas coloridas. Acesso em 18 de dezembro, 2017, de http://www.clubedecriacao.com.br/ultimas/skolors/

Purple. (2016). How 2 Brothers Invent The Most Comfortable Mattress Ever. Acesso em 18 de janeiro, 2018, de https://purple.com/about-us

Puzakova, M., Kwak, H., Ramanathan, S., \& Rocereto, J. F. (2016). Painting Your Point: The Role of Color in Firms' Strategic Responses to Product Failures via Advertising and Marketing Communications. Journal of Advertising, 3367 (agosto), 1-12.

Raig, B. M., \& Tybout, A. M. (2005). Brand extensions. In M. Tybout, Alice \& T. Calkins (Eds.), Kellogg on Branding (pp. 91-103). Hoboken, NJ: John Wiley and Sons.

Ratner, R. K., \& Kahn, B. E. (2002). The Impact of Private versus Public Consumption on VarietySeeking Behavior. Journal of Consumer Research, 29(2), 246-257.

Ravasi, D., \& Lojacono, G. (2005). Managing design and designers for strategic renewal. Long Range Planning, 38(1), 51-77.

Ray, M. L., Sawyer, A. G., Rothschild, M. L., Heeler, R. M., Strong, E. C., \& Reed, J. B. (1973). Marketing communication and the hierarchy-of-effects. In P. Clarke (Ed.), New Models for Mass Communication Research (Sage, pp. 147-175). Bervely Hills, CA: Sage.

Renova. (2017). Renova. Acesso em 23 de janeiro, 2018, de https://www.myrenova.com/

Ries, A., \& Ries, L. (2000). As 22 consagradas leis de marcas. São Paulo: Makron Books.

Riley, C. A. (1995). Color codes: Modern theories of color in philosophy, painting and architecture, literature, music, and psychology (University). Lebanon, $\mathrm{NH}$.

Romaniuk, J., \& Sharp, B. (2004). Conceptualizing and measuring brand salience. Marketing Theory, 4(4), 327-342.

Saito, M. (1996). Comparative studies on color preference in Japan and other Asian regions, with special emphasis on the preference for white. Color Research \& Application, 21(1), 35-49.

Santaella, L., \& Nöth, W. (2009). A linguagem das mercadorias. Signos Do Consumo, 1(1), 21-43.

Santos, J. (2015). Novos sinais do tempo na publicidade: sinais de um novo tempo nas dinâmicas sociais. In XXXVIII Congresso Brasileiro de Ciências da Comunicação. Rio de Janeiro: Intercom - Sociedade Brasileira de Estudos Interdisciplinares da Comunicação. 
Santos, J., \& Sato, S. K. (2009). Aplicação das macrotendências no gerenciamento das marcas contemporâneas. Revista Administração E Diálogo, 12(1), 46-58.

Santos, M. (2008). Por uma outra globalização: do pensamento único à consciência universal (17th ed.). Rio de Janeiro: Record.

Sato, S. K. (2016). Marcas e significados em movimento: da telefonia celular aos serviços convergentes de telecomunicações. In XXXIX Congresso Brasileiro de Ciências da Comunicação. São Paulo: Intercom - Sociedade Brasileira de Estudos Interdisciplinares da Comunicação.

Schepfler, H. (1975). Linguistics: Writings on the General Theory of Signs - Charles Morris. American Anthropologist, 77(1), 121-122.

Schmitt, B. H., \& Simonson, A. (2002). A estética do marketing: como criar e administrar sua marca, imagem e identidade. São Paulo: Nobel.

Schmitt, B. H., Simonson, A., \& Marcus, J. (1995). Managing corporate image and identity. Long Range Planning, 28(5), 82-92.

Schneier, M. (2017, novembro). At Tiffany, the Fifth Avenue Face-Lift Starts at Home. The New York Times - Online. New York. Disponível em https://www.nytimes.com/2017/11/07/style/tiffany-storetour.html?action=click\&contentCollection=Travel\&module=RelatedCoverage\&region=Margi nalia\&pgtype $=$ article

Schroeder, J. (2002). Visual consumption. London: Routledge.

Schroeder, J. (2009). The cultural codes of branding. Marketing Theory, 9(1), 123-126.

Schroeder, J. (2017). Corporate branding in perspective: a typology. European Journal of Marketing, 51(9/10), 1522-1529.

Schuldt, J. P. (2013). Does green mean healthy? Nutrition label color affects perceptions of healthfulness. Health Communication, 28 (maio 2015), 814-21.

Selikoff, J. (2007). The Real Thing. Really. Acesso em 25 de outubro, 2017, de https://www.underconsideration.com/brandnew/archives/the_real_thing_really.php

Semprini, A. (2000). A marca pós-moderna. São Paulo: Estação das Letras e Cores.

Sherry, J. J. (2005). Brand meaning. In M. Tybout, Alice \& T. Calkins (Eds.), Kellogg on Branding (pp. 40-69). Hoboken, NJ: John Wiley and Sons.

Shevell, S. K. (2003). Color Appearance. In S. K. Shevell (Ed.), The science of color (pp. 150-190). Elsevier.

Shopological. (2017). 13 millennial pink things to buy, just because. Acesso em 31 de janeiro, 2018, de https://www.shopological.com/article/millennial-pink-things-to-buy/

Simpson, J., Ohri, L., \& Lobaugh, K. M. (2016). The new digital divide: The future of digital influence in retail | Deloitte Insights. New York. Disponível em 
https://dupress.deloitte.com/dup-us-en/industry/retail-distribution/digital-divide-changingconsumer-behavior.html

Singh, S. (2006). Impact of Color on Marketing. Management Decision, 44(5), 783-789.

Skol. (2017). Skolors. Acesso em 10 de setembro, 2017, de https://www.skol.com.br/skolors

Smets, G. (1982). A tool for measuring relative effects of hue, brightness, and saturation on color pleasantness. Perceptual and Motor Skills, 55(3), 1159-614.

Smith, R. (2013, 19 de novembro). KFC turns flagship stores green and gold for Australian Ashes tilt. The Daily Telegraph Online. Disponível em https://www.dailytelegraph.com.au/newslocal/the-hills/kfc-turns-flagship-stores-green-andgold-for-australian-ashes-tilt/news-

story/2cdadf6c1f3f8c4cfb54c27e9e2db9b5?sv=81b245e5e05b6906b2440a1eac5f8ce

Souza, L. S. (2017). A circulação midiática na base da vida material: do consumo de marcação à marcação do consumo. Universidade de São Paulo.

Souza, S. (1992). Do conceito a imagem: fundamentos do design de pictogramas. Universidade de São Paulo.

Souza, S. (1995). Conteúdo, forma e função no design de pictogramas. In T. G. Corrêa (Ed.), Comunicação para o mercado: instituições, mercado, publicidade (pp. 171-192). São Paulo: Edicon.

Souza, S. (1997). Design, Marketing, Comunicação: particularidades e intersecções. Revista Comunicações E Artes, 20(30), 40-49.

Souza, S. (1999). Imagem gráfica e elementos da gramática visual. In T. G. Corrêa \& S. G. Freitas (Eds.), Comunicaçãom marketing, cultura: sentidos da administração, do trabalho e do consumo (pp. 123-138). São Paulo: ECA/USP, CLC.

Sport, R. (2018). Ritter Sport - Herzlich willkommen. Acesso em 9 de fevereiro, 2017, de https://www.ritter-sport.de/de/

Stead, C. (2013). Cricket fans take flight in KFC's green \& gold skybox - media release. Sydney.

Stewart, J. (2017, 13 de novembro). The Big Money Behind Naming A "Color Of The Year. Co.Design - Fast Company Magazine. Disponível em https://www.fastcodesign.com/90149703/the-big-money-behind-naming-a-color-of-the-year

Strauss, E. D., Schloss, K. B., \& Palmer, S. E. (2013). Color preferences change after experience with liked/disliked colored objects.

Strong, E. K. (1925). The psychology of selling and advertising. New York: McGraw-Hill.

Sundar, A., Gonsales, F. I., \& Sung-Hee, W. (2017). Role of color hues in signaling healthiness. In American Academy of Advertising (pp. 201-210). Boston.

Sundar, A., \& Kellaris, J. J. (2016). How Logo Colors Influence Shoppers' Judgments of Retailer Ethicality: the mediating role of perceived eco-friendliness. Journal of Business Ethics, 1-17. 
Susan G. Komen for the Cure. (2017). The pink ribbon story. Dallas. Disponível em https://ww5.komen.org/uploadedfiles/content_binaries/the_pink_ribbon_story.pdf

Taft, C. (1997). Color Meaning and Context: Comparisons of Semantic Ratings of Colors on Samples and Objects. Color Research \& Application, 22, 40-50.

Tangkijviwat, U., Rattanakasamsuk, K., \& Shinoda, H. (2010). Color preference affected by mode of color appearance. Color Research and Application, 35(1), 50-61.

Tátil Design de Ideias. (2013). Coca Cola - Copa das Confederações. Acesso em 10 de novembro, 2017, de http://tatil.com.br/pb/projetos/coca-cola-copa-das-confederacoes-2/

Telstra. (2012). Celebrating the first anniversary of the new Telstra brand. Acesso em 5 de fevereiro, 2016, de http://exchange.telstra.com.au/2012/09/19/celebrating-the-first-anniversary-of-thenew-telstra-brand/comment-page-1/

Telstra. (2018). Telstra - mobile phones, prepaid phones, broadband, internet, home phones, business phones. Acesso em 19 de janeiro, 2018, de https://www.telstra.com.au

Terwogt, M. M., \& Hoeksma, J. B. (1995). Colors and emotions: Preferences and combinations. The Journal of General Psychology, 122(1), 5-17.

Tessier-Lavigne, M. (2000). Visual Processing by the Retina. In E. R. Kandel, J. H. Schwartz, \& T. M. Jessell (Eds.), Principles of neural science (4th ed., pp. 507-522). New York: McGrawHill.

The Coca-Cola Company. (2011). Arctic Home Coke Cans and Diet Coke Holiday Cans: The Coca-Cola Company. Acesso em 25 de outubro, 2017, de http://www.cocacolacompany.com/press-center/company-statements/key-visual-elements-of-arctic-homecoke-cans-and-diet-coke-holiday-cans

The Coca-Cola Company. (2016). Coca-Cola Brasil lança estratégia para incentivar escolhas: reposicionamento da marca Coca-Cola inclui novas embalagens e reformulação da versão Zero Açúcar. Acesso em 14 de dezembro, 2017, de https://www.cocacolabrasil.com.br/imprensa/release/coca-cola-brasil-lanca-estrategia-paraincentivar-escolhas-reposicionamento-da-marca-coca-cola-inclui-novas-embalagens-ereformulacao-da-versao-zero-acucar

The Fashion Law. (2015). Louboutin is Facing Yet Another Battle Over its Red Sole Trademark. Acesso em 10 de junho, 2016, de http://www.thefashionlaw.com/louboutin-is-facing-yetanother-battle-over-its-red-sole-trademark/

The Guardian. (2012, 15vde fevereiro). "Pinkwashing": products sold to promote breast health. The Guardian Online - US News. Londo. Disponível em https://www.theguardian.com/world/gallery/2012/feb/15/pinkwashing-breast-health-komen

The Telegraph Online. (2012). Cash-strapped women are painting their shoe soles red to get the Louboutin look for less. The Telegraph. Disponível em http://fashion.telegraph.co.uk/newsfeatures/TMG9389255/Cash-strapped-women-are-painting-their-shoe-soles-red-to-get-theLouboutin-look-for-less.html

Tiffany \& Co. (2018). Tiffany \&amp; Co. Official | Luxury Jewelry, Gifts \&amp; Accessories 
Since 1837. Acesso em 19 de janeiro, 2018, de http://www.tiffany.com/

Tiffany \& Co. (2016). About Tiffany \& Co. - Tiffany Blue. Acesso em 6 de outubro, 2016, de http://press.tiffany.com/ViewBackgrounder.aspx?backgrounderId=6

Tintas Coral. (2017). Adorno Rupestre, a Cor do ano de 2018. Acesso em 24 de janeiro, 2018, de https://www.coral.com.br/cor-do-ano-de-2018

Trijp, H. C. M. Van, Hoyer, W. D., \& Inman, J. J. (1996). Why Switch? Product Category: Level Explanations for True Variety-Seeking Behavior. Journal of Marketing Research, 33(3), 281.

Trindade, E. (2006). Semiótica na comunicação publicitária: alguns pingos nos “is." ComCiência, 83(74), 1-3.

Trindade, E., \& Perez, C. (2014). Os rituais de consumo como dispositivos midiáticos para a construção de vínculos entre marcas e consumidores 1. Alceu, 15(29), 157-171.

TV UOL. (2012). Chandon Colors Collection by Silvia Cintra Franco. Brasil. Disponível em https://tvuol.uol.com.br/video/13418464/

Unilever. (2017). Centro de História Unilever - Dove. Acesso em 29 de novembro, 2017, de http://www.historiaunilever.com.br/unilever/timeline/produto/dove

Uol - Economia. (2015, 23 de fevereiro). Após vencer disputa contra Brahma, Itaipava lança cerveja em lata vermelha. São Paulo. Disponível em https://economia.uol.com.br/noticias/redacao/2015/02/23/apos-vencer-disputa-contra-brahmaitaipava-lanca-cerveja-em-lata-vermelha.htm

USA Today. (2003). Heinz unveils new blue ketchup. Acesso em 18 de março, 2017, de http://usatoday30.usatoday.com/money/industries/food/2003-04-07-blue-ketchup_x.htm

Vaisman, C. L. (2016). Pretty in pink vs pretty in black: blogs as gendered avatars. Visual Communication, 15(3), 293-315.

Valdez, P., \& Mehrabian, A. (1994). Effects of color on emotions. Journal of Experimental Psychology. General, 123(4), 394-409.

Valisere. (2015). Qual a sua cor para 2016? Acesso em 1 de novembro, 2017, de https://www.valisere.com.br/calcinhas-cores-ano-novo-reveillon

van Doorn, J., Lemon, K. N., Mittal, V., Nass, S., Pick, D., Pirner, P., \& Verhoef, P. C. (2010). Customer Engagement Behavior: Theoretical Foundations and Research Directions. Journal of Service Research, 13(3), 253-266.

van Leeuwen, T. (2005). Introducing social semiotics. London: Psychology Press.

Vit, A. (2011). Color me Colorful. Acesso em 5 de fevereiro, 2016, de http://www.underconsideration.com/brandnew/archives/color_me_colorful.php

Vivo. (2012). Manual da marca. São Paulo.

Voight, J. (2003, abril). Power of the palette: for many marketers, color has become a key to brand 
identity. ADWEEK, 44(17), 32-34. Disponível em http://www.adweek.com/brandmarketing/power-pallette-63666/

Wallace, R. (2016). Leadership Lessons from a UPS Driver: Delivering a Culture of We, Not Me. Oakland, CA: Berret-Koehler Publishers.

Walmart. (2009). Walmart brand guidelines. Bentonville, AR.

Walsh, L. M., Toma, R. B., Tuveson, R. V, \& Sondhi, L. (1990). Color preference and food choice among children. The Journal of Psychology, 124(6), 645-53.

Web Designer Depot. (2009). The Evolution of Apple Ads. Acesso em 10 de junho, 2016, de http://www.webdesignerdepot.com/2009/09/the-evolution-of-apple-ads/

Wertheimer, M. (1938). Special Problems: First Group: Perception, A. Perception and Organisation, Section 5: Laws of Organisation of Perceptual Forms. In W. D. Ellis (Ed.), A source book of Gestalt Psychology (pp. 71-88). London: Routledge \& Kegan Paul.

Wieden+Kennedy. (2013). Vamos juntos colorir o Brasil. Brasil: W+K São Paulo. Disponível em http://www.wksaopaulo.com.br/pt/trabalho/vamos-juntos-colorir-o-brasil

Williams, F. E. (2015). Green giants: How smart companies turn sustainability into billion-dollar businesses. New York: AMACOM.

Wolf Ollins, \& GAD'Desing. (2002). Manual de identidade visual da Oi. Acesso em 14 de dezembro, 2017, de https://brandingonline.wordpress.com/2016/03/29/manual-de-identidadevisual-da-oi/

Wurtz, R. H., \& Kandel, E. R. (2000). Perception of Motion, Depth, and Form. In E. R. Kandel, J. H. Schwartz, \& T. M. Jessell (Eds.), Principles of neural science (4th ed., pp. 548-571). New York: McGraw-Hill.

Yin, R. K. (2003). Case study research : design and methods. Applied social research methods series (3rd ed., Vol. 5). Thousand Oaks, California: SAGE Publications.

Zajonc, R. B. (1968). Attitudinal effects of mere exposure. Journal of Personality and Social Psychology, 9(2), 1-27.

Zipkin, P. (2001). The limits of mass customization. MIT Sloan Management Review, 42(3), 81-87.

Zollinger, H. (1999). Color: a multidisciplinary approach. Zürich: Verlag Helvetica Chimica Acta. 


\section{Apêndices}

\section{Apêndice A: Roteiro das entrevistas em profundidade, em inglês}

\begin{tabular}{|c|c|c|c|}
\hline & & $\begin{array}{l}\text { COMMUNICATORS, MANAGERS } \\
\text { (internal, employees) }\end{array}$ & $\begin{array}{c}\text { CONSULTANTS, DESIGNERS, } \\
\text { CREATIVES } \\
\text { (external, specialists) }\end{array}$ \\
\hline \multirow{3}{*}{ INTRO } & 1 & \multicolumn{2}{|c|}{ Present yourself and the doctoral project. Guarantee of anonymity. } \\
\hline & 2 & \multicolumn{2}{|c|}{ In your opinion, what have colors got to do with brands, in general? } \\
\hline & 3 & $\begin{array}{l}\text { What about [THE SPECIFIC } \\
\text { BRAND] and colors? }\end{array}$ & $\begin{array}{l}\text { Ask for examples, if he/she doesn't } \\
\text { give them spontaneously. }\end{array}$ \\
\hline \multirow{2}{*}{ MODES } & 4 - generic & $\begin{array}{l}\text { What about [THE SPECIFIC } \\
\text { BRAND]'s consumers? How do the } \\
\text { [BRAND] colors affect them? }\end{array}$ & $\begin{array}{c}\text { What about the colors and consumers } \\
\text { / consumption? How do you think } \\
\text { colors affect them? }\end{array}$ \\
\hline & 5 -specific & $\begin{array}{l}\text { Numbers, research, about what/how } \\
\text { do they think, feel, do about it } \\
\text { [THE BRAND COLORS]? }\end{array}$ & $\begin{array}{l}\text { Cases, if any: what/how do they think, } \\
\text { feel, do about it (color)? }\end{array}$ \\
\hline \multirow{5}{*}{ USES } & 6 - tactics & $\begin{array}{l}\text { Thinking about this... How does } \\
\text { [THE BRAND] use colors to provoke } \\
\text { the effects you've said? }\end{array}$ & $\begin{array}{l}\text { Thinking about this, what do you "do" } \\
\text { with colors, how do you use them to } \\
\text { provoke the effects? }\end{array}$ \\
\hline & $\begin{array}{l}7 \text { - if not } \\
\text { enough... }\end{array}$ & $\begin{array}{l}\text { How does [THE BRAND] uses } \\
\text { colors in... the } \\
\text { product/logo/POP/events? Give the } \\
\text { main example, if necessary }\end{array}$ & $\begin{array}{l}\text { Do you remember the briefing of any } \\
\text { special campaign? Who usually } \\
\text { decides to explore color intentionally? }\end{array}$ \\
\hline & 8 - example & Can you give me other examples? & $\begin{array}{l}\text { Can you give me other examples in } \\
\text { which you explored colors in those } \\
\text { ways? }\end{array}$ \\
\hline & 9 - strategy & $\begin{array}{l}\text { Did/Do you have any strategic goals } \\
\text { the use of colors? }\end{array}$ & $\begin{array}{l}\text { Which kind of instructions or strategic } \\
\text { goals did/do you receive? }\end{array}$ \\
\hline & 10 - measure & $\begin{array}{l}\text { Were they achieved? How did/do } \\
\text { you measure color success? } \\
\text { Ask for the results... }\end{array}$ & $\begin{array}{l}\text { Were the strategic goals achieved? } \\
\text { Which ones? Did the agency or client } \\
\text { measure the results? How? }\end{array}$ \\
\hline \multirow{3}{*}{$\begin{array}{l}\text { EXTRAS: } \\
\text { if you } \\
\text { have the } \\
\text { time and } \\
\text { openness }\end{array}$} & 11 - competition & $\begin{array}{c}\text { Can you recall any other brand that } \\
\text { explores color? What about [THE } \\
\text { BRAND] competitors? }\end{array}$ & $\begin{array}{l}\text { Can you recall any brand that explores } \\
\text { color in a special way? }\end{array}$ \\
\hline & 9 - specialization & \multicolumn{2}{|c|}{$\begin{array}{l}\text { In your undergraduate/specialization/MBA did you have any or class about } \\
\text { colors? Do you believe the subject should be [more] discussed? }\end{array}$} \\
\hline & $\begin{array}{l}10- \\
\text { recommendation }\end{array}$ & \multicolumn{2}{|c|}{$\begin{array}{l}\text { Can you recommend me (or make the bridge) other brand professionals that I } \\
\text { could interview? }\end{array}$} \\
\hline END & & \multicolumn{2}{|c|}{ Saying thank you } \\
\hline
\end{tabular}




\section{Apêndice B: Roteiro das entrevistas em profundidade, em português}

\begin{tabular}{|c|c|c|c|}
\hline & & $\begin{array}{l}\text { COMUNICADORES, GERENTES, } \\
\text { (time interno, funcionários) }\end{array}$ & $\begin{array}{c}\text { CONSULTORES, DESIGNERS, } \\
\text { CRIATIVOS } \\
\text { (especialistas, time externo) }\end{array}$ \\
\hline \multirow{3}{*}{ INTRO } & 1 & \multicolumn{2}{|c|}{ Apresente-se, apresente o projeto de doutorado. Garanta o anonimato. } \\
\hline & 2 & \multicolumn{2}{|c|}{ Na sua opinião, o que as cores têm a ver com as marcas, em geral? } \\
\hline & 3 & $\begin{array}{c}\text { E quanto a [MARCA ESPECÍFICA] } \\
\text { e as cores? }\end{array}$ & $\begin{array}{l}\text { Peça exemplos, se ele / ela não der } \\
\text { espontaneamente. }\end{array}$ \\
\hline \multirow{2}{*}{ MODOS } & $\begin{array}{l}4 \text { - Genérico, } \\
\text { aberto }\end{array}$ & $\begin{array}{c}\text { E quanto às cores e os } \\
\text { consumidores / consumo da } \\
\text { [MARCA]? Como você acha que as } \\
\text { cores da [MARCA] os afetam? }\end{array}$ & $\begin{array}{c}\text { E quanto às cores e os consumidores } \\
\text { / consumo? Como você acha que as } \\
\text { cores os afetam? }\end{array}$ \\
\hline & $\begin{array}{l}5 \text { - } \\
\text { Especificidades }\end{array}$ & $\begin{array}{c}\text { Números, pesquisas sobre o } \\
\text { que/como os consumidores pensam/ } \\
\text { se sentem/ agem em função das } \\
\text { cores da [MARCA]? }\end{array}$ & $\begin{array}{l}\text { Casos: o que / como os } \\
\text { consumidores pensam, sentem, } \\
\text { fazem sobre isso (cor)? }\end{array}$ \\
\hline \multirow{5}{*}{ usos } & 6 - Tática & $\begin{array}{c}\text { Pensando nisso... } \\
\text { Como a [MARCA] usa as cores para } \\
\text { provocar esses efeitos que você } \\
\text { citou? }\end{array}$ & $\begin{array}{l}\text { Pensando nisso, como você usa as } \\
\text { cores para provocar esses efeitos } \\
\text { desejados, que você citou? }\end{array}$ \\
\hline & $\begin{array}{l}7 \text {-Se não for } \\
\text { suficiente... }\end{array}$ & $\begin{array}{l}\text { Como a [MARCA] usa as cores no } \\
\text {.. produto, logo, embalagem, etc. } \\
\text { Fale o exemplo que principal da } \\
\text { marca/empresa, se preciso. }\end{array}$ & $\begin{array}{l}\text { Você se lembra de algum briefing } \\
\text { específico, de alguma campanha } \\
\text { especial...? Quem decide sobre o uso } \\
\text { intencional da cor, geralmente? }\end{array}$ \\
\hline & $\begin{array}{l}8 \text { - Mais } \\
\text { exemplos }\end{array}$ & Você pode me dar exemplos? & $\begin{array}{c}\text { Você pode me dar outros exemplos } \\
\text { onde você (equipe) explorou as cores } \\
\text { com objetivos estratégicos/ } \\
\text { específicos? }\end{array}$ \\
\hline & 9 - Estratégia & $\begin{array}{l}\text { Você teve ou tem algum objetivo } \\
\text { estratégico especifico ao para/ usar } \\
\text { as cores }\end{array}$ & $\begin{array}{l}\text { Qual tipo de instruções ou objetivos } \\
\text { estratégicos vocé já recebeu ou } \\
\text { recebe dos clientes/ marcas? }\end{array}$ \\
\hline & 10 - Mensuração & $\begin{array}{l}\text { Eles foram alcançados? Como você } \\
\text { mediu o sucesso da cor? } \\
\text { Peça os resultados... }\end{array}$ & $\begin{array}{l}\text { Os objetivos estratégicos foram } \\
\text { alcançados? Quais? A agência / } \\
\text { cliente avaliaram os resultados? } \\
\text { Como? }\end{array}$ \\
\hline \multirow{3}{*}{$\begin{array}{l}\text { EXTRAS: } \\
\text { se tiver } \\
\text { tempo e } \\
\text { abertura }\end{array}$} & $\begin{array}{l}11 \text { - } \\
\text { Concorrência }\end{array}$ & $\begin{array}{l}\text { Você consegue se lembrar de } \\
\text { alguma outra marca que explore } \\
\text { especialmente a cor? E os } \\
\text { concorrentes da [MARCA]? }\end{array}$ & $\begin{array}{l}\text { Você se lembra de alguma marca } \\
\text { que explora a cor de forma especial? }\end{array}$ \\
\hline & $\begin{array}{l}12 \text { - } \\
\text { Especialização }\end{array}$ & \multicolumn{2}{|c|}{$\begin{array}{l}\text { Em sua graduação (especialização / MBA) você teve alguma ou classe sobre } \\
\text { cores? Você acredita que o assunto deve ser [mais] discutido? }\end{array}$} \\
\hline & $\begin{array}{l}13 \text { - } \\
\text { Recomendação }\end{array}$ & \multicolumn{2}{|c|}{$\begin{array}{l}\text { Você poderia me recomendar (ou fazer a ponte) a outros profissionais de } \\
\text { marca e branding para serem entrevistados? }\end{array}$} \\
\hline FIM & & \multicolumn{2}{|c|}{ Despedir-se } \\
\hline
\end{tabular}




\section{Apêndice C: Roteiro das visitas de observação participativa}

\section{• EM RELAÇÃO AO MODO DE SIGNIFICAÇÃO DAS CORES}

$\rightarrow$ Parece que a cor (ou combinação) pertence à marca?

Parece "normal", usual da marca, ou da categoria... ou gera desconforto, ou surpresa?

$\rightarrow$ Quantas cores se sobressaem? Uma, duas, várias? Sente que é muito poluído de cor?

$\rightarrow \quad$ Você gosta das cores/produtos/serviço?

- Prefere alguma?

- Rejeita alguma? Enjoa? As cores são banalizadas? Ou valorizadas?

$\rightarrow$ Os consumidores se aglomeram ao redor de alguma cor específica? (tiram fotos, postam, elogiam, se surpreendem, dão risada, ficam olhando...)

$\rightarrow$ Dá vontade de comprar (pela cor?) Mais de um? Colecionar? Presentear? Lembrou de alguém ou de alguma ocasião por causa da cor?

$\rightarrow$ Do jeito que arranjam os produtos ... te ajuda ou confunde? A cor tem a ver com isso?

$\rightarrow$ Comentários de consumidores sobre as cores? Prestar atenção nas conversas...

$\rightarrow$ CUDADO NA HORA DE TIRAR FOTOS, PRINCIPALMENTE DE CRIANÇAS

\section{- EM RELAÇÃO AO USO DAS CORES}

$\rightarrow$ O quanto a cor (ou combinação) da marca é repetidamente usada?

- Só no logo? Em algum elemento de identificação?

- Na decoração? A ambientação mantém alguma identidade (fixa) cromática)?

$\rightarrow$ Quantas cores são usadas no ambiente?

- Cor-pigmento ou também jogos de luz-cor?

$\rightarrow$ Alguma cor tem destaque especial? É valorizada?

- Alguma é banalizada, muito repetida...

$\rightarrow$ Alguma ativação/promoção na loja que se refere às cores?

$\rightarrow$ Arranjam os produtos em alguma ordem de cor específica? Alternada ou em blocos de cor? 
Impresso em São Paulo, fevereiro de 2018

Escola de Comunicações e Artes | Universidade de São Paulo 